\title{
Estudos sobre um Programa de Reflorestamento Ciliar: subsídios para compreensão das relações entre extensão rural e educação ambiental
}

\author{
Marco Antonio Sampaio Malagodi \\ Engenheiro Agrônomo
}

Orientador: Prof. Dr. MARCOS SORRENTINO

\begin{abstract}
Dissertação apresentada à Escola Superior de Agricultura "Luiz de Queiroz", Universidade de São Paulo, para obtenção do título de Mestre em Ciências - Área de Concentração: Ciências Florestais.
\end{abstract}

\footnotetext{
PIRACICABA

Estado de São Paulo - Brasil

Janeiro - 1999
} 
Dados Internacionais de Catalogação na Publicação (CIP) DIVISĀO DE BIBLIOTECA E DOCUMENTAÇĀO - Campus "Luiz de Queiroz"/USP

Malagodi, Marco Antonio Sampaio

Estudos sobre um Programa de Reflorestamento Ciliar: subsídios para compreensão das relaçōes entre extensāo rural e educaçāo ambiental / Marco Antonio Sampaio Malagodi. - - Piracicaba, 1999.

309 p.

Dissertação (mestrado) - - Escola Superior de Agricultura Luiz de Queiroz, 1998. Bibliografia.

1. Desenvolvimento rural 2. Educação ambiental 3. Extensão rural 4. Mata ciliar 5. Microbacia hidrográfica 6. Reflorestamento I. Título

CDD 634.956 


\section{DEDICATÓRIA}

Ofereço meu trabalho

Ao educador Paulo Freire.

À todos os aprendizes de educadores.

À vocês, Sissa e Franklin.

À toda a minha família. 


\section{AGRADECIMENTOS}

Valeu Xororó (André)! Sem seu apoio e provocações de 95 pra cá, eu não teria conseguido.

Sou muito grato a você Marcos, que me viabilizou um espaço de crescimento pessoal e profissional.

Obrigado pai e mãe.

Queda, agradeço pela inspiração, mas principalmente pela dedicação e seriedade com que você encarou este trabalho, e encara a vida acadêmica. Minha pouca maturidade como pesquisador não conseguiu te desanimar.

Paulo Kageyama, que sua paixão pela conservação continue contagiando outros pesquisadores como eu.

Meu muito obrigado a vocês, Cristina (Cri), Pergoraro, Maciel e Teresa, Adriano, Adriana, Cristina (Lhama), Bárbara, Érica, Ilza, Vitor, Mônica, Reginaldo. Agora já posso ter uma idéia de quantas caras pode ter uma educação ambiental responsável...

Aos novos amigos do Consórcio, que não temeram ser criticados. Essa pesquisa precisou realmente do apoio de vocês. Obrigado Chico, Wagner, Kátia, Regina, Gabriel, Vito, João. Fundamental a colaboração de vocês, da linha de frente: Carlinhos, Evandro e Carrer.

O começo foi difícil, mas vocês facilitaram as coisas pra mim: obrigado Luiz (Gorpo), Fru (Fabiana), Valéria, Maurício, Marysol, Creiza, Gabriela, Jefferson, Margarete, Cláudinha (Caco), Dedé, Renatão (Cachaça), Kátia, Soninha, Lelê, Álvaro, Zé Martins, Olicina, Jefferson, Fátima, Rogério, Tucupi (Edson) e Silvana.

Alguns espaços de estudo e discussão fizeram diferença nessa pós-graduação: meus sinceros agradecimentos ao Núcleo de Apoio à Cultura e Extensão (NACESALQ), ao Projeto UNIR (apesar das deficiências), ao 
FLORESTAS SOCIAIS, à CAMARA, à Associaçăo Golf Boys (AGB), à REDE LATINO-AMERICANA DE EDUCAÇAOO AMBIENTAL, aO MUTIRAO AGROFLORESTAL e ao LABORATÓRIO DE EDUCAÇÅO AMBIENTAL.

Obrigado prof. Luiz Cartos, pela compreensão e apoio iniciais.

Obrigado pela motivaçăo César (CESP), Zeca, Jorge Belix e Giovani (Associaçăo Mata Ciliar, de Pedreira), Nelson, Adriana, Cleide, Hugo, seu Hélio, Giselda e turma da disciplina de Projetos em Educaçăo Ambiental (1997).

Para o dia-a-dia da pesquisa, obrigado Roseli e Mildes (DAAEPiracicaba), Despachante Nené (Capivari), Dr. Vicente (Escritório de Desenvolvimento Rural de Piracicaba), Joăo e Marinho da Casa de Agricultura de Capivari, Márcio (DAEE de Capivari), Márcia Calamaris, Bordignon e Roseli (DEPRN de Campinas), Marcos Ometto (DEPRN de Piracicaba), Dr. Joel (Curador Ambiental de Capivari) e equipe do Serviço Autônomo de Água e Esgoto de Capivari.

Valeu Cláudio, Paula, Ricardo e toda super equipe do xeróx do CALQ que me salvaram na hora...

Em especial, meu agradecimento a vocés, proprietários rurais da microbacia do Ribeirăo Forquilha (Capivari), entrevistados ou apenas contactados. Vocés tém sim, o direito de serem tratados com respeito. 
"Da minha aldeia vejo quanto da terra se pode ver no Universo... Por isso a minha aldeia é tão grande como outra qualquer. Porque sou do tamanho do que vejo e não do tamanho da minha altura..." 


\section{Sumário}

LISTA DE FIGURAS ….......................................................................... viii

LISTA DE TABELAS …..........................................................................

LISTA DE SIGLAS E ABREVIATURAS ............................................. xii

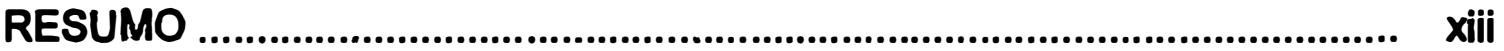

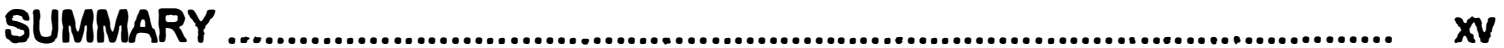

APRESENTAÇÃO ................................................................................. 1

1 INTRODUÇÅO E REVISÅO DE LITERATURA ....................................... 7

1.1 Referenciais para a análise ............................................................... 10

1.1.1 Ambientalismo ......................................................................... 10

1.1.2 Participaçăo, comunicação e cidadania ............................................. 22

1.1.3 Construção do conhecimento ........................................................ 42

1.1.3.1 Revegetação.......................................................................... 46

1.1.3.2 Açăo da mata ciliar na proteção aos recursos hidricos..................... 49

1.1.3.3 Diagnóstico do nível de degradação dos recursos hídricos das 68 bacias dos rios Piracicaba e Capivari.

1.1.3.4 Estratégias de açăo e métodos de trabalho..................................... 75

1.1.4 Projetos ambientais no desenvolvimento rural ................................... 82

1.2 O Consórcio Intermunicipal das Bacias dos rios Piracicaba e Capivari 90 e o contexto do Programa de Reflorestamento Ciliar

1.2.1 Justificativas históricas ................................................................... 90

1.2.2 Organização do Consórcio ............................................................. 92

1.2.3 Diagnósticos da crise dos recursos hídricos..................................... 92

1.2.4 Estrutura do Programa: justificativas ............................................. 98

1.2.5 Avaliaçăo dos resultados ............................................................ 102

1.3 Objetivos da pesquisa.................................................................. 104

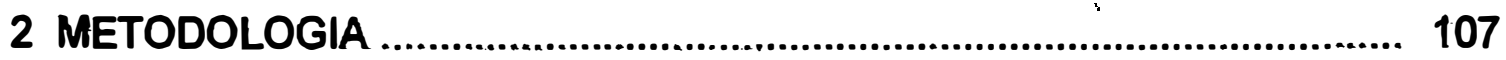

2.1 Aproximaçåo inicial da realidade........................................................ 109 
2.2 Conhecendo a equipe do Consórcio.................................................... 111

2.3 A relaçăo com os proprietários rurais no Forquilha (fevereiro/1998)..... 112

2.4 Os estudos, conversas, reuniões, seminários.................................... 116

2.5 Abordagem com outros atores envolvidos no programa....................... 117

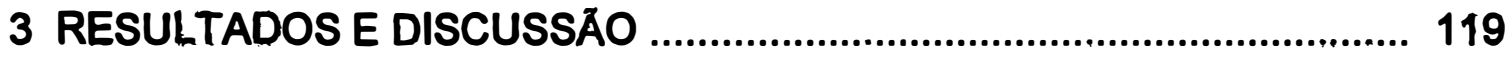

3.1 Considerações iniciais.................................................................. 119

3.1.1 A microbacia do Ribeirão Forquilha (Capivari, SP)............................. 125

3.2 Entrevistas com os proprietários rurais............................................. 137

3.2.1 Caracterização dos entrevistados................................................... 137

3.2.2 Histórico do programa e contexto local.......................................... 140

3.2.3 Estatisticas sobre algumas das opiniozes dos entrevistados................ 145

3.3 Reflorestamentos ciliares: onde se quer chegar? ............................... 152

3.3.1 Responsabilidades.................................................................. 152

3.3.2 A opção do Programa do Consórcio na microbacia do Forquilha........ 158

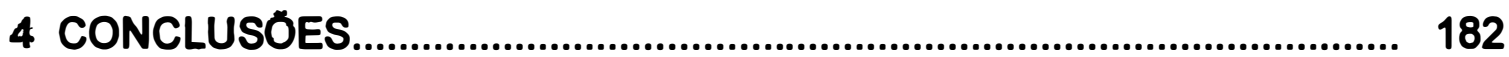

ANEXO A

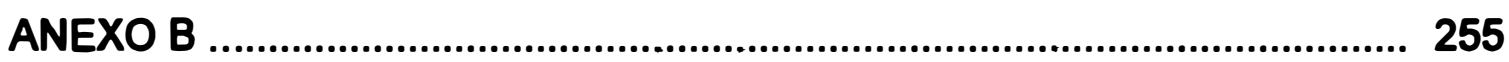

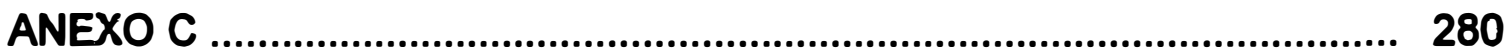

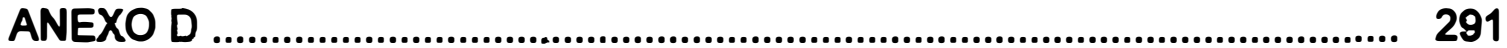

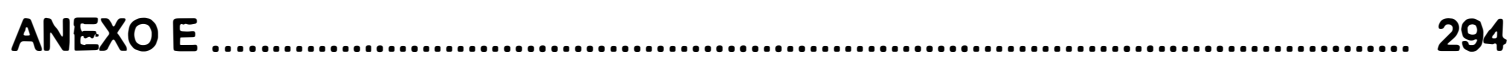

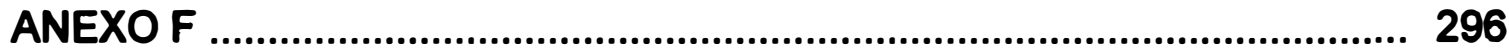

REFERENCIAS BIBLIOGRAFICAS ................................................... 297

BIBLIOGRAFIA CONSULTADA ....................................................... 307 


\section{LISTA DE FIGURAS}

página

1 Evolução do desmatamento no Estado de São Paulo (adaptado de

Vitor et al., 1975).

2 Simplificação de parte de um processo dialógico (baseado em

Freire, 1983).

3 Zona ripária (em verde) e faixa de mata ciliar exigida pelo Código

Florestal (em vermelho), extraído de Zakia (1998).

58

4 Fluxograma de ações do Programa e modelo de Termo de Adesão adotado, adaptado de Ricardo e Romani (1992). 101

5 Localização da microbacia do ribeirão Forquilha (destaque) município de Capivari - e qualidade das águas superficiais nas bacias dos rios Piracicaba e Capivari, adaptado de Consórcio (1998).

6 Microbacia do Ribeirão Forquilha, nas proximidades da cidade de Capivari (SP), com destaque para o formato de algumas propriedades (adaptado dos laudos de vistoria do Consórcio). 127

7 Detalhamento da microbacia do Ribeirão Forquilha, em Capivari (SP): no alto, represa Milhã, em baixo à esquerda o formato de algumas propriedades, no sentido 'cume ao vale'. (adaptado dos laudos de vistoria do Consórcio). 
8 Desempenho geral do Programa e específico para a microbacia do Ribeirão Forquilha (extraído de Consórcio, 1998). Obs.: o título acima compõe a figura original.

9 Área das propriedades na microbacia do Ribeirão Forquilha, em Capivari (SP)

10 Participação (em \%) dos fragmentos vegetais e das matas ciliares na área das propriedades em microbacia do Ribeirão Forquilha em Capivari (SP)

11 Equilíbrio dinâmico e histórico do grau de responsabilidade entre sociedade e indivíduos.

12 Dois caminhos (não excludentes) para se aumentar a responsabilidade do indivíduo para com a sociedade.

13 Análise da estrutura de ação no programa do Consórcio, na microbacia do ribeirão Forquilha em Capivari (SP), na leitura do tempo dos acontecimentos.

14 Análise da estrutura de ação no programa do Consórcio, na microbacia do ribeirão Forquilha em Capivari (SP), na leitura do tempo do planejamento

15 Sugestão de estrutura interpretativa de parte do processo de adoção de inovações tecnológicas.

16 Sugestão de estrutura interpretativa de parte do processo de adoção de árvores na propriedade rural. 
17 Relação de mão-única entre proprietário e agente do

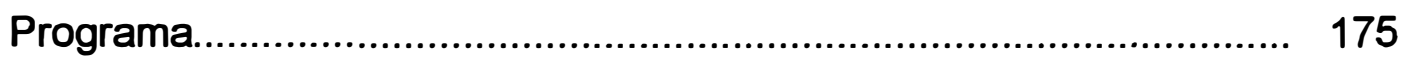

18 Algumas das áreas de conhecimento envolvidas no Programa.......... 176

19 Estrutura orgânica das relações entre as instituições e os proprietários no programa (reapresentando resumidamente as figuras 10 e 14), e mapeamento (por índices) para consulta das entrevistas nos anexos $A$ e $B$. Apenas as instituições em destaque foram parceiras do Programa.......................................................... 180 


\section{LISTA DE TABELAS}

página

1 Descrição de duas das frentes de ação elencadas pelo Consórcio 95 como prioritárias (adaptado de Monticelli \& Barros, 1991)...................

2 A resposta dos proprietários (diferentes categorias de área) frente ao programa.

3 A implantação dos projetos em propriedades de diferentes tamanhos, ao longo dos anos.

4 Importância da implantação de árvores na APP (mata ciliar) quanto à conservação dos recursos hídricos. 


\section{LISTA DE SIGLAS E ABREVIATURAS}

SIGLAS

$\begin{array}{ll}\text { ADEAM } & \text { Associação de Defesa e Educação Ambiental de Maringá } \\ \text { APP } & \begin{array}{l}\text { Área de Preservação Permanente } \\ \text { CATI }\end{array} \\ \begin{array}{l}\text { Coordenadoria de Assistência Técnica Integrada da Secretaria do } \\ \text { Meio Ambiente do Estado de São Paulo }\end{array} \\ \text { CESP } & \text { Companhia Energética de São Paulo } \\ \text { CODASP } & \text { Companhia de Desenvolvimento Agrícola do Estado de São Paulo } \\ \text { CPFL } & \text { Companhia Paulista de Força e Luz } \\ \text { CREA } & \text { Conselho Regional de Engenharia, Arquitetura e Agronomia } \\ \text { DAEE } & \text { Departamento de águas e Energia Elétrica } \\ \text { DEPRN } & \text { Departamento Estadual de Proteção aos Recursos Naturais } \\ \text { ESALQ } & \text { Escola Superior de Agricultura "Luiz de Queiroz" } \\ \text { ETA } & \text { Estação de tratamento de água } \\ \text { ETE } & \text { Estação de tratamento de esgoto } \\ \text { FEHIDRO } & \text { Fundo Estadual de Recursos Hídricos } \\ \text { FF } & \text { Fundação Florestal } \\ \text { IASF } & \text { Indústria Açucareira São Francisco } \\ \text { IBAMA } & \text { Instituto Brasileiro do Meio Ambiente e dos Recursos Naturais } \\ & \text { Renováveis } \\ \text { IF } & \text { Instituto Florestal } \\ \text { INCRA } & \text { Instituto Nacional de Colonização e Reforma Agrária } \\ \text { IPT } & \text { Instituto de Pesquisas Tecnológicas de São Paulo } \\ \text { SAAE } & \text { Serviço Autônomo de Água e Esgoto de Capivari } \\ \text { SABESP } & \text { Companhia de Saneamento Básico do Estado de São Paulo } \\ \text { SENAR } & \text { Serviço Nacional de Aprendizagem Rural } \\ \text { UNIMED } & \text { Sociedade Cooperativa de Serviços Médicos } \\ \text { USP } & \text { Universidade de São Paulo } \\ \text { USP } & \text { Usina União São Paulo } \\ \end{array}$

\section{ABREVIATURAS}

Associação Associação dos Fornecedores de Cana de Capivari

Comitê Comitê das Bacias Hidrográficas dos Rios Piracicaba, Capivari e Jundiaí

Consórcio Consórcio Intermunicipal das Bacias dos Rios Piracicaba e Capivari

Cooperativa Cooperativa dos Fornecedores de Cana de Capivari

Promotoria Promotoria de Justiça/Curadoria Ambiental do Município de Capivari

Sindicato Sindicato Rural (patronal) de Capivari 


\title{
Estudos sobre um Programa de Reflorestamento Ciliar: subsídios para compreensão das relações entre extensão rural e educação ambiental
}

\author{
Autor: MARCO ANTONIO SAMPAIO MALAGODI \\ Orientador: Prof. MARCOS SORRENTINO
}

\section{RESUMO}

O presente trabalho é um estudo de caso sobre o Programa de Reflorestamento Ciliar do Consórcio intermunicipal das Bacias dos Rios Piracicaba e Capivari, desenvolvido na microbacia do Ribeirão Forquilha, em Capivari (SP), a partir de 1992.

Propõe-se a estudar a estrutura do Programa, e o seu desenvolvimento junto aos proprietários rurais.

Analisou-se o programa segundo o modo como diagnosticou a crise dos recursos hídricos e planejou ações, o modo como trabalhou o conhecimento científico e a legislação ambiental, o modo como atribuiu ao reflorestamento ciliar papel prioritário na conservação dos recursos hídricos da microbacia e finalmente, segundo o modo como implementou os modelos de reflorestamento para a realidade da microbacia. Tal estudo se pretende também incentivador das crescentes discussões em torno da necessidade de aperfeiçoamento da legislação florestal e agrícola, e das estratégias de incentivo à adoção de essências florestais junto aos proprietários rurais, trazendo na reflexão sobre as várias etapas de desenvolvimento dos programas (elaboração, articulação das parcerias, busca de recursos, treinamento dos técnicos, identificação dos benefícios esperados no programa, abordagem junto ao proprietário, avaliações periódicas) oportunidades valiosas de construção de 
conhecimentos que podem ser úteis no delineamento de projetos educacionais voltados à temática ambiental e de extensão rural.

Chega-se à conclusão que o efetivo resgate/manutenção da qualidade ambiental no meio rural deve incluir o resgate/manutenção das responsabilidades mútuas entre proprietários e instituiçōes que atuam no meio rural, concretizando-se em ações e políticas integradas que tomem o desenvolvimento humano como seu alvo principal. Substituir a visão de que são potenciais degradadores do ambiente, por percebê-los como potenciais zeladores da qualidade ambiental, e superar a concepção de que efetuar plantios de árvores no chão - pelo só efeito desta ação - significa conservar os recursos hídricos, é pré-requisito básico para a construção de processos educacionais voltados ao reflorestamento ciliar. 


\title{
STUDIES ABOUT A RIPARIAN AFORESTATION PROGRAM: SUBSIDIES TO UNDERSTANDING RELATIONSHIPS BETWEEN RURAL EXTENSION AND ENVIRONMENTAL EDUCATION
}

\author{
Author: MARCO ANTONIO SAMPAIO MALAGODI \\ Orienting: Prof. MARCOS SORRENTINO
}

\section{SUMMARY}

This work is an study of case about the Riparian Aforestation Program of the Consórcio Intermunicipal das Bacias dos Rios Piracicaba e Capivari, developed at Forquilha Stream watershed, on Capivari (SP), since 1992.

It wants to study the Program structure, and his development with the rural owners.

The program was analysed through the way it understood and plan actions on water resources crisis, the way that it manage the scientific knowledge and the environmental laws, the way that it attributes main role to riparian reforestation at water resources conservation on watershed context, and finally, the way it implemented the aforestation models to the watershed reality. This study, also, wants itself encouraging the crescent discussions about the necessity of forestry and agricultural laws improvement, but also, the improvement of forest species adoption encourage strategies, bringing in this reflection about the several stages of programs development (creation, partnership articulations, search of resources, technical team training, the program expected benefits identification, the approach with owners, periodical evaluations) important opportunities of knowledge constructions, that may be 
useful on educational programs plans, on environment issues and rural extension context.

We conclude that rural environmental quality recovery/conservation must include the recovery/conservation of the responsibilities between owners and public institutions that work at rural context, growing in order to materialise integrated actions e policies that see human development as the main target. Fundamental to construct riparian reforest educational actions is to replace the concept that see them just as quality environment potential destroyer by the environment quality potential janitors concept, and to exceed the poor idea that we really can conserve water resources only by planting trees. 


\section{Apresentação}

Numa conversa com um técnico da CESP de Primavera (SP), em 96, ele me apresentava sua ansiedade por ferramentas na área educacional, para o seu trabalho de campo (fomento florestal) junto aos proprietários, de modo a melhorar sua comunicação com eles, elevando seu nível de participação. Mas minha leitura de alguns documentos e encontros internacionais sobre educação ambiental (alguns com mais de 20 anos), estava ainda distante da realidade prática cotidiana que me fora colocada. Assim também minha leitura dos textos do educador Paulo Freire, um dos provocadores dessa dissertação.

De volta à minha realidade regional (bacia dos rios Piracicaba e Capivari), perguntava-me como as instituições públicas, entidades da sociedade civil estavam enfrentando ou preparando-se para enfrentar o quadro alarmante, segundo alguns - de degradação ambiental (com destaque para a degradação dos recursos hídricos)?

Como é diagnosticado o problema? Quem o faz? Como são eleitas e executadas as ações prioritárias? Como estão organizadas as instituições que assumiram tal responsabilidade? Como é trabalhada a legislação ambiental? Como se dá a comunicação com a população? Qual seu nivel de envolvimento/participação nesse contexto?

Posturas autoritárias; improvisos; simplificações que fogem da realidade, mas que viabilizam praticidade; engenharia das articulações políticas. É parte do ambiente concreto em que tenho trabalhado ao longo dessa pesquisa. Quase sempre me foram colocadas justificativas para tais 'estilos', tentando me 'sensibilizar' de que, nesse país, ainda é assim que se resolvem as coisas: na coerção. $E$ quanto maior o impacto no bolso das pessoas, maior o poder da proposta/ação. 
Isso reforçou minha vontade de pesquisar o campo da educação de adultos, de famoso desprestígio, que me lembre, desde minha infância: "ele não aprende, não tem jeito... eu já expliquei tantas vezes"; "adulto não tem jeito... tem que ensinar quando ainda é criança". O campo da educação ambiental despontava pra mim, então, como aquele que poderia me balizar nessa busca.

Interessado na reflexão sobre desenvolvimento rural sustentável, aproximei-me de dois dos aspectos legais que deveriam contribuir para a conservação e o equilíbrio do ambiente rural: a área de reserva legal e a área de preservação permanente (onde estão incluídas as matas ciliares). Escolhi o enfoque voltado à mata ciliar, pois envolve-a várias dimensões, tais como: sócio-econômicas; culturais; de uso e ocupação do solo; restrições legais à exploração; técnicas de revegetação. Pensando inicialmente em conhecer os fatores que poderiam levar o proprietário a plantar tais matas, com 0 desenvolvimento da pesquisa, fui sentindo maior relevância no estudo das relações entre os técnicos (em nome de seus programas, projetos, instituições) e os proprietários rurais. Isso poderia trazer à tona uma reflexão potencialmente esclarecedora da estrutura de ações (como os reflorestamentos ciliares) de motivação conservacionista: a qualidade do processo comunicativo.

Ainda no início do mestrado, quando conheci a análise que Freire (1983) faz do trabalho do agrônomo como educador, opondo à extensão a comunicação, não pude deixar de lembrar das dificuldades vividas durante minha formação - em engenharia agronômica - aqui na ESALQ, aprendendo a vender 'pacotes tecnológicos'. Foi o tempo da grande 'aula prática' sobre o papel da universidade no processo de construção do conhecimento (e consequentemente, sua influência no desenvolvimento da sociedade), ainda que não fizesse o menor sentido com o meu próprio processo de aprendizagem até então, nem tão pouco com meus sonhos de atuação profissional, junto aos agricultores e agricultoras. 
Um dos aspectos que mais me provocam no trabalho de Freire, é o entendimento do processo de comunicação na 'Prática da Liberdade' (Freire, 1983) é como um espaço que se cria para compartilhar determinado poder, ou para permitir que tal compartilhamento um dia ocorra. A ausência dessa dimensão ainda está muito viva na minha história familiar, escolar, afetiva... assim como na do País, onde tal fato se repete (ou se reflete), mantendo muitas similaridades. Sim, estou falando de autoritarismo, de machismo, de preconceito, de presunção, de coerção - herança familiar ou histórica que atinge a todos nós, em algum grau. No campo profissional, tenho percebido que tal postura esbarra no campo dos direitos humanos, dos valores da democracia, dos princípios da cidadania, da ética, ou mesmo do fracasso metodológico, quando existem pretensões à participação da comunidade. No contexto do desenvolvimento rural brasileiro, os reflexos de tais posturas podem ser avaliados pelos impactos sócio-ambientais de certas políticas, como na chamada 'revolução verde' - retratados por Amstalden (1991) -, nos quais a ESALQ teve grande contribuição.

É nesse contexto que busco no campo educacional, subsídios que auxiliem na visualização de caminhos de (re)construção da sociedade, que necessariamente se estruturem a partir da comunicação (relação dialógica), esta entendida no contexto desse trabalho como um fenômeno de troca entre aprendizes (que o são realmente, em diferentes graus e contextos), ambos em busca da construção de conhecimento, que pressupõe uma predisposição para o compartilhamento do poder e um respeito mútuo.

Vencer aquela minha formação disciplinar, pulando entre os tais 'feudos' departamentais, tornou-se um considerável desafio à construção dessa dissertação, que exigiu estudos em outras áreas de conhecimento reflorestamento com essências nativas, legislação ambiental, administração pública, dinâmica dos recursos hídricos, da análise integrada em bacias hidrográficas, articulações políticas estratégicas, efetivação de planos de ação, entre outros. Desafio, não só pela falta de conhecimento específico, mas pelo 
despreparo na análise simultânea de tantos fatores que na realidade, fazem parte de um único processo. Nesse aspecto, compartilho tal despreparo, com as universidades, os órgãos públicos, e coordenadores de programas ambientais, que também vêm de formações similares e condições de trabalho precários. Acredito que 0 abismo entre tais temas esteja intimamente relacionado ao abismo entre as pessoas, como ficou claro pra mim no desenvolvimento desta pesquisa.

Por tudo isso, desde o começo temi o risco de retratar uma realidade complexa de forma enviesada pela minha pouca maturidade, ao mesmo tempo em que desejei muito trilhar esse novo caminho, necessário à busca de respostas às tais perguntas, mas também coerente com a própria razão de existir do mestrado, frente às deficiências encontradas na graduação. Minha maior expectativa é conseguir provocar uma reflexão, no sentido de rever alguns aspectos que nos passam despercebidos no dia-a-dia da atuação profissional, principalmente no potencial transformador que eu acredito existir na participação do cidadão comum, seja na conservação ambiental, seja no desenvolvimento rural e no progresso da ciência.

A abertura e apoio dos meus colaboradores (colegas, professores, Consórcio, técnicos, agricultores) nesse estudo, geraram em mim um tal movimento nas idéias, transformando minha leitura das atuais ações institucionais (voltadas ao resgate da qualidade ambiental) de pessimista a otimista. Devolveram-me a crença de que um trabalho integrado, ainda que construído entre diferentes, pode realmente contribuir na reversão do histórico processo de alienação da autonomia das pessoas e de seus sonhos frente à própria vida, e a conseqüente degradação ambiental - que aqui não leio senão como sintoma cujo tratamento é ineficaz (embora pareça eficiente). Adquiri tal otimismo não pelo cenário estudado, de coerção dentro de uma ação ambiental e da conseqüente revolta de alguns proprietários, mas por vislumbrar a possibilidade de transformação dessas ações isoladas para projetos interdisciplinares e integrados, que prezem por acordos legítimos dentro de um 
contexto mais profundo de participação social. Curiosamente, as pessoas são ao mesmo tempo (no seu modo de conhecer e agir) o problema e a esperança de solução.

No desenvolvimento da pesquisa, conheci diferentes contextos, motivações e dificuldades, que me obrigaram a algumas ponderações, dentro da coerência que exigiam meus próprios referenciais teóricos. Esse amadurecendo permitiu a devida cautela frente aos caminhos que inicialmente pareciam-me mais fáceis: a promoção dos trabalhos desenvolvidos pelo Consórcio, ou a defesa radical dos pequenos/médios produtores atingidos pelo programa, ou a dura crítica à desestruturação dos órgão públicos regionais como Casa da Agricultura, DEPRN, Fundação Florestal, Prefeituras... Desse modo, me ative à análise específica dos aspectos relativos ao programa estudado, e baseado no discurso dos técnicos à frente de tais instituições, objetivando um retrato dos últimos anos apenas, tendo por cenário a problemática ambiental (degradação dos recursos hídricos, escassez de cobertura florestal nativa ou exótica, pressão da sociedade pelo fim da queimada da cana, dentre outros), a reestruturação da administração pública (descentralização, municipalização) e o gerenciamento dos recursos hídricos (sistemas de gestão que pretendem-se integrados, descentralizados e participativos).

Faltava então a escolha da área. Busquei-a junto ao Programa de Reflorestamento Ciliar do Consórcio Intermunicipal das Bacias dos Rios Piracicaba e Capivari, que teve início em 91, nos municípios de Capivari, Nova Odessa e Sumaré, mas que hoje se estende por mais 9 municípios (Americana, Artur Nogueira, Atibaia, Bom Jesus dos Perdões, Capivari, Cordeirópolis, Piracaia, Saltinho e Valinhos). Após uma primeira análise do material publicado pelo Consórcio, dos laudos de vistoria realizados em parceria com o DEPRN, e de entrevistas realizadas com os técnicos de campo locais dos três municípios, optei pela microbacia do Ribeirão Forquilha, em Capivari, por um conjunto de características que julguei interessantes ao trabalho: idade e pioneirismo do 
programa (o primeiro realizado pelo Consórcio, juntamente com Sumaré e Nova Odessa), o contexto sócio econômico da exploraçăo canavieira (que representa também grande parte da bacia do rio Piracicaba), a heterogeneidade da estrutura fundiária (propriedades com área desde 7 a 1200 ha), proximidade de Piracicaba, destaque para a atuaçăo do Promotor de Justiça de Capivari na efetivaçăo dos plantios, e a continuidade das açōes em nivel de promotoria até o presente (1998).

Inicialmente me interessei pelos trabalhos de educaçăo ambiental que o Consórcio vinha desenvolvendo através do Programa Semana da Água, junto às delegacias de ensino, professores e os próprios alunos da rede de ensino. Fui informado de que o trabalho na frente de proteçăo aos mananciais (a frente aqui estudada) nunca tivera pretensões de ser educativo, o que dificultava uma avaliaçăo nesse aspecto, como eu buscava. Passei entáo a conhecer os variados aspectos desse programa, atento ainda à qualidade do processo comunicativo: qual seria sua importância nesse contexto, as possiveis consequêencias... de modo a compreender como um enfoque educativo poderia contribuir em tais açóes. A própria necessidade de aprofundamento nos temas que se mostravam importantes para uma compreensăo global do contexto, guiaram as etapas seguintes, a metodologia, a bibliografia.

Este trabalho está assim estruturado. Os temas relevantes à pesquisa estáo resumidamente apresentados no capítulo 1, Introduçăo $\theta$ Revisăo de Literatura. Ainda nesse capitulo, apresento o Consórcio e os objetivos desta pesquisa.

Descrevo todas as etapas de construção da pesquisa no capítulo 2, Metodologia, agrupando os roteiros das entrevistas no Anexo C. Apresento o estudo mais aprofundado do programa de reflorestamento ciliar do Consórcio no capitulo 3, Resultados e Discussăo, onde apenas indico e mapeio as entrevistas (principal fonte de dados), apresentando-as nos Anexos $A$ e $B$, procedendo a apresentaçăo dos resultados tabulados e analisados. Finalizo com as Conclusóes, quando levanto a necessidade de outros estudos. 


\section{Introdução e Revisão de Literatura}

Em março de 97, tive a oportunidade de participar de um evento que, embora não diretamente relacionado com o recorte realizado nesta pesquisa, ajudou-me a entender o conceito de educação mais difundido regionalmente.

Foi durante o lançamento de um programa de educação ambiental em Limeira (no Horto Florestal), acompanhando um técnico do Consórcio", quando pude presenciar ${ }^{2}$ a seguinte discussão quanto à escolha da metodologia e objetivos da ação:

"(...) quais os objetivos do processo? (Precisamos) ${ }^{3}$ Definir se vai ter uma ação corretiva, ou vai ser uma ação somente educacional, onde, pelo que eu tô sentindo aqui é mais educacional. É passar uma cultura de conservacionismo, de conservação do meio ambiente, pra população e pra comunidade. Eu acho que esses dois caminhos precisam estar primeiramente bem definidos. Porque se for uma ação corretiva, junto com uma ação educacional, realmente precisa ser dividido; pegar as pessoas técnicas e as pessoas de educação. Eu acho que o primeiro passo é definir bem esses dois caminhos, no grupo, pra poder aí... traçar os objetivos, as metas (representante da Polícia Florestal de Limeira).

$\mathrm{Na}$ seqüência, apoiando a colocação anterior, argumenta a representante da empresa Águas de Limeira (ex-funcionária do SAAE - Serviço Autônomo de Água e Esgoto de Limeira):

"(...) a gente já sabe que a educação ambiental em primeiro lugar, mas uma ação corretiva, como ele propôs, realmente se toma necessária. (...)

\footnotetext{
${ }_{2}^{1}$ Coordenador do programa de educação ambiental Semana da Água.

2 Junto ao grupo formado por representantes da Polícia Florestal, do serviço de água e esgoto de Limeira - Águas de Limeira, da Imprensa, da Delegacia de Ensino, da CESET, da CETESB, da FIESP, da UNICAMP, da Prefeitura, do Sindicato Rural, do Consórcio, de ONGs, entre outros.
} 
Qual é a ação que a gente quer? Nós queremos uma ação preventiva, uma ação educativa, e queremos uma ação corretiva imediata. Nós estamos lançando um programa que, no meu ver, que tem esse objetivo: amplo. Então nós temos que detectar quais são as áreas, de maior emergência, pra ir lá e trabalhar com a ação corretiva. Detectar quais são as áreas que investindo numa conscientização, numa prevenção, você vai ter resultados, e quais as áreas que trabalhando a questão educacional, você vai ter resultados mais pra frente. Porque um programa... esses programas só têm sucesso se forem enxergados dessa maneira."

O coordenador do Consórcio me explicava, depois da reunião, a importância que teve a participação de cada uma das instituições presentes, na estratégia de envolvimento e amarração política para que tanto as discussões (nos sub-grupos temáticos que seriam futuramente formados) como as intervenções futuras fossem praticáveis. As afinidades, as desavenças, a hierarquia do poder de decisão entre as secretarias municipais, o cuidado na composição e delegação de funções para a maior credibilidade e chance de atrair recursos, a consideração pela fala de todos criando um espaço agradável de participação, imprescindivel à operacionalização do programa..., entre outros aspectos.

Desse contexto se destacam alguns aspectos fundamentais pra compreensão do papel da educação no resgate da qualidade ambiental, que tento traduzir em perguntas, tais como:

- O que se entende hoje (no contexto da atuação do Consórcio e de seus parceiros) como ação educacional frente ao ambiente?

- Como esta se relaciona com a tal 'necessidade de ação corretiva'?

- É possivel passar uma cultura de consenação do ambiente?

- O que está por trás de comportamentos (muitas vezes nossos próprios) que consideramos irresponsáveis, frente à conservação ambiental?

\footnotetext{
${ }^{3}$ Nas citações das entrevistas as palavras indicadas entre parêntesis são minhas, introduzidas para facilitar a compreensão da transcrição.
} 
- Como atuar nesse delicado jogo de estratégias que é a articulação política?

- Como enfrentar a complexa problemática ambiental sem tal articulação?

- Como promover a participação da comunidade - tanto das instituições que os representa, na criação de um programa, como das pessoas nas ações concretas desse programa - na transformação da realidade local? 


\subsection{Referenciais para a análise}

\subsubsection{Ambientalismo}

"A crise ambiental (pensada inclusive sem catastrofismos) não tem alternativas realistas fora de um ambientalismo sustentado em uma ética complexa e multidimensional que recupere 0 sentido da fraternidade, o sentido espiritual da vida social e natural. A modernidade trocou a visão orgânica e transcendente do mundo clássico e medieval por uma visão dirigida apenas para a autopreservação. Porém o relativismo ético e empírico inerente às políticas orientadas com esse fim não parece ter contribuído muito para garanti-la. A necessidade de desfazer a inversão moderna, representada pela emergência e evolução de um ambientalismo multissetorial global de forte raiz ética e espiritual, deriva do caráter civilizatório da crise ambiental, afetando todas as dimensões da condição humana. A crise ambiental não é apenas um resultado indesejado e conjuntural, é um desencontro dos mortais com suas raízes. Raízes que se revelam nas perguntas ancestrais dos seres humanos" (Leis,1996: p. 120).

Os pensamentos e ações na conservação e resgate da qualidade ambiental que se desenvolvem em nossa região, ainda que possam não representar escolhas conscientes por este ou aquele caminho ideológico, filosófico, não podem ser dissociados do contexto histórico global de onde se formaram, que é econômico, cultural, social, espiritual, etc. Pelas próprias características de cada processo histórico, podemos perceber hoje, as cicatrizes correspondentes, fruto da diversidade de concepções, crenças e formas de se organizar que as diversas sociedades têm expressado através da sua cultura, que é resultado da ação humana no meio. E este está sempre em transformação, pois assim são os seres humanos, e claro, a natureza. Assim, tanto na bacia Amazônica como na bacia do Nilo, ou do Ribeirão Forquilha (em Capivari), o contexto ambiental local (em sentido amplo) desafia seus 
espectadores a entenderem o contexto histórico-evolutivo das sociedades que lá viveram, e vivem ainda hoje. Por exemplo, os atuais uso e ocupação dos solos paulistas estão intimamente relacionados à crescente urbanização, à demanda dos mercados consumidores, à industrialização, às políticas agrícolas, às condições edafo-climáticas, à tradição das famílias dos proprietários por esta ou aquela atividade, etc. Antes destes fatores (que os influenciaram diretamente), ainda, estão os 'ciclos' econômicos das grandes plantations, como a cana, o café e o algodão, que deixaram suas marcas em nossa cultura, economia, política, e também em nossos recursos naturais, imprimindo uma forma de organização social.

Anterior a estes, estava o desafio de desbravar o território selvagem, retirando a cobertura vegetal nativa (florestas, cerrados, campos), abrindo picadas, construindo vilas, aprisionando e assassinando indígenas. Enfim, tomando posse do 'novo território' da Coroa Portuguesa, aqui nas Américas.

Assim também, o sentimento de proteção à natureza, a percepção da necessidade de protegê-la ou de manejá-la de maneira sustentável, refletem o momento em que cada povo, sociedade, comunidade, aldeia, vivem. Suas ações, claro, são concretizadas dentro desse mesmo contexto.

Se, então, estamos procurando enfocar de modo crítico tanto o programa desenvolvido pelo Consórcio, quanto o quadro desconcertante de degradação dos recursos hídricos nas bacias dos rios Piracicaba e Capivari, como entendê-los historicamente?

Vamos arriscar, aqui, uma simplificação de alguns fatos que nos parecem ser mais característicos para a compreensão do contexto que queremos desenvolver.

A partir da década de 70 , a grande região de Campinas começa a se industrializar e urbanizar a taxas crescentes, favorecida por políticas nacionais. Cresce muito o consumo de água dessas regiões, assim como os despejos de poluentes (esgoto doméstico e resíduos industriais), que recebem 
pouco ou nenhum tratamento (São Paulo, 1994). Não há a motivação para se tratar o recurso hídrico que se libera (à jusante), além da necessidade de tratamento daquele que irá se consumir (à montante). A estratégia passa a ser então a construção de pequenas barragens e reservatórios, visando o abastecimento de água e fornecimento de energia elétrica. Como a qualidade dessa água também não é satisfatória ao consumo humano, e os custos de seu tratamento considerados inviáveis, as administrações municipais passam a construir pequenos açudes e represas em suas periferias (área rural) onde os recursos hídricos ainda podem ser obtidos com boa ou razoável qualidade (São Paulo, 1994).

Tais mananciais foram, então, sendo escolhidos e represados ao longo dos anos, como forma mais adequada e econômica, para as cidades que compõe a bacia do rio Piracicaba, uma vez que os principais cursos d'água já estavam em avançado grau de degradação, principalmente devido à quase total ausência de tratamento de esgotos domésticos (apenas $4 \%$ de remoção de toda a carga poluidora urbana) e à redução insatisfatória das cargas poluidoras industriais ${ }^{1}$, principalmente na área da bacia que sofre crescente processo de conurbação² (São Paulo, 1994).

Crescem as manifestações de movimentos ambientalistas pela limpeza dos rios (Sebastianes, 1992). Crescem os custos do tratamento das águas (Ricardo \& Romani, 1991). Crescem as populações dos centros urbanos (São Paulo, 1994). Iniciam-se algumas ações no Ministério Público contra algumas prefeituras que despejam seus esgotos in natura no rio, e as crescentes disputas (intermunicipais) pelos recursos hídricos ${ }^{3}$. Diante das

1 Segundo o relatório, os indices de redução dos ramos industriais (considerando apenas cargas poluidoras de origem orgânica) de alimentos (40\%), têxtil (67\%), bebidas (68\%), aguardente $(46,4 \%)$ e tinturaria $(15,4 \%)$ estão bem abaixo dos $80 \%$ previstos na legislação. Isto de deveria ao fato de que muitas indústrias "possuem sistemas inadequados ou insuficientes de controle de poluição", a exemplo do que ocorre nos compartimentos ambientais da sub-bacia do Piracicaba (São Paulo, 1994).

${ }^{2}$ Processo onde a expansão das cidades passa a configurar uma única área metropolitana.

3 ANTONIAZZI, V. H. (Prefeito de Valinhos e Presidente do Consórcio, gestão 97/98, Valinhos/ SP). Comunicação pessoal, durante palestra de abertura de uma etapa prática do Treinamento 
previsões de "caos" no abastecimento de água nessas bacias, para um futuro bem próximo (estimado pelos técnicos do Consórcio para 2010), dos crescentes processos sobre as prefeituras no Ministério Público, e da escassez de recursos para execução das tardias obras de saneamento (tratamento de água e esgoto, destinação do lixo), algumas prefeituras decidem se unir e criar um Consórcio Intermunicipal, suprapartidário e que transcende os mandatos das administrações públicas, capaz de elaborar projetos e atrair os recursos (externos e internos) necessários às obras. Uma das ações prioritárias desse Consórcio de Municípios ("consórcio de poluidores", como lembra seu coordenador geral ${ }^{4}$ ) é a proteção daqueles mananciais de uso público, através do reflorestamento ciliar (Ricardo \& Romani, 1991).

Frente à escassez de recursos e necessidade de rapidez de resultados, decide-se por uma estratégia de trabalho na base da coerção, pela força da lei, enxergando nos proprietários rurais que não possuem suas matas ciliares conservadas (independentemente da época ou contexto em que foram retiradas) os degradadores do recurso hídrico que sobrou. Não que esse recurso já esteja se degradando (pois não existem até hoje informações a esse respeito, segundo a equipe do $\mathrm{SAAE}^{5}$ de Capivari), mas os custos de se fazer tal proteção agora são muito menores do que a perspectiva de tratá-lo amanhã. Desenvolve-se, assim, um trabalho que obriga a participação dos proprietários, caracterizando-se pela estrutura de comunicados que não contribuem para a organização local, nem para a visualização da relação entre essas medidas e a possível melhoria da qualidade de vida dos moradores daquela microbacia, unidade da ação da recomposição ciliar.

A luta do Consórcio pela conservação dos recursos hídricos através da estratégia dos reflorestamentos ciliares corre, assim, o risco de não

para Capacitação de Coordenadores e Professores Aplicadores do Programa de Educação Ambiental "Semana da Água". 1997.

${ }^{4}$ Ver entrevista, no Anexo $B$.

5 Serviço Autônomo de Água e Esgoto de Capivari (SP). Entrevista no Anexo B. 
ganhar apoiadores. Onde haveria, dentro desse quadro, lugar para o envolvimento espontâneo dos proprietários ${ }^{6}$, para o desenvolvimento de abordagens comunicativas ${ }^{7}$, para fortalecimento das organizaçōes locais para a ação, para o resgate do papel das instituições de assistência, para as pesquisas direcionadas à realidade local? Onde caberia 0 tal do desenvolvimento humano, preconizado pelo $\mathrm{ONU}^{8}$, ou a idéia de que "o manejo e a produção de conhecimento constituem a mais decisiva oportunidade de desenvolvimento" para uma nação? (Demo, 1994).

$\mathrm{Ou}$, tais preocupações não teriam importância no contexto da degradação ambiental pela qual estão passando nossas bacias hidrográficas?

Voltando-nos para a análise que Leis (1996) desenvolve em seu livro "O Labirinto - ensaios sobre ambientalismo e globalização", tentaremos situar algumas dessas questões no contexto nacional e mundial.

Nas últimas décadas, a população mundial vem percebendo a intensificação dos problemas sócio-ambientais globais. A preocupação pública, segundo o autor, vem crescendo desde a década de 60 com o que chama de 'revolução ambiental norte-americana'; chega ao Canadá, Europa Ocidental, Japão, Nova Zelândia, Austrália na década de 70, e na década de 80 atinge a América Latina, Europa Oriental, União Soviética e Sul e Leste da Ásia. Surgem novos atores (ongs, grupos comunitários, agências estatais federais, estaduais e municipais, instituições científicas, administradores e gerentes com novo perfil, mercado consumidor verde, agências e tratados internacionais).

\footnotetext{
${ }^{6}$ Princípio básico do Sistema Estadual de Recursos Hidricos, indicado em São Paulo (1994), e termo que gerou polêmica entre o discurso dos coordenadores do Programa e os depoimentos dos proprietários rurais.

${ }^{7}$ Como a que é encontrada nas bases pedagógicas do programa Semana da Água, também desenvolvido pela Secretaria Executiva do Consórcio (Monticelli et al., 1996). Segundo o artigo, tal programa preconiza uma Proposta Construtivista Sócio-Interacionista.

${ }^{8} \mathrm{Na}$ Conferência de Viena sobre Direitos Humanos da ONU, em junho de 1993, ficou definido o desenvolvimento humano como direito, ressaltando o papel da cidadania (Demo, 1994).
} 
"O ambientalismo surgido como um movimento reduzido de pessoas, grupos e associações preocupados com o meio ambiente transforma-se num ramificado movimento multissetorial".(Leis, 1996: p. 91)

Leis (1996) descreve o processo de consolidação do ambientalismo, que como movimento histórico internacional, em relação à sua dimensão política, distinguiriam-se duas posições básicas:

1) Uma minoritária: caracterizada por atitudes éticas e espirituais de tendência biocêntrica (considerada fora da dimensão política);

2) Uma majoritária: que assume a dimensão política. Ainda dentro desta posição, poderíamos encontrar: a) uma minoria radical, que luta pela disseminação rápida e intensa de valores ecológicos e drástica redistribuição do poder político e econômico; b) e uma maioria reformista, que considera necessária a adoção gradual de um novo modelo de desenvolvimento que interiorize a sustentabilidade social e ambiental, criandose os devidos mecanismos.

Para a nossa busca, interessa a análise que o autor desenvolve em torno das diferentes versões de desenvolvimento sustentável existentes, pois estas, orientam as diversas alternativas e opções dos atores envolvidos. Classifica as versões de desenvolvimento sustentável em 3 categorias: estatista, comunitária e de mercado.

a) estatista: considera que a qualidade ambiental é um bem público que somente pode ser resguardado eficientemente através de uma incisiva intervenção normativa, reguladora e promotora do Estado. Confia em mecanismos de comando e controle, mas também de mercado (como licenças de poluição comercializáveis, taxas de depleção de recursos naturais e tarifas). Influência das políticas e agências ambientais européias e americana que nascem nas últimas décadas.

É fácil a visualização desta categoria no atual cenário de gerenciamento dos recursos hídricos nas bacias dos rios Piracicaba, Capivari e Jundiaí pelos Comitês e Agências de Bacias, onde se negociam outorgas pelo 
uso da água, licenças, e em breve a cobrança pelo uso da água, e a aplicação do princípio poluidor-pagador. A inspiração vem principalmente da experiência francesa (modelo desenvolvido na bacia do Sena-Normandia)

b) Comunitária: considera que as organizações de base da sociedade devem ter um papel predominante na transição para uma sociedade sustentável. Desconfia do mercado e do Estado como alocadores de recursos; ambos deveriam preencher um papel subordinado ao poder da sociedade civil. Prioriza claramente o princípio da equidade social em detrimento da eficiência alocativa. Um exemplo seriam as Ongs do terceiro mundo.

c) De mercado: acredita que se pode avançar eficientemente na direção de uma sociedade sustentável por meio da lógica do mercado (com significativa apropriação privada dos recursos naturais e da expansão dos consumidores verdes. "(...) os produtores protegerão o ambiente quando isso seja demandado pelos consumidores". Prioriza o princípio da eficiência alocativa em detrimento da equidade social, devendo existir mecanismos estatais reguladores e a atuação educativa de Ongs, ambos numa posição subordinada aos mecanismos do mercado.

Para McCormick (1992), "O movimento não começou num país para depois espalhar-se em outro; emergiu em lugares diferentes, em tempos diferentes e geralmente por motivos diferentes" (p.21).

No Brasil, Leis nos diz que os primeiros antecedentes do ambientalismo são essencialmente preservacionistas, como em 1958, quando da criação da Fundação Brasileira para a Conservação da Natureza. A maior violência do processo de 'modernização' brasileira, na década de 70 , teria criado um maior espaço de atenção à questão ambiental, em relação aos nossos vizinhos latino-americanos. O ambientalismo brasileiro nesse período, se caracterizaria como movimento bissetorial: as associações ambientalistas e as agências estatais, que desenvolvem "relação simultaneamente complementar e contraditória, confluindo ambos na definição da problemática 
ambiental recortada pelo controle da poluição urbano-industrial e agrária e pela preservação dos ecossistemas naturais."

Silva (1992) considera que a formação do movimento ecológico brasileiro formou-se a partir de 1974, "quando por um processo de distensão política começam a surgir manifestações de discórdia sobre o estilo de desenvolvimento adotado pelos governos militares" (p.111).

Sob influência norte-americana e européia, as associações ambientalistas brasileiras constituem-se no enfrentamento de temas como o "questionamento da civilização urbano-industrial pelos seus impactos devastadores sobre a natureza, promoção da ecologia como ciência da sobrevivência e de uma nova ética ecológica, combate à poluição causada por indústrias e veículos e à destruição das belezas paisagísticas causada por empreendimentos humanos, luta contra o uso exagerado da mecanização agrária e contra o uso indiscriminado de agrotóxicos, preservação da flora e da fauna nativas" (Leis, 1996). O autor critica, porém, a não abordagem, aqui, dos problemas do crescimento populacional e do uso conservacionista dos recursos naturais, contempladas internacionalmente.

Segundo o autor, a recepção da problemática ambiental por parte das entidades brasileiras foi bastante acrítica, no contexto da forte influência inicial que sofreu do movimento ambientalista norie-americano e europeu:

"(...) elas não perceberam a especificidade da deterioração ambiental brasileira em relação ao evidente déficit de saneamento básico (essa questão não estava incluída no programa ambientalista do Primeiro Mundo porque tinha sido resolvida previamente)" (Leis, 1996: ps. 97 e 98).

Minc (1985) ressalta, porém, as diferenças de características da questão ecológica no Brasil e nos "países do mundo desenvolvido", abordando a questão da cidadania:

"Aqui a questão ecológica se entrelaça com um drama de exploração e de miséria em grande parte desconhecidos dos países ricos. As legislações de proteção ambiental existentes no Brasil são mais recentes, em muitos 
casos menos rígidas, e seguramente muito mais 'burláveis'. Isto não apenas pela falta de fiscalização e pela corrupção, mas também, e principalmente, pela menor participação popular no controle e vigilância permanentes sobre este nosso (...) patrimônio ambiental que vem sendo dilapidado por interesses econômicos de curto prazo, que contam com a cumplicidade governamental" (Minc, 1985: p.65).

Segundo Leis (1996), nesse período formativo, a atuação de nossas entidades ambientalistas estava, principalmente, baseada na denúncia e na conscientização pública sobre a degradação ambiental. A partir do final da década de 70 , tomam corpo várias campanhas regionais e nacionais (contra a construção do aeroporto de Caucaia do Alto (SP); contra a inundação de Sete Quedas (PR); contra o desmatamento da Amazônia; contra a construção das usinas nucleares; por leis que regulamentem o uso de agrotóxicos; por atitudes governamentais frente à degradação ambiental em Cubatão (SP); pelo apoio à candidatos ambientalistas ao Congresso).

Na conferência de Estocolmo (1972), o Brasil oferece resistência ao reconhecimento da importância da problemática ambiental (argumentando que 'a principal poluição era a miséria') e se nega - segundo o autor - a reconhecer o problema da explosão demográfica. A Política interna brasileira tinha como pilares: a atração das indústrias poluentes e 0 incentivo para populações desfavorecidas de alta fecundidade para que migrassem para a Amazônia, evitando a reforma agrária nas suas regiōes de origem. Nesse período no Brasil, a problemática ambiental se resumia ao controle da poluição e preservação de algumas amostras de ecossistemas naturais:

"Considera-se que os recursos naturais do Brasil são quase infinitos e que se deve explorá-los do modo mais rápido e intenso possivel, em vez de serem usados de modo conservacionista, para atingir altas taxas de crescimento econômico" (Leis,1996: p. 99).

Nas agências estatais do Sul e Sudeste, rege o princípio da socialização dos custos, por meio de créditos, subsídios e incentivos 
impositivos outorgados às empresas, orientando o estabelecimento dos sistemas de licenciamento ambiental e controle de poluição.

O quadro conflitivo/cooperativo descrito pelo autor, para esse período, entre as agências ambientais estatais e as entidades ambientalistas, parece-nos muito familiar, ainda hoje, ao contexto regional de Piracicaba:

"O conflito é dado pelo questinamento recíproco que agências e entidades fazem de suas atuações na dinâmica sócio-ambiental. Por um lado, as associações percebem as agências agindo com mão branda em relação às indústrias poluidoras e indo muito devagar na apuração das denúncias de degradação feitas pelas entidades. Por outro lado, as agências percebem as entidades como ingênuas (na avaliação das forças econômicas agindo no conflito socioambiental), incompetentes tecnicamente e desrespeitosas do conhecimento técnico detido por aquelas".(Leis, 1996: p. 99).

Mas, nacionalmente, o autor coloca como forças complementares entre os dois atores o estímulo mútuo (onde as posições ambientalistas de ambos se reforçam, seja na comunidade, seja na estrutura estatal), a construção conjunta de políticas ambientais, e o peso que ambos têm juntos na luta contra os valores antiambientalistas. Além do que, muitos técnicos das agências são ao mesmo tempo ativistas nas entidades.

Caminhando para a compreensão da abordagem atual desenvolvida na conservação dos recursos de nossas bacias e microbacias hidrográficas, destacamos ainda alguns pontos do trabalho de Leis. A mudança do contexto institucional federal e estadual (na segunda metade da década de 80), levando a um controle mais rigoroso da poluição industrial e ao desenvolvimento de planos de manejo integrado de microbacias hidrográficas, tiveram na mudança de padrão de atuação da Secretaria Federal do Meio Ambiente (SEMA) em 1986, e na criação do Instituto Brasileiro de Meio Ambiente e Recursos Naturais Renováveis (IBAMA) em 1989, importantes influências. Em relação à SEMA, Leis (1996) destaca viabilização do 
funcionamento do Conselho Nacional do Meio Ambiente (CONAMA), a promoção da problemática ambiental na estrutura do Estado, o favorecimento à interação de agências ambientais estatais e a comunidade científica, além do apoio à interação entre as próprias agências estatais. Em relação ao IBAMA, sua criação " implica uma reforma conceitual-organizacional na definição da proteção ambiental, já que pela primeira vez se associa com 0 uso conservacionista de alguns recursos naturais".

Leis considera que o ano de 1990 foi um ponto de inflexão na definição da problemática ambiental no Brasil, mudando os parâmetros do debate ambiental brasileiro: "Já não se falava mais em proteção ambiental de forma isolada, mas de como atingir um novo estilo de desenvolvimento que a atenda de forma apropriada".

O ambientalismo multissetorial depende, assim, de seus núcleos estadista, comunitário e de mercado (que a partir de 90 são cobrados quanto à sua nitidez), para sua consolidação e a efetivação de seu poder para transformar o modelo de desenvolvimento existente no Brasil" (Leis,1996: p.109).

"Da capacidade de convergência e negociação realista entre esses três setores do ambientalismo dependerá, em última instância, a viabilidade dos possiveis projetos de sustentabilidade a serem aplicados no Brasil" (Leis, 1996: p.112).

0 autor ressalta a defasagem no contexto nacional, entre os discursos, os comportamento individuais e institucionais, e as políticas públicas:

"A importância discursiva da questão ambiental traduziu-se numa legislação comparativamente avançada (...)", porém, "(...) o poder público é incapaz de fazer cumprir, tanto aos indivíduos quanto às empresas, uma proporção importante da legislação ambiental" (Leis, 1996: p. 110).

Concluindo a leitura de parte do trabalho de Leis, para as nossas condições regionais, o autor ressalta a necessidade de se reconhecer no 
ambientalismo multissetorial e no projeto de desenvolvimento sustentável, um eixo de convergência das relações entre sociedade e Estado, frente às características da conjuntura internacional:

"Considerando a importância mundial das forças que se orientam por meio do mercado e, do mesmo modo, o peso significativo no país das forças com um enfoque comunitário, pode-se esperar que no ambientalismo multissetorial brasileiro aumente a responsabilidade do setor empresarial, em conjunto com a dos setores das associações ambientalistas e do socioambientalismo, sendo previsivel que o setor estatal perca, progressivamente, importância" (Leis, 1996: p. 111).

Embora o contexto da presente pesquisa, me leve a entender o Consórcio das prefeituras, como um grupo de pressão ou interesse, que se encontraria no ambientalismo (de acordo com as categorias descritas por Leis) como "grupo interno ao sistema político, que se constitui a partir de uma demanda de proteção ambiental para problemas bem definidos, sem contestar ou desafiar aspectos mais normativos e gerais do funcionamento da sociedade", e de vertente claramente antropocêntrica e individualista (chamada de "alfa" pelo autor), sou provocado a superar a leitura dirigida a encontrar as diferenças, e reconhecer que a solução está nas interações e na integração das diferentes vertentes da ética ecológica. A evolução do conjunto (que não significa a homogeneização das tendências e vertentes) é o que importa.

Nesse sentido, há que se fomentar e aperfeiçoar a participação das entidades civis e representações populares na estrutura que vem se consagrando na gestão dos recursos hídricos na bacia dos rios Piracicaba e Capivari. Desde sua fundação, o Consórcio estabeleceu em estatuto uma Plenária de Entidades como componente de sua estrutura básica. Este, porém, constitui-se como um espaço restrito à participação de "representantes credenciados de entidades civis, legalmente constituídas e sediadas nos municípios consorciados" e desempenha função apenas consultiva (Consórcio, 1996). 


\title{
1.1.2 Participação, comunicação e cidadania
}

\begin{abstract}
"Quando o govemo controla a participação do povo, mas năo é controlado pelo povo, é sinal de que ainda falta muito para se chegar à sociedade participativa. (...) De fato, as condiçరees da participaçåo no mundo atual são essencialmente conflituosas e a participaçăo nåo pode ser estudada sem referéncia ao conflito social. Se desejamos considerar a participação como algo diferente de uma simples relação humana, ou de um conjunto de "truques" para integrar os indivíduos e as coletividades locais nos programas de tipo assistencial ou educativo, năo podemos fugir à análise da estrutura de poder e da sua frequente oposição a toda tentativa de participaçåo que coloque em julgamento as classes dirigentes e seus privilégios" (Bordenave, 1985: p.36 e 41)
\end{abstract}

Diferentemente da percepção dos povos indígenas que habitavam o Brasil antes da invasão portuguesa, o colonizador sempre teve necessidade de substituição da cobertura florestal por atividades agropecuárias no desenvolvimento de sua economia. Segundo Tabanez (1995), no Brasil "o desmatamento foi feito de forma intensiva em toda a região oriental, restando poucas áreas de vegetação natural". Dean, citado por Viana (1990), considera que "no início do século passado, a expansão da cultura do café pelo Vale do Paraíba, sul de Minas Gerais e posteriormente Espírito Santo e Paraná, resultou na derrubada das florestas de encosta para plantio e na extração seletiva para serraria e lenha em outras áreas". Segundo Viana (1990):

"Depois vieram a expansão da pecuária, que foi menos seletiva em termos de topografia e solos, e uma série de outras culturas de subsistência e exportação. Associada a todo o processo de expansão da fronteira agrícola na Mata Atlântica estava a extração madeireira seletiva para construções e exportação, a caça para subsistência e exportação e o uso do fogo."

A série apresentada a seguir mostra a evolução da retirada da cobertura florestal no Estado de São Paulo (fig. 1). 


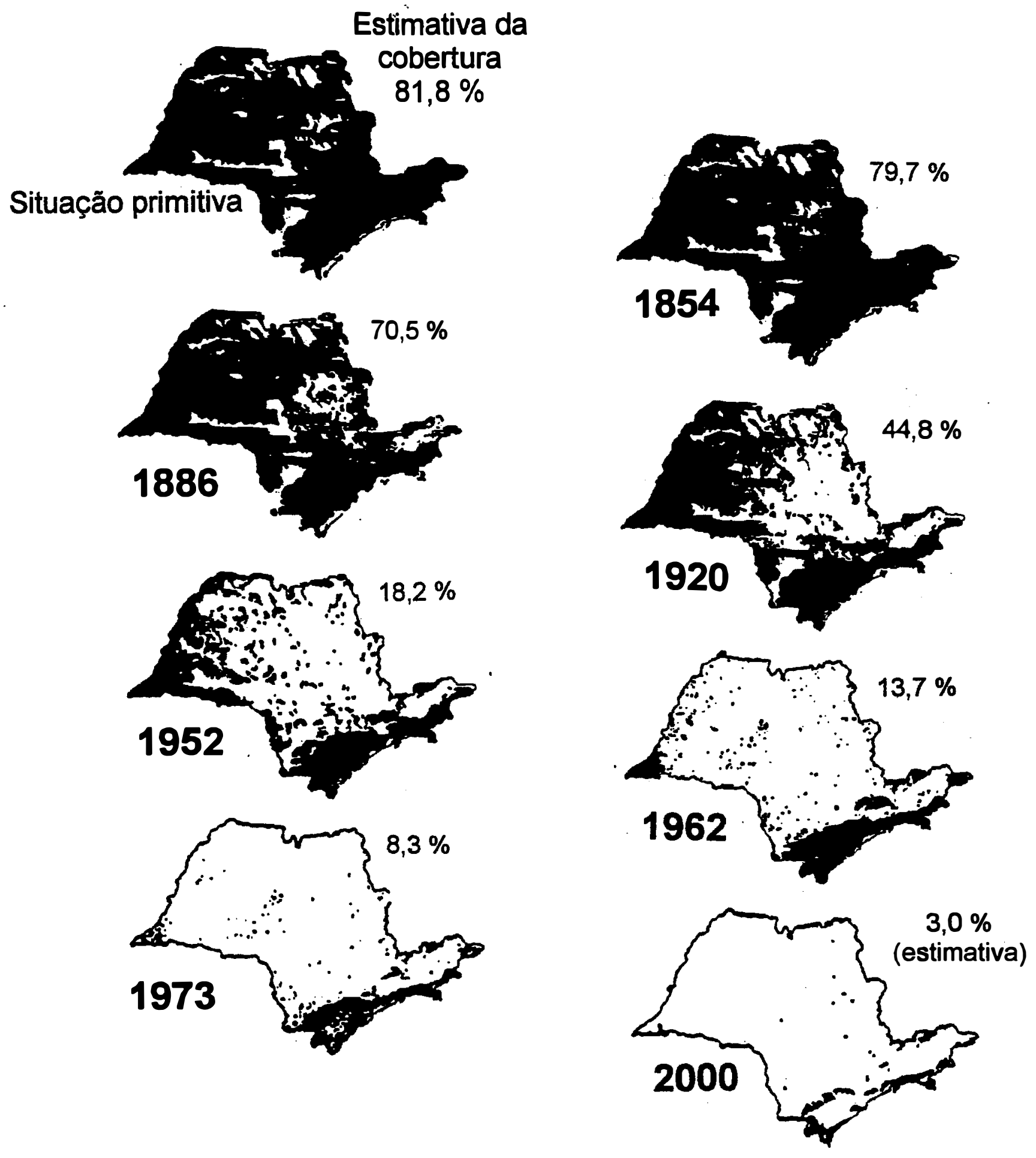

Figura 1. Evolução do desmatamento no Estado de São Paulo, adaptado de Vitor et al. (1975). 
Graziano da Silva analisa esse período (de 1850 a 1950) sobre um outro aspecto, fortemente relacionado à força motriz do desmatamento: a crise do complexo rural e o surgimento do novo complexo cafeeiro paulista. "Foi um longo processo que ganhou impulso a partir de 1850, acelerou-se após a grande crise de 1929 com a orientação clara da economia no sentido da industrialização e se consolidou nos anos 50 com a internalização do setor industrial produtor de bens de capital e insumos básicos (...)" (Graziano da Silva, 1996: p. 5)

Segundo Graziano da Silva, no modo capitalista de produção, o princípio geral que rege as transformações que ocorrem na agricultura é o aprofundamento da divisão social do trabalho, e "o fundamental de toda divisão do trabalho desenvolvida e processada através da troca de mercadorias é a separação entre a cidade e o campo" (Marx, citado por Graziano da Silva, 1996: p. 2).

Tal separação se completa com a mudança da indústria para a cidade, mas ocorre uma reunificação quando "o próprio campo se converte numa fábrica" (Graziano da Silva, 1996). O processo de transformação da base técnica - chamado de modernização - conduz à industrialização da agricultura:

"Esse processo representa na verdade a subordinação da Natureza ao capital que, gradativamente, liberta o processo de produção agropecuária das condições naturais dadas, passando a fabricá-las sempre que se fizerem necessárias" (Graziano da Silva, 1996: p. 3).

Buscando melhor compreender o modo como se desenvolvem ou deveriam se desenvolver as ações que se preocupam com a qualidade ambiental, junto às comunidades rurais, nos aproximamos do contexto da Extensão Rural. No Brasil, nas décadas de 70 e 80, embora argumentasse com mais força sobre a necessidade urgente de aumento da produção e da produtividade, esta já trazia em sua configuração - ao menos no discurso (enquanto serviço oficial público) - elementos que se referiam à qualidade de 
vida e à conservação ambiental. Seria o objetivo do, então, serviço de extensão brasileiro:

"Contribuir para o aumento da produção, produtividade, renda líquida e bem-estar das famílias rurais, sem agressão ao meio ambiente, através de métodos educativos" (MAVMBRATER, citado por Queda, 1987)

O cenário era, então, o da modernização brasileira no campo que, segundo Amstalden (1991), exigiu a necessidade de reformulação no modo de produção agropecuário, para poder enfrentar o desafio que se colocava à nação: produzir alimentos para alimentar à crescente população brasileira mas também (e principalmente) para substituir as importações e aumentar as exportações no setor, fortalecendo o caixa do governo, que bancava assim grande parte dos custos da modernização.

Graziano da Silva analisa mais profundamente a emergência desse novo padrão agrícola que se configura a partir do início da década de 60 , em seu trabalho "A Nova Dinâmica da Agricultura Brasileira". O autor refere-se à análise que Bernardo Sorj faz sobre esse período:

"(...) a partir dessa década há uma quebra nos mecanismos de integração da agricultura no padrão de acumulação industrial, que irá exigir uma reorganização da agricultura a partir da intervenção do Estado e dos novos grupos chamados a orientar a produção agrícola e a renovação das estruturas de dominação. Agora a dinâmica da agricultura estará determinada pelo padrão de acumulação industrial, centrado no desenvolvimento dos complexos agroindustriais e a ação do Estado nesse contexto orienta-se para a modernização da agricultura, visando a integrála ao novo circuito produtivo liderado pela indústria de insumos e processamento de matéria-prima e gerando as condições infra-estruturais necessárias à expansão do conjunto do setor" (Graziano da Silva, 1996: p. 23). 
Cita também Guilherme Delgado que, periodizando o desenvolvimento agrícola recente identifica na institucionalzação do Sistema Nacional de Crédito Rural - SNCR - (em 1965), um período de transição. Segundo Graziano da Silva:

"Aquele momento pode ser considerado como a ruptura do antigo estilo de desenvolvimento e a implantação de um novo padrão agrícola, resultado da conjugação de alguns fatores fundamentais: a consolidação integrada com complexo agroindustrial e as mudanças na base técnica de produção agrícola comandadas pelo complexo; a intensa urbanização e rápido crescimento do emprego não-agrícola, com pressões sobre a demanda de produtos agrícolas; o crescimento e diversificação das exportações; e, finalmente, a organização do SNCR e a política de crédito rural como principal veículo do projeto modernizador para a agricultura" (Graziano da Silva, 1996: p. 26).

Analisando a constituição dos complexos agroindustriais, Graziano da Silva ressalta a qualidade dos novos vínculos intersetoriais como sendo "relações de dominação (técnica, econômica e financeira) do segmento industrial sobre a parte agrícola do complexo".

A correlação que desejamos estabelecer entre a modernização da agricultura brasileira, as diretrizes do serviços de extensão brasileiro, o método de trabalho do técnico extensionista, e os impactos sócio-ambientais resultantes, está esboçada na análise de Graziano da Silva:

"A integração entre a agricultura e a indústria processadora bem como as imposições técnicas que esta estabeleceu sobre a produção agrícola (...) só foram possiveis na medida que se pôde assegurar uma oferta de equipamentos, insumos e variedades agronômicas compatível com as necessidades técnicas impostas à agricultura (...). A industrialização do campo (...) é o momento da modernização a partir do qual a indústria 
passa a comandar a direção, as formas e o ritmo da mudança na base técnica agrícola (...)" (Graziano da Silva, 1996: p. 32).

Resumidamente, os três resultados gerais mais visíveis, segundo o autor, seriam:

- Subordinação da agricultura à dinâmica industrial;

- Mudança no processo de trabalho agrícola ("em que o trabalhador deixa de ser o agente ativo, o controlador do processo de trabalho, para se tornar um apêndice das máquinas");

- A concentração e centralização de capitais e da terra.

A responsabilidade do Estado, que também nos interessa analisar nessa pesquisa, é clara. Ainda segundo Graziano da Silva, a respeito daqueles resultados:

"(...) os três processos descritos foram estritamente dependentes de uma ação estatal específica, ou seja, de um "projeto modernizante" comandado pelo Estado, que ao mesmo tempo que os viabilizava não proveu mecanismos compensatórios sobre seus efeitos sociais na estrutura agrária, nos recursos naturais, nos desequilibrios do abastecimento alimentar, na concentração da renda, nas disparidades regionais, no êxodo rural. Assim, os resultados contraditórios da inserção da agricultura no novo padrão de acumulação manifestaram-se com rapidez e intensidade alarmantes, agravando a crise agrária e rebatendo-a perversamente na crise urbana" (Graziano da Silva, 1996: p. 35).

No campo, junto aos agricultores, estava lançado o desafio aos técnicos, conhecidos como extensionistas. Era tarefa deles desenvolver o encontro com os agricultores, a comunicação, com o objetivo de substituir o modo como produziam por outro. Este último caracterizava-se pelo alto uso de insumos externos à propriedade (adubos minerais, mecanização movida à derivados do petróleo, sementes geneticamente 'melhoradas'), e pelos monocultivos (de maior desequilíbrio ecológico) que consequentemente exigiam 
os biocidas (herbicidas, inseticidas, fungicidas, etc). Por trás destes insumos estavam as indústrias das máquinas, de adubos minerais, de biocidas, associadas aos institutos de pesquisa que desenvolviam espécies ditas melhoradas geneticamente, ou seja, melhor adaptadas ao uso destes novos insumos. Para poder adquirir esses insumos, fator fundamental para o sucesso da adoção desse novo modo de produção era o crédito rural. Esse novo paradigma no modo de produzir, importado dos países chamados desenvolvidos ficou conhecido como o "pacote tecnológico" da revolução verde, e não estava restrito ao Brasil ou à América Latina, mas difundiu-se por quase todo o globo. As avaliações do impacto que esse período histórico trouxe são negativas do ponto de vista social e ambiental, e podem ser encontradas em Bull \& Hathaway (1986), Amstalden (1991), Reijntjes et al. (1994) e Graziano da Silva (1996). Não são, contudo, facilmente aceitas, pois trazem questionamentos de fundo ideológico. Um exemplo disso poderia ser o depoimento do Sr. Polan Lacki (FAO) - durante encontro realizado em Piracicaba em 1997, quando justamente buscava contribuições do meio acadêmico para uma reformulação da formação acadêmica em ciências agrárias - que diz não ter havido impactos negativos, nem ambientais nem sociais, nesse período'.

O fato é que tal pacote foi muito eficiente em selecionar e eliminar aqueles agricultores (a grande maioria pequenos) que não sendo "eficientes" nesse novo modo de produção, também não foram "eficazes" na produção e comercialização, e os altos níveis de endividamento se encarregaram de aumentar a massa de ex-agricultores que se dirigem às cidades para viver em condições precárias de moradia, saúde, trabalho e educação, ocupando favelas e ruas dos grandes centros urbanos.

\footnotetext{
${ }^{1}$ Lacki, P. (consultor da FAO para a América Latina em Desenvolvimento Rural). Comunicação pessoal, em 1997.)
} 
Atualmente, vivemos a preocupação crescente com as questões ambientais, tanto no meio urbano como rural. $\mathrm{O}$ quadro de degradação, não se restringe às regiões povoadas, mas atinge oceanos e as camadas polares, e provoca alterações atmosféricas que são sentidas em todo o globo. Como que num movimento por ondas, a humanidade vem tomando conhecimento da gravidade do quadro e da necessidade de ações concretas, em várias instâncias decisórias (desde municipais até os grandes blocos continentais). Nessa busca, desenvolveu-se a percepção de que o campo educacional é estratégico ao desenvolvimento e efetivação das estratégias conservacionistas. Assim, a educação ambiental foi ganhando destaque no contexto de muitos outros conceitos, como 'desenvolvimento sustentável', conseguindo nesta década, quase que um consenso sobre sua grande importância em projetos que visam o resgate da qualidade ambiental. Devido a essa mesma importância e quase obrigatoriedade da perspectiva educacional nesses projetos, essa tal dimensão educativa começou finalmente a ganhar destaque. Devido às diferentes opções políticas dos mais variados grupos (e por que não dizer também devido à desinformação e pouca experiência de alguns planejadores), como no passado, o que seria essa tal dimensão educativa continua caracterizando-se por ser um espaço de múltiplas facetas (temáticas, políticas, ideológicas, metodológicas), não raro, antagônicas entre si. O mesmo vem ocorrendo com o termo 'desenvolvimento sustentável', a exemplo do que já ocorria com os termos 'bem-estar', 'participação', 'justiça social', etc. Vários grupos - de interesses diversos - se apropriam do termo, e freqüentemente percebem-se em discordância em diferentes graus. Quando suspeita-se que tal abordagem é fruto de uma opção consciente (político-ideológica) a divergência é assumida e trava-se o combate (desde o conflito armado até o científico). Porém o quadro mais comum (e que tem se mostrado muito conveniente aos responsáveis por trabalhos neste contexto) é a ação desenvolvida em nome de um único conceito universal ('educação', 'educação ambiental', 'participação', 'desenvolvimento sustentável'), que acaba por esconder assim os fundamentos, 
os princípios, as crenças daqueles que o pronunciam ao seu público-alvo e à sociedade. Mas, se é possivel o mistério sobre nossas verdadeiras intenções em um projeto escrito, na apresentação de um plano, o mesmo não ocorre com os resultados e impactos causados nas pessoas (embora muitos tentem distorcê-los também, para que a sociedade - e às vezes o próprio autor acredite que o sucesso da ação foi completo).

Para poder entender melhor os fatores que levam as pessoas ou instituições, a adotarem essa ou aquela forma de trabalho (assumindo ou não uma dimensão educativa neste, e de qual qualidade), frente às questões ambientais e na abordagem junto às comunidades, partimos do conceito educacional desenvolvido pelo autor:

"Estamos convencidos de que, qualquer esforço de educação popular, esteja ou não associado a uma capacitação profissional, seja no campo agrícola ou no industrial urbano, deve ter, pelas razões até agora analisadas, um objetivo fundamental: através da problematização do homem-mundo ou do homem em suas relações com o mundo e com os homens, possibilitar que estes aprofundem sua tomada de consciência da realidade na qual e com a qual estão" (Freire, 1983: p.33).

Em sua obra "Comunicação ou Extensão?" (Freire, 1983), o autor levanta o equívoco de se denominar o trabalho do técnico, que se encontra e se comunica com os agricultores, de extensão. Principalmente porque, tem sido o nome mais coerente e apropriado ao modo como se desenvolveu e de desenvolve esse serviço: o técnico estende seus conhecimentos aos agricultores, na esperança que estes substituam seus conhecimentos e modo de agir, por aqueles os quais tais técnicos são mensageiros. Embora Freire tenha levantado tal discussão no contexto da produção agrícola (onde as agências de extensão argumentavam pela urgência da substituição das formas "atrasadas" de produção dos agricultores, em nome da grande necessidade que o país apresentava de aumento da produção e da produtividade), entendemos 
que o tratamento que se dá à chamada crise ambiental vivida atualmente, concretizado no grande número de projetos e programas voltados ao resgate da qualidade ambiental, traz de volta, com muita força, a necessidade de uma maior reflexão crítica sobre o que queremos e para onde vamos com nossas preocupações sobre o ambiente (infelizmente, ainda entendido em muitos círculos no contexto apenas bio-físico, em uma conceituação que exclui o indivíduo e sua ação transformadora na natureza, que é sua cultura).

Comecemos entendendo o que é educação, na leitura de Freire. É antes de tudo "prática da liberdade" para que seja autêntica; ou seja, apenas mulheres e homens livres podem educar e educar-se. Trata-se de uma "situação verdadeiramente gnosiológica", ou seja, um processo cujo sentido não pode ser separado do próprio processo do conhecer, da gênese do conhecimento.

O aprofundamento no estudo de como se dá esse conhecer (os princípios e funcionamento deste processo) nos seres humanos, segundo o autor, nos leva a concluir que a base da educação (daqui em diante entendida dentro dos princípios defendidos por Freire) necessariamente é o diálogo, a comunicação. Precisamos compreender as diferentes formas como o homem conhece, nas suas relações com o mundo. Isso é indispensável para a superação da compreensão ingênua do conhecimento humano, na qual muitas vezes nos conservamos. Isso se reflete nas situações educativas que criamos: o conhecimento do mundo tomado como algo que deve ser transferido e depositado nos educandos.

"O conhecimento (...) exige presença curiosa do sujeito em face do mundo. Requer sua ação transformadora sobre a realidade. Demanda uma busca constante. Implica em invenção e reinvenção. Reclama a reflexão crítica de cada um sobre o ato mesmo de conhecer, pelo qual se reconhece conhecendo e, ao reconhecer-se assim, percebe o 'como' de seu conhecer e os condicionamentos a que está submetido seu ato. (...) 
Conhecer é tarefa de sujeitos, não de objetos. E é como sujeito e somente como sujeito que o homem pode realmente conhecer." (Freire, 1983: p.27)

Entre seus objetivos estaria o de humanizar o homem na ação consciente que este deve fazer para transformar 0 mundo. $O$ humanismo é traço marcante desta concepção de educação; um humanismo com rigor científico (que - segundo o autor - nem por isso deixa de ser amoroso"), que para ser verdadeiro tem que estar alicerçado na prática da liberdade.

O grande contraste que surge na análise que Freire desenvolve, está na qualidade do processo que se desenvolve entre as pessoas (no contexto de sua obra, entre técnicos extensionistas e camponeses, através do serviço de extensão rural, termo combatido pelo autor frente às suas conseqüências práticas na ação daqueles, que ultrapassa uma simples discordância semântica), independentemente de se assumirem como educadores ou de assumirem uma pretensão educativa em suas relações. $O$ contraste entre um processo dialógico e outro, antidialógico.

Pela imprescindibilidade do diálogo no processo educativo, a postura antidialógica acarreta a obstrução de uma série de etapas, associadas a outra série de equívocos quanto ao modo como os homens aprendem (à forma como se dá o aprendizado), conduzindo, como que obrigatoriamente, aqueles que desenvolvem uma ação que aborda conhecimentos e deseja a transmissão destes (como a extensão rural, a educação ambiental, ou nossas aulas, palestras) seguindo esse caminho, à crença de que é possível transferir conhecimentos de um pólo que o tem, a outro que não o tem ainda. Mas:

"(...) a 'educação como prática da liberdade' não é transferência ou a transmissão do saber nem da cultura; não é a extensão de conhecimentos técnicos; não é o ato de depositar informes ou fatos nos educandos; não é a 'perpetuação dos valores de uma cultura dada'; não é o 'esforço de adaptação do educando a seu meio. (...) a educação como prática da liberdade' é, sobretudo e antes de tudo, uma situação verdadeiramente 
gnosiológica ${ }^{1}$. Aquela em que 0 ato cognoscente ${ }^{2}$ não termina no objeto cognoscível, visto que se comunica a outros sujeitos, igualmente cognoscentes." (Freire, 1983: p.78)

"Na educação que seja verdadeiramente uma situação gnosiológica, não há, para o educador, um momento em que, sozinho, em sua biblioteca ou em seu laboratório, conheceu, e outro em que, afastado deste, simplesmente narra, disserta ou expõe o que conheceu" (Freire, 1983:p.79).

A concepção da educação que se reconhece (e vive este reconhecimento) como uma situação gnosiológica, desafia os alunos a pensar corretamente (de modo crítico) e não a memorizar. "Enquanto que a primeira (concepção assistencialista) é rígida, dogmática e autoritária, a segunda é móvel e crítica; daí que não confunda autoridade com autoritarismo, nem liberdade com libertinagem." (Freire, 1983: p.81) '

Deve, portanto, ser problematizadora:

"(...) a concepção educativa que defendemos e que estamos sumariamente colocando como um conteúdo problemático aos possiveis leitores deste estudo, gira em torno da problematização do homemmundo, ou seja, do homem em suas relações com o mundo em que vive. Nesta concepção, os homens devem ser sujeitos do conhecimento, e não objetos a serem preenchidos com conhecimento (concepção 'bancária' da educação, onde os conteúdos são 'depositados' nos educandos), a serem persuadidos, manipulados por propaganda ou adestrados em técnicas." (Freire, 1983: p.83)

E o que seria 'problematizar'? Diz Freire:

"O que importa fundamentalmente à educação, contudo, como uma autêntica situação gnosiológica, é a problematização do mundo do

\footnotetext{
${ }^{1}$ Referente ao processo de conhecer (Michaelis, 1998).
} 
trabalho, das obras, dos produtos, das idéias, das conviç̧ões, das aspirações, dos mitos, da arte, da ciência, enfim, o mundo da cultura e da história, que, resultando das relações homem-mundo, condiciona os próprios homens, seus criadores. Colocar este mundo humano como problema para os homens significa propor-lhes que "ad-mirem", criticamente, numa operação totalizada, sua ação e a de outros sobre o mundo. Significa "re-ad-mirá-lo", através da "ad-miração" da "admiração" anterior, que pode ter sido feita ou realizada de forma ingênua, não totalizada." $E$ dai os homens reconhecem a necessidade de conhecer melhor. "Aí reside toda a força da educação que se constitui em situação gnosiológica." (Freire, 1983: p. 83-84).

Nessa direção caminham também as orientações da Conferência de Tbilisi sobre educação ambiental (IBAMA, 1997), enfatizando cinco categorias de objetivos: consciência, conhecimentos, comportamento, aptidões e participação. Gostaríamos de destacar sua recomendação $n^{\circ} 1$, item 3:

"Um dos objetivos fundamentais da educação ambiental é conseguir que os indivíduos e as coletividades compreendam a natureza complexa do meio ambiente natural e do meio criado pelo homem, resultante da interação de seus aspectos biológicos, físicos, sociais, econômicos e culturais, e que adquiram conhecimentos, valores, comportamentos e habilidades práticas para participarem, com responsabilidade e eficácia, da preservação e solução dos problemas ambientais e da gestão do problema da qualidade do meio ambiente" (IBAMA, 1997: p. 106).

Resumidamente ilustro, a seguir, parte de um processo dialógico no encontro entre educador e educando ${ }^{3}$.

\footnotetext{
${ }^{2}$ Cognição refere-se ao ato de adquirir um conhecimento (Michaelis, 1998)

${ }^{3}$ Paulo Freire prefere o uso dos termos educador-educando e educando-educador, que melhor expressariam a realidade do processo dialógico (Freire, 1983).
} 


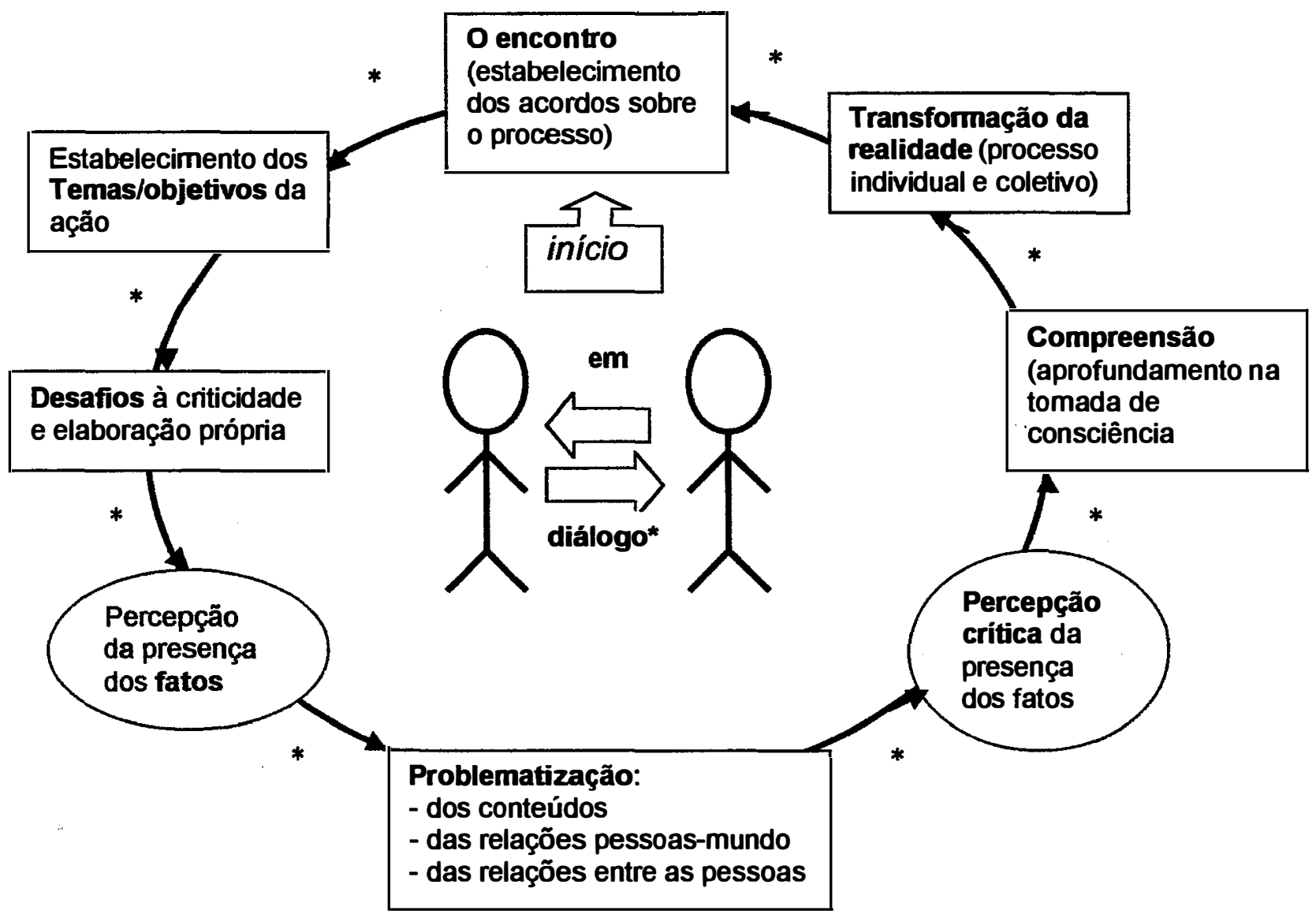

Figura 2. Simplificação de parte de um processo dialógico (baseado em Freire, 1983).

A força da educação. Força transformadora. Transformadora de mulheres e homens que se descobrem cada vez mais como tais, e assim podem ir assumindo seu papel histórico de transformadores de uma realidade que não é imutável, visto que é fruto da própria ação deles. É por isso que negar a presença do indivíduo como um ser da transformação do mundo, subordinando-o à transformação da realidade, que se daria sem sua decisão, é um grande equívoco, fruto das maneiras errôneas de considerá-lo e de explicar 
sua presença no mundo e seu papel na história. Fruto de concepções falsas de educação que aí se originam.

Assim, a ação do agrônomo (nesse contexto da chamada extensão rural, de uma possivel dimensão educativa de programas voltados ao resgate da qualidade ambiental) deve ser a de comunicação, se quiser chegar ao homem - ser concreto inserido em uma realidade histórica. Caso contrário, o camponês estaria sendo transformado em "coisa", objeto de planos de desenvolvimento que o negam como ser da transformação do mundo. Faz-se necessária a presença decisiva do homem nas transformações históricas. E é , segundo o autor, "exatamente em suas relações dialéticas com a realidade que iremos discutir a educação como um processo de constante libertação do homem" (Freire, 1983).

Aproveitamos aqui a reflexão que Freire faz da reforma agrária, para compará-la, nessa análise, à questão da conservação e resgate da qualidade do ambiente, entendendo que são processos muito próximos no tocante ao modo como se estabelecem suas estratégias de ação, como se estruturam os interesses de grupos com poder e produzem discursos à sociedade, escondendo e desperdiçando elementos que poderiam efetivamente contribuir para uma solução:

"A reforma agrária não é uma questão simplesmente técnica. Envolve, sobretudo, uma decisão política, que é a que efetua e impulsiona as proposições técnicas que, não sendo neutras, implicitam a opção ideológica dos técnicos. Daí que tais proposições, para falar só neste aspecto, tanto possam defender ou negar a presença participante dos camponeses como reais co-responsáveis pelo processo de mudança" (Freire, 1983).

- Queremos aqui realçar a força transformadora que os cidadãos comuns possuem, e que, quando adequadamente acolhida, política e amorosamente compreendida, Ética e humanisticamente considerada, 
participativamente desenvolvida, coletivamente trabalhada, revela-se não apenas como solução aos problemas criados por uma sociedade injusta como a nossa, mas como realização de um povo, em seu mais profundo sentido.

Mas de que modo o processo da origem e construção do saber se relaciona com a necessária transformação competente da realidade? Ou em outras palavras, qual a relação entre os conteúdos temáticos, métodos dos programas de conservação ambiental que incidem sobre uma comunidade, e a idéia de que essa comunidade tem a capacidade, legitimidade e o direito de gerir os recursos naturais do ambiente onde vive?

Ocorre que a transformação da uma realidade exige que os sujeitos dessa ação primeiro se aprofundem na tomada de consciência dessa realidade. Para melhor entendê-la, melhor explicá-la e melhor transformá-la. $\mathrm{Na}$ verdade, Freire explica que a conscientização (no processo dialógico, comunicativo) precisa desdobrar-se em ação transformadora da realidade. Nós apenas estamos lendo 'de trás para frente' tal raciocínio: querendo transformar um cenário de degradação ambiental, buscamos 0 processo de conscientização. E a tomada de consciência se dá através da problematização dessas relações do homem com seu mundo (que é cultura), para que evolua da mera captação da presença das coisas, para a percepção crítica dos objetos, desvelando-os nas suas autênticas inter-relações.

Nas palavras de Freire, "o conhecimento se constitui nas relações homem-mundo, relações de transformação, e se aperfeiçoa na problematização crítica destas relações."

Ele cita, ainda, Otávio Paz: "Não são as técnicas, mas sim a conjugação de homens e instrumentos o que transforma uma sociedade" (Freire, 1983: p.56).

Segundo Freire, tal esforço de conscientização, quando bem realizado, permite aos indivíduos se apropriarem criticamente da posição que ocupam com os demais no mundo. Esta apropriação crítica os impulsiona a 
assumir o verdadeiro papel que lhes cabe como homens. $O$ de serem sujeitos da transformação do mundo, com o qual se humanizem.

O que nos traz à reflexão outra área do conhecimento, que é a participação. Muito interessou o estudo que Bordenave (1985) desenvolve em sua obra "O Que É Participação", possibilitando a reflexão integrada de vários aspectos levantados nesta pesquisa, e esclarecendo que a busca por abordagens dialógicas e participativas nas relações entre técnicos e proprietários rurais não se respalda fora de uma estrutura de ação também dialógica e participativa. Ou seja, a análise do comportamento dos proprietários e da forma de atuação dos técnicos é insuficiente para a compreensão da dinâmica dos processos estudados.

No nosso contexto de crise ambiental, as reflexões sobre participação se direcionam à questões como desenvolvimento, democracia e autogestão:

"A participação popular e a descentralização das decisões mostram-se como caminhos mais adequados para enfrentar os problemas graves e complexos dos países em desenvolvimento. (...) o mais importante recurso no processo de desenvolvimento são as próprias pessoas (...)" (Bordenave, 1985: p.13 e 14).

"(...) democracia não é apenas um método de governo onde existem eleições. Para elas democracia é um estado de espírito e um modo de relacionamento entre as pessoas. Democracia é um estado de participação. (...) A democracia participativa seria então aquela em que os cidadãos sentem que, por fazerem parte da nação, têm parte real na sua condução e por isso tomam parte - cada qual em seu ambiente - na construção de uma nova sociedade da qual se sentem parte" (Bordenave, 1985: ps.8 e 23).

O autor alerta para os riscos de vê-la apenas de forma instrumental, "com o perigo que se veja nela algo para ser dirigido, manipulado ou explorado quanto a seus resultados utilitários" (p.14). Ressalta seu caráter 
transformador, considerando-a como processo coletivo que caminha para a construção da autogestão. Esta última implica, segundo ele, "o aumento do grau de consciência política dos cidadãos, o reforço do controle popular sobre a autoridade e o fortalecimento do grau de legitimidade do poder público quando este responde às necessidades reais da população" (Bordenave, 1985: p.20).

"A participação está na ordem do dia devido ao descontentamento geral com a marginalização do povo dos assuntos que interessam a todos e que são decididos por poucos" (Bordenave, 1985: p.12), como é o caso da questão ambiental em nossa sociedade, mais especificamente o enfrentamento da degradação dos recursos hídricos nas bacias dos rios Piracicaba e Capivari. Mais que um instrumento para a solução de problemas, o autor ressalta a participação como "sobretudo, uma necessidade fundamental do ser humano, como são a comida, o sono e a saúde.(...) Sua prática envolve a satisfação de outras necessidades não menos básicas, tais como a interação com os demais homens, a auto-expressão, o desenvolvimento do pensamento reflexivo, o prazer de criar e recriar coisas, e, ainda, a valorização de si mesmo pelo outros" (Bordenave, 1985: p.16). Tal citação nos aproxima do processo de comunicação presente em projetos de intervenção, cuja qualidade pode ajudar a explicar sua aceitação - maior ou menor - junto ao seu público-alvo: "Sabe-se que os membros de grupo participam mais intensamente quando percebem que o objetivo da ação é relevante para seus próprios objetivos. (...) Os líderes comunitários e agentes educativos sabem que o povo participa mais e melhor quando o problema responde a seus interesses e não apenas aos da liderança ou das instituições externas. Sabem ainda que o objetivo deve ficar bem claro para todos os membros. (...) Ela (participação) pode se implantar tanto com objetivos de liberação e igualdade como para a manutenção de uma situação de controle de muitos por alguns" (Bordenave, 1985: ps. 49 e 12). •

O autor propõe uma enumeração decrescente de niveis de importância de decisões, em que podem ser interessante a participação (Bordenave, 1985: p.33): 
1) Formulação da doutrina e da política da instituição;

2) Determinação de objetivos e estabelecimento de estratégias;

3) Elaboração de planos, programas e projetos;

4) Alocação de recursos e administração de operações;

5) Execução das ações e

6) Avaliação dos resultados

Fundamental também é o reconhecimento das forças atuantes na dinâmica participativa, que aqui vem sendo sugerida não como panacéia, mas pela crença em sua adequação à natureza do caso que estamos analisando (um programa de reflorestamento ciliar). $\mathrm{O}$ autor cita algumas delas (Bordenave, 1985: p. 48 a 50):

1) instituições sociais;

2) organização social informal (comportamentos padronizados, códigos de comunicação, normas grupais);

3) diferenças individuais (a serem aproveitadas de forma construtiva);

4) atmosfera geral (muito influenciado pelo tipo de liderança existente);

5) informação sobre si e seu ambiente (contínuo processo de criação de conhecimento pelo grupo - requer abertura de canais informativos confiáveis e desobstruídos);

6) mecanismo de realimentação (feed-backs que ajudam a reconhecer no processo as consequências de seus atos);

7) diálogo. "(...) a maior força para a participação é o diálogo. Diálogo, aliás, não significa somente conversa". Tem como requisito melhorar nossa capacidade de falar e escutar, mas também o domínio de técnicas de dinâmica de grupos e uso efetivo dos meios de comunicação;

8) a desigualdade de poder, que segundo o autor "conspira contra a participação". Segundo ele, a franqueza é afetada pelo grau da diferença hierárquica de poder presente, talvez o maior ponto fraco do Programa aqui estudado; 
9) comunicação tem melhor fluência entre semelhantes e os de maior aceitação e status puxam novos rumos para a comunicação;

10) o nível de participação das pessoas é inversamente proporcional ao tamanho do grupo. Este aspecto pode ajudar a entender melhor a estratégia do Programa (veja em Resultados e Discussão, no capítulo 3).

É nesse contexto que entendemos a cidadania:

"(...) a participação social e política é a luta das classes populares para que as classes dirigentes cumpram seu dever. (...) A participação não tem, pois, somente uma função instrumental na co-direção do desenvolvimento pelo povo e o governo, mas também exerce uma função educativa da maior importância, que consiste em preparar o povo para assumir o governo como algo próprio de sua soberania, tal como está escrito na Constituição. (...) Através da participação, a população aprende a transformar o Estado, de órgão superposto à sociedade e distante dela, em órgão absolutamente dependente dela e próximo dela" (Bordenave, 1985: p.56).

Assim se dá o efeito multiplicador de processos educativos: "(...) a participação das pessoas em nível de sua comunidade é a melhor preparação para a sua participação como cidadãos em nível da sociedade global." (Bordenave, 1985: p.58).

Entre as ferramentas operativas necessárias para tail processo, o autor cita o conhecimento da realidade, a organização, a comunicação e a educação para a participação (Bordenave, 1985).

A idéia que permeia todo esse dissertação está centrada na conviç̧ão de que a conservação ambiental (nas suas mais variadas formas de manifestação e ação) não prescinde do desenvolvimento da cidadania, da qual a educação (enquanto verdadeiro processo do 'conhecer' humano, em suas relações com o mundo e em suas relações com outros homens e mulheres) é 
ferramenta e fundamento, também imprescindível. Como diz Bordenave (1985), "A participação é uma habilidade que se aprende e se aperfeiçoa".

Assim, enquanto a abordagem dessas ações ambientais junto à comunidade (rural ou urbana) não tiver esse sentido maior de estímulo à participação e a processos dialógicos na construção do saber, de contribuir para a organização de mulheres e homens para que junto com os técnicos possam 'melhor entender, explicar e transformar' suas realidades, continuará sendo - na melhor das hipóteses - uma "atitude ingênua frente à existência humana" (Freire, 1983). Na pior das hipóteses, será uma articulação ideológica de manipulação das massas para que estas mais uma vez sejam (como foram, a grande maioria de pequenos proprietários rurais na revolução verde) 'objeto de planos de desenvolvimento que os negam como seres da transformação do mundo'.

\subsubsection{Construção do conhecimento}

"Duas ordens de conseqüências advêm do reconhecimento da ciência como queståo de meio e de método:

a) como meio, a ciência pode ser usada e abusada, dependendo dos fins implicados, o que explica a predominância de conhecimentos dirigidos para objetivos destrutivos; sabemos mais destruir do que construir, mais agredir do que promover, mais guerrear do que fazer a paz, mais produzir do que ser feliz;

b) como método, a ciência tende a reduzir-se a seu aspecto formal, cáustico, detergente, encobrindo (...) as ideologias mais escusas ou discursos mais complexos que úteis" (Demo, 1994: p. 20). 
Pensando no papel do conhecimento nos processos de transformação, de desenvolvimento, já indicado por Freire (1983), buscou-se um aprofundamento teórico que possibilitasse entender as limitações, oportunidades e perspectivas que se visualizam em ações que de algum modo esbarram na questão do conhecimento, como são as ações de conservação e/ou resgate da qualidade do ambiente, como é uma ação de proteção aos mananciais que se estrutura através de um programa de reflorestamento ciliar.

Em Demo (1994) encontramos a valorização da construção do conhecimento, como instrumentalização para a ação, para a transformação, dentro do contexto de resgate da importância da pesquisa como atitude cotidiana do cidadão comum, favorecendo um processo transformatório:

"Se buscamos uma cidadania emancipada, capaz de projeto próprio de desenvolvimento, ou se buscamos garantir aos marginalizados condições equânimes de luta, o instrumento mais decisivo, hoje, é a habilidade de manejar e produzir conhecimento" (Demo, 1994: p. 33).

Embora o autor desenvolva sua argumentação de modo a chamar a atenção para a crise de nosso sistema formal de ensino, que tradicionalmente impede o desenvolvimento crítico e criativo dos alunos (refletindo em uma falsa cidadania, onde o desenvolvimento da nação não vem de projetos sonhados, escritos e conduzidos pela população, mas de pequenos grupos que os tornam objetos de outros planos de desenvolvimentos), julgamos adequada sua interpretação para as condições dessa pesquisa, que vem chamar a atenção para as estratégias e métodos utilizados no referido programa. Principalmente por trabalhar tão próximo ao conhecimento (dos proprietários, dos técnicos, do promotor de justiça, da Ciência), e de fazer dele, conforme as conjunções de poder atuantes, base ideológica que justifica e fortalece um modo de ação.

Preocupa-nos a boa intenção dos idealizadores e coordenadores de programas que se voltam para o desafio de minimizar, brecar ou reverter a atual crise ambiental e buscam (através da educação ambiental) a substituição de uma forma de conhecimento considerada inadequada ambientalmente, por 
outra que julgam ser a correta. Seja pela sedução (como o trabalho dos extensionistas agropecuários a serviço da revolução verde) seja pela coerção (frente à dispositivos legais). Não conseguem compreender, entretanto, que a natureza do processo de conhecer das pessoas não se resume à transmissão de informações, de comunicados, mas se dá num contexto de comunicação, de dialogicidade com a realidade e com os outros; de liberdade. Como geralmente o processo comunicativo não se dá fora de uma estratégia e de uma estrutura institucional de ação (pois é nesse âmbito que ele é forjado), a implantação dessa prática exige que ultrapassemos a análise da relação técnico-proprietário rural. Caminhando na mesma direção de Freire, afirma Demo:

"(...) 'repetir para decorar'. Se isto cabe nos animais, que funcionam pelo reflexo condicionado, os seres humanos são capazes de questionar de modo crítico e criativo, cabendo-lhes formação, e não adestramento. A maneira humana de internalizar conhecimento não é repetir para decorar, mas aprender a aprender, saber pensar. Ou seja, a maneira humana de internalizar é construir." (Demo, 1994: p. 69)

Daí o nosso interesse no aprofundamento desse tema que parece tão distante da realidade estudada: é realmente necessária e urgente a mudança de modo de pensar e agir dos proprietários rurais frente às questões que os cercam. Ocorre que a questão ambiental (da conservação dos recursos hídricos, das matas ciliares, entre outras) é apenas uma delas, e eles, no seu modo de vida (memórias, ações, planejamentos) sabem muito bem disso. Assim, ações pontuais que partem do ponto de vista de agentes externos às peculiaridades locais, são tentadas a enxergar na força da lei o caminho mais "viável", ao menos nas condições precárias (de recursos humanos e financeiros) como estão estruturadas tais ações e instituições, ainda hoje. Uma preocupação ética com o desenvolvimento humano poderia começar a transformar tais posturas nos técnicos, mas não viria de forma mágica, de um momento para o outro. Viria pela percepção (que pede algum esforço) de que, 
em termos objetivos, de resultados (entendidos não de forma reducionista, mas sistêmica, como exige também a própria abordagem moderna da questão ambiental), cada vez mais nos defrontamos com o sucesso de ações que buscaram na valorização e fortalecimento de mulheres e homens, uma das principais fontes de soluções aos problemas em que eles estão relacionados (inclusive os ambientais).

Estariamos falando, então (para o nosso caso específico do programa de reflorestamento desenvolvido), de pelo menos quatro contextos de produção e manejo de conhecimento, a serem mais aprofundados:

1.1.3.1. O conhecimento de como reflorestar estas faixas de preservação permanente - antigamente matas ciliares - e a aplicação desse conhecimento;

1.1.3.2. O conhecimento do lugar e importância da presença das matas ciliares como florestas de proteção às áreas adjuntas às diferentes expressões dos recursos hídricos (nascentes, córregos, rios, lagos, represas) e sua aplicação, embasando e justificando a legislação referente, principalmente o Código Florestal, de 1965;

1.1.3.3. O conhecimento resultante da pesquisas que foram desenvolvidas para a elaboração de diagnósticos da situação atual dos recursos hídricos na bacia dos Rios Piracicaba e Capivari, e sua aplicação enquanto embasamento (ou ideologia) justificador das estratégias adotadas;

1.1.3.4. O conhecimento de um método de trabalho que mais se adequou às características (competências e limitações) da parceria de instituições promovida pelo Consórcio, e sua aplicação na microbacia do Ribeirão Forquilha, a partir de 91.

A idéia dos próximos itens é evidenciar a forte presença e influência, para a estruturação das ações aqui estudadas, dos conhecimentos que as embasam, e o grau com que eles são (ou deveriam ser) reconstruídos nas próprias ações e discursos (na prática dos agentes). A eficiência e dificuldades desse processo de aquisição de conhecimento, entre os técnicos, 
podem nos ajudar a compreender sua natureza (ou lembrar dela, refletindo sobre nosso próprio processo de aprendizado), também para o contexto dos proprietários rurais. Mais que isso, nos possibilita visualizar e compreender a questão do poder, cada vez mais atrelado à informação (produção e manejo do conhecimento).

\subsubsection{Revegetação}

Para este primeiro nível, destacaríamos as contribuições de Paulo Kageyama ${ }^{1}$ ao desenvolvimento e aperfeiçoamento dos modelos de revegetação que vem sendo usados nos reflorestamentos ciliares (Kageyama, 1987; Macedo, 1993). De forma muito resumida e simplificada, nos arriscamos a trazer alguns dos princípios básicos.

A base do conhecimento sobre revegetação vem da dinâmica da floresta tropical; o modo como as espécies se regeneram e se desenvolvem naturalmente.

"Isso se dá através da queda de árvores, provocando a formação e clareiras de diferentes tamanhos, que são ocupadas por novos individuos de diferentes espécies. A variação das clareiras no espaço e no tempo dá origem a um mosaico de diferentes estágios sucessionais" (Macedo, 1993: p. 4).

A luz seria o principal fator de influência à colonização das clareiras: dependendo da maior ou menor tolerância das espécies à sombra (resposta das clareiras à luz ou ao sombreamento do dossel), separam-se as espécies arbóreas em grupos ecológicos (embora este seja apenas um dos critérios utilizados). Didaticamente e operacionalmente, usam-se os termos pioneiras, secundárias e climácicas:

\footnotetext{
${ }^{1}$ Professor doutor, titular do Departamento de Ciências Florestais da ESALQ/USP.
} 
"Deve-se observar que esta classificação tem sentido puramente de orientação para os plantios mistos e não deve ser entendida de forma rígida e definitiva. Isto porque ainda é restrita a compreensão sobre o processo de dinâmica da floresta tropical, assim com também são escassas as informações silviculturais das espécies em plantios mistos" (Macedo, 1993: p. 6)

Segundo a autor, o objetivo da revegetação seria o de "criar condições para que uma área degradada recupere algumas características da floresta original, criando uma nova floresta com características estruturais e funcionais próximas às das florestas naturais" (Macedo, 1993: p. 7)

No trabalho de revegetação, são sugeridos alguns procedimentos gerais (Macedo, 1993: p. 8):

1) uso exclusivo de espécies nativas de ocorrência regional;

2) existência de informações silviculturais sobre as espécies;

3) utilização do maior número de espécies, para promover a diversidade e a conservação dos recursos genéticos;

4) preferencialmente, usar sementes de no mínimo 10 árvores para cada espécie, colhidas se possível de florestas naturais, para minimizar os efeitos de consangüinidade (que podem levar à perda de vigor e extinção da população no médio prazo, considerando-se gerações).

As formas de distribuição dos diferentes grupos ecológicos no local onde se pretende a revegetação, dá origem a diferentes modelos de revegetação. Mas:

"... somente a aplicação dos modelos não garante o sucesso da revegetação. A escolha do melhor modelo deve ser feita cuidadosamente, levando-se em conta vários fatores. As exigências das espécies e a sua adaptação às condições locais de solo, clima e umidade, por exemplo, são elementos importantes para a escolha do modelo. Outro fator relevante seria o conhecimento prévio da área a ser revegetada, o que pode ser obtido mediante o levantamento de informações tais como: 
1) levantamento histórico da área quanto à sua utilização, preparo do solo, cultivo, etc.;

2) caracterização do local a ser revegetado, quanto a condições de clima, fertilidade, textura, permeabilidade e profundidade do solo, topografia e presença de água (altura de lençol freático, umidade, encharcamento, inundações periódicas etc.);

3) caracterização do tipo de formação vegetal existente originariamente e aferição das espécies e ocorrência regional;

4) seleção das espécies nativas regionais adaptáveis ao local a ser revegetado; $\mathrm{e}$

determinação do percentual de participação em função da cobertura vegetal existente originalmente no local a ser revegetado, do grupo ecológico ao qual pertence e levantamento da freqüência ou raridade com que cada espécie ocorre naturalmente" (Macedo, 1993: ps. 8 e 9)

Em áreas com grau menor de degradação (capoeiras ou áreas de mata recentemente abertas, com banco de sementes viável e proximidade à fragmentos), pode se ainda pensar em outras estratégias, como o enriquecimento de capoeiras ou o simples abandono e proteção da área.

A estratégia de revegetação varia, de acordo com as condições locais, de modo que cada característica local (histórico de uso, condições edafo-climáticas, gramíneas invasoras, grau de degradação) deve ser associada à elementos de otimização do desenvolvimento da revegetação, tais como o espaçamento, agressividade das pioneiras (crescimento e sombreamento mais rápidos, tolerância à herbivoria), exigências quanto à fertilidade do solo, desenho do modelo, espécies utilizadas (inclusive não arbóreas, como leguminosas, em consórcios), forma de plantio (sementes, estacas, mudas).

Ainda para o sucesso da revegetação, ressalta-se a importância da manutenção e proteção (pós-implantação), do cuidado especial que se deve 
ter com a formação das mudas nos viveiros, a proteção da área contra a entrada de animais (pisoteio e herbivoria), eliminar periodicamente espécies invasoras agressivas, e manutenção de aceiros contra o fogo. $O$ autor enfatiza, ainda, que a estratégia de revegetação das matas ciliares deve estar associada à ligação destas com as reservas (fragmentos) existentes na bacia hidrográfica.

Assim sendo, parece evidente a importância da participação e do conhecimento (ainda que senso comum) do proprietário, ou moradores mais antigos, para o sucesso de um programa de reflorestamento ciliar, assim como a imprescindibilidade dos técnicos de campo compreenderem os princípios que regem a revegetação, mais que decorarem os modelos até hoje desenvolvidos.

\subsubsection{Ação da mata ciliar na proteção aos recursos hídricos}

Apresentamos a seguir, pequena revisão sobre o assunto, buscando problematizar a questão da largura das faixas de preservação permanente preconizadas no código florestal, e também relativizar os discursos dos técnicos do programa aqui estudado, no que se referem ao aumento da quantidade de água e função protetora dos recursos hídricos, quando atribuem apenas à recomposição dessas matas, tal responsabilidade.

\section{Mata ciliar}

O que é

Vegetação característica das margens de rios, córregos e lagos, e de ampla distribuição (Nogueira, 1989; Kageyama et al., 1989; Barbosa, 1989), a mata ciliar "apresenta espécies adaptadas, tolerantes ou indiferentes a solos encharcados e/ou sujeitos a inundações temporárias", com algumas espécies exclusivas, sendo importante habitat para animais e fonte de alimento para peixes (Kageyama et al., 1989). 
Determinantes

Suas características variam de acordo com o local de ocorrência, em função da flutuação do lençol freático, microclima, regime de chuvas, mecanismos adaptativos das espécies de solos temporariamente alagados, tipo e fertilidade de solo, topografia, entre outros (Barbosa citado por Barbosa, 1989; Nogueira, 1989).

Está sob influências dinâmicas dos cursos d'água, em freqüência e intensidade no tempo, dependentes de características geológicas, geomorfológicas, climáticas, edáficas, hidrológicas, locais e regionais (Christofoletti; Leinz \& Amaral; citados por Mantovani, 1989). Troppmair \& Machado, citados por Mantovani (1989) e Reichardt (1989), entendem ser a umidade do solo o maior condicionante da vegetação, relacionado, por sua vez, com o regime pluviométrico, a topografia local, os traçados dos rios e os tipos de solo, sendo que "sua influência é alterada pelas freqüências, intensidade e duração de inundações" (Camargo et al.; Hoehne; Hueck; citados por Mantovani, 1989). Enfim, Mantovani (1989) considera que os vários fatores "atuando de forma conjunta, de maneira e com importância distintas no tempo, criam condições ambientais muito diversas para a ocorrência de matas na beira de cursos de água, o que acarreta em variações estruturais e florísticas, independentes de ações antrópicas".

\section{Nomenclatura}

Embora o termo mais empregado na literatura existente seja "mata ciliar" - por formar verdadeiras pestanas nos diques marginais formados por sedimentos, nos grandes rios - podemos encontrar outros também referentes à ocorrência ao longo de cursos fluviais, como 'floresta beira-rio', 'de borda', 'justafluvial', 'marginal', 'ribeirinha', 'ripária', 'ripícola', entre outros. Outros termos como 'floresta de galeria', 'mata de fecho', 'mata de anteparo', 'floresta de 
condensação', 'mata aluvial', 'floresta paludosa', 'floresta de várzea'... já representariam algumas peculiaridades para diferentes manifestações da diversidade de condicionantes e de ocorrências anteriormente mencionados (Mantovani, 1989). Sem contar os termos referentes às formações mais típicas de alguns ecossistemas como as 'veredas', no nordeste, ou quando há o predomínio de determinada espécie: 'carandaval', 'paratudal', acurizal', 'carnaubal', 'babaçual', 'buritizal' (Bezerra dos Santos; Campos; Veloso; Hueck; Sampaio; Warming; Joly; Romariz; citados por Mantovani, 1989).

Frente ao uso das expressões 'área ripária' ou 'área ciliar', usadas para a representação do terreno (barranco e área de inundação) com condições edafo-climáticas e vegetação próprias, Lima (1989) sugere o termo 'ecossistema ripário' para designar o conjunto formado pela área ripária, mata ripária e interações com o meio. Também para Catharino (1989), "ecossistemas ribeirinhos" seria o termo mais adequado para abordar a diversidade de associações vegetais existentes, e os diversos estágios secundários de regeneração de cada uma delas, pois "não encontramos apenas florestas nas beiras de cursos d'água". Sugere o autor, que nos restrinjamos ao uso dos termos "mata ou floresta, ciliar ou ripária" para formações vegetais florestais que acompanham os cursos d'água, e mesmo dentro desse grupo, que analisemos separadamente as matas que se localizem em regiões onde a formação circundante for campestre, daquelas onde existe uma cobertura florestal contígua.

Características edafo-climáticas

Os tipos de terreno percorrido pelos rios, em geral - para o Estado de São Paulo - apresentam-se como vales (seção em "V"), ou com diques/tabuleiros em ambas as margens (seção em "U"), ou muito alterados pela erosão, com a calha expandida devido à assoreamentos, com lagoas e brejos distantes do leito original (Nogueira, 1989). 
Estão bem caracterizadas nos estados do sul e Brasil central, principalmente nas regiões de domínio campestre e savânico, onde são distintas fisionomicamente (Barbosa, 1989; Mantovani, 1989). Nessas regiōes, "raramente atingem grandes extensões", podendo chegar a 150 metros a partir das margens dos rios, enquanto que as grandes planícies fluviais amazônicas, inundáveis, chegam a 100 quilômetros (Barbosa, 1989).

Estão, portanto, filiadas às grandes províncias florestais contíguas - como a mata atlântica, amazônica e do rio Paraná (Ab'Saber, citado por Mantovani, 1989). Ou associadas à condições excepcionais nas regiões dos campos sulinos, gerais e do cerrado, principalmente devido à maior umidade do solo (Bezerra dos Santos; Luetzelburg; Troppmair et al.; Warming; citados por Mantovani, 1989).

"Os solos que normalmente são encontrados sob essas formações vegetais são formados, preponderantemente, por um processo denominado de adição, e apresentam uma variabilidade muito grande quanto às características químicas e mineralógicas" (Demattê, citado por Mantovani, 1989).

São solos que geralmente se apresentam com maior umidade e fertilidade. "Nos terrenos aluviais mais estreitos, com rios menores, o material é muito semelhante ao dos solos adjacentes" (Bunting, citado por Mantovani, 1989).

"A natureza dos aluviões, a composição e a textura dos solos, além da profundidade do lençol freático, são responsáveis por variações e, mẹsmo, determinantes da presença de florestas à beira dos cursos fluviais" (Bertoni \& Martins; Camargo et al.; Gouvea; Hueck; Lindman; citados por Mantovani, 1989).

Segundo Mantovani (1989), a dinâmica dos cursos fluviais também controla a existência e o desenvolvimento de matas na beira d'água. 


\section{Florística}

A mata ciliar, vem ganhando a atenção nos trabalhos referente às principais formações florestais brasileiras. Embora pouco conhecidas, sabe-se fruto de processo de seleção ambiental principalmente relacionado com a freqüência de alagamentos (Porto et al., citado por Barbosa, 1989).

Consequentemente, as características da composição florística dessas matas são consideradas especiais e também estão profundamente relacionadas às condições edafo-climáticas e às formaçōes vegetais existentes nas regiões onde ocorre (Barbosa et al., 1989). Para Reichardt (1989) a evapotranspiração (que é máxima devido à máxima condutividade hidráulica dos solos saturados) é um dos fatores que diversifica a flora dentro da área ripária, além da própria adaptação das espécies.

Embora um grande número de autores sugiram que a cobertura vegetal paulista dominante - à época do 'descobrimento' - fosse florestal, a situação atual de extensos campos cultivados e pastagens assemelha-se às áreas de formações campestres, como no Brasil central (Catharino, 1989). Porém, segundo o autor, as florestas ciliares do território paulista mantém características fitogeográficas distintas.

Desafios à pesquisa

Ao final do I Simpósio sobre Matas Ciliares realizado pela CARGILL, em 1989 (Campinas, SP), entre outras conclusões estava a identificação de "grandes lacunas no seu entendimento, decorrentes da ausência de pesquisa científica, da quase inexistência de trabalhos interdisciplinares e da complexidade de situações em que se encontram" (Simpósio, 1989: p. 333). Durigan \& Dias (1990) consideram fato recente a pesquisa e experimentação sobre matas ciliares, dentro da ciência florestal. Catharino (1989) ressalta a problemática referente à "precária situação das 
ciências biológicas no Brasil", reflexo da falta de incentivo governamental para as pesquisas básicas em geral, refletindo na má formação do brasileiro e do pesquisador na área. Conclui que pouco conhecemos sobre a estrutura e funcionamento dos ecossistemas vegetais brasileiros - com o qual concorda Delitti (1989), e mais especificamente ainda sobre os ecossistemas ripários -, e que fala-se muito de 'mata ciliar', sem saber a exata representação deste termo.

Segundo Reichardt (1989) a literatura referente à estimativa dos fluxos de água subsuperficiais em áreas ciliares - "fundamental para a análise do comportamento hídrico da bacia" - é escassa, sugerindo mais estudos.

A palavra final sobre o significado do termo "mata ciliar", para Catharino (1989), é um estudo que ainda está para ser feito, que considera escassos os dados florísticos sobre vegetação ripária. Isso dificultaria, segundo o autor, por exemplo, a recomendação de um maior número de espécies e/ou gêneros de ampla distribuição geográfica para programas de reflorestamento ciliar que busquem também a conservação genética.

Os trabalhos que têm enfocado a flora ribeirinha, segundo Catharino (1989), têm mostrado o nosso quase completo desconhecimento à respeito desses ecossistemas, lembrando, por exemplo, da não inclusão de espécies epifitas, herbáceas e arbustivas - em relação aos quais a flora ripária apresenta-se muito rica. $O$ autor recomenda a regionalização dos estudos envolvendo os ecossistemas ribeirinhos.

Delitti (1989) considera que existe "um claro descompasso entre a capacidade de nossa sociedade gerar conhecimento científico e seu poder de interferir e modificar a natureza".

\section{Benefícios e modo de proteção ambiental} Microclima

"No fundo de vales é comum observar-se a ocorrência de neblina e a condensação de vapores de água, nos períodos de secas e de 
abaixamento das temperaturas, ao menos nas primeiras horas do dia. Isto se deve à manutenção, pela água, de temperaturas superiores às do ar, provendo às florestas que as ocorrem com maior umidade" (Campos; Warming; citados por Mantovani, 1989).

Serapilheira de florestas

"A serapilheira acumulada sobre o solo de florestas tem um papel importante na dinâmica destes ecossistemas pois as transformações que ocorrem neste compartimento são responsáveis pela maior parcela do fluxo de energia dentro do sistema ao qual está associada a reciclagem de nutrientes. Além de constituir um elo fundamental no fluxo de energia e nutrientes, a serapilheira acumulada é um importante reservatório de elementos que pode conferir maior estabilidade ao sistema" (Jordan \& Kline, citados por Delitti, 1989). "Além disso, protege o solo atenuando forças erosivas, como as chuvas, por exemplo" (Delitti, 1989).

\section{Ciclagem de nutrientes}

Segundo Delitti (1989), sobre o aspecto da ciclagem de nutrientes entre os diversos compartimentos dos ecossistemas, as formações ripárias têm recebido especial atenção, devido à sua distribuição peculiar, restrita às faixas de contato entre os ambientes terrestres e aquático, conferindo-lhe papel determinante para a estruturação e dinâmica do ambiente.

"A grande proporção entre a sua zona perimetral, em relação à área total do ecossistema, aliada à sua posição fisiográfica, resulta num sistema profundamente envolvido com múltiplas relações de troca com os ambientes aquático e terrestre adjacentes" (Delitti, 1989). 
O autor destaca a participação da mata ciliar no controle da passagem de elementos essenciais do meio terrestre para o aquático.

\section{Função hidrológica da mata ciliar e filtro de sedimentos}

"As áreas ripárias são reguladoras de fluxos de água (superficiais e subsuperficiais) e de sedimentos (que levam consigo nutrientes) entre as áreas mais altas da bacia hidrográfica e o sistema aquático. Atuam como filtros e por isso são também designados como 'sistema tampão' "(Corbett \& Lynch, citados por Reichardt, 1989).

Steinblums et al., e Platts, citados por Lima (1989), consideram como principais formas de desempenho da função hidrológica do ecossistema ripário:

- Estabilização das ribanceiras por emaranhados radiculares;

- Participação no controle do ciclo de nutrientes na bacia hidrográfica, pela absorção de nutrientes dos escoamentos superficial e subsuperficial;

- Diminuição e filtragem do escoamento superficial, impedindo ou dificultando o carreamento de sedimentos para o sistema aquático;

- Proporciona cobertura e alimentação para peixes e outros componentes da fauna aquática;

- Intercepta e absorve radiação solar, contribuindo para a estabilidade térmica dos pequenos cursos d'água.

Meguro e Shimizu, citados por Delitti (1989), confirmam a relação positiva entre a cobertura florestal e a qualidade da água de reservatórios, em Paraibuna, SP. 
Largura da faixa de mata ciliar

Segundo Lima (1989), esta deve variar com as próprias condições da bacia hidrográfica, corforme - pelo menos - quatro características, relacionadas com a topografia e o solo: a condutividade hidráulica do solo, a profundidade do lençol freático, o fluxo subsuperficial de água que chega ao canal e a declividade. Na verdade, tais características referem-se ao conceito mais amplo de 'área variável de contribuição', necessárias ao seu mapeamento (Lima, 1989). Segundo o autor, "as larguras mais comumente consideradas como próprias variam de 12 a $30 \mathrm{~m}$ de cada lado do canal".

\footnotetext{
"Tanto para o planejamento adequado do uso do solo em uma bacia, visando a garantir a permanência de seu funcionamento harmônico, quanto para a execução de programas de recuperação de mata ciliar em bacias já degradadas, um passo importante seria a identificação e o mapeamento destas áreas" (Lima, 1989).
}

Dunne et al., citados por Lima (1989), desenvolveram metodologia expedita, que leva em conta a topografia, o solo, a vegetaçã́o e alguns parâmetros hidrológicos. Lima recomenda que tais informações sejam prontamente utilizadas em programas de recuperação de matas ciliares.

Zakia (1998) aplicou método de identificação da zona ripária em uma microbacia hidrográfica, em Arapoti (PR). Relacionou informações referentes à vazão, precipitação e distribuição horizontal de quatro espécies arbóreas gerando, através de modelagem, um mapeamento da zona ripária. A comparação entre esse resultado e a faixa de preservação permanente (relativa à mata ciliar) exigida pelo Código Florestal, pode ser vista na figura 3. 


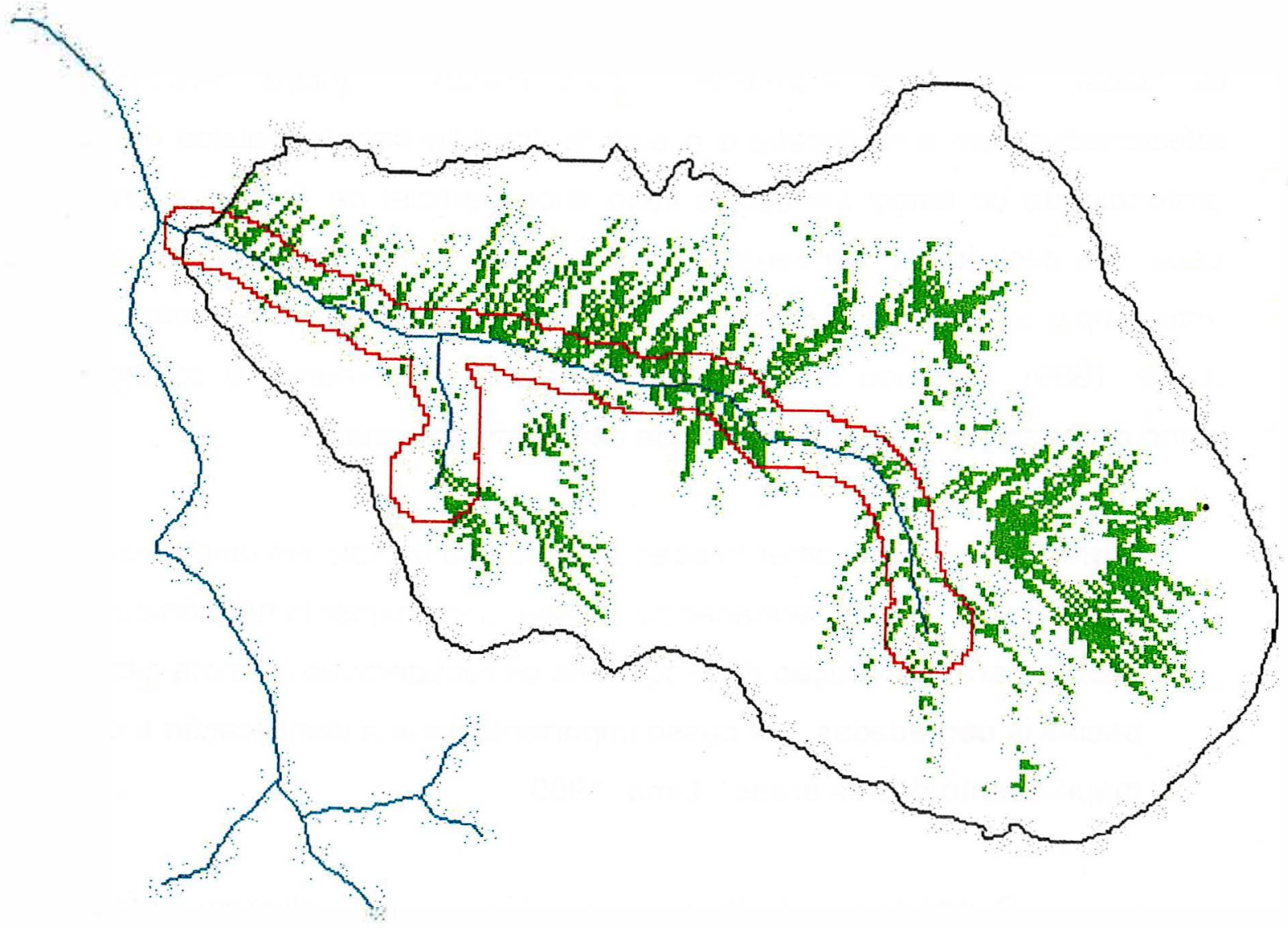

Figura 3. Zona ripária (em verde) e faixa de mata ciliar exigida pelo Código Florestal (em vermelho), extraído de Zakia (1998).

Consumo de água

Reichardt (1989) considera que muito pouco foi estudado sobre o assunto, em nosso meio. Em geral, afirma o autor, o porte da vegetação não afeta muito as perdas por evapotranspiração, sendo que, não havendo restrições de água no solo, "a evapotranspiração de um gramado não difere mais que $20 \%$ da de uma mata ou floresta". Sobre o manejo de ecossistemas ripários, alguns autores analisam o corte dessa vegetação visando a economia de água (Richardt, 1989). 
Dinâmica da água no solo de ecossistemas ripários

Os caminhos percorridos pela água da chuva que chega à superfície de uma bacia hidrográfica poderiam ser assim apresentados: uma pequena fração incide sobre a superfície líquida da rede de drenagem, e o restante divide-se em infiltração (escoamento subsuperficial - devido ao declive e camadas de impedimento no subsolo - e percolação em direção ao aquifero) e escorrimento superficial, descontadas as perdas por evaporação e transpiração (Lima, 1989; Reichardt, 1989). O chamado escoamento direto, é formado pela precipitação sobre os canais, pelo escoamento superficial e pelo escoamento subsuperficial, e sua representação no hidrograma (representação temporal do deflúvio produzido por uma chuva qualquer), chamada de hidrograma direto. Wipkey citado por Lima (1989), confirmou ser o escoamento subsuperficial, e não o escoamento superficial - como se pensava -, o principal componente no processo de geração desse escoamento direto, em microbacias florestadas, contribuindo significativamente para a alimentação dos cursos d'água (Reichardt, 1989). E Betson, citado por Lima (1989), verificou que geralmente apenas uma área pequena da bacia hidrográfica originava 0 hidrograma direto. Para definir essas pequenas porções de terrreno da bacia hidrográfica que participam da geração do hidrograma direto de uma dada chuva, Hewlett \& Hibbert, citados por Lima (1989) desenvolveram o conceito de "área variável de contribuição". São zonas de saturação ou de encharcamento superficial nos terrenos mais baixos, ao longo das margens da rede de drenagem, que influenciam o escoamento rápido que resulta de uma dada chuva (Lima, 1989). "Quando a chuva é muito prolongada, ocorre expansão das áreas saturadas...", por isso mesmo 'variáveis' (Lima, 1989). "Quando o escoamento subsuperficial a partir das partes mais altas da bacia excede a capacidade do solo de transmitir este fluxo, a água tende a aflorar" (Rawitz et al.; O'Loughlin; citados por Lima, 1989). 
Para Lima (1989), os processos de:

- Precipitação direta na superfície líquida da rede de drenagem;

- Escoamento superficial nas partes da bacia onde as condições de infiltração do solo estejam prejudicadas;

- Escoamento superficial nas áreas saturadas;

- Escoamento subsuperficial;

- Expansão da rede de drenagem,

tornam as áreas referentes a eles, os locais mais críticos, em termos de sua resposta hidrológica à ocorrência de uma chuva. "São, portanto, áreas que devem estar sempre em boas condições de proteção, com cobertura vegetal adequada (...)" (Lima, 1989). É a partir destas considerações que o autor realça a importância hidrológica da mata ciliar, "e de todo o ecossistema ripário".

Contribuições da mata ciliar no controle da qualidade da água

Um aspecto prático de aplicação do conceito de área variável de contribuição, no manejo de bacias hidrográficas, é a diminuição do "escoamento superficial, que pode causar erosão e arraste de nutrientes e de sedimentos para os cursos d'água", e o efeito de filtragem superficial e subsuperficial dos fluxos de água para os cursos d'água, pela presença da mata ciliar, que normalmente ocorre naquelas áreas mais sensiveis (margens, nascentes e áreas saturadas) (Kunkle, citado por Lima, 1989).

Karr \& Schlosser, e Schlosser \& Karr, citados por Lima (1989) demonstraram que "a presença de mata ciliar em microbacias cultivadas intensivamente é responsável pela manutenção de menor concentração de sedimentos no deflúvio".

Pensando no manejo da bacia hidrográfica como um todo, e levando-se em conta a maximização da função de proteção desse 
ecossistema, Lowrance et al. e Lowrance \& Shirmohammadi, citados por Lima (1989), concluíram, com base nos resultados obtidos em ensaio experimental:

- Em microbacias agrícolas, a manutenção da qualidade da água depende da preservação da mata ciliar;

- A remoção da mata ciliar leva ao aumento do transporte de nutrientes ao curso d'água;

- A manutenção desse processo de absorção de nutrientes do escoamento superficial pelo ecossistema ripário, pode ser conseguido pelo corte seletivo periódico de indivíduos da mata ciliar.

Delitti (1989) também the confere destaque na atenuação de forças erosivas.

Efeitos hidrológicos negativos da mata ciliar

- Para Sopper et al., citado por Lima (1989: p.35), a presença da mata ciliar na beira de rios ou reservatórios pode contribuir para a deposição de material vegetal na água, podendo "causar problemas do ponto de vista da sua utilização para abastecimento público.

Existe ainda, em regiões semi-áridas, a possibilidade de competição por consumo de água, pela presença da vegetação ripária (Gay, citado por Lima, 1989). Nesses casos, analisados um a um, Lima (1989) acredita que o manejo da vegetação ripária possa resultar em economia razoável de água, porém, através do corte seletivo, evitando-se o corte raso. Mas, segundo Ritzi, citado por Lima (1989), isso poderia criar outros problemas hidrológicos, já que a mata ciliar situa-se na parte mais sensivel da bacia hidrográfica. Delitti (1989), porém, confere à ela papel de destaque na perenização dos cursos d'água. 


\section{Reflexos para a fauna}

"A destruição, e a fragmentação dos corredores que as matas de galeria representam, certamente trariam grandes prejuízos para a fauna de extensas regiōes". Medidas para a conservação das matas de galeria no Brasil, significaria - entre outros aspectos - a proteção de um grande patrimônio genético que corresponde à sua fauna e flora, ainda pouco conhecidos (Marinho Filho \& Reis, 1989).

\section{Manejo integrado da bacia}

Segundo Omernik et al., citado por Lima (1989):

"(...) não se deve, é claro, concluir que a mera presença da mata ciliar seria suficiente para sanear todos os problemas da poluição agrícola em uma bacia hidrográfica, a menos que outras medidas complementares de manejo adequado de uso do solo sejam tomadas".

Uso local

A vegetação que a compõe é considerada por Nilsson (1989) de importância como pasto apícola.

\section{Recuperação}

Justificativas

É crescente a preocupação para com a "manutenção e recuperação da vegetação ripária, visando a preservação do habitat da fauna, assim como do funcionamento hidrológico da bacia hidrográfica" (Graf, citado por Lima, 1989). 
Floristica e genética

Segundo Catharino (1989), a grande diversidade da configuração geomorfológica dos locais onde se desenvolve qualquer forma de vegetação ripária influencia diretamente a sua fisionomia e composição florística atual.

"A configuração fitogeográfica e geomorfológica atual é decorrente da complexa história paleoclimática do sul e sudeste brasileiros. Ou seja, a flora migrou, estabeleceu-se e, até mesmo, desapareceu de determinados locais, flutuando ao ritmo das mudanças climáticas do passado" (Catharino,1989: p. 64).

Em períodos mais secos (como no glacial), as formações florestais teriam permanecido apenas nos locais mais favorecidos quanto à umidade; mas quando o clima tornava-se mais úmido, esses refúgios de populações da flora e fauna poderiam se expandir.

"Assim, os principais acidentes do relevo paulista e os cursos dos maiores rios, poderiam ter servido como refúgio da flora silvática ou de mata", a exemplo do que atestam os 'brejos' no nordeste brasileiro (Catharino, 1989: p. 64).

Entre o planalto ocidental (domínio dos cerrados à oeste-noroeste dessa província) e o planalto atlântico (domínio das florestas úmidas de encosta), "encontra-se a depressão periférica, coberta em sua maior parte por uma formação florestal mais seca que a atlântica e menos xeromorfa que o cerrado, denominada de 'floresta estacional semidecidual' ou 'floresta mesófila' " (Catharino, 1989: p. 63).

Considerando que estas populações mantiveram-se isoladas por formações vegetais mais xerófilas, Catharino (1989) considera que existiram 
condições para a formação de populações diferenciadas localmente ou ecotipos:

"Se isto realmente ocorreu, as populações de espécies vegetais ribeirinhas devem ser bastante diversificadas e a manutenção desta variabilidade torna-se muito importante. Assim, quando fala-se em preservação e reposição florestal deve-se levar em consideração a manutenção das bases genéticas das populações locais, facilitando a regeneração natural e utilizando matrizes locais nos programas de reflorestamento com nativas, notadamente das espécies de menor área de distribuição geográfica ou raras" (Catharino, 1989: p. 64).

Apesar disso, o autor considera a existência de espécies de ampla distribuição geográfica, que poderiam ser recomendadas de maneira geral para o reflorestamento de áreas ripárias de diferentes regiōes (guanandi, peito-depomba, marinheiro, gêneros Inga e Erythrina). Ele afirma que não existem bases sólidas para a citação de outras espécies, necessitando-se maiores estudos.

Espécies

Catharino (1989) cita Croton urucurana, Cecropia pachystachia, Enterolobium contortisiliquum e Inga uruguensis como típicas da regeneração da floresta ripária. "À medida que a floresta vai ocupando o terreno e amadurecendo, a influência da água vai sendo minimizada, surgindo condições para que outras espécies, que antes não poderiam ocupar os terrenos úmidos, comecem a aparecer. Estas espécies são aquelas que têm sido denominadas de indiferentes, aparecendo nas etapas mais maduras tanto da floresta ripária quanto da floresta mais distante do rio" (Catharino, 1989: p.67).

Adaptações às condições de saturação 
Segundo Mazzoni-Viveiros \& Luchi (1989), "a ocorrência de inundações periódicas nas matas ciliares impõe à flora destas áreas mecanismos de sobrevivência às condições de saturação hídrica e, consequentemente, de anoxia". Estudos de aspectos eco-fisiológicos do lenho de espécies de mata ciliar, tem sido desenvolvidos pela Seção de Anatomia e Morfologia do Instituto de Botânica de São Paulo, frente à escassez de dados relativos à presença de possíveis mecanismos de sobrevivência às condições de anoxia que tais espécies enfrentam nos períodos de inundação, principalmente os de hábito arbóreo, dos trópicos.

\section{O Código Florestal}

A Lei 4.771, de 15/09/1965, "institui o novo código florestal" Artigo $2^{\circ}$ - Foi alterado pela Lei 7.511 de 07/07/86, passando a ter a seguinte redação:

Consideram-se de preservação permanente, pelo só efeito dessa Lei, as florestas e demais formas de vegetação natural situadas:

a) Ao longo dos rios ou de qualquer curso de água, desde o seu nível mais alto em faixa marginal, cuja largura mínima será:

1. de 30 (trinta) metros para os rios com menos de 10 metros de largura.

2. De 50 (cinqüenta) metros para os cursos que tenham de 10 a 50 metros de largura.

3. De 100 (cem) metros para os cursos de água que meçam entre 50 e 100 metros de largura.

4. De 150 (cento e cinqüenta) metros para os cursos de água que possuam entre 100 e 200 metros e largura.

5. Igual à distância entre a margens para cursos de água, que possuam largura superior a 200 metros 
Artigo 18 - Nas terras de propriedade privada, onde seja necessário o florestamento de preservação permanente, o Poder Público Federal poderá fazê-lo sem desapropriá-las, se não o fizer o proprietário.

$\S 1^{\circ}$ - Se tais áreas estiverem sendo utilizadas com cultura, de seu valor deverá ser indenizado o proprietário.

$\S 2^{\circ}$ - As áreas assim utilizadas pelo Poder Público Federal ficam isentas de tributação.

Artigo 26 - Constituem contravenções penais, puníveis com três meses a um ano de prisão simples ou multa de uma a cem vezes o salário-mínimo mensal do lugar e da data da infraçāo, ou ambas as penas cumulativamente:

a) destruir ou danificar a floresta considerada de preservação permanente, mesmo que em formação, ou utilizá-la com infringência das normas estabelecidas ou previstas nesta Lei;

b) cortar árvores em florestas de preservação permanente, sem permissão da autoridade competente;

c) penetrar em floresta de preservação permanente, conduzindo armas, substâncias ou instrumentos próprios para caça proibida ou para exploração de produtos ou subprodutos florestais, sem estar munido de licença da autoricade competente;

(...)

g) impedir ou dificultar a regeneração natural de florestas e demais formas de vegetação;

(...)

m) soltar animais ou não tomar precauções necessárias para que o animal se sua propriedade não penetre em florestas sujeitas a regime especial.

Embora tenha caído o veto da lei 9.989 em maio de 1998 - lei que obriga os proprietários paulistas a recuperar suas matas ciliares e encostas de morros - esta "continua a ser letra morta", como diz a jornalista Regina Scharf. Tal lei fora proposta pelo Deputado Estadual Ivan Valente, sendo que ele mesmo já a havia proposto a dez anos. Segundo Scharf (1998), 5\% do território 
paulista é composto por Áreas de Preservação Permanente (APPs), já incluídas as "margens de rios, encostas muito íngremes e topos de montanha. (...) apenas um sexto dos 24 milhões de hectares de APPs paulistas conservam sua cobertura vegetal. São aproximadamente 37 mil quilômetros de rios com margens degradadas e sujeitas à erosão" (Scharf, 1998). Segundo a jornalista, o diretor geral do DEPRN alerta para a incapacidade de oferta de mudas par tais reflorestamentos: "se todos resolvessem recuperar suas APPs, não haveria mudas de espécies nativas para todos" (Ronaldo Crusco, citado por Scharf, 1998). Frente às propostas do DEPRN (um substitutivo à lei, ampliando prazos e incentivos econômicos para a recuperação das APPs - cita a possibilidade de descontos na futura cobrança pelo uso da água), o Deputado Estadual acredita que os proprietários deveriam ter iniciativa própria, e critica a política do que chama de "presentinhos" aos proprietários (Scharf, 1998).

Aproveito para destacar alguns artigos do Código das Águas, de 1934, citados por Minc (1985: p. 82):

Art. 109 - A ninguém é lícito conspurcar ou contaminar as águas que consome, com prejuizo de terceiros.

Art. 110 - Os trabalhos para salubridade das águas serão executados à custa dos infratores que, além da responsabilidade criminal, responderão pelas perdas e danos que causarem e pelas multas que lhes forem impostas nos regulamentos administrativos.

O autor cita também um artigo do Código Penal de 1940: "corromper ou poluir água potável de uso comum ou particular, tornando-a imprópria para consumo ou nociva à saúde. Pena: reclusão de dois a cinco anos" (Minc, 1986: p.82). E acrescenta ainda, o artigo $1^{\circ}$ do Decreto 50.877 , de 1961: "os resíduos líquidos, sólidos ou gasosos, domiciliar ou industrial, somente poderão ser lançados às águas, "in natura" ou depois de tratados, quando esta operação não implique na poluição das águas receptoras" (p.82).

Entendo que se justificam, desse modo, as preocupações referentes à aplicação de leis, cujo embasamento científico não está claro, 
obstruindo a possibilidade de contribuições do cidadão comum, tanto ao desejado questionamento do conhecimento científico (condição, aliás, imprescindivel para que ele assim seja considerado), como para a reformulação e aperieiçoamento da legislação (no caso, ambiental), para que esta seja eficaz, porque sua aplicação será mais eficiente.

\subsubsection{Diagnóstico do nível de degradação dos recursos hídricos das bacias dos rios Piracicaba e Capivari}

Em linhas gerais, os coordenadores dos programas do Consórcio expressam uma visão muito grave a respeito do futuro dos recursos hídricos nas bacias':

Sérgio: "Bom. Na minha visão, como é que está a situação atual da bacia. Nós tamo ainda a caminho do caos, né. Mais do que sabido isso daí. 0 Consórcio tinha um estudo feito, que em 2010, ia ter um colapso total por falta d'água. Mas nós estamos achando que isso vai ocorrer bem antes, pelo desenvolvimento que tava, como se diz, mais... mais acelerado que ... no que foi estimado, e os problemas também cresceram, agravaram-se, né. Hoje, noventa e... acho que $98 \%$ do esgoto não é tratado..."

entrevistador: "Isso é bacia do Piracicaba e Capivari?

Sérgio: "É... Bacia do Piracicaba e Capivari. E desses... - acho que é $98 \%$ que o [Edison] me passou esses dados, $98 \%$ - e do que é tratado boa parte é da indústria, mas a indústria, mesmo assim, a parte, ou o resíduo que ela solta ainda é poluente.

Dizia o coordenador do programa "Semana da Água", durante palestra proferida na abertura de uma das etapas do Treinamento Completo

\footnotetext{
${ }^{1}$ Ver entrevista com Sérgio, em Anexo B. Todos os nomes dos entevistados nesta pesquisa foram trocados por nomes fictícios (veja o capítulo 2, Metodologia).
} 
(Teórico, Prático e Aplicativo) para Capacitação de Coordenadores e Professores aplicadores do programa (1997):

"... então o conflito pela água é uma coisa que hoje, nos nossos dias, está sendo comum. Em 94 nós tivémos problema seríssimo também envolvendo Indaiatuba, Salto e outros municípios... e isso vai se repetir. E aí é o que os municípios acabam fazendo, infelizmente: água mole em pedra dura, tanto bate até que... muda de direção! Então os municípios tentam suprir suas águas nos pequenos córregos, nos pequenos ribeirões, e acabam não conseguindo. E muitas vezes acabam não conseguindo porque esses córregos e ribeirões estão com as suas vazões bem diminuídas. Por que? Por uso e ocupação do solo irregular, por ausência de mata ciliar, por falta de programas rurais para recarga do lençol freático... - no nosso treinamento nós falamos isso. Então, o que acaba acontecendo? Todo mundo vai pegar água nos grandes cursos de água, e a resposta que eu dou para vocês é a seguinte: isso vai levar ao caos. $O$ caos, inclusive tem data: é mais ou menos 2010. Agora mesmo Hortolândia tá anunciando que vai procurar água no Jaguarí. E todo mundo fala: 'ou eu vou pegar água no Atibaia, ou no Jaguarí ou no Piracicaba'. Piracicaba foi pro Corumbataí. (...) Mas eu tô colocando para vocês os seguintes pontos: os grandes cursos d'água estão sendo hoje muito disputados. Será que essa água é suficiente para todos? Tá? Então, um trabalho que vocês vão começar aqui - e já começaram nas suas escolas - é o de conscientização, e a proteção do pequeno olho d' água."

Essas avaliações (somadas à algum convívio, fruto do envolvimento do pesquisador), parece-nos refletir, a forte conviç̧ão desses coordenadores de que algo deve ser feito com urgência. A perspectiva do "caos", parece mobilizar as pessoas para a ação, ou pelo menos para a adesão das soluções propostas (como a criação da 'Agência de Bacia', empresa regional que admistrará os recursos a serem arrecadados na futura cobrança pelo uso da água), com o risco de estabelecer estratégias de ação e métodos 
de trabalho apoiados pela opinião pública, mas que contradizem o desenvolvimento humano necessário à superação da atual crise, que não é apenas ambiental.

Em entrevistas com os técnicos do Serviço Autônomo de Água e Esgoto (SAAE) de Capivari ${ }^{1}$, constatamos que a água que vem da Represa Milhã (Ribeirão Forquilha) recebe apenas o tratamento convencional (possivel indicativo de sua boa qualidade), e que entre $24 \mathrm{~h}$ e $5 \mathrm{~h}$ toda a água captada da represa é jogada diretamente no rio Capivari por incapacidade de armazenamento; ainda segundo os técnicos esgoto simplesmente não é tratado na cidade ( $0 \%$ ), embora já esteja $97 \%$ 'afastado' (captado).

No trabalho da Coordenadoria de Planejamento Ambiental (CPLA), entitulado 'BACIA DO RIO PIRACICABA: Estabelecimento de Metas Ambientais e Reequadramento dos Corpos D'Água' (São Paulo, 1994) encontramos um estudo aprofundado sobre vários aspectos, da bacia do rio Piracicaba. Embora não tenhamos acesso a informações referentes a bacia do rio Capivari, entendemos poder ilustrar bem a questão levantada da produção e manejo do conhecimento, neste contexto.

Sobre as cargas poluidoras, o estudo divide-as entre pontual e difusa, para os setores urbano, industrial e agrícola. Revela que apenas $4 \%$ (3,5 ton DBO/dia) da carga total urbana (de aproximadamente 88 ton DBO/dia, estando contempladas apenas as produzidas por populações atendidas pelas redes de esgoto) é tratada. Para o setor industrial, "os ramos industriais de alimentos, têxtil, químico, de papel e tinturaria são os que mais poluem os corpos d' água da bacia, representando $79,8 \%$ da carga total (...)", estimada em 1.547 ton DBO/dia (apenas de origem orgânica, 1.280 ton DBO/dia das usinas e indústrias de aguardente, e 267 ton DBO/dia para outras indústrias,

${ }^{1}$ Douglas Carravero (auditor), Orlando Rodrigo (topógrafo, assessor), Femando Angelim (Eng. Civil), Ronaldo de Cillo (diretor), João F. Martins de Godoy (técnico químico da ETA I, de Capivani). Comunicação pessoal, 1998. 
aproximadamente). Desses, o que mais diretamente se relaciona com a carga poluidora é a carga residual, que respectivamente seria 75 ton DBO/dia (total), sendo 3 ton DBO/dia de usinas/ aguardente e 72 ton DBO/dia das outras.

"Os índices de redução dos ramos industriais de alimentos (40\%), têxtil $(67 \%)$, bebidas $(68 \%)$, aguardente $(46,4 \%)$ e tinturaria $(15,4 \%)$ estão bem abaixo dos $80 \%$ previstos na legislação". Por 'redução', podemos entender o tratamento dos efluentes.

Assim, "a carga poluidora industrial de origem orgânica lançada nos corpos d'água, representa $47,2 \%$ do total, enquanto que a carga residual urbana representa $52,8 \%$. No entanto, a carga potencial industrial representa $94,6 \%$, contra $5,4 \%$ da carga urbana, revelando os riscos iminentes dessa atividade à biota e à saúde pública. Alguns estudos preliminares da CETESB já demonstram a necessidade de um controle da toxicidade dos efluentes gerados" (São Paulo, 1994).

Quanto às cargas difusas (não-pontuais), estas representariam $13 \%$ da carga poluidora urbano-industrial (calculada em 159,4 ton DBO/dia), assim distribuídas:

Área Rural

a) culturas temporárias - 5,4 ton DBO/dia;

b) culturas permanentes - 1,5 ton $\mathrm{DBO} / \mathrm{dia}$;

c) atividade agro-silvo-pastoril - 1,2 ton DBO/dia;

d) pastos $-11,4$ ton $\mathrm{DBO} / \mathrm{dia}$

Sub-total - 19,6 ton DBO/dia

Área Urbana (população não esgotada) - 1 ton DBO/dia TOTAL: 20,6 ton DBO/dia.

Segundo a pesquisa, o alto índice de crescimento dos setores urbanos, industriais e agrícolas tem levado ao crescimento das demandas pelos recursos hídricos da bacia. "O atendimento dessas demandas vem sendo satisfeito prioritariamente através de obras para reservação de água em 
detrimento de ações de planejamento, racionalização, diminuição de perdas, etc. Uma das conseqüências desse processo foi a construção de um grande número de barragens e lagos artificiais para geração de energia elétrica, abastecimento urbano e irrigação".

A respeito dos 'mananciais para abastecimento público', a pesquisa limitou-se a avaliar o impacto ambiental potencial causado pelas atividades econômicas nos mananciais da bacia. Caracterizou os principais 'problemas ambientais' (considerados impactos parciais) que comprometeriam a quantidade e qualidade da água, nestes mananciais de captação urbana, decorrentes do uso e ocupação do solo. Os principais fatores considerados na pesquisa, para tal avaliação foram:

1) cobertura vegetal (quanto menor a área de mata ciliar, maior o impacto potencial);

2) suscetibilidade à erosão laminar e profunda;

3) uso atual do solo (em função da densidade das atividades antrópicas e do tipo de cobertura vegetal existente);

4) lançamentos urbanos e industriais.

E complementam:

"É importante destacar que o diagnóstico e a avaliação prévia dos impactos ambientais analisados servem apenas como indicadores da ocorrência de possiveis situações críticas nos mananciais de captação urbana da Bacia do Rio Piracicaba. Porém, para o reconhecimento de cada situação especifica, torna-se necessária a avaliação direta de cada manancial."

O diagnóstico aponta para a necessidade de ampliação das captações já existentes ou, para outros municípios, a busca de novos mananciais, de modo a atender às demandas até o ano 2010. Uma das evidências dessas análises seria a de que:

"os mananciais utilizados atualmente deverão ser protegidos, pois todos serão utilizados no mínimo até o ano 2010. (...) Observa-se ainda que a 
avaliação do impacto potencial das atividades antrópicas nas áreas de mananciais possibilitou verificar o nível crítico em que se encontram essas áreas".

Conclui que, 50 dos 61 mananciais analisados podem estar sofrendo alto ou altíssimo grau de impacto ambiental.

Parece que vem de estudos como esse, a motivação daqueles que, tendo escolhido a proteção dos mananciais como principal linha de ação do Consórcio (veja entrevista com o coordenador geral da Secretaria Executiva do Consórcio), buscam com veemência a revegetação das áreas de preservação permanente (nas antigas áreas das matas ciliares), mesmo que no 'porrete'. 2

Mas como chegamos a esse quadro? Ainda nas informações do referido estudo:

"A política de desenvolvimento implantada a partir da década de 70, com o objetivo maior de gerar energia e produtos para exportação, favoreceu a expansão de determinados setores industriais na região, notadamente o agroindustrial. Esse crescimento econômico produziu significativa transformação no parque industrial e nas áreas agrícolas e urbanas, acentuando as alterações ambientais dos municípios da bacia e as diferenças regionais" (São Paulo, 1994: p. 12).

No setor agropecuário:

"A agricultura brasileira tem passado por modificações tecnológicas e de ocupação territorial. $O$ instrumento básico para seu dinamismo foi o crédito rural, cujo grande aumento no período 60/79 influenciou positivamente a performance do setor. Essa modernização beneficiou de forma diferenciada regiões e culturas. Na década de 80 , apesar da crise econômica e da diminuição do crédito rural, o setor primário brasileiro teve uma taxa de crescimento da ordem de $3,6 \%$ ao ano, superando o 
crescimento industrial. O Estado de São Paulo foi um dos favorecidos pela política de crédito rural e mantém relativo dinamismo na década de 80 , amparado também pela industrialização e urbanização ocorridas na década anterior. Nesse período crescem as culturas exportáveis, como laranja e soja, e as energéticas como a cana, que recebe subsídios e incentivos do PROÁLCOOL, não sofrendo os efeitos da crise. Houve também incremento de produtividade em culturas como arroz, cebola, batata e tomate. Outra característica marcante é a expulsão de culturas de menor rentabilidade econômica para outras regiōes do País" (São Paulo, 1994: p.12).

Para a região de Campinas, da qual faz parte a bacia do rio Piracicaba:

"A modemização do setor primário na região pode ser caracterizada por alguns indicadores. A mecanização pode ser avaliada pela relação área/trator. Em 1980 a região apresentava o valor mais alto do Estado: 9,2 tratores por 1.000 hectares. A média do Estado era de 6,2. A região também apresenta a utilização mais intensiva de insumos químicos e sementes selecionadas. Outro ponto a se salientar foi o crescimento da área irrigada. No período de $80 / 85$ a taxa média de crescimento foi de $8 \%$ ao ano. O efeito do quadro apresentado foi o aumento do rendimento físico e a diminuição do contingente de trabalhadores no setor" (São Paulo, 1994: p.13).

E conclui:

"(...) a modernização agrícola ocorrida na região foi intensa, superando as médias do Estado de São Paulo. Esse processo teve efeitos sobre a industrialização e a urbanização, e deve-se ressaltar que produziu impactos na qualidade ambiental da região como decorrência do uso

\footnotetext{
${ }^{2}$ Sobre o contexto do uso desta expressão, veja a entrevista com o coordenador geral do Consórcio, no Anexo B.
} 
intensivo do solo, assim como de insumos mecânicos e químicos" (São Paulo, 1994: p.13).

Ainda sobre o desenvolvimento regional:

"Até a década de 70, a região e Campinas apresentava situação favorável em termos de oferta de serviços e equipamentos sociais, superando a média brasileira e a da capital. Com a intensificação da industrialização e desenvolvimento agropecuário, ocorreu aumento populacional não acompanhado do incremento dos equipamentos e serviços sociais, o que levou à deterioração da qualidade de vida" (São Paulo, 1994: p.16).

"Como ficou demostrado, as atividades produtivas, especialmente dos setores industrial e terciário, ocorrem de forma concentrada em alguns municípios da bacia, notadamente na área conurbada. Como decorrência dessa concentração é nesses trechos da bacia que os recursos naturais encontram-se mais degradados e onde a disponibilidade e a qualidade dos recursos hídricos são motivo de preocupação" (São Paulo, 1994: p.17).

Desse modo, parece claro a relação entre o desenvolvimento da região e a degradação dos recursos naturais.

\subsubsection{Estratégia de ação e métodos de trabalho}

Em 1991, na elaboração do plano de atuação do Consórcio o 'Programa de Proteção aos Mananciais de Abastecimento Público atuais e futuros' foi um dos priorizados, pois "uma das grandes preocupações das administrações municipais é o aumento gradativo dos custos para o tratamento das águas visando torná-las em condições de consumo pela população, como 
também, resguardar a quantidade e qualidade das mesmas" (Ricardo e Romani, 1992: p.135). O sub-programa de reflorestamento ciliar seria apenas mais uma das ações que deveriam ser desenvolvidas.

Buscando um embasamento ao trabalho que seria desenvolvido e também experiências que apresentassem inter-relação entre instituições governamentais e o proprietário rural, foi considerada a metodologia mais adequada aquela desenvolvida pela Associação de Defesa e Educação Ambiental de Maringá (ADEAM), entre outras experiências que se buscou, dentro e fora do Estado (Ricardo e Romani, 1992).

Pelo relato dessa experiência, estavam envolvidos Itaipú Binacional, ADEAM e o Instituto de Terras, Cartografia e Florestas do Paraná (ITCF), em convênio que também envolveu o Ministério Público, e contava com "o apoio das Prefeituras, dos proprietários rurais e outras instituições".

Como a bibliografia referente não foi citada pelos autores (talvez pelo modo informal que vieram a conhecer tal experiência, aparentemente comunicação pessoal), partimos para uma busca bibliográfica que explicitasse e descrevesse a metodologia desenvolvida pela ADEAM.

Nos anais do $6^{\circ}$ Congresso Florestal Brasileiro encontramos 2 referências à experiência citada, porém desconectadas entre si. A primeira descreve o trabalho de reflorestamento da mata ciliar, desenvolvido pela Itaipú Binacional nas margens de seu reservatório (Müller et al., 1990), e não cita qualquer envolvimento com a ADEAM ou ITCF. A segunda descreve de forma detalhada a metodologia do trabalho da ADEAM na reposição de matas ciliares, em parceria com o ITCF e as Prefeituras, mas o trabalho se desenvolve em municipios do norte do Estado, e não no reservatório da Itaipú (Nadolny \& Contar, 1990). Estaremos mais atentos, portanto, à segunda, que evidencia ser a fonte de inspiração à metodologia de trabalho que se escolheu para a atuação do Consórcio. 
Os trabalho de 'reposição das matas ciliares' iniciaram em fevereiro de 1988, com a parceria da ADEAM e ITCF em municípios do norte do Paraná (Marialva, Itambé, Floresta e Maringá).

"Os proprietários de áreas cortadas por cursos d'água foram notificados acerca da obrigatoriedade da manutenção e recuperação das matas ciliares. Esta experiência inicial resultou na formulação de uma metodologia de ação adaptada à realidade da região trabalhada, onde várias ações integradas são realizadas em etapas. $\mathrm{O}$ objetivo final é a reposição das florestas ao longo dos rios que tiverem suas margens desmatadas e a manutenção das mesmas onde ainda existem." (Nadolny \& Contar, 1990).

Quanto aos fundamentos legais, os autores colocam ênfase na 'função social da propriedade', definida pelo Estatuto da Terra (Lei 4.504 de 30/11/64), que deixaria muito claro o compromisso de conservação dos recursos naturais, do respeito ao meio ambiente. Pelo Código Florestal, chamam à atenção o 'caráter público das florestas protetoras' ("bens de interesse comum a todos os habitantes do país"), o que por si já justificaria as ações contra aqueles que causassem 'abusos perpetrados em ofensa ao patrimônio florístico'. Culpam as autoridades florestais por facilitarem "a ação de proprietários rurais que se sentiram no direito de abater, sem o menor critério, as matas existentes em seus imóveis, mesmo aquelas situadas nas encostas de morros e margens de rios", diante da falta de medidas mais enérgicas.

Ressaltam a importância dos 'movimentos ecológicos', da instituição da Política Nacional do Meio Ambiente (que colocou o Ministério Público na 'condição de guardião do meio ambiente', criou o RIMA, e consagrou o princípio da 'culpa objetiva' frente à responsabilidade do agente de delitos contra o meio ambiente). Defendem que os recursos naturais da propriedade...

"(...) assumem o caráter de um bem público para efeito de proteção legal e, portanto sujeita a sua exploração ao que convém à saúde do meio ambiente, não mais vinculada essa exploração ao exclusivo interesse do dono da terra. E mais: que doravante qualquer um do povo, mediante 
representação ao Promotor de Justiça, pode exigir do responsável por danos ao patrimônio natural a sua reparação" (Nadolny \& Contar, 1990).

Segundo os autores, a ação civil pública foi disciplinada pela lei 7.347 (lei dos direitos difusos), que possibilitou que esta possa "ser acionada pelas entidades preservacionistas e outras pessoas jurídicas na defesa do meio ambiente e do consumidor (...) ela é via processual para o exercício dos direitos do cidadão a um meio ambiente sadio.(...) todos têm direito ao equilíbrio ambiental e que a faculdade de exigir a reparação do dano ecológico passa a ser matéria de ordem pública."

Sobre a obrigatoriedade legal do proprietário (que cometeu a contravenção penal) recompor a mata ciliar:

"Com a utilização indevida surge a infração à lei, e com ela a obrigação irrecusável de recompor ao estado anterior à vegetação ali outrora existente, a teor do que dispõe a já citada lei 6.938:

Sem obstar a aplicação das penalidades previstas neste artigo, é o poluidor obrigado, independentemente da existência de culpa, a indenizar ou reparar os danos causados ao meio ambiente e a terceiros afetados por sua atividade" (art. 14, IV, § 10)" (Nadolny \& Contar, 1990).

E concluem, numa colocação que evidencia as vantagens dessa via, em termos de custos e prazos:

"Foi, pois, estribado basicamente nas leis 4.771 de 15 de setembro de 1965, alterada pela lei 7.803 de 8 de julho de 1989, 6.938, de 31 de agosto de 1981 e 7.347, de 24 de julho de 1985 que o trabalho conjunto do Instituto de Terras, Cartografia e Florestas e ADEAM - Associação de Defesa e Educação Ambiental de Maringá, provou ser possível o reflorestamento de extensas áreas marginais aos cursos d'água a custos inexpressivos, com resultados a curto prazo." (Nadolny \& Contar, 1990).

O artigo denota a forte rotulação dos proprietários como os agressores do meio ambiente, que inescrupulosamente, pensando apenas em 
seu bem-estar e lucros, desprezou os recursos naturais de sua propriedade. Por outro lado, a ADEAM e ITCF aparecem como instituições ambientalistas, força do próprio movimento ecológico:

"Durante a implantação do programa alguns grandes proprietários se mostraram resistentes e impermeáveis à mensagem preservacionista levada pelos agentes florestais do ITCF, o que conduziu à instauração, pela ADEAM, de numerosas representações perante o Promotor Público contra os recalcitrantes."

As etapas de ação descritas, demonstram grande semelhança ao contexto metodológico que se desenvolveu na microbacia do ribeirão Forquilha, indicando a grande adesão da equipe do Consórcio a esta experiência (escolha das bacias hidrográficas e rios a serem trabalhados, produção das mudas florestais, vistorias nas propriedades e cadastramento, plantio e tratos culturais, revistoria, ações civis públicas). Gostariamos de destacar a abordagem educativa que pretenderam os autores na etapa das vistorias:

"Nesta etapa o contato do técnico vistoriador com o proprietário ou encarregado tem um caráter explicativo e educativo, a fim de convencer os mesmos sobre a importância da manutenção das florestas nas margens dos rios. O sucesso do trabalho depende em grande parte deste primeiro contato e da forma como ele acontece e portanto, a obrigatoriedade do plantio, quando for o caso, deve servir apenas como amparo legal contra os proprietários resistentes." (Nadolny \& Contar, 1990).

Interessantes são também os principais problemas encontrados no trabalho de campo e as conclusões dos autores. Destacam a importância na detecção dos problemas que foram sendo levantados, o que teria permitido soluções parciais ao longo dos trabalhos. A revistoria teria, então, esse papel adicional de avaliação do andamento das ações, possibilitando a mudança de estratégia e adequação da atuação dos órgãos e técnicos envolvidos. Ainda 
assim surgiram 'dificuldades específicas', que são descritas de modo a preparar os possiveis multiplicadores dessa metodologia:

a) Plantio com espécies não recomendadas. Exemplo: espécies muito agressivas consorciadas com espécies de crescimento muito lento, aumentando a mortalidade. A solução estaria no uso intensivo de espécies nativas.

b) Fatores ambientais adversos. Exs.: geadas, secas, enxurradas e solos encharcados. A solução seria o plantio em épocas propícias e o uso de espécies resistentes a esses fatores.

c) Baixa qualidade das mudas. Solução: perfeito planejamento de produção e rigoroso controle de estoque. Mas..."é necessário esclarecer que o padrão de qualidade de mudas florestais de espécies nativas ainda é quase desconhecido, havendo necessidade e pesquisas neste sentido".

d) Concorrência com pastagens. "Considerando a dificuldade do proprietário em promover coroamentos, capinas e roçadas muito freqüentes a fim de evitar perdas, uma forma de diminuir o prejuízo ao plantio é o uso de mudas de espécies agressivas, além de caracteristicamente heliófitas e pioneiras, com altura acima de $30 \mathrm{~cm}$, visando favorecer o desenvolvimento inicial do plantio".

e) Consorciação com poucas espécies. "A solução deste problema pode ser obtida através de esclarecimentos destes aspectos junto ao proprietário e da oferta de mudas de várias espécies nos viveiros envolvidos".

Concluem indicando a necessidade de mais pesquisa:

"No atual estágio dos trabalhos, pesquisas devem ser efetuadas no sentido de definir mais detalhadamente as espécies para uso prioritário nos reflorestamentos e adensamentos das margens dos rios e o padrão de qualidade das mudas utilizadas, bem como forças de ação que motivem e agilizem uma maior participação dos proprietários envolvidos neste trabalho". 
Parece nítida a influência deste conhecimento sobre a metodologia de trabalho que foi reproduzida para o contexto de Capivari. No entanto, não houve maior empenho em reconstruí-la num processo comunicativo com os proprietários rurais da microbacia do Forquilha. 


\subsubsection{Projetos ambientais no desenvolvimento rural}

$\mathrm{Na}$ tentativa de trazer novas contribuições ao contexto da conservação ambiental no meio rural, colecionamos aqui - resumidamente algumas experiências e metodologias que julgamos possam vir a contribuir para a ampliação de objetivos e aperfeiçoamento de estratégias de ações que se desenvolvem nesse contexto. Os resumos aqui apresentados também querem exemplificar a grande variedade de abordagens que podemos encontrar nos vários projetos.

Programa de reflorestamento da Mata Ciliar do Reservatório da Itaipú Binacional (1979-1989).

(Müller et al., 1990)

Trabalho que teve mais de dez anos de duração, visava viabilizar o plantio de aproximadamente $28 \mathrm{mil} \mathrm{ha,} \mathrm{nas} \mathrm{margens} \mathrm{do} \mathrm{reservatório,} \mathrm{em}$ prosseguimento ao Plano Básico de Conservação do Meio Ambiente, elaborado antes da implantação do Canteiro de Obras, em 1975. Foi realizado reconhecimento ambiental da área afetada (águas, florestas, fauna, saúde da população local, clima, aspectos sócio-culturais) e Inventário Florestal.

"De 1979 a 1982 foi implantada a Cortina Florestal demarcando a área da Faixa de Proteção (...) No ano de 93 foi iniciado o reflorestamento consorciado através dos agricultores lindeiros às áreas da ITAIPU BINACIONAL".

Implantaram-se os viveiros de mudas, e os marcos de concreto (definindo a poligonal que envolve a APP). Por razões sociais, técnicoeconômicas e culturais, foi adotada a agrossilvicultura, num modelo consorciado de reflorestamento, desenvolvido pelos agricultores 
(aproximadamente 7.500), com plantio de 11,5 milhões de mudas (pegamento de apenas $50 \%$ ), quando eram estabelecidos Termos de Compromisso (foram assinados 1.400 termos): os agricultores plantariam as mudas, conforme projeto técnico, e desenvolveriam cultivos agrícolas nas entrelinhas por prazo determinado. Estariam, assim, supostamente zelando pelas árvores. 0 espaçamento adotado foi de $8 \mathrm{~m}^{2}$ por muda, de modo a permitir a agricultura intercalar.

Como os resultados foram muito variados (em termos de plantios, devido à baixa taxa de pegamento), seguiu-se a essa etapa reflorestamentos heterogêneos através de empreiteiras contratadas.

\section{Projeto de Recomposição da Vegetação Ciliar na Microbacia Hidrográfica do Ribeirão Cachoeirinha - Iracemápolis/SP (início em 1987). (Crestana et al., 1992)}

O trabalho consistiu, inicialmente em arborizar uma faixa marginal de $50 \mathrm{~m}$ de largura da represa principal (de 3 existentes).

A parceria envolveu Prefeitura Municipal, Usina Iracema, Secretaria da Agricultura e Abastecimento do Estado (CATI: DEXTRU, DIRA, Del. Agrícola de Limeira, Casa da Agricultura e Iracemápolis), o Instituto Agronômico de Campinas, UNICAMP, ESALQ/USP, DAEE, IBDF, CESP, Parque Ecológico do Tietê e Polícia Florestal.

Realizou-se levantamento florístico e fitossociológico nas proximidades, elevou-se o dique em 2,5 metros (necessidade de ampliação da capacidade de armazenamento de água); criaram uma lei municipal desapropriando áreas das margens.

O Plano Diretor de Uso e Manejo propunha (1992):

- A recuperação da matéria orgânica do solo (reduzindo queimadas e usando bagacilho e vinhaça, adubação verde, adubação (comum) e calagem;

- O incentivo ao preparo reduzido do solo ou plantio direto; 
- O cultivo da cana em áreas com declividade inferior a 16\%;

- O plantio de culturas em nível e terraceadas.

\section{Programa Estadual de Microbacias Hidrográficas - SP (1993)} (Bertolini et al., 1993)

O trabaliho que vem sendo desenvolvido pela CATI, em microbacias hidrográficas, "propõe o desenvolvimento agrícola em consonância com o meio ambiente, ou seja, aumentar a produção e a produtividade sem degradar os recursos naturais (...) Através do Programa Estadual de Microbacias Hidrográfica os Governos Estadual e Municipal e as associações de agricultores estão iniciando um trabalho visando adequar o aumento da produção de alimentos para atender ao consumo intemo e gerar excedentes para o mercado externo, melhorando o padrão de vida do agricultor e ao mesmo tempo utilizando de modo racional e integrado os recursos naturais do solo, da água, flora e fauna."

Têm o objetivo de controlar a erosão hídrica e reverter o processo de degradação dos recursos naturais renováveis do estado, com base em alternativas tecnológicas que aumentem a produção vegetal, a produtividade agrícola e a renda líquida do produtor, promovendo o desenvolvimento rural integrado da agricultura paulista.

Propõem, então, que as ações a serem desenvolvidas em uma microbacia hidrográfica devam objetivar:

- uso e o manejo corretos (racionais) dos recursos naturais;

- aumento da rentabilidade das explorações agrosilvopastoris;

- A melhoria das condições de tráfego da estradas;

- Melhores condições de vida da população, graças às melhores rendas, maiores oportunidades de lazer, ensino, assistência médica e dentária;

- Maximização das rendas municipais (aumento do recolhimento de impostos e redução de custos de manutenção); 
Os critérios para seleção das microbacias a serem trabalhadas seriam:

- Áreas de maior concentração de pequenos produtores

- Significativa produção de alimentos básicos

- Áreas de assentamento rural

- Áreas de desenvolvimento de projetos de irrigação por pequenos agricultores

- Áreas onde a prefeitura e os produtores rurais queiram investir recursos e esforços no Programa

- Áreas críticas ou de nascentes com problemas de desmatamento

- Áreas onde os recursos naturais renováveis estejam muito degradados

- Áreas onde já se desenvolvem trabalhos de conservação de solos, da água ou outros recursos naturais

- Onde estejam disponiveis recursos humanos e materiais para o Projeto

- Bacias compartilhadas com outros municípios vizinhos, a serem trabalhadas de forma integrada.

Diálogo Ambiental em Comunidades Rurais (DAC), da Costa Rica (19911995)

(Barrantes et al., 1997)

Trata-se de um projeto desenvolvido pela Organización para Estudios Tropicales (OET), entre 91 e 95, dentro do contexto de um Programa de Politica Ambiental, dirigido a decisores de várias categorias, que têm em comum sua capacidade de influenciar o uso e conservação dos recursos naturais nos países tropicais e de melhorar a qualidade de vida de seus habitantes. É financiado pela Fundação Ford, e conta com o apoio da Universidade Nacional (UNA, Heredia, Costa Rica), do Word Resources Institute (WRI, Washington D.C., EUA). 
Os pressupostos básicos da metodologia de diálogo ambiental, seriam:

1) nada se exclui da possibilidade de se dialogar;

2) há liberdade de expressão dos e entre os participantes;

3) é inquestionável que a conservação dos recursos naturais é importante para manter e melhorar a qualidade de vida e o bem-estar da comunidade; assim mesmo, este tema contempla também aspectos sociais e econômicos;

4) os agricultores e agricultoras podem e devem desenvolver um papel mais efetivo (como protagonistas) nos processos de desenvolvimento e conservação;

5) a participação ativa aumento o sentido de poder dos grupos de base e organizações locais, melhorando sua auto-imagem, capacidade e autogestão, o que incide positivamente na tomada de decisões;

6) As organizações locais, ao se integrarem ao processo, transformam-se em multiplicadores.

\section{Projeto de Educação Ambiental com os Proprietários rurais Confrontantes com o Parque Nacional do Caparaó (ES)}

(Morais \& De Paiva, 1992)

Através da extensão florestal, o projeto visa transmitir informações básicas sobre a importância da manutenção dos recursos naturais renováveis para os proprietários rurais confrontantes com o Parque Nacional do Caparaó. Busca o envolvimento dos órgãos de assistência técnica rural, prefeituras municipais e IBAMA.

Destaca-se o modelo de extensão florestal escolhido, cujas características principais seriam:

a) tornar a comunicação rural um verdadeiro processo de interação social com o crescimento humano do extensionista e do agricultor; 
b) integrar a comunicação aos demais aspectos da realidade rural, apresentando a tecnologia sem mística e não caindo no tecnicismo

c) fortalecer, junto aos agricultores, o direito de dialogarem e diagnosticarem sua própria realidade, sem o domínio da cultura urbanizadora.

\section{O Trabalho da Associação de Preservação do Meio Ambiente do Alto Vale do Itajaí - APREMAVI (início em 1987)}

(Schäffer et al., 1997)

Fundada em 1987 (Ibirama, SC), é uma sociedade civil sem fins lucrativos que tem como objetivo "trabalhar pela defesa e recuperação do meio ambiente, dos bens e valores culturais e pela melhoria da qualidade de vida humana". Surgiu pela preocupação com o avanço das derrubadas de Mata Atlântica pelas madeireiras da região. Atualmente conta com 300 sócios, entre agricultores, professores, bancários, estudantes, empresários, médicos, advogados, biólogos entre outros.

"A defesa e recuperação da Mata Atlântica sempre fọi o carro chefe das ações da APREMAVI" desde sua fundação. Participa e já representou o movimento ecológico em diferentes comissões e organizações a nível estadual e nacional.

Participa do Conselho Nacional da Reserva da Biosfera, onde "o objetivo principal é a conservação da biodiversidade e a educação ambiental. Também visa promover o desenvolvimento sustentado, a participação da população e o fomento e a difusão do conhecimento científico. Presta também, colaboração no aprimoramento da legislação e de políticas públicas na área da Mata Atlântica".

A instituição vem se destacando pelo grande envolvimento que desenvolve com as comunidades rurais em trabalhos educativos, mas também pelos resultados efetivos em termos de plantios de matas ciliares e de outras florestas. 


\section{"Paraná Rural" - Programa Estadual de Manejo e Conservação do Solo em Microbacias (1989-1996) \\ (Resende, 1996)}

Com base no artigo de José Resende no Suplemento Agrícola do jornal O Estado de São Paulo, trazemos aqui algumas informações sobre esse programa.

Desde a década de 70 o Paraná vem tentando desenvolver ações de manejo e conservação do solo, mas que teriam sido mal-sucedidas porque se resumiram ao controle do escorrimento superficial das águas.

"O trabalho era calcado em 'estratégias de pressão' (o crédito, por exemplo, só era liberado ao produtor que fizesse conservação do solo), ou então baseava-se quase que exclusivamente em práticas mecânicas, como o terraceamento em desnivel, em propriedades isoladas".

Os fatores que contribuíam para a degradação dos recursos naturais eram:

1) uso intensivo e inadequado do solo;

2) o tipo de colonização ("divisão fundiária vindo do espigão para o fundo do vale");

3) as estradas construídas nos espigões e divisas.

Conseqüências: erosão, compactação, redução da fertilidade do solo e da produtividade agrícola, perdas crescentes de solo e assoreamento dos rios. Este Programa (que contou com o apoio financeiro do Banco Mundial BIRD), que veio então como resposta a esse quadro, "pretendia mudar a mentalidade dos produtores". Sendo os problemas comuns a todos os agricultores, entendeu-se a necessidade de maior interação e estímulo às práticas comuns.

"(...) foram-se resolvendo os problemas relativos às estradas, abastecimento comunitário, plantadeira de plantio direto, distribuidores de 
esterco e de calcário", com o incentivo de aquisições de equipamentos comunitários $(7,2 \mathrm{mil})$.

Entre os benefícios do projeto, são citados "o aumento da produção e da produtividade e a melhoria da qualidade da água", "a readequação de 49 mil quilômetros de estradas" e o estímulo à "organização dos agricultores em torno dos interesses comuns". Curiosamente, em relação aos níveis de adoção de tecnologia, o mais baixo foi o da 'cerca de proteção de mananciais' (43\%), que entendemos ser uma forma de isolamento das APPs.

Apenas para citar alguns indicadores desses benefícios:

Município de Tupãssi: aumento de nutrientes no solo, e conseqüente aumento na produtividade (de $59 \%$ na cultura do milho);

Região de Pato Branco: aumento de $58,2 \%$ na área média construída (infra-estrutura produtiva); aumento de $18 \%$ para $71 \%$ na adoção e implementação de terraceamento; aumento de $60 \%$ na área média conservada; incremento de $8 \%$ no número de tratores. "A média de animais de tração aumentou $3,8 \%$, matrizes bovinas passaram de 5 para 7 cabeças. (...) a renda bruta disponivel da mão-de-obra familiar passou de US\$ 3 mil por equivalente homem/ano para US $\$ 5.475$ no período do projeto. (...) o número de congeladores e de fogões evoluiu $5,5 \%$ e $9,7 \%$ respectivamente".

O programa está estruturado sobre 4 estratégias:

1) cobertura do solo

2) aumento da infiltração da água no solo

3) redução do escorrimento superficial

4) e controle da poluição

Sua operacionalização se deu através dos Conselhos Municipais de Manejo e Conservação do Solo (formados por representantes de cooperativas, sindicatos, associações, empresas de planejamento, técnicos da Emater, prefeituras e igreja), Comissões Regionais (técnicos das Secretarias da Agricultura, Transportes e Meio Ambiente) e Unidade de Gerenciamento do Projeto (vinculada ao secretário da Agricultura). 
A estratégia de comunicação foram os 'dias de campo' e excursões para as regiões onde já existiam resultados efetivos, o que os motivou muito a participar do programa, segundo Resende.

\subsection{O Consórcio Intermunicipal da Bacia dos rios Piracicaba e Capivari e o contexto do Programa de Reflorestamento Ciliar}

Incentivado por Queda', e provocado por Barros et al. (1998: p. 27) que apontam a necessidade de:

"(...) aprender a utilizar este tão útil instrumento da psicologia social, a análise institucional, proporcionando subsídios para uma visão crítica diante de propostas institucionais com discursos ditos inovadores e transformadores, atendendo para o fato de que as palavras podem ser manipuladas de forma a tomar outras interpretações, ou ainda terem o mesmo sentido, sem serem utilizadas para promover mudanças estruturais",

procuro contextualizar neste capítulo a atuação do Consórcio e de seu Programa.

\subsubsection{Justificativas históricas}

Segundo Sebastianes (1992), a crescente degradação da bacia do rio Piracicaba foi sendo percebida pelas populações aí estabelecidas de modo diferenciado, e em diferentes momentos: ribeirinhos se defrontando com a mortalidade dos peixes, administrações públicas e empresários preocupados

\footnotetext{
${ }^{1}$ QUEDA, O. (Departamento de Economia e Sociologia Rural da ESALQ/USP). Comunicação pessoal, 1998.
} 
com os custos crescentes da despoluição, movimentos populares em passeatas (a partir de 1977), manifestos e até enterro simbólico do rio. Conforme o autor, a indignação desses vários setores da comunidade se materializou na elaboração da Carta de Reivindicações ao Governo Orestes Quércia, dando corpo à Campanha Ano 2000 - Redenção Ecológica da Bacia do Rio Piracicaba (1985), coordenada pela Divisão do Meio Ambiente da Associação dos Engenheiros e Arquitetos de Piracicaba (que compõem o Conselho Coordenador das Entidades Civis de Piracicaba)

"Esta Carta foi fruto de inúmeros debates e reuniões, não só em Piracicaba, mas também em cidades próximas. Nesta época, começou a ganhar força o sentimento regional e a necessidade de integração dos municipios a fim de resolver problemas ambientais comuns. As propostas transcritas nas reivindicações 19 e 31 do documento citado traduzem muito bem isto: criação de um organismo intermunicipal, eleito e representante de um Conselho Diretor de Prefeitos da Bacia; que os recursos sejam recolhidos ao organismo intermunicipal da Bacia do rio Piracicaba" (Consórcio, 1998: p.13).

Os reflorestamentos ciliares já estavam contemplados entre as prioridades, descritas na Reivindicação 30 :

"que a aplicação dos recursos obedeçam, pela ordem, as seguintes prioridades:

a) tratamento de esgotos comunitários;

b) reflorestamento de áreas de preservação permanente;

c) financiamento de projetos de incentivo à pesquisa;

d) financiamento de cursos destinados à educação e à conscientização ambiental das comunidades da Bacia;

e) financiamento de concursos abordando temas ecológicos da Bacia." 


\subsubsection{Organização do Consórcio}

Doze prefeitos assinaram a ata de fundação do Consórcio, em 1989, quando ainda não estava incluída a Bacia do rio Capivari. Tal inclusão se deu em função do lançamento de $50 \%$ dos esgotos de Campinas na bacia do Capivari, e porque grande parte da área urbanizada da cidade localiza-se nesta bacia (Consórcio, 1998).

O Consórcio intermunicipal das Bacias dos rios Piracicaba e Capivari estava composto, então, por quatro órgãos funcionais:

- Conselho de Municípios (órgão deliberativo máximo);

- Conselho Fiscal;

- Secretaria Executiva (equipe técnica e administrativa) e

- Plenária de entidades (órgão consultivo, por representantes da sociedade civil).

$\mathrm{Na}$ organização da equipe técnica da Secretaria Executiva, optouse por manter uma equipe pequena (de coordenadores), e contratar os principais projetos e consultores de acordo com as demandas. Descartou-se a opção por equipes de especialistas de várias áreas para executar os trabalhos (Consórcio, 1998).

\subsubsection{Diagnósticos sobre a degradação dos recursos hídricos}

A leitura que tal equipe fazia da qualidade ambiental e das medidas a serem tomadas, podem ser encontradas no Plano de Atuação e Orçamento de 1991 (Monticelli \& Barros, 1991: p.3):

"As vazões dos rios nos períodos de seca são baixas e a carga poluidora tão alta que os tratamentos d'água em algumas cidades estão seriamente ameaçados. A própria população começa a se organizar para reivindicar não apenas melhor qualidade de água potável, mas também a recuperação e a preservação dos rios e das matas ciliares.(...) As 
soluções exigem medidas de integração municipal, apoio das instituições estaduais e federais e participação do empresariado e da população local nos programas preconizados.(...) A contínua poluição da Bacia do Piracicaba e Capivari afetará mais de 10 milhões de habitantes e poderá significar a necessidade de bilhões de dólares em investimentos para novos sistemas de captação e tratamento de água, caso o atual nivel de degradação não seja contido".

Em síntese, as principais realização da primeira gestão do Consórcio foram:

1. "Início das negociações com o Banco Mundial, visando a um amplo programa de investimentos em obras e ações ambientais, para a recuperação e proteção das Bacias dos rios Piracicaba e Capivari, mais tarde estendidas também à Bacia do rio Jundiaí";

2. "Proposição da criação de Agência de Bacia Hidrográfica ${ }^{2}$ e defesa de uma política de gestão de recursos hídricos descentralizada e que atenda aos interesses da região";

3. "Convênio com o DAEE, que permitiu aplicação de US\$3 milhões em estudos e projetos, principalmente de estações de tratamento de esgoto, $50 \%$ provenientes de cada parceiro".

No Plano de Atuação para 1991, constavam as ações:

a) Convênio DAEE - Consórcio

b) Sub-bacias do rio Corumbataí

c) Apoio aos municípios

d) Equacionamento de recursos financeiros

e) Reflorestamento Ciliar

\footnotetext{
${ }^{2}$ órgão que, entre outras atribuições, administraria os recursos advindos da operacionalização do sistema poluidor-pagador, e da futura cobrança pelo uso da água, a exemplo da estrutura de gerenciamento existente na França. Um panorama amplo, histórico e mais aprofundado pode ser encontrado na publicação Semana de Debates sobre Recursos Hídricos e Meio Ambiente (Consórcio Intemunicipal das Bacias dos Rios Piracicaba e Capivari/ DAEE/ FUNDAP, 1992).
} 
f) Outras atividades

Entre 91 e 92, o Consórcio arrecadava e aplicava cerca de US $\$ 800.000 / a n o$, sendo que US\$600.000 em investimentos (Consórcio, 1998).

Os três grupos de programas priorizados esclarecem a concepção do Consórcio, quanto às soluções à problemática levantada:

1. Programa de Saneamento Ambiental

1.1. sub-programa Recursos Hídricos

1.1.1. Abastecimento Urbano

1.1.2. Mananciais

1.1.3. Uso das Águas

1.1.4. Regularização de vazões

1.2. sub-programa Recuperação Ambiental

1.2.1. Efluentes urbanos

1.2.2. Resíduos sólidos

1.2.3. Efluentes industriais

1.2.4. Microbacias

1.3. sub-programa Análise Econômica-Financeira Social;

1.3.1. Cronograma Físico-Financeiro

1.3.2. Financiamento

1.3.3. Recuperação dos Investimentos

1.3.4. Análise custo-benefício

2. Programa de Planejamento Regional;

2.1. Disciplinamento da atividade econômica

2.2. Controle e monitoramento

2.3. Desenvolvimento tecnológico

3. Programa de Gestão dos Recursos e do Meio Ambiente;

3.1. Gestão de bacias hidrográficas

3.2. Cobrança pelo uso das águas

3.3. Municípios atingidos por reservatórios 
Os itens Mananciais e Microbacias foram destacados por razões diferentes. O primeiro por abranger o Programa de Reflorestamento Ciliar aqui estudado; e o segundo por não ter sido desenvolvido na microbacia estudada, embora trabalhe questões mais explicitamente do interesse dos proprietários rurais, e que poderiam ter incrementado o nível de adesão/participação daqueles, como mostra a tabela 1:

\begin{tabular}{|c|c|c|c|}
\hline ITEM & OBJETIVO & $\begin{array}{l}\text { DESCRIÇÃOO } \\
\text { SUCINTA }\end{array}$ & $\begin{array}{l}\text { RESULTADOS } \\
\text { ESPERADOS }\end{array}$ \\
\hline Mananciais & $\begin{array}{l}\text { Proteção dos } \\
\text { Mananciais atuais e } \\
\text { futuros }\end{array}$ & $\begin{array}{l}\text { Leis de Proteção } \\
\text { ambiental, campanhas } \\
\text { de esclarecimentos, } \\
\text { zoneamento, replantio } \\
\text { e manutenção das } \\
\text { matas, fiscalização, } \\
\text { restrições à ocupação, } \\
\text { legislação municipal }\end{array}$ & $\begin{array}{l}\text { Água de qualidade que } \\
\text { permita tratamento } \\
\text { convencional. } \\
\text { Recomposição da } \\
\text { fauna e flora. }\end{array}$ \\
\hline Microbacias & $\begin{array}{l}\text { Proteção dos } \\
\text { mananciais e do solo. } \\
\text { Aumento da } \\
\text { produtividade agrícola }\end{array}$ & $\begin{array}{l}\text { Terraceamento, } \\
\text { combate à erosão, } \\
\text { técnicas agrícolas } \\
\text { adequadas. }\end{array}$ & \begin{tabular}{|l|} 
Redução do \\
assoreamento e da \\
poluição por \\
agrotóxicos. Aumento \\
da produtividade \\
agricola. \\
\end{tabular} \\
\hline
\end{tabular}

Tabela 1. Descrição de duas das frentes de ação elencadas pelo Consórcio como prioritárias (adaptado de Monticelli \& Barros,1991).

Numa primeira avaliação do programa na microbacia do ribeirão Forquilha, ficariamos mais restritos a alguns aspectos gerais mencionados no artigo que não foram realmente desenvolvidos. Um ponto importante foi o não envolvimento da Casa da Agricultura, cuja participação ficou restrita ao fornecimento do 'Plano de Manejo da Microbacia do Ribeirão Forquilha' (São Paulo,1990) e dos mapas das microbacias. Ainda assim, o Plano de Manejo foi parcialmente considerado, como vemos a seguir.

O levantamento realizado para a elaboração desse Plano, considerava como 'Pontos de Estrangulamento' na microbacia: 
"Os agricultores têm necessidade de uma assistência técnica mais efetiva na preservação dos recursos naturais renováveis, no uso adequado de defensivos, na condução de suas lavouras, na conservação de suas máquinas e implementos agrícolas, na renovação se seus canaviais com variedades resistentes ao carvão, na recomposição da flora e fauna, pois são estes os pontos que encontram mais dificuldade" (São Paulo, 1990: p. $6)$.

Os principais problemas levantados, na época, foram:

a) arrastamento das camadas superficiais do solo, com perda de fertilidade;

b) arrastamento de fertilizantes e corretivos, com menor produtividade das culturas e mais gastos com adubação;

c) assoreamento dos riachos, ribeirão e represa;

d) poluição dos mananciais, ribeirão e represa pelo uso inadequado de defensivos;

E Climinuição da qualidade de água servida à população e dificuldades no controle da boa qualidade

f) falta de proteção aos recursos hídricos, pela inexistência de matas ciliares;

g) extinção das espécies nativas, vegetais e animais;

h) queda de produtividade das culturas por falta de orientação adequada;

i) redução do volume de produção e encarecimento dos produtos;

j) dificuldade de manutenção das estradas e carreadores;

k) maior susceptibilidade das culturas às doenças, pelo empobrecimento do solo;

I) dificuldade na obtenção de mão-de-obra especializada.

Consistia em um projeto para captação de recursos, a serem usados por 3 anos, prevendo 3 grupos de atividades:

a) Racionalização do uso do solo

b) Repovoamento da represa

c) Racionalização do manejo do solo 
O levantamento não fornece os dados das conclusões a que chegou, nem a metodologia adotada.

Diante desses pontos, o objetivo geral do Plano (São Paulo, 1990: p.13) era "promover o manejo racional dos recursos naturais renováveis da Bacia Hidrográfica, com vistas a se obter melhoria das condições de vida da população rural e urbana." Seus objetivos específicos eram voltados ao controle da erosão, melhoramento dos solos, aumento da vazão e melhora da qualidade dos recursos hídricos, recomposição das matas ciliares, aumento da renda agrícola (reduzindo gastos e aumentando o volume de produção), melhores condições de tráfego às estradas reduzindo custos de manutenção, e melhor disponibilidade de mão-de-obra especializada

Os técnicos da CATI/Capivari não conseguiram a aprovação do Plano. Mas a equipe do Consórcio teve acesso a ele e recortou dele - segundo a minha intepretação - a leitura que mais lhe interessava na época: os proprietários são uma ameaça à conservação dos recursos hídricos da microbacia, devendo ser persuadidos a abandonar as atividades à beira dos córregos e a implantarem as matas ciliares, sob pena de serem processados.

Analisando mais profundamente os planos de ação da frente de reflorestamento ciliar, encontramos a confirmação das intenções pré-definidas do Consórcio:

"O Consórcio deverá iniciar um programa, em 1991, visando o reflorestamento ciliar, com prioridade para as áreas de mananciais e realizado pelos próprios donos das terras. Para conduzir este programa será feito um convênio com a SOBRADIMA - Sociedade Brasileira de Direito do Meio Ambiente, com os seguintes princípios de atuação:

1) convidar os proprietários das terras ribeirinhas para uma conversa e conscientização da problemática da região. Num primeiro momento solicitar ao proprietário o comprometimento de deixar de plantar até as margens dos rios e, num segundo momento, de replantar a mata ciliar; 
2) entrar com ações na justiça contra os proprietários que não aceitarem ou deixarem de cumprir os acordos, com base na legislação;

3) acompanhar os processos na justiça com intuito de se conseguir o reflorestamento das margens dos rios e não a solução pelo pagamento das multas.

O Consórcio procurará órgãos e instituições públicas e privadas que possam fornecer mudas e apoio técnico para os proprietários que se dispuserem a iniciar reflorestamentos em suas terras às margens dos rios. Contatos que foram iniciados com a CESP - Companhia Energética de São Paulo deverão ser intensificados, visando o aporte de mudas e de assistência técnica" (Monticelli \& Barros, 1991: ps. 20 e 21).

\subsubsection{A estrutura do programa}

Apresento, a estrutura (geral, não apenas para a microbacia do Forquilha) do programa descrita pelos coordenadores da época (que pode ser encontrada em Ricardo e Romani, 1992), e comentada com base nas entrevistas realizadas junto aos proprietários, parceiros e outros envolvidos com o contexto.

Baseado na já citada experiência da ADEAM no norte do Paraná, tal programa buscou inicialmente a parceria das instituições:

a) SOBRADIMA - Sociedade Brasileira e Direito do Meio Ambiente;

b) CESP - Cia. Energética de São Paulo;

c) SMADEPRN - Secretaria do Meio Ambiente - Departamento Estadual de Proteção aos Recursos Naturais;

d) Ministério Público;

e) Policia Florestal e de Mananciais;

f) Fundação Florestal;

g) Casa da Agricultura e

h) Prefeituras.

Em termos de objetivos, dizem os autores: 
"(...) o objetivo final do Programa de Reflorestamento Ciliar na Bacia dos rios Piracicaba e Capivari, se não a curto mas a médio prazo, procura reverter o alto grau de degradação ambiental na região, resguardar a quantidade e a qualidade de água, minimizar os custos do tratamento das águas oferecidas à população, resgatar fauna e flora regionais e despertar uma preocupação cada vez maior na sociedade com relação à qualidade do meio em que se vive, fundamental à sobrevivência da humanidade." (Ricardo e Romani, 1992: p. 140).

Numa primeira etapa, teria sido realizado primeiramente o levantamento cadastral.

"De posse deste cadastro, reuniões são convocadas com o apoio de entidades locais, tais como, Associações, Sindicatos, Cooperativas, com o objetivo de conscientizar aqueles proprietários rurais da importância de se proteger e reflorestar as margens dos cursos d'água que são utilizados para o abastecimento público" (Ricardo e Romani, 1992: p. 137).

Nessas reuniões, cada entidade teria relatado o modo de sua atuação dentro do programa, e colocado aos proprietários suas obrigações quanto à legislação. "São ressaltados, também, os benefícios que o proprietário rural terá com a adesão espontânea ao Programa (...)" (Ricardo e Romani, 1992: p. 137).

Recebem 'gratuitamente':

a) um projeto para a recuperação da área degradada;

b) mudas de espécies nativas necessárias;

c) apoio técnico para a implantação do Projeto de Reflorestamento.

Na segunda etapa, o cadastro é enviado ao DEPRN, que avalia o estado de degradação das áreas e elabora os laudos técnicos. Os proprietários são, então, notificados e convocados a uma reunião, individualmente, "onde serão discutidos com ele, as condições em que se encontram os cursos d'água dentro de sua propriedade e quais as formas propostas de recuperação das áreas" (Ricardo e Romani, 1992: p. 138). 
Estariam presentes: técnicos do Consórcio, DEPRN e CESP. Nessa reunião é apresentado o Termo de Adesão ao programa, onde o proprietário se comprometeria em aderir ao programa e a cumprir a legislação referente (Código Florestal e alterações). A CESP elaboraria, a partir disso, um projeto de reflorestamento, que contemplaria "as características de cada propriedade, um cronograma definido de implantação, com prazo máximo de 02 anos para sua concretização, um detalhamento das espécies a serem utilizadas, quantidade de mudas, normas e técnicas necessárias à sua implantação, entre outras informações de caráter técnico" (Ricardo e Romani, 1992: p. 138).

O proprietário deveria assinar ainda um Termo de Cooperação, com a CESP, para o repasse gratuito das mudas.

A terceira etapa seria o próprio reflorestamento. Uma forma resumida dessas etapas, assim como o modelo de termo de adesão adotado é apresentada na figura 4 .

Sobre a espontaneidade das adesões, relatam os autores:

"Porém, ocorre que nem todos os proprietários lindeiros aos cursos d'água aderem espontaneamente ao Programa. Esses proprietários recebem um tratamento diferenciado, que consiste em encaminhar-se a Polícia Florestal e ao Ministério Público o laudo técnico efetuado pelo DEPRN, para as providências que se fizeram necessárias para o caso em questão. Esses proprietários resistentes deixam de contar com os benefícios que o Programa oferece e passam a arcar com todos os custos daquela recuperação" (Ricardo e Romani, 1992: p. 138).

Há nesse artigo, já, uma avaliação das primeiras dificuldades encontradas (p. 140):

"O caráter inédito do programa gerou inúmeras resistências na medida em que o desconhecimento da legislação é generalizado (...)". Isso estaria, na opinião dos autores, associado ao seguintes fatos: 


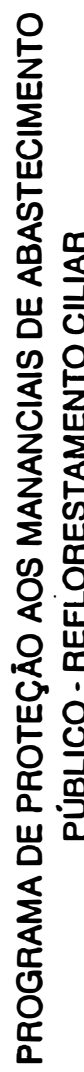

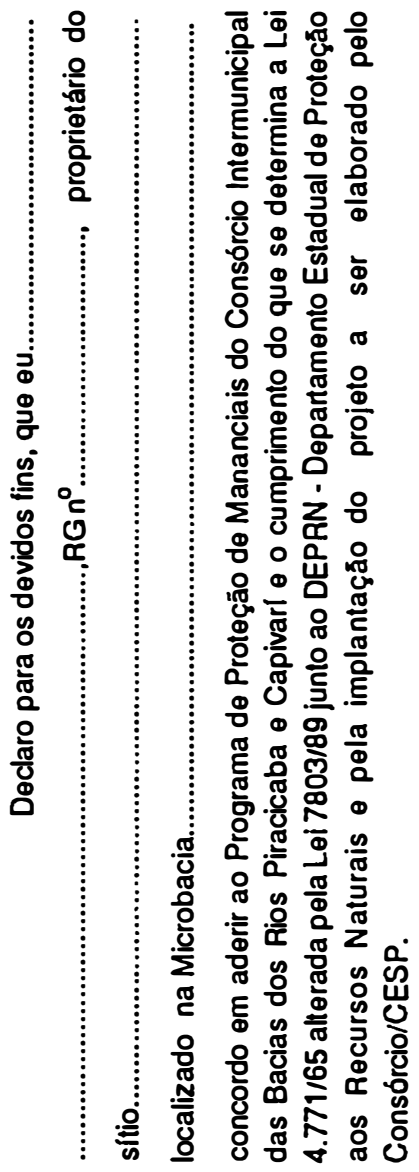

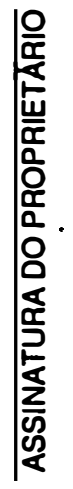

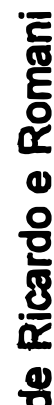

웅

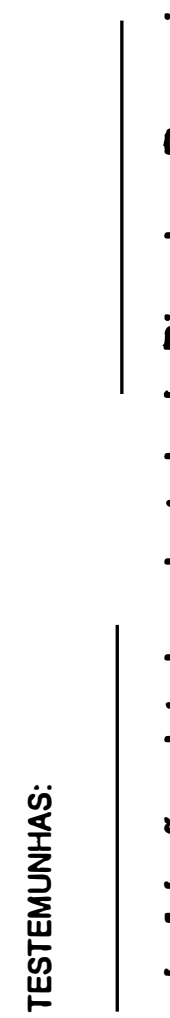

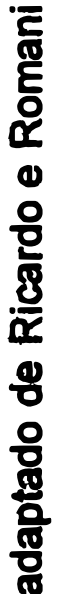

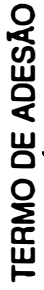

ㅇํำ

101

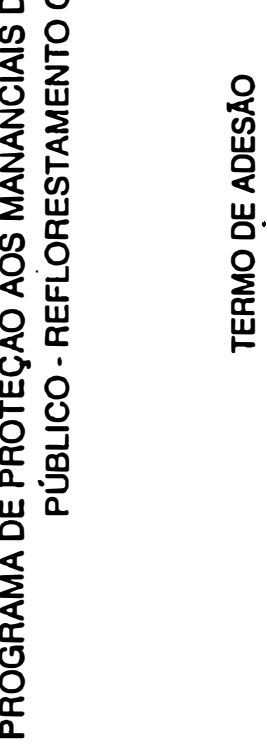

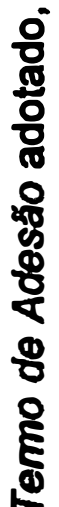

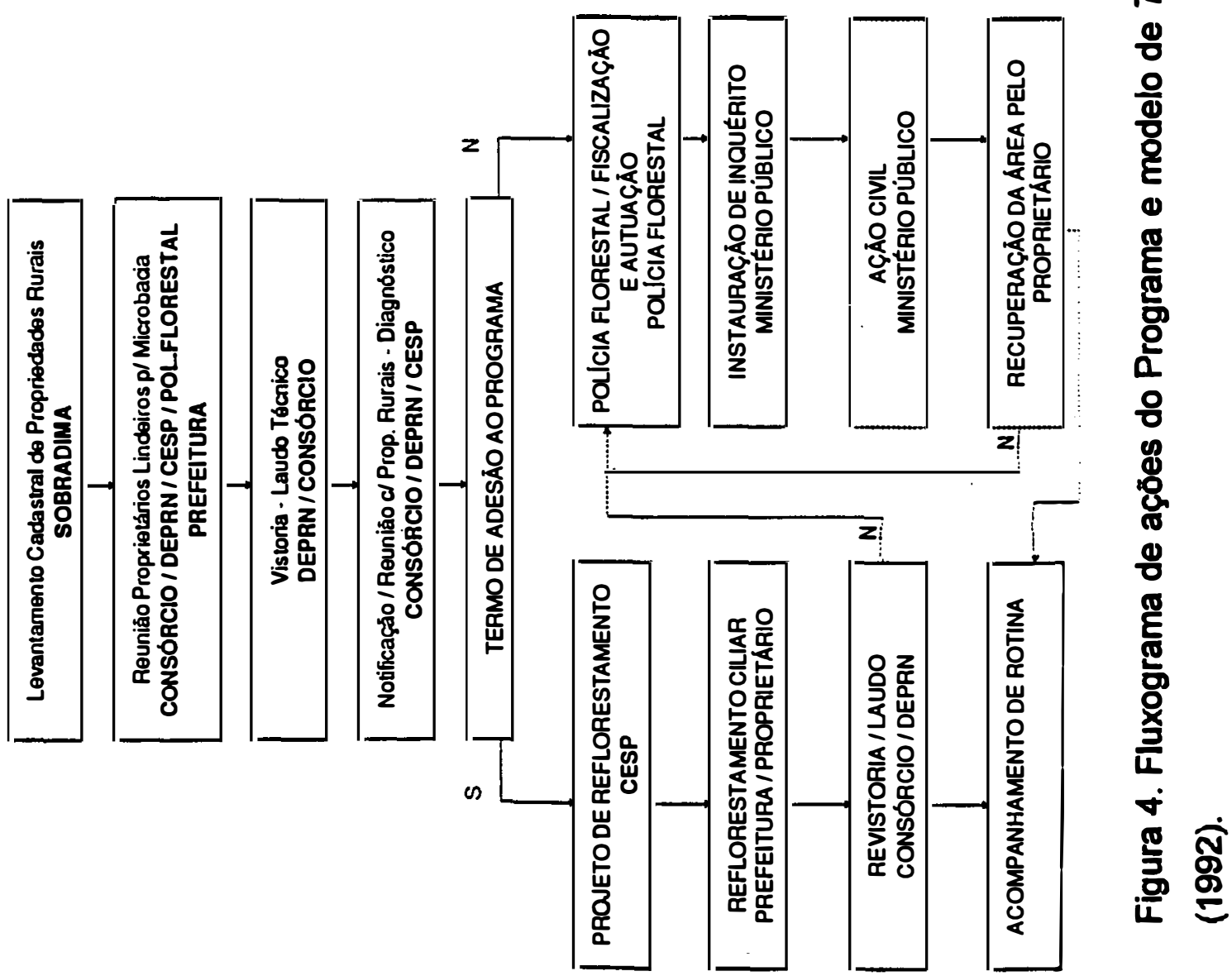


- sociedade, como um todo, não conscientizada para as questões ambientais;

- "interesses econômicos acima da preocupação com a qualidade e vida";

- escassez de recursos humanos e financeiros das administrações públicas (municipal, estadual e federal);

- "processo de descapitalização da sociedade ocasionado pelo refluxo da economia nacional;

- ausência da iniciativa privada entre os parceiros do programa;

- o próprio aprimoramento da metodologia de trabalho eficaz para a execução do Programa no Estado de São Paulo.

As ações que teriam sido desencadeadas, na fala dos autores, frente a estas constatações foram:

a) Estímulo à instalaçāo de viveiros de mudas pelas prefeituras;

b) Incentivo ao desenvolvimento de núcleos de Educação Ambiental locais;

c) Desenvolvimento de cursos sobe recursos hídricos aos assessores municipais e professores de $1^{\circ}$ e $2^{\circ}$ graus;

d) Elaboração de manuais e 'folders' para divulgação e conscientização do trabalho;

e) Articulações institucionais para aumentar a produção de mudas.

Em Capivari, mais precisamente na microbacia do Ribeirão Forquilha, algumas dessas ações parecem ter colaborado para o andamento dos projetos (itens "a" e "e"), enquanto que outras simplesmente não vingaram ("b", "c" e "d"). Em termos gerais, elas parecem não atacar a base das dificuldades elencadas pelos autores.

\subsubsection{Avaliação dos resultados}

Finalizando, entre os "grandes avanços conseguidos pelo Consórcio no período 93-96", estão "a consciência da necessidade de proteção dos mananciais" (Consórcio, 1998): 
"O Consórcio, em parceria com a CESP, prefeituras e DEPRN, conseguiu realizar, até 1996, o plantio de 250 mil árvores de espécies nativas, recompondo cerca de 140 ha de matas ciliares que protegem os mananciais de abastecimento público das cidades de Capivari, Sumaré, Nova Odessa e Saltinho. Mas, mais que realizar o plantio, o mérito deste Programa foi mostrar a importância dos mananciais de abastecimento público, atuais e futuros. (...) Os serviços municipais de água e esgoto, por meio de seus técnicos, e da própria comunidade, passaram a preocuparse não só com a estação de tratamento de água e o sistema de distribuição, mas com os mananciais, com a água bruta. Cada vez mais vem se desenvolvendo uma consciência regional de que a água potável, de boa qualidade, só é possível havendo mananciais protegidos, com um mínimo de qualidade".

Em termos orçamentários, temos os gastos com o reflorestamento ciliar (que são apenas de custeio) planejados no orçamento anual do Consórcio (Monticelli \& Barros,1991, e Monticelli \& Barros,1992):

\section{Em 1991}

A despesa com o reflorestamento ciliar equivale a $2 \%$ da despesa total, e 4,4\% das despesas de custeio.

Das despesas com a pasta Reflorestamento Ciliar, $68 \%$ dos gastos referem-se ao convênio com a SOBRADIMA, e 32\% com assistência técnica para proprietários de terras.

\section{Em 1992}

A despesa com o reflorestamento ciliar equivale a $0,89 \%$ da despesa total, e 2,3\% das despesas de custeio. Do total gasto com o reflorestamento ciliar, 32\% referem-se ao Convênio com a SOBRADIMA, 52\% relativo à assistência técnica para proprietários de terras e $16 \%$ referem-se à educação ambiental. 
Gostaria de ressaltar a inexistência de informações disponiveis a respeito dos itens "assistência técnica para proprietários de terras" e "educação ambiental", contabilizados nas previsões orçamentárias de 91 e 92, com os reflorestamentos ciliares. Não encontrando indícios destas atividades no contexto da microbacia do ribeirão Forquilha, entendo possam ser referentes à outras microbacias, embora isso levante a possibilidade de ter ocorrido tratamento diferenciado, regionalmente.

\subsection{Objetivos da pesquisa}

A busca dessa dissertação, como sugere o título, é compreender a estrutura de ação adotada por um programa voltado à recomposição ciliar criado pelo Consórcio (e desenvolvido conjuntamente com outras instituições parceiras) que, preocupado com a 'conservação ambiental', teve o objetivo de proteger um importante manancial de abastecimento de água para o municipio de Capivari (SP), a microbacia do Ribeirão Forquilha, localizada em área rural. Nesse programa, foi (e continua sendo) fundamental para a efetivação dos plantios, a legislação ambiental referente (Código Florestal) à proibição de uso das áreas de preservação permanente (APPs) - entre as quais está a mata ciliar - obrigando a 'participação' dos proprietários rurais. Interessou, portanto, confrontar algumas das diferentes leituras sobre os temas que compõem o contexto da microbacia estudada, mas também de modo a provocar uma reflexão maior, para a bacia dos rios Piracicaba e Capivari, entendendo o lugar da intervenção educativa, em alguns de seus componentes estruturais - como a comunicação, participação, construção de conhecimento, capacitação para a ação - na atual problemática ambiental.

Tal busca será, então, a de compreender o contexto em que se desenvolveu esse programa, através dos depoimentos dos diferentes 
'participantes' e na bibliografia relacionada, numa avaliação dos caminhos percorridos entre as motivações e as ações, dando voz aos atores que até então não tiveram tal oportunidade nos relatos oficiais: os proprietários rurais. Também busca analisar alguns pontos de estrangulamento da participação nas ações de reflorestamento ciliar, assim como os 'vazios' criados pela falta de avaliação crítica dos resultados (por falta de interesse ou por opção metodológica), onde podem estar boas soluções para o incremento das ações de revegetação no Estado.

Por se tratar de um problema ambiental já tão comum no nosso contexto paulista (a degradação dos recursos hídricos), e pela natureza da solução que se apresentou aos conflitos, interessou-me entender com mais profundidade alguns elementos referente às motivações, conhecimentos e competências, por parte tanto dos técnicos e coordenadores do programa, como por parte dos proprietários atingidos pelo programa, que poderiam colaborar com as crescentes discussões sobre o resgate da qualidade ambiental, atrelada ao resgate da cidadania. Especificamente interessou o modo como se diagnosticou o problema, como se elegeram as áreas prioritárias, como se estruturou o programa a partir das crenças e leituras dos seus idealizadores e a abordagem junto aos proprietários. Por parte dos proprietários interessou conhecer as leituras e olhares dessas pessoas, o que não foi possível no programa do Consórcio que, de início, se fechou às oportunidades de diálogo e participação efetivas. A história local, a história de vida das famílias, sua lógica no uso e ocupação do espaço, sua visão da fauna e flora, suas dificuldades, seus sonhos, além da avaliação do programa, o que puderam fazer agora - ao meu ver - de modo mais crítico e livre, após 7 anos do início do programa.

Por trás dessa insistência na importância da participação efetiva por parte dos proprietários, em programas como o estudado, está a crença na imprescindibilidade da superação do mero enfoque punitivo na conservação e resgate da qualidade ambiental, para ações educacionais que, de forma 
coerente diagnostiquem o problema, prezem pela participação da comunidade (como um fim em si, e como meio para o fortalecimento da população e para a construção do conhecimento), e cobrem a reestruturação e ação das instituições públicas nas áreas que são de sua responsabilidade. Desse modo, acreditamos que a conservação ambiental não será mais um pacote tecnológico empurrado para uma população fragmentada e desorganizada - tal qual na 'revolução verde', contribuindo inclusive para a atual crise ambiental -, mas sim uma ação, que entenda a importância da participação do elemento humano, tanto na destruiçāo como na reconstrução dos espaços que ocupa. 


\section{Metodologia}

- método adotado e sua importancia (para o bom desenvolvimento da pesquisa e também para o crescimento de seu autor) encontram na obra "Métodos de Pesquisa em Ciências Sociais", de Howard Becker, fortes incentivos:

"As situações de pesquisa qualitativa incentivam, poder-se-iam dizer exigem, a improvisaçáo, e muitos pesquisadores qualitativos sentem que suas soluçóes ad hoc para os problemas de campo têm pouco valor fora da situaçăo que as evocou. (...) problemas de método săo sempre relativos à organizaçăo das relaçčes entre pesquisadores e as pessoas às quais estudam (...)" (Becker, 1994: p. 14).

Em resposta à dificuldade quanto aos risco de 'tendéncias incontroladas' nos procedimentos da pesquisa, diz 0 autor:

"Ao invés de insistir em procedimentos mecânicos que minimizam o julgamento humano, podemos tentar tornar as bases destes julgamentos tăo explícitas quanto possivel, de modo que outros possam chegar a suas próprias conclusరes" (Becker, 1994: p. 20).

As opçóes metodológicas nesta pesquisa seguiram também orientaçס̌es gerais que podem ser encontradas na obra de Almeida (1989), "Pesquisa em Extensáo Rural: um manual de metodologia". De grande utilidade foi a leitura de "Notas para o Debate sobre Pesquisa-Açăo", de Michel Thiollent, que contribuiu para a definiçăo de rumos, ao mesmo tempo em que esclareceu as limitaçőes que levaram o presente trabalho a năo ser desenvolvido como pesquisa participante ou pesquisa-açăo: a pouca maturidade para leitura dos conflitos revelados no decorrer da pesquisa, as dificuldades de inserçăo simultânea em ambos os lados confitantes, a compreensăo da lógica do Programa tardiamente, entre outras. Embora entenda que as entrevistas em si 
tenham se configurado como espaço de expressão, provocação, diálogo e reflexão junto a proprietários e técnicos, vale ainda a crítica de Thiollent (1984: p.87):

"A pesquisa acadêmica e suas convencionais técnicas de pesquisa predispõem a uma forma de conhecimento codificado de acordo com regras do mundo universitário sem retorno em direção ao povo. De acordo com esse tipo de crítica, a pesquisa acadêmica é pouco utilizada concretamente, só serve para a obtenção de títulos entre uma pequena minoria privilegiada".

O método desenvolvido para a produção desta dissertação, envolveu a estruturação e planejamento da etapa de campo, a escolha do tema, a busca de referenciais teóricos que pudessem contribuir efetivamente para a compreensão do caminho pretendido pelo autor, a seleção do programa e da região, a tabulação e análise dos dados e as inúmeras conversas, encontros e reuniões que auxiliaram no amadurecimento para a redação deste trabalho.

A escolha do tema 'reflorestamento ciliar' se constituiu uma estratégia de viabilização da pesquisa, em função da necessidade de um mínimo aprofundamento no amplo contexto da conservação ambiental no meio rural. Tal como o reflorestamento ciliar, outros temas favorecem a reflexão do contexto maior sobre as formas de organização sociais e políticas (instituições, técnicos, cientistas, cidadãos urbanos e rurais) no enfrentamento da crescente degradação ambiental: reserva legal, saneamento básico, sistemas de produção agropecuários, planejamento e conservação das vias públicas, comercialização de produtos agrícolas, erosão agrícola e assoreamento dos rios, etc). Interessou mais ao autor, porém, verificar o modo como se relacionavam os proprietários (e principalmente produtores) rurais, com o elemento arbóreo, e principalmente, o modo como a nova estrutura (instalada, porém ainda 'em construção') de gestão dos recursos hídricos (o Consórcio Intermunicipal) estava entendendo sua contribuição e seu modo de ação neste contexto rural. 


\subsection{Aproximação inicial da realidade}

Em busca de informações sobre os acontecimentos do passado (história da microbacia, história do programa) e sobre uma possivel caracterização das propriedades da microbacia, encontrei algumas dificuldades:

- o museu de Capivari em reformas (acervo indisponivel) e sem documentos específicos sobre a microbacia (informação pessoal obtida com um funcionário);

- os laudos oficiais realizados pelo engenheiro a serviço do Consórcio desapareceram no trâmite entre o DEPRN de Campinas, o DEPRN de Piracicaba, a coordenação do Consórcio, e uma funcionária que iniciou o programa, em 91;

- a descrição oficial do programa, pelo Consórcio, era parcial e não revelava a forma de abordagem e comunicação no campo, e os prováveis conflitos que poderiam ter ocorrido no processo.

Desse modo, optei por uma reconstituição dos fatos, principalmente a partir do depoimento dos diferentes atores que participaram do programa, buscando justamente expor as diferenças de concepções e percepções da realidade, ora mais atentos aos fatos em si (o que aconteceu), e ora mais atento às razões que levaram os entrevistados a construirem tais versões tão diferentes dos fatos. Os conflitos algumas vezes descritos e a disparidade de alguns depoimentos nos revelam no mínimo a não comunhão entre coordenação e público-alvo do programa. Aliás, a reflexão sobre quem seria o tal público-alvo de uma experiência desenvolvida nesses moldes, pode nos ajudar a compreender aquilo que a equipe do Consórcio chamou de 'resistência' dos proprietários.

Em alguns momentos, desistimos da pretensão de conhecer 'a verdade' dos fatos, seja porque mais nos importou a leitura dos entrevistados, seja porque a simples desconexão entre as versões já teria se configurado um 
dado importante sobre a qualidade do processo comunicativo que se estabeleceu no Programa.

As análises aqui apresentadas referem-se ao Programa em foco. Não se buscou um estudo mais aprofundado do Consórcio, nem das instituições parceiras. A análise, posteriormente desenvolvida na discussão, não representa necessariamente a qualidade e metodologia dos atuais trabalhos dessas instituições. Pretende-se uma crítica construtiva a um evento concreto que iniciado em 91, prolonga-se na microbacia do Ribeirão Forquilha até hoje. ${ }^{1}$

As entrevistas, principal fonte de informações como já disse, foram realizadas junto aos:

i) proprietários rurais,

ii) técnico de campo do Consórcio,

iii) coordenadores da Seção de Proteção aos Mananciais da Secretaria Executiva do Consórcio,

iv) Promotor de Justiçal Curador do Meio Ambiente de Capivari,

v) equipe do Serviço Autônomo de Água e Esgoto de Capivari.

vi) coordenador geral da secretaria executiva do Consórcio.

Procurando facilitar a citação dos entrevistados, mas também cumprir com os acordos iniciais de sigilo (estabelecidos principalmente com os proprietários rurais, mais temerosos pelas possiveis repercussões de suas falas), são usados nomes fictícios, conservando o gênero e relacionando-os às respectivas instituições (função e nome da instituição) quando assim for o caso.

\footnotetext{
${ }^{1}$ Em referência à fevereiro de 1998.
} 


\subsection{Conhecendo a equipe do Consórcio}

Um contato inicial com o Departamento de Água e Energia Elétrica (DAEE) de Piracicaba, me levou até a Sede Executiva do Consórcio, em Americana. Através do coordenador do Programa Semana da Água (aqui chamado Edison), estabeleceu-se uma comunicação permanente com Sérgio, coordenador do Programa de Proteção aos Mananciais, dentro do qual se desenvolveu (e se desenvolve ainda) o Sub-programa de Reflorestamento Ciliar (denominado nesta pesquisa apenas com o termo 'programa').

Para poder conhecer o programa de reflorestamento ciliar do Consórcio, foi buscado e valorizado o contato com os coordenadores (a partir de janeiro de 1997, principalmente em Americana (SP), sede executiva do Consórcio), quando foi apresentada a primeira proposta (anexo A). Na ocasião, o coordenador geral informou a impossibilidade, apenas, de cooperar com a terceira etapa planejada ('trabalhos em grupos' - ver Anexo D), devido à algumas dificuldades operacionais enfrentadas pela equipe da Secretaria Executiva do Consórcio (principalmente escassez de tempo).

A orientação inicial foi a de conhecer o técnico autônomo (o engenheiro agrônomo Antonio) que esteve envolvido com os plantios desde seu início, em 1991. Foi realizada uma entrevista voltada aos aspectos gerais de sua atuação no programa, sem seguir um roteiro pré-estabelecido.

Como a coordenação inicial do programa fora alterada (saíram Ester e Ronaldo, e ficou Sérgio), e o suposto impacto (colocado por Antonio, na entrevista) ocorrera na atuação daquela coordenação, fomos conhecê-los, numa proposta de entrevista. Tal proposta foi recusada por ambos, sob o argumento de não concordarem em falar de uma instituição da qual não mais faziam parte. Mesmo assim, Ronaldo aceitou uma conversa fora dos moldes de uma entrevista semi-estruturada, como havia sido inicialmente planejada.

A partir daí, a abordagem junto aos proprietários rurais (que até então seria apenas complementar ao entendimento da metodologia 
desenvolvida pela equipe do Consórcio) passou a ser central ao estudo, no sentido em que vinha dela a melhor possibilidade de entender 'como poderia ter sido feito' tal programa, para o contexto específico da microbacia. Além disso, pareceu-nos mais verossímil uma narrativa formada por vários proprietários em diferentes condições (fundiária, de recursos, de escolaridade), comparada com a oficial (segundo Ricardo e Romani,1992, e também pelas entrevistas com os componentes da equipe, aqui desenvolvidas). Com o apoio da documentação (principalmente) fornecida por Antonio, foi então, iniciada a comunicação com os proprietários rurais.

\subsection{A relação com os proprietários no Forquilha (fevereiro de 1998)}

Contactei pessoalmente os entrevistados com o auxílio dos rascunhos do primeiro laudo realizado (o original está desaparecido), mapas fornecidos pela Casa da Agricultura de Capivari, e um cadastro (anexo B) desenvolvido por Antonio, quando agendava um dia para uma conversa voluntária, que duraria em média 1,5 h. Entreguei nesse primeiro contato uma folha contendo uma breve apresentação minha, juntamente com um resumo de meu trabalho e endereço para contatos (anexo $\mathrm{C}$ ).

De acordo com as confirmações foram sendo procurados proprietários com diferentes áreas de propriedade, de modo a ser mais representativo dos diferentes impactos do programa e modos de vida e produção da comunidade local.

$\mathrm{O}$ acordo feito era que eu manteria em sigilo os nomes de todos os entrevistados, citando porém, no caso de desempenharem cargos em instituições envolvidas, sua função e o nome da instituição.

Recusei os convites (de auxílio e acompanhamento a campo) do Antonio e do engenheiro agrônomo da Casa da Agricultura de Capivari, devido aos riscos de comprometimento das entrevistas pelos aparentes conflitos do passado, e também pela importância de desvinculação deste trabalho a 
qualquer instituição local ou que esteve envolvida com o programa, dado o desconhecimento do contexto político local até então.

Expliquei que o modo de contribuição do meu trabalho restringiase a provocar uma reflexão sobre o programa de plantio desenvolvido desde 91, que seria publicado em 98 na forma de estudo científico, e que a leitura de tal trabalho pelos agentes desse programa, para um possivel aperfeiçoamento e correção dos procedimentos até aqui adotados, era minha esperança.

A entrevista foi toda anotada em papel, na frente do entrevistado, de forma aberta, sendo incentivado a perguntar a qualquer momento que desejasse o que estava sendo escrito; a proposta de gravação em fita cassete gerou desconforto em quase todos, provavelmente devido a uma situação constrangedora sofrida por um dos proprietários, criada pela equipe do programa, ainda em seu início (segundo ele) envolvendo o uso de tal aparelho;

Quando foi pedida minha opinião a respeito de assunto interno à entrevista, eu devolvi o pedido para que essa opinião minha ficasse para o final da conversa, para que não influenciasse as respostas. Foi aceito em todos os casos, e ao final eu expus minha visão nas questões perguntadas;

Foram realizadas duas entrevistas piloto, e em seguida o roteiro foi alterado dada a repetição de temas, o excessivo tamanho do roteiro, e a falta de uma seqüência mais fluente das perguntas; no passar a limpo, as 2 entrevistas iniciais foram encaixadas nos moldes da versão final.

As informações consideradas sigilosas ou simplesmente pedidas para que não fossem anotadas foram respeitadas; não foram poucos os casos em que esse pedidos apareceram.

$O$ pedido que alguns faziam de conhecer a opinião dos outros, entrevistados anteriormente (ocorreu mais de uma vez) foi negado, com a justificativa do próprio acordo estabelecido, o que contribuiu positivamente para a tranqüilidade do entrevistado no restante da conversa, como se estivesse me testando em meu próprio acordo. 
As perguntas em branco (nas anotações de campo) significam que não couberam no momento ou já haviam sido respondidas.

$\mathrm{Na}$ transcrição das entrevistas, os trechos entre aspas são frases dos próprios entrevistados, com algumas pequenas possiveis modificações de artigos e/ou conjugações. Entre parênteses, eu tentei facilitar a compreensão das frases dos entrevistados, completando-as conforme o contexto da resposta, naquilo que ele já me tinha dito de alguma maneira. $O$ que não está entre aspas, é o depoimento dos entrevistados que não pude captar com todas suas palavras, traduzido então nas minhas (em $3^{a}$ pessoa, mas na estrutura e palavras - sempre que possivel - do entrevistado).

Só foram visitados, por opção do método desenvolvido, aqueles plantios próximos ao local da entrevista (Cláudio e Mateus), ou à beira da estrada (Raquel e Thaís).

O roteiro foi usado em todas as entrevistas como mapa temático para sondagem dos assuntos mais prioritários, sendo poucas as entrevistas em que a leitura fiel da pergunta foi possível.

$O$ roteiro das entrevistas (Anexo $C$ ) foi elaborado segundo $O$ interesse dos autores em se conhecer (ainda que superficialmente, dadas as limitações desse tipo de fonte) o contexto sócio-histórico-ambiental-econômico da microbacia, a qualidade dos serviços prestados, as dificuldades enfrentadas, motivações. No tocante ao programa desenvolvido, os entrevistados foram provocados a resgatar a história, os fatos que os marcaram no processo, além de descreverem com mais detalhes, elementos da metodologia utilizada pelo Consórcio, modelo de plantio, numa breve avaliação do processo.

Foram realizadas 12 entrevistas (entre os 27 proprietários da microbacia).

Cada entrevistado recebeu por denominação uma letra (de $A$ a K), em campo, que posteriormente foi associada à um nome fictício (assim como para as entrevistas com os técnicos e promotor): Estevão, Joaquim, Carlos, Cláudio (e o tio Roberto), Mateus (e o filho Gustavo), o casal José e Ana, 
Leonardo, Lucas (e o sobrinho Miguel), Thaís, Luís, Raquel (e sua mãe, Maria), e Pedro.

Finalizada a etapa das entrevistas com os proprietários rurais, passou-se então à organização dos itens, ou tabulação. Nesta etapa, as respostas foram agrupadas em categorias de análise:

\section{Caracterização dos proprietários}

Pela história familiar e/ou da propriedade

Pela(s) atividade(s) desenvolvida(s) na propriedade

Pelo grau de importância da cultura da cana para a propriedade

Pelo modo de uso do recurso hídrico na propriedade

Pela situação atual dos plantios

\section{Histórico}

Da microbacia

Dos plantios

\section{Núcleos temáticos}

As dificuldades enfrentadas e avaliações sobre serviços/instituições Aspectos relacionados à adesão ao programa e seus impactos A leitura dos proprietários sobre o ambiente e seu manejo As motivações e sonhos dos proprietários Outros aspectos (piscicultura, críticas e observações)

Uma vez transcritas como um todo, o conteúdo das entrevistas foi analisado, à luz dos referenciais teóricos escolhidos e apresentados no capítulo anterior.

A Caracterização dos proprietários é apresentada no capítulo 3, Resultados e Discussão. Resumidamente apresentados no capítulo 3 estão 
também o Histórico (parte textual) e os Núcleos temáticos (nas Estatísticas sobre a opinião dos entrevistados), ambos detalhados no Anexo A.

\subsection{Os estudos, conversas, reuniões, seminários}

Ao longo do desenvolvimento desta pesquisa, surgiram demandas em várias áreas do conhecimento, que não haviam sido suficientemente trabalhadas na graduação (engenharia agronômica), ou simplesmente não faziam parte do currículo. Mesmo entre as disciplinas oferecidas na pósgraduação, não foi possível um melhor embasamento para tais demandas. ${ }^{2}$ Isso trouxe a necessidade de busca de espaços alternativos, como principal fonte problematizadora para a construção da matriz metodológica. Entre eles, destacaríamos:

- Encontros de Educação Ambiental (EA);

- Relacionamento com colegas e professores, no mestrado; ${ }^{4}$

- Convênio LCF/ESALQ/USP e Fundação Florestal; ${ }^{5}$

- Atividade junto ao DEPRN de Sorocaba; ${ }^{6}$

- Encontro sobre Direito Ambiental; ${ }^{7}$

- Encontro sobre Reflorestamento Ciliar; ${ }^{8}$

- Envolvimento com o Programa Semana da Água, ${ }^{9}$

\footnotetext{
${ }^{2}$ Mesmo porque, surgiram principalmente após o primeiro ano, quando já haviam sido cumpridos os créditos.

${ }^{3}$ XIII Simpósio Nacional, em 96 (Belo Horizonte); IV Fórum, em 97 (Guarapari); I Congresso Litoral Paulista e Mata Atlântica -, em 96 (Santos).

${ }^{4}$ Destaque para o corpo de orientação, grupo de pós-graduandos em EA, e o engenheiro florestal André R. Ferretti.

${ }^{5}$ Entre outras, buscava-se a formação de técnicos capacitados, para o aprimoramento da abordagem junto aos agricultores, "promovendo o aumento da eficácia das atividades de extensão e comunicação florestal desenvolvidas pela FF e IF" (comunicação intema).

${ }^{6}$ Vistorias a campo e elaboração de laudos técnicos, com foco principal sobre áreas de preservação permanente (cumprimento dos compromissos de plantio, com essências nativas).

${ }^{7}$ I Congresso Internacional de Direito Ambiental, em agosto de 1996, Bauru (SP).

${ }^{8}$ I Encontro Sobre Reflorestamento Ciliar, em novembro de 1997, São Paulo (SP).

${ }^{9}$ Participando em alguns eventos relativos ao Treinamento Completo (Teórico, Prático e Aplicativo), Para Capacitação de Coordenadores e Professores Aplicadores do Programa Semana da Água, de março a novembro de 1997.
} 
- Aprendizagem de métodos participativos no programa Universidade Solidária; ${ }^{10}$

- Participação em Grupo de Multirão Agroflorestal; ${ }^{11}$

- Encontros sobre Desenvolvimento Rural. ${ }^{12}$

Fundamentais foram as oportunidades de desenvolvimento de atividades didáticas oferecidas pelos coordenadores das disciplinas Projetos em Educação Ambiental (primeiro semestre de 1997) e Sociologia Rural e a Questão Agrária (maio de 1998), envolvendo alguns dos temas aqui trabalhados, e abrindo-nos ricos espaços de troca e problematização junto aos graduandos.

\subsection{Abordagem com outros atores envolvidos no programa}

Como o programa se desenvolveu na forma de parcerias, coordenadas pelo Consórcio, interessou-nos conhecer tais parceiros, no trabalho desenvolvido em Capivari. Foram eles: CESP, Fundação Florestal, DEPRN, Prefeitura de Capivari e Promotoria Pública. Além desses, envolveramse em outros níveis a Casa da Agricultura de Capivari e a Associação dos Fornecedores de Cana de Capivari.

A CESP estava representada por Ester (que atuava na equipe do Consórcio), cujo depoimento não foi possível, como afirmamos anteriormente.

A avaliação do programa por parte da Fundação Florestal (na pessoa Jonas, responsável direto nessa parceria) foi percebida em dois

\footnotetext{
${ }^{10}$ Janeiro de 1997, município de Candeal (BA).

${ }^{11}$ Com destaque para uma das atividades em Ribeirão Preto, onde desenvolve-se plantios em área de mata ciliar no conceito da agrofloresta (ver Götsch (1995) e Milz (1997) nos apêndices), visando a recuperação da faixa exigida pela legislação, com a retirada de alguns produtos (frutas, principalmente) para uso na fazenda.

${ }_{12}$ IV Seminário dos Agricultores Familiares do Estado de São Paulo, em agosto de 1998; e Simpósio Latinoamericano de Desenvolvimento Rural Sustentável, em setembro de 1998.
} 
momentos: na apresentação que compunha um seminário ${ }^{13}$; e em visita à microbacia do ribeirão Forquilha, numa avaliação com a parceria da Fundação Florestal. $^{14}$

O contato com o DEPRN se deram tanto em Piracicaba como em Campinas, em conversas informais sobre o assunto, quando estávamos em busca dos tais laudos de vistoria, originais.

A necessidade de uma entrevista com o Promotor de Justiça de Capivari (Dr. Marcelo, que desempenha a função de Curador do Meio Ambiente, em Capivari), surgiu em função das entrevistas com os proprietários, que nos provocaram a conhecer melhor o seu modo de pensar e agir. Na Casa da Agricultura de Capivari, tivemos o apoio na forma de relatos da história passada, mapas e um documento que teria grande importância no contexto das ações desenvolvidas pelo programa. ${ }^{15}$

Não desenvolvemos qualquer contato com a Prefeitura, e a comunicação com a Associação se restringiu à entrevista com a sua presidenta e proprietária rural, Raquel. ${ }^{16}$

\footnotetext{
13 "Implantação de florestas e sua interface social: o estado da arte", realizado em 27 e 28 de maio de 1995, pelo Convênio Fundação Florestal/ LCF(ESALQ/USP), no Parque Ecológico Monsenhor Emílio José Salim, Campinas (SP).

${ }^{14}$ Quando também avaliaram o programa Antonio (vistoriador) e Sérgio (do Consórcio). Desenvolvida dentro do convênio com a ESALQ/USP, em 30 de julho de 1997. ${ }^{15}$ São Paulo (1990).

${ }^{16}$ A Polícia Florestal e a Sociedade Brasileira de Direito do Meio Ambiente (SOBRADIMA), descritos por Ricardo e Romani (1992) como parceiros do programa geral, não tiveram ação significativa em Capivari.
} 


\section{Resultados e Discussão}

\subsection{Consideraçð̋es iniciais}

Neste capítulo pretendo apresentar e discutir os resultados da pesquisa de campo e das análises sobre os dados coletados. Inicialmente localizo a região estudada, com algumas características da microbacia ( $A$ microbacia do Ribeiråo Forquilha). Em seguida, trago de forma resumida parte das entrevistas que caracterizam os proprietários rurais, e também algumas avaliações sobre o programa (Entrevistas com os proprietários rurais e Histórico dos plantios). Na terceira parte, desenvolvo análises que integram os referenciais teóricos e as informaçóes coletadas na pesquisa.

As categorias de análise geradas a partir das respostas dos entrevistados estão apresentadas a seguir. Os índices devem facilitar a eventual consulta ao conteúdo das entrevistas (nos Anexos $A$ e $B$ ) ao longo da leitura do capítulo.

\section{(H) Histórico (p. 186)}

\section{Ha) Da propriedade (p. 186)}

Temos uma idéia rápida da história de vida do proprietário e de seu nivel de envolvimento com a realidade local.

Hb) Do local/microbacia (p. 188)

Fala da nível de observação/leitura e capacidade de reflexão dos proprietários sobre o seu ambiente (natural, econômico, social, político) ao longo da história.

Hc) Dos plantios (p. 195)

E a descrição do programa, tal como aconteceu, na versão dos proprietários. 
Por exemplo, Em alguns casos foi "negociado" a faixa de plantio (dentro da área de preservação permanente, onde deveriam existir as matas ciliares), reduzindo-a frente à persistência dos proprietários em relação às dificuldades/ impactos que isso acarretaria. Isso foi pra lista dos benefícios do programa, mas sem qualquer responsabilidade legal, oficial, caso o DEPRN ou Polícia Florestal venham a cobrar a faixa completa no futuro.

\section{(1) Sobre as dificuldades enfrentadas e avaliações sobre serviços/instituições (p. 205)}

Nesse campo os proprietários dão as pistas da dimensão dos seus poderes, descrevendo dificuldades materiais, financeiras, de relacionamentos, mas também criticando as omissões e desserviços das ações institucionais. Além do que, fica explícito o grau de desconhecimento dos proprietários sobre a existência e serviços da maioria delas.

1a) Maiores dificuldades (p. 205)

1b) Principal fonte de renda dos proprietários (p. 209)

1c) Tomadas de decisões (p. 210)

1d) Condições do arrendamento (p. 211)

1e) Avaliação da assistência técnica (p. 211)

1f) Sugestões para melhorar esse serviço (p. 212)

1g) Avaliação das escolas do bairro, infraestrutura de apoio à saúde, alimentação, encontro social (p. 213)

1h) Avaliações institucionais (Universidade, Casa da Agricultura, Cooperativa dos Plantadores de Cana de Capivari, Associação, Consórcio Intermunicipal das Bacias dos Rios Piracicaba e Capivari, DEPRN, CESP, Fundação Florestal, Polícia Florestal, IBAMA, Prefeitura, Instituições de crédito, Sindicato) (p. 214) 


\section{(2) Sobre aspectos relacionados à adesão ao programa e seus} impactos (p. 219)

Tratado como exceção no artigo dos ex-coordenadores do Programa (Ricardo e Romani, 1992), a resistência à adesão espontânea foi, na verdade, regra. Tal resistência, rotulada pelos técnicos de comportamento predatório, busca irracional pelo lucro, comportamento anti-social, mostrou-se fundamentada em aspectos variados (sem uma tendência nas respostas), como o da antipatia com a equipe de técnicos, o do conhecimento popular (fruto da observação e experiência) conflitante com 0 dos técnicos, 0 da dificuldade financeira, o da indignação pela falta de coerência (regional) de tal programa, entre outros. Ressalto a importância do item 2a para a compreensão da lógica dos proprietários sobre as matas ciliares.

2a) Mata ciliar (p. 219)

2b) Adesão espontânea (p. 220)

2c) Manutenção e replantio (p. 224)

2d) Legislação e sua influência na adesão ao programa (p. 226)

2e) Custo total do reflorestamento ao proprietário (p. 227)

2f) Imagem dos proprietários frente à comunidade (p. 228)

\section{(3) A leitura dos proprietários sobre o ambiente e seu manejo (p. 229)}

Em continuidade ao sub-item $2 a$, 0 item 3 expressa 0 conhecimento dos proprietários, desenvolvido ao longo de sua história de vida (da qual faz parte seu modo de transformação do meio - trabalho, produção), que resulta em valores atribuidos aos elementos naturais, dos quais a árvore (e a mata ciliar) é apenas mais um. 
Os sub-ítens 3j, 3k, 3l e 3m, mostram um momento da avaliação do programa, que está completando 7 anos.

3a) Modo de proteção da mata ciliar e verificação prática (p. 229)

3b) Mata nativa e a fauna (p. 231)

3c) Nascentes - histórico da conservação (p. 233)

3d) Água - posse e responsabilidade (p. 233)

3e) Faixa de mata ciliar - posse e responsabilidade (p. 234)

3f) Utilização de árvores em geral (p. 235)

3g) Uso da mata ciliar - sobre a restrição de uso e idéias conservacionistas alternativas (p. 236)

3h) Impacto das atividades locais na vizinhança (p. 239)

3i) Impacto do uso das áreas adjacentes à mata ciliar nos recursos hídricos (p. 239)

3j) Alterações observadas na quantidade e qualidade de água na microbacia, em função do programa (p. 240)

3k) Compreensão do modelo de plantio adotado e interesse (p. 241)

31) Sugestões para reformulação do programa (p. 242)

3m) O modo de pensar e o comportamento após o programa (p. 244)

(4) Sobre as motivações e sonhos dos proprietários (p. 246)

Por que querer saber do sonho dos proprietários? O plantio de árvores requer alguma segurança: seja pela posse da terra ou permanência nela, seja pela perspectiva de se perpetuar para os netos através delas, seja pela estabilidade financeira da família, seja pelo prazer de continuar desenvolvendo a atividade agrícola naquele local, etc. Os sonhos são exercícios de planejamento de nossas vidas. Mesmo se desejarmos apenas que os proprietários plantem árvores no chão (desprezando a dimensão da responsabilidade social a ser resgatada), temos que entender o modo como tais 
árvores estão sendo pensadas/contempladas no seus sonhos, para que tais projetos sejam sustentáveis.

4a) Gosto por outra atividade econômica (p. 246)

4b) Balanço geral sobre a motivação frente à localização da propriedade (p. 247)

4c) Sonho futuro para a propriedade e papel das árvores, animais e água nesse sonho (p. 247)

4d) Relacionamento com vizinhos (p. 248)

(5) Sobre outros aspectos (piscicultura, críticas e observações)

(p. 249)

Esse ítem é uma coletânea de contribuições que não se encaixaram bem nas estruturas anteriores, mas que considero de igual importância no contexto da pesquisa. Os sub-ítens $5 \mathrm{c}$ e 5 e elucidam algumas idéias, que auxiliam na compreensão do comportamento e contribuição da presidente da Associação dos Fornecedores de Cana de Capivari à equipe do Consórcio, desde 92.

5a) Piscicultura na microbacia (p. 249)

5b) Causas das análises em 90 e 92 (anexo) e opiniões gerais (p. 249)

5c) Sobre educação de adultos (p. 250)

5d) 'Causos' ... (p. 251)

5e) Sobre a lavoura de cana (p. 251)

5f) Sobre a melhoria das condições ambientais (p. 253)

$5 g$ ) Cobrança pelo uso da água (p. 253)

5h) Sobre um programa de saúde (p. 253)

5i) Avaliações sobre os proprietários locais (p. 254) 
(E) Entrevistas e comunicações com representantes das instituições (p. 255)

Apresento aqui a visão dos técnicos e autoridades envolvidos, que construíram o operacionalizaram as ações no Forquilha, a partir da iniciativa e coordenação do Consórcio. De algum modo todos aceitaram a forma como foi estruturada a ação, o método do Programa, de acordo com seus interesses pessoais e/ou institucionais, suas concepções de vida, trabalho, comunicação e conservação ambiental. Os niveis de conhecimento, competência e responsabilidade social dessas pessoas estão apresentados de forma superficial, mas suficiente para sua compreensão no contexto do Programa.

\section{Consórcio}

Desenvolvo uma análise institucional do programa do Consórcio mais adiante, para o contexto do programa de reflorestamento ciliar.

Ea) Antonio e Flávio (técnicos de campo, autônomos, antigo e atual) (p. 255)

Eb) Ronaldo e Sérgio (coordenadores do programa, antigo e atual) (p. 257)

Ec) Almir (coordenador geral da secretaria executiva do Consórcio) (p. 263)

Ed) Mário (Prefeito de Valinhos e atual presidente do Consórcio) (p. 270)

Ee) Edison (ex-coordenador do programa Semana da Água do Consórcio) (p. 271)

\section{CESP}

Ef) Ester (funcionária cedida pela empresa para o Consórcio) (p. 271)

Parceira de coordenação do programa de 91 a 96, Ester preferiu não se pronunciar a respeito.

Fundação Florestal

Eg) Jonas (responsável pela parceria com o Consórcio) (p. 271) 
Promotoria de Justiça/ Curadoria do Meio Ambiente de Capivari Eh) Marcelo (p. 272)

Casa da Agricultura-CATI

Ei) Márcio (Capivari) e Otávio (Piracicaba) (p. 277)

\section{SAAE}

Ej) equipe administrativa e técnico de laboratório na ETA (p. 278)

\section{DEPRN}

Ek) Valdir (Piracicaba) e Sônia (Coordenadora Geral da regional de Campinas) (p. 278)

\subsubsection{A microbacia do Ribeirão Forquilha (Capivari, SP)}

A microbacia estudada pertence ao município de Capivari, e faz parte da bacia do Rio Capivari - que abrange os municípios como Louveira, Campinas, Monte Mor, Elias Fausto, Mombuca, Rafard, entre outros (fig. 5).

Pudemos comprovar que a forte presença da cana na região nas ultimas décadas, marcou profundamente o contexto agrícola, econômico, administrativo e cultural, na microbacia (uma análise regional pode ser encontrada em São Paulo (1994)). A segmentação das propriedades, através das partilhas entre os herdeiros (principalmente entre os médio e pequenos), agravou os problemas associados ao padrão de formato das propriedades, 'do cume ao vale' (figs. 6 e 7 ). 

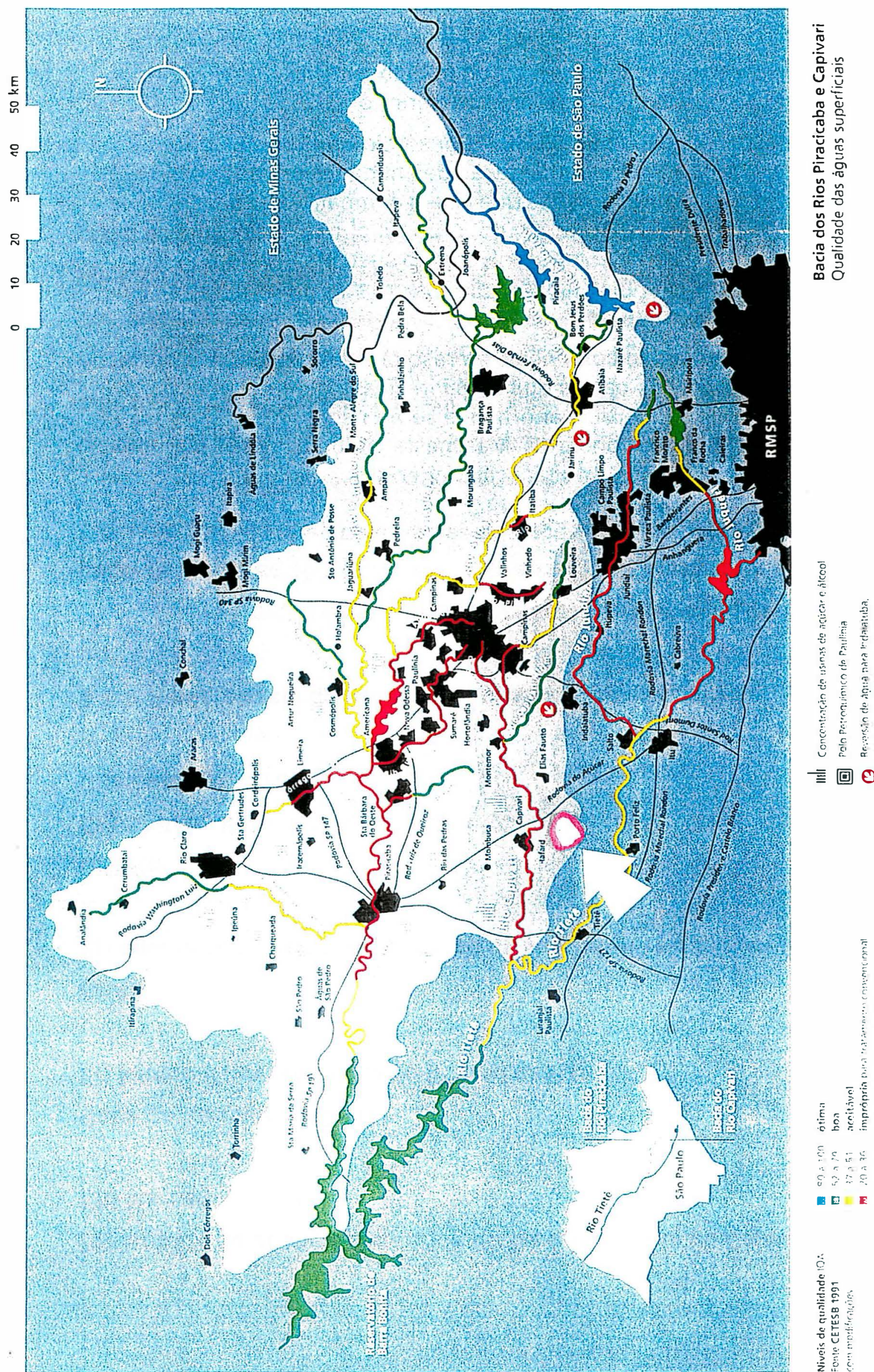

엉

类

응

을 을

ร

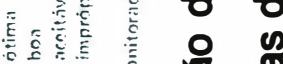

E $=$ ह भु

\&

E $\mathbf{E}$

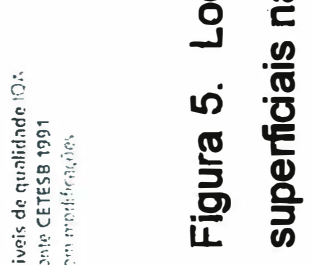




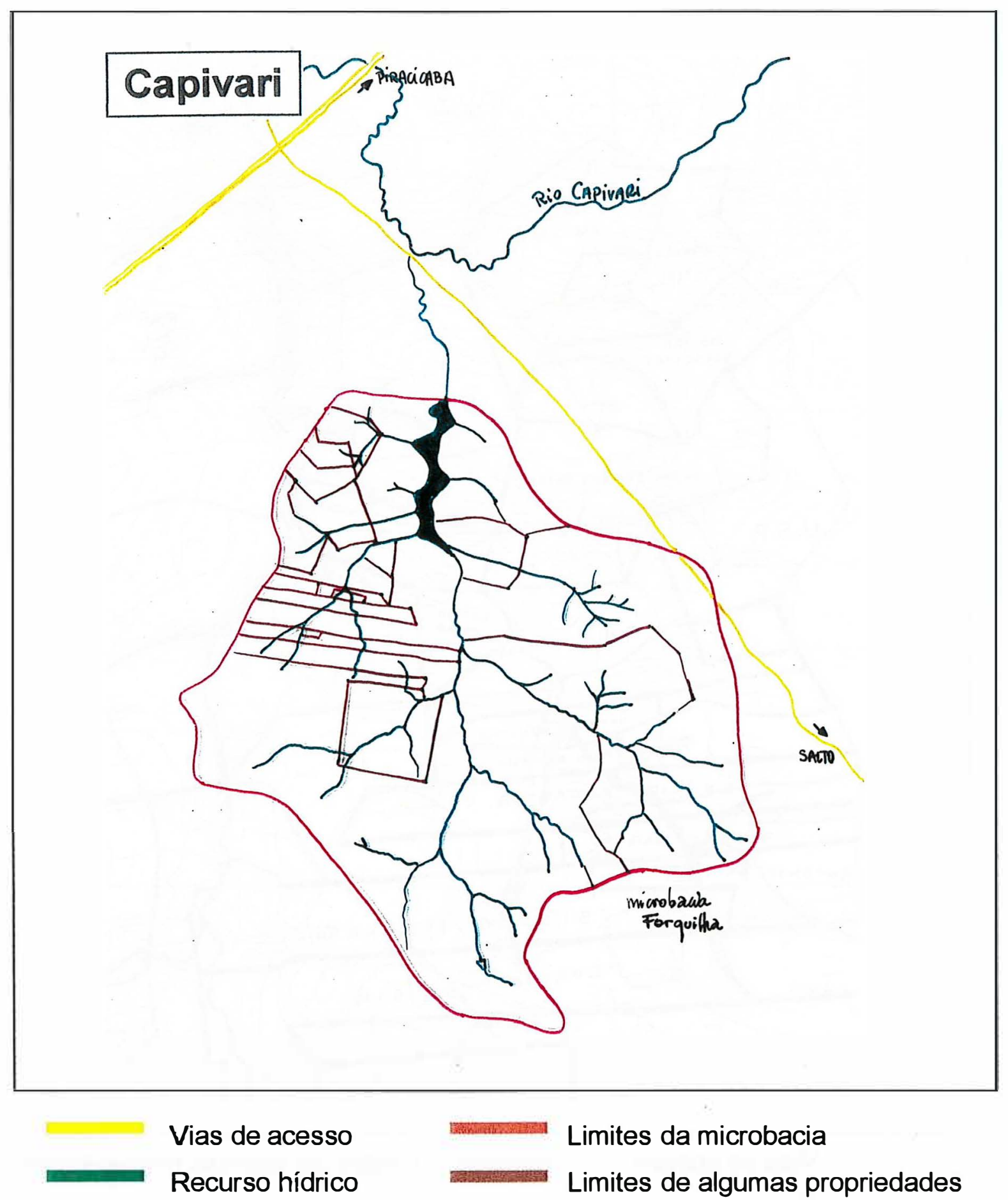

Figura 6. Microbacia do Ribeirão Forquilha, nas proximidades da cidade de Capivari (SP), com destaque para o formato de algumas propriedades (adaptado dos laudos de vistoria do Consórcio). 


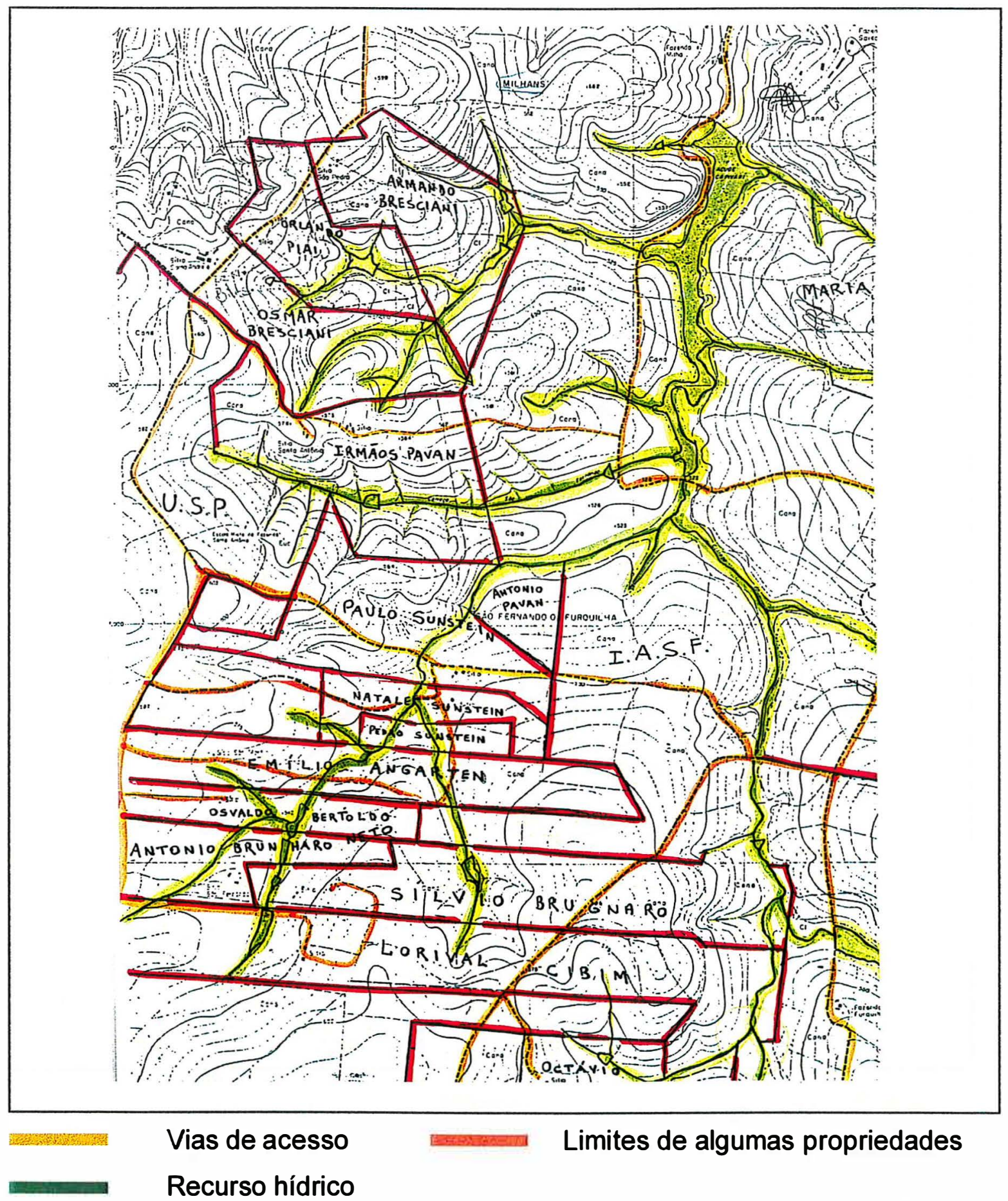

Figura 7. Detalhamento da microbacia do Ribeirão Forquilha, em Capivari (SP): no alto, represa Milhã, em baixo à esquerda o formato de algumas propriedades, no sentido 'cume ao vale' (adaptado dos laudos de vistoria do Consórcio). 
Esta é uma divisão tradicional da terra onde, nos divisores de água são traçadas as estradas, de onde saem os carreadores de acesso às propriedades, geralmente próximas ao recurso hídrico, no vale ${ }^{3}$. Esse desenho possibilita que

toda propriedade seja 'lindeira' do corpo d'água, essencial para o modo de vida e produção de médias e pequenas propriedades. Os carreadores geralmente acompanham a seqüência 'morro-abaixo', facilitando o processo erosivo nas estradas.

A faixa etária predominante na microbacia demonstra a tendência dos jovens buscarem outros meios de vida nas cidades, e revela que para alguns entrevistados, a aposentadoria é uma fonte de renda significativa. A cultura da cana é ainda um fator importante de motivação para a permanência destes na microbacia, considerada ainda (tanto pelas empresárias rurais como pelos proprietários que dependem da força de trabalho da família) como 'dinheiro certo', que permite um planejamento.

As usinas possuem grandes extensões de terra, mas vêm aperfeiçoando significativamente conservação física do solo através, principalmente das técnicas de terraceamento.

O contexto que envolve a represa da microbacia do Ribeirão Forquilha (que responde por aproximadamente $30 \%$ do abastecimento de Capivari) é fundamental para que se entenda a indignação de certos proprietários. Foi construída dentro de um acordo entre a proprietária (Raquel) e a prefeitura, onde a terra não seria doada, mas sim emprestada para a construção da represa. Beneficiaram-se proprietária e prefeitura/população de Capivari; aquela por ter sua terra valorizada, esteticamente, e para a irrigação de suas lavouras (principalmente milho). Atualmente pensa em investir em

\footnotetext{
${ }^{3}$ Tal configuração acarreta uma série de dificuldades para a conservação do solo e da água, e também para a implantação de ações conservacionistas (como o traçado de curvas de nível, que frequentemente deveria extrapolar o limite de cada propriedade). Maiores detalhes podem ser encontrados nos Manuais Técnicos de Manejo e Conservação do Solo e da Água, da CATI (números 38 a 42), de 1994, que compõe o Embasamento Técnico do Programa Estadual de Microbacias Hidrográficas.
} 
ecoturismo, nos entornos da represa. Esta por não ter que indenizar a proprietária e por represar um ribeirão que, apesar dos técnicos do SAEE de Capivari não a terem analisado, teria uma boa qualidade da água ${ }^{4}$, e que vem por gravidade até a estação de tratamento de água (ETA l), em Capivari.

A partir daí, Forquilha que até então não se diferenciava das outras microbacias vizinhas, passou a ser alvo da atenção dos técnicos da casa da agricultura, do promotor, e mais recentemente, do Consórcio. A preocupação é preservar a qualidade deste recurso hídrico. Porém, segundo afirmam os técnicos do SAAE, $0 \%$ do esgoto de Capivari é tratado, sendo praticamente despejado in natura no rio Capivari, que por sua vez, já trazia os esgotos de Campinas, Monte Mor, Valinhos e Vinhedo. Percebe-se portanto que a estratégia adotada está baseada em 2 pontos básicos: o reflorestamento ciliar é a principal medida a ser tomada, inicialmente, e deve ser dirigida às microbacias referentes aos reservatórios de abastecimento urbano, ainda passíveis de serem 'protegidas' a custos muito baixos (comparativamente aos custos do tratamento que seria necessário para que pudéssemos beber a água do rio Capivari, por exemplo). Ou seja. A industrialização mal planejada da região de Campinas e Piracicaba, somada à irresponsabilidade das prefeituras municipais da maior parte dos centros urbanos que aí se encontram (pela estimativa da equipe do Consórcio, aproximadamente $2 \%$ de todo o esgoto é tratado na bacia dos rios Piracicaba e Capivari), levou as administrações a buscarem no represamento dos rios e ribeirões tributários do rio Piracicaba e rio Capivari- comumente localizadas na zona rural -, sua fonte de água para abastecimento urbano.

Essas informações, alguns dos entrevistados mais indignados mostraram conhecer, justificando seu comportamento 'resistente' no programa. Para esses, não faz sentido, em termos ambientais uma ação institucional (assim ela é vista) voltada para coibir atividades de baixo poder poluidor, resguardando o recurso local dos potenciais fatores de degradação, frente ao

\footnotetext{
${ }^{4}$ Segundo eles, tratada de modo convencional: cloração e produtos para desantação.
} 
descaso com as principais fontes de poluição que degradam o rio Capivari. É essa visão estratégica do Consórcio, do seu modo de atuação na realidade regional, que não é aceita por alguns proprietários entrevistados, contribuindo assim para a chamada 'resistência dos proprietários' ao programa. Esse perfil, revela a capacidade de leitura, compreensão e crítica destes, sobre sua realidade - um dos aspectos mais valorizados numa abordagem educativa sobre o contexto ambiental. Obviamente tal qualidade não poderia ter sido valorizada, do modo como o programa foi idealizado e implantado.

Outro aspecto muito importante a ser resgatado em um processo que se deseja educativo, é a dimensão histórica do lugar onde as pessoas vivem, e sua própria história de vida. Se a ação do homem sobre seu meio é cultura, e se a sensibilização/ conscientização das pessoas não se dá fora de seu contexto cultural, então o relato da história pelos entrevistados é mais do que informações sobre a dinâmica de transformação do espaço bio-físico ao longo do tempo: é o resgate da memória das ações concretas das famílias transformando os espaços onde vivem, e explicando o "o que" e o "porque" das coisas, hoje. Abrir espaço para esse relato é reconhecer a importância da cultura (ação do homem no meio) como força propulsora das mudanças que ainda se fazem necessárias à conservação do ambiente, a serem realizadas pelos próprios proprietários. Não abrir tal espaço pode significar a negação da capacidade da comunidade local de gerir de modo racional seu ambiente, inclusive conservando o recurso hídrico. Mais que isso, pode expor a ingenuidade (na melhor alternativa) ou opção (na pior) da equipe do programa, na análise reducionista do problema ambiental, onde não existem determinantes históricos gerados nas interrelações da propriedade agrícola com seu entorno, com a agroindústria, com o mercado, com as políticas governamentais, com a qualidade da assistência técnica institucional que recebem. Assim, tal programa parece-nos caminhar sistematicamente fora dos caminhos que poderiam conduzir o processo para uma solução efetiva, 
integrada, e coerente em vários aspectos (culturais, econômicos, históricos, sociais, científicos).

Levando-se em conta o contexto do município de Capivari, onde até o momento (1998):

- todo seu esgoto é lançado in natura ( $0 \%$ de tratamento) no rio Capivari (segundo os técnicos do SAAE/Capivari entrevistados);

- toda a água captada na microbacia do Ribeirão Forquilha entre as 24 h e 5 h, é diretamente jogada no rio Capivari por incapacidade de armazenamento;

- a água vinda de tal microbacia possui (desde seu represamento na década de 80 , ainda segundo os técnicos) qualidade satisfatória, enquadrada na categoria de tratamento convencional,

busco compreender a prioridade de ação, nesse município, voltada ao reflorestamento ciliar, em detrimento de outras necessidades aparentemente mais urgentes.

Quanto ao tratamento de esgotos em Capivari, um convênio entre o Consórcio e o DAAE teria beneficiado o município com um Plano Diretor de Esgotos, além de um projeto executivo de ETE (estação de tratamento de esgoto), entregue ao prefeito, visando atender uma população de dois conjuntos habitacionais, num total de 1.250 residências. Ambos foram elaborados em 1991 (Monticelli \& Barros, 1992). Entrevistas indicam que os projetos não foram concretizados.

Ainda buscando os argumentos para a existência de um Programa de Reflorestamento Ciliar, nesse início de atividades do Consórcio, encontro no capítulo 3, Propostas para Reverter a Situação Atual, o seguinte trecho:

"A reversão da situação atual e da perspectiva de degradação ambiental é possivel, através de diversas atividades e investimentos nas Bacias do Piracicaba e Capivari. Num primeiro momento é preciso evitar a degradação 
dos nossos mananciais. A médio e longo prazo é preciso recuperar a totalidade de nossos rios" (Monticelli \& Barros, 1991).

É oportuna a citação da obra de Caubet \& Frank (1993):

"(...) fica sempre mais evidente que as organizações, que apoiam financeiramente projetos ambientais, querem ver resultados concretos em pouco tempo. Por esta razão são privilegiadas ações pontuais, que dão o devido retorno ao investidor, mas se diluem infinitamente no balanço geral dos problemas ambientais.(...) sem sombra de dúvida, não se atingirá uma situação de sustentabilidade ecológica com ações pontuais e cosméticas. As modificações estruturais são fundamentais (...)" (Caubet \& Frank, 1993: p.6).

Para os autores, é de fundamental importância a forma de ocupação humana do território:

"A ocupação concreta do espaço não é apenas a expressão do confronto ativo das sociedades humanas com seu ambiente espacial, mas também uma resultante da organização social e das dimensões culturais. O uso do solo se torna assim o ponto de ligação decisivo entre processos sociais e naturais, por ser o elo que conecta procedimentos nos sistemas sócioeconômico e natural" (Caubet e Frank, 1993: p.14).

Com base nas informações levantadas em Capivari, a proteção aos Mananciais através dos reflorestamentos ciliares, se justificaria apenas em função de continuar garantindo a boa qualidade da água na microbacia do ribeirão Forquilha, e não de seu resgate. Isso significa maior atenção às ações preventivas (visando minimizar a desestruturação do solo e o transporte de sedimentos para os corpos d'água, minimizando assim a erosão e o assoreamento destes), e menor atenção ao combate de fontes poluidoras (pontuais ou difusas). Qualquer uma delas, carece, porém, de análises dos solos, da qualidade da água, da taxa de assoreamento dos riachos, ribeirão e 
represa, para a tomada de decisões. Não existiram iniciativas do Programa nesse sentido.

Porém, um documento elaborado pela CATI possivelmente tenha influenciado a opção do Consórcio. Trata-se do Plano de Manejo da Bacia Hidrográfica do Forquilha (São Paulo, 1990), sobre o qual não encontrei junto às equipes das atuais CATI/Capivari e CATI/Piracicaba, citação do método de coleta de dados e nem os dados propriamente ditos (seu detalhamento já foi apresentado no capítulo 1).

Com base nos laudos que o técnico de campo do Consórcio nos forneceu, podemos ter uma visão geral do desempenho dos plantios, na microbacia do Ribeirão Forquilha:

Projeto inicial: $\quad 120.004$ mudas

$1^{\mathrm{a}}$ fase

Plantios: $\quad 96.831$ mudas

Replantios: $\quad 11.995$ mudas $(12,4 \%$ de mortalidade)

$2^{\mathrm{a}}$ fase

Plantios:

17.848 mudas

Replantios: 11.170 mudas (não foi possível o cálculo exato do que representa esse replantio em termos de mortalidade)

Total plantado: 114.679 mudas

Total replantado: 23.165 mudas (idem replantios da $2^{\mathrm{a}}$ fase)

Obs.: existiram áreas onde houve a regeneração natural da mata, equivalentes a economia de 7.925 mudas (estimamos uma média ente os espaçamentos $3 \times 2$ e $3 \times 3$, para a conversão em hectares, e chegamos a aproximadamente 6 ha onde houve essa regeneração). Assim considerado, 0 programa teria coberto uma área equivalente ao plantio de 122.604 mudas (73,5 ha, aproximadamente) 
Até maio de 1994, o Consórcio já tinha conseguido reflorestar 53,26 ha dos 74,42 planejados (Barros e Monticelli, 1995). O gráfico a seguir (extraído do relatório do resumo das atividades do Consórcio entre 1989 e 1996), ilustra o desempenho geral do Programa de Reflorestamento Ciliar (fig. 8), e indica ser este o próprio Programa de Proteção aos Mananciais.

\section{Programa de Proteção aos Mananciais}

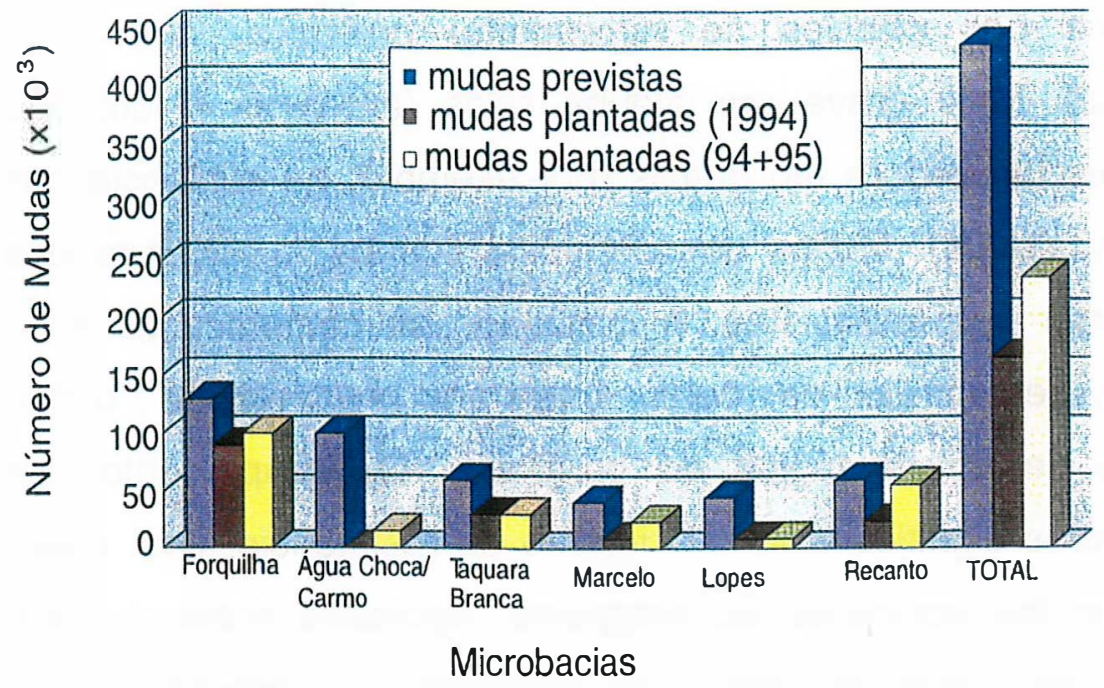

Figura 8. Desempenho geral do Programa e específico para a microbacia do Ribeirão Forquilha (extraído de Consórcio, 1998). Obs.: O título acima compõe a figura original.

Assim, concluo que o reflorestamento ciliar, nos moldes do programa aqui estudado, se justificaria pela:

1) reivindicação histórica dos movimentos que antecederam a criação do Consórcio;

2) crença na estratégia de, começar as ações, resguardando a qualidade e a quantidade de água dos atuais mananciais. Inseparável desta, é a crença de que o reflorestamento ciliar não só é uma etapa importante, como deve ser a primeira, visando a proteção dos mananciais; 
3) inspiração no modelo de programa desenvolvido em Maringá (PR)

4) conveniência das parcerias relativamente facilitadas, que propiciavam 0 poder legal de intimidação dos proprietários, as estruturas mínimas para a ação, e os insumos necessários;

5) vantagem de se optar por uma ação de custos baixos, relativa rapidez de obtenção dos resultados (árvores plantadas) e boa visibilidade na comunidade local e regional.

A história dos plantios se apresentou polêmica, diante da descrição oficial inicial. Mais grave em alguns fatos (ameaças a um dos entrevistados), mais esclarecedora em outros (por exemplo, na eficiência das reuniões com os agricultores). Muitos dos aspectos ligados à estrutura dos trabalhos foi confirmada nas entrevistas. A qualidade da comunicação ficou evidente, confirmando seu caráter de "comunicado aos proprietários", o que também foi coerente dentro da lógica do programa. O agrupamento dos proprietários em reuniões significava fortalecimento da resistência, com maior riqueza de argumentações contrárias ao programa, apoiados entre si. Já o tratamento individualizado (que se seguiu às reuniōes), na assinatura dos termos de compromisso - entre a equipe e o proprietário, em sua própria terra, ou deste junto ao promotor, em uma convocação oficial - significava a facilidade no estabelecimento dos 'acordos'. Nesse momento, foi indispensável para o ambiente de coerção a criação do fato legal (realizada por meio da vistoria), que juridicamente colocava os proprietários nas mãos da equipe do Consórcio, via promotor de justiça. A partir daí, já não haviam formas de comunicação ou mesmo manifestação: sindicato não atuante, associação (cuja presidenta é a Raquel) dos fornecedores de cana colaborando com a equipe do programa, o advogado da cooperativa dos fornecedores de cana alheio ao processo e orientando no sentido favorável ao programa, a justiça institucionalizada contra eles. Talvez seja esse o ponto mais vulnerável de um programa pioneiro que se assume como tal e necessita de 'feed-backs' para seu aperfeiçoamento. Se as

\footnotetext{
${ }^{1}$ ver Naldony e Contar (1990)
} 
espécies escolhidas não tinham bom desempenho ou morriam em determinada área, a vistoria encarava como falta de manutenção do proprietário, o que acarretava multa a ser transformada em área adicional de plantios. Não se discutiu a adequação das espécies escolhidas para aquele ambiente, nem tão pouco sua adaptabilidade ao ambiente (brejos, geadas, herbivoria, competição com gramíneas). Prático, operacionalmente, mas incoerente com um programa pioneiro; péssimo para o desenvolvimento da tecnologia de revegetação para a região.

Para compensar a falta de interlocutor e de informações, alguns proprietários contrataram advogados por conta própria, comprometendo porção significativa de sua renda, e mesmo assim não se livrando do esquema legal encontrado pelo programa. Nesse sentido, realmente se saíram melhor os que aceitaram o programa logo no início e investiram algum recurso (dinheiro, tempo, mão-de-obra) na manutenção, escapando das taxas cobradas pelo fórum para cada convocação, das multas transformadas em áreas adicionais de plantio, dos desgastes com a equipe do programa, das idas e vindas até o fórum de Capivari, dos custos da contratação de advogados.

\subsection{Entrevistas com os proprietários rurais}

\subsubsection{Caracterização dos proprietários rurais entrevistados}

\section{História familiar e/ou da propriedade}

Entre os 12 proprietários rurais entrevistados, a média aproximada das idades foi estimada em 50 anos. A maioria deles (10) nasceu e cresceu na microbacia - a família adquiriu a propriedade no século passado (4), na década de 30 (2), na década de 40 (3), ou na década de 60 (1). Dos outros dois (não nascidos na região), um veio na década de 60 , e o outro é funcionário (desde 82) da Usina, instalada na região na década de 40. 
A maioria das famílias descende de italianos, suíços ou alemães.

Atividade(s) desenvolvida(s) na propriedade

A microbacia do Ribeirão Forquilha é essencialmente canavieira, mas existe também área significativa de pastagens e outras lavouras. Todos os entrevistados são fornecedores de cana. A usina (IASF) trabalha exclusivamente com cana; para as duas grandes proprietárias, a cana é tão importante quanto o milho (verde e seco) ou a empresa de transferência de embriões (em cada caso); os médios, trabalham com pequenos rebanhos bovinos, mantendo parte significativa da área com pastagens ou capineiras. Os pequenos dizem ter na cana a segurança do 'dinheiro certo' (mesmo com a recente liberação do seu preço, para livre negociação com a usina), e ocupam a maior parte da propriedade com essa cultura. Sua criação para 'consumo/uso' (não comercializada) - gado de leite, galinha, burro - e alguma pequena criação também comercializável - porco, bezerros - ficam geralmente concentrados na área de preservação permanente (APP), pela maior facilidade no acesso à água ou melhor desenvolvimento do capim.

\section{Tamanho das propriedades}

As entrevistas englobaram grandes, médios e pequenos proprietários (veja a fig. 7), desde mão-de-obra exclusivamente familiar (José e Ana), passando por 6 empregados assalariados - entre permanentes e sazonais - (Lucas), até empresa sucro-alcooleira (IASF).

Importância da cultura da cana para a propriedade

Para os pequenos e médios, a renda proveniente da cultura da cana ainda representa a segurança financeira, garantia de 
permanência/existência da propriedade. As outras atividades econômicas elou de subsistência complementam as necessidades em renda e/ou alimentação, respectivamente, nem por isso menos importantes para a estabilidade e qualidade de vida dos proprietários.

As variações climáticas (chuvas principalmente) e de mercado (preços), levaram à consagração da cana como principal atividade econômica da microbacia e da região, tanto para pequenos, como para médios e grandes, embora em diferentes contextos. Alguns definem a cultura como: de 'pouco lucro e baixo risco' (Mateus); 'não é muito rendosa, mas sabe quanto vai receber' (Thais);

\section{Modo de uso do recurso hídrico na propriedade}

Com exceção da usina (IASF), todos os entrevistados disseram usar a água da propriedade. Percebeu-se que este recurso é tanto mais importante quanto mais tempo o proprietário passa na propriedade, ou mais ainda, se ele mora nela. $O$ uso da água poderia ser dividido em: irrigação, tanque de piscicultura, criação animal, higiene de estruturas de criação, higiene das moradias (proprietários e empregados), e bebida e/ou alimentação dos moradores/trabalhadores.

A água do ribeirão é na maioria das vezes usada diretamente nos tanques, para irrigação, higiene e alimentação da criação. Não é bebida. A água que se bebe, ou vem das minas (nascentes), canalizada e sem tratamento, ou vem de poços artesianos ou semi-artesianos, de acordo com as possibilidades financeiras do proprietário.

Através do histórico narrado pelos entrevistados, verificamos o forte envolvimento de alguns com o meio em que vivem, uma vez que a microbacia vem se constituindo sua própria casa, literalmente. As descrições da fauna e flora evidenciam o processo de transformação que ocorreu por lá, intimamente ligado aos ciclos econômicos e seus incentivos governamentais. 
Não encontramos percepções negativas sobre as árvores na propriedade; apenas que, no contexto produtivo (independente do tamanho da propriedade), elas competem pelo uso do espaço, associado à renda. Isso leva os entrevistados a pensarem primeiramente em 'lugares adequados' para o plantio das árvores, e depois na utilidade das árvores em si (sombra, atração de pássaros, frutas, conservação do solo). Assim, o impacto dos plantios foram tanto maiores, quanto mais ocupada e planejada para a produção estava a faixa de mata ciliar; seja para a produção de culturas comerciais, seja para subsistência. Esta última, situação típica das propriedades familiares e de pequena área, onde as terras mais altas e contínuas estão com cana, e a faixa mais úmida ao longo de todo o ano (à beira do ribeirão) está ocupada com a produção de subsistência ou de menor renda (gado leiteiro e capim, galinhas, porcos, milho, arroz, etc).

\subsubsection{Histórico do programa e contexto local}

\section{Situação atual em relação aos plantios}

Com base no levantamento feito pelo técnico de campo do Consórcio, foram construídos dois gráficos: um referente às áreas das propriedades (fig. 9) e outro que expressa a porcentagem, da área, com fragmentos de vegetação (florestas, capoeiras, pastos sujos), que já existiam na propriedade (levantamento aproximado à época das vistorias), e a porcentagem da área que o projeto iria ocupar, com os plantios de árvores na faixa ciliar (fig. 10). O asterisco indica que apenas uma parte da propriedade se encontra na microbacia do Ribeirão Forquilha.

A partir das informações também recolhidas junto a este técnico de campo, foi possível a correlação entre a área das propriedades e sua situação (ou comportamento, impactos) frente ao programa (tabelas 2 e 3 ).

Entre os 5 que não implantaram totalmente, as causas variam. 
Figura 9. Área das propriedades na microbacia do ribeirăo Forquilha, em Capivari, SP

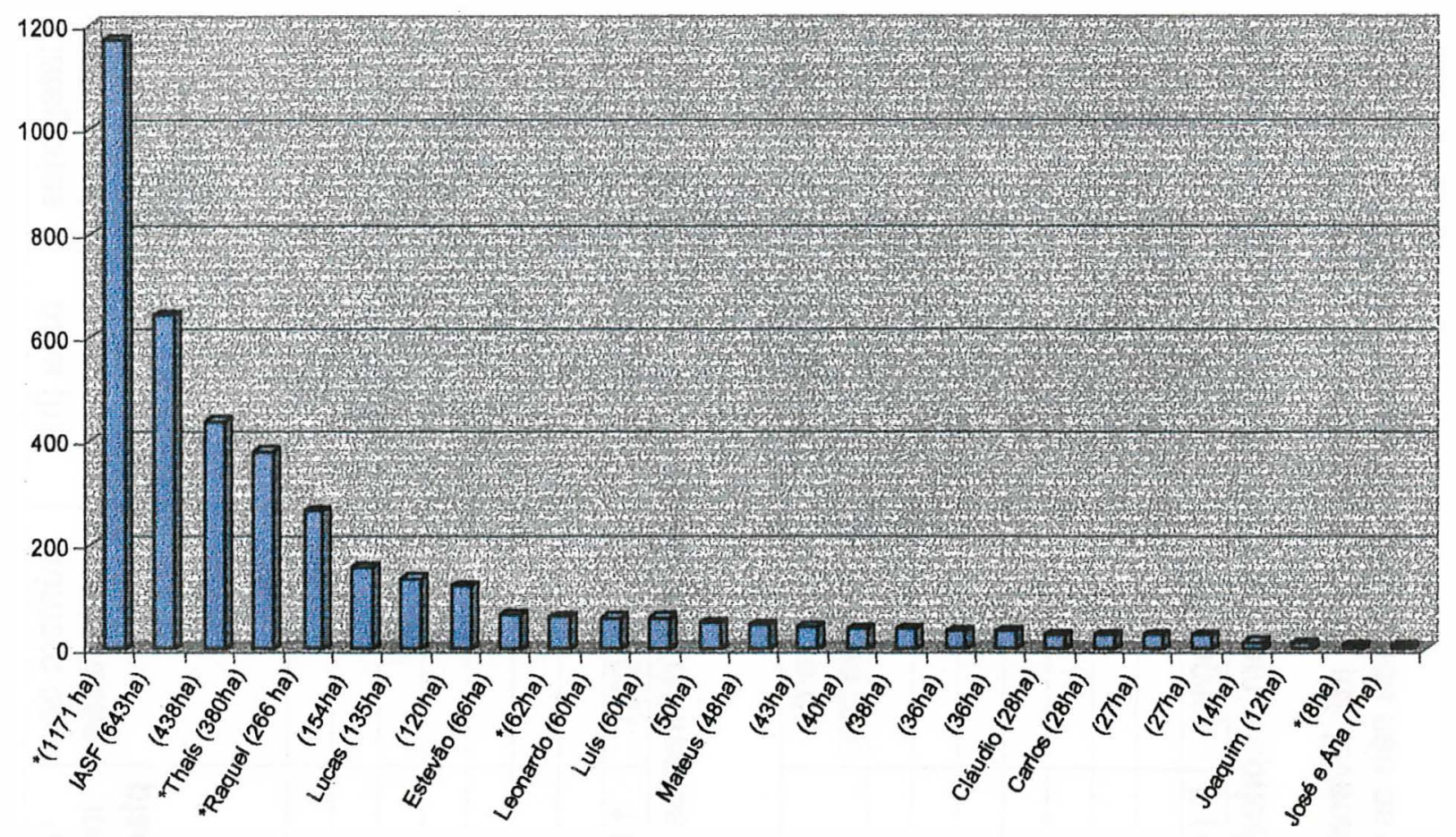

Figura 10. Participaçäo (em \%) dos fragmentos vegetais e das matas ciliares na área das propriecades da microbacia do ribeirão Forquilha em Capivari, SP

Q\% de mata cilia inplotado D\% de fragna tos vegetas já eostertes

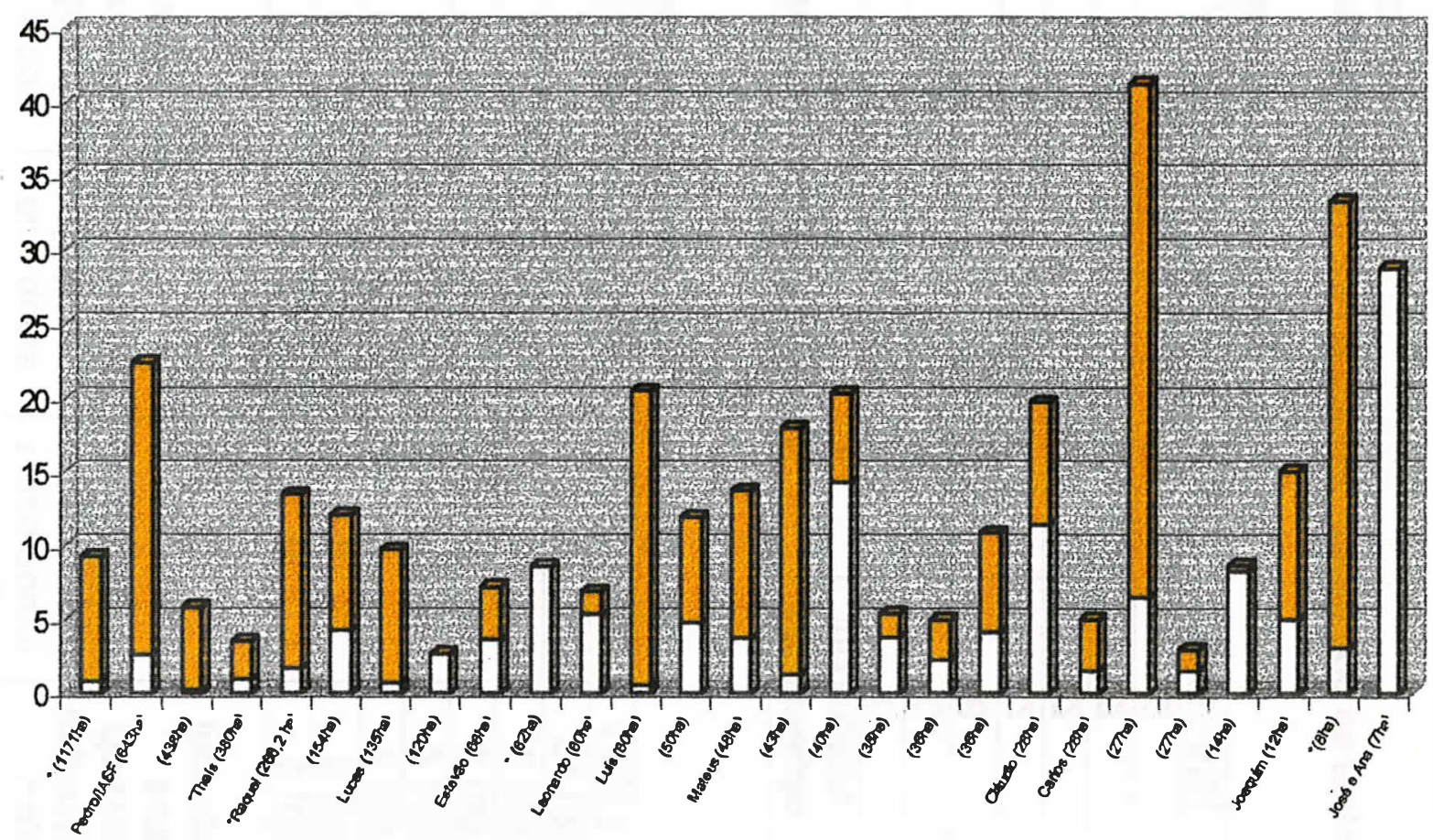

Proprietálios (e árę da proprtedede) 
뭉

\% के

(1) $\rightarrow$ 웅

$\rightarrow \equiv$

응

응 응 흘

ส.

궁

जิ

$\rightarrow$

웅

‥

으

을

จุ

8

สำ

ㄴ.

3

उे

흥

吾

흥응

음

空

氶

离

을

똥

$\overline{3}$

유을

\&

\&

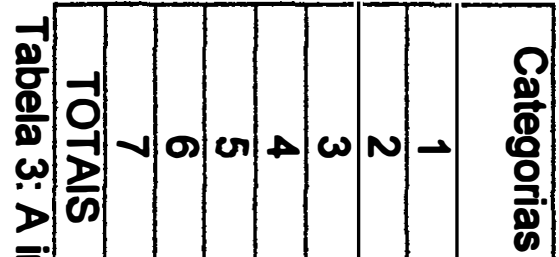

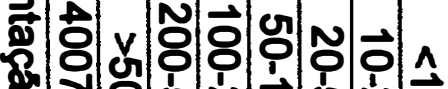

- 8 빙영 싱

응 잉ㅇㅇ응

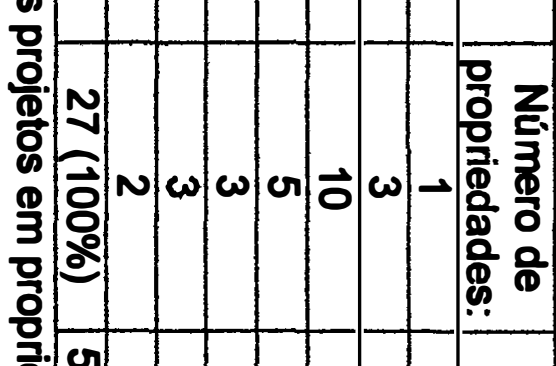

\$.

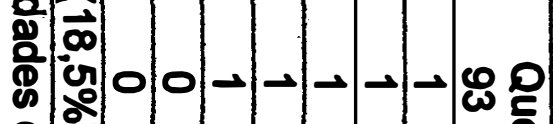

을

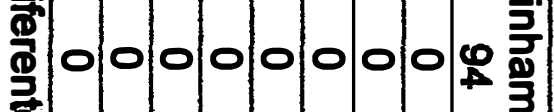

罳会O-O-NNO\&

吾

ర大e

: $0000000 \%$

:

(I)

胥

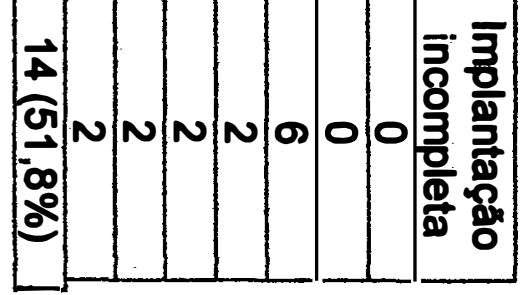

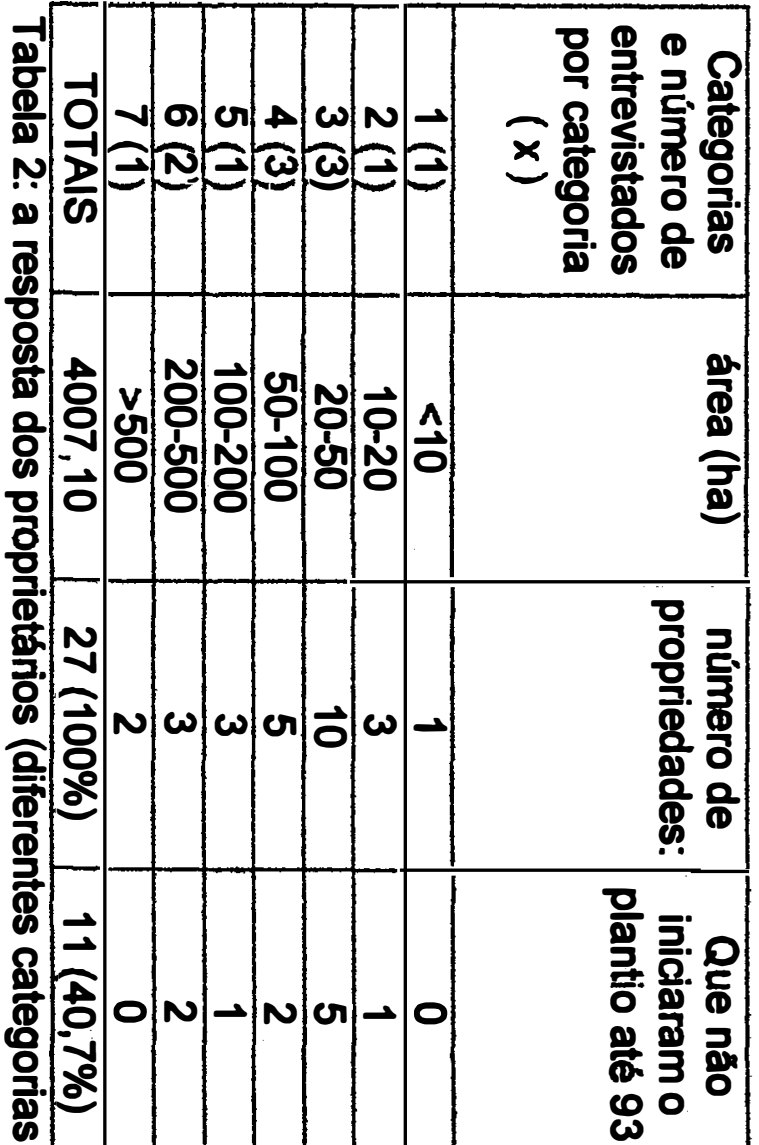

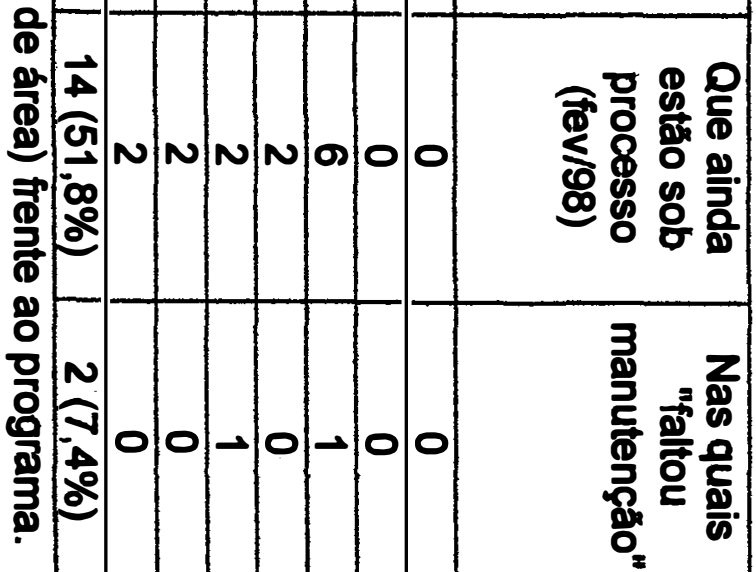

cr

$\vec{\infty}$

हू

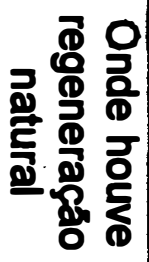

A N N N NOOO

जิ

क 영영영 
Estevão diz que implantou tudo como o combinado, reclamando da desinformação. Tentando explicar as possíveis razões, cita um levantamento fotográfico que o técnico deveria fazer em sua área, no valor de R\$1200 e que ele teria se recusado a aceitar. Ou talvez por causa de seus tanques (de piscicultura), sem cobertura florestal em volta.

Cláudio explica que teve problemas em área de brejo (sazonalmente alagada, ocasionando a mortalidade das mudas), com o capim braquiária (que "não deixa a muda vir") e a saúva cortando as mudas (segundo o proprietário, existe muita burocracia para a aquisição das iscas, e "se o fiscal pega [sem a devida permissão], processa"). Outro motivo para ele estar sendo processado teria sido o rompimento de um acordo verbal por parte da equipe do programa, feito no início, garantindo que ele poderia deixar uma faixa de capim beirando seu tanque, pra caminho do gado. Depois a equipe mudou de idéia ao longo das vistorias e, hoje é exigido o plantio nessa faixa. Explica que primeiro tudo foi feito (os plantios) conforme o combinado. Daí sobrou muda e ele levou pra outro sítio, pra ser plantada lá.

Thaís, embora esteja na categoria de grande proprietária $(343,7$ ha) e administre uma empresa de transferência de embriōes, justifica-se pela sua má situação econômica deste ano, que teria atrapalhado seus planos de implantação do projeto.

Raquel não foi perguntada a respeito. Segundo o levantamento técnico, falta certa porção de sua área a ser revegetada.

Pedro, funcionário da IASF, não soube informar. Diz que o plantio foi completo, com replantio entre 10 e $20 \%$. Pelo levantamento do técnico, existe a necessidade de completar os plantios e de replantar certas áreas. 
Entre os que implantaram os projetos, apenas Carlos e Joaquim (irmãos e vizinhos), não ofereceram resistência ao programa, embora também fizessem ressalvas ao modo como os trabalhos se desenvolveram. Raquel, mais que aderir espontaneamente, é vista por Antonio (vistoriador, contratado pelo Consórcio) como "liderança natural" entre os proprietários que, segundo ele, contribuiu para a otimização do programa, no Forquilha. Com os demais, a coerção (por ameaças de processo judicial) foi o motivo do eventual sucesso.

As três maiores propriedades (IASF, Raquel e Thaís) cujos proprietários foram entrevistados estão sob processo, para completarem os plantios. Reclamam um pouco dessa situação mas não se mostram indignados. Estariam cumprindo seus compromissos, mas devido ao tamanho da área envolvida, têm Ihes escapado a execução mais obediente aos prazos.

As três menores (José e Ana, Joaquim e Carlos) implantaram os projetos até 1995. Mostram-se favoráveis à idéia de plantar árvores, de conservar a natureza, mas teriam algumas ressalvas quanto ao modo como os trabalhos se desenvolveram. Mesmo José e Ana, que perderam mais terra (percentualmente) e avaliam os impactos do programa como negativos, não se mostraram atualmente indignados com o Programa, assim como Joaquim e Carlos.

Entre as outras seis propriedades, a coerção teve efeitos distintos em face das diferentes posturas dos proprietários, poder aquisitivo ou facilidade de cumprimento dos termos do Programa. 


\subsubsection{Estatísticas sobre as opiniōes dos entrevistados ${ }^{1}$}

Apresento a seguir, algumas tabulações referentes às informações coletadas nas entrevistas. Para facilitar a leitura de alguns dos resultados das entrevistas com os proprietários, criei alguns modelos de tabela. De modo geral, estas apresentam um sub-tema específico (indexado tal qual é apresentado no Anexo A), que pode abranger um ou mais itens; os dados numéricos referem-se ao número de respostas ora afirmativas $(s)$, ora negativas $(n)$. Somadas $(s+n)$ - na linha inferior à esquerda dos quadros -, mostram o número total de entrevistas em cada sub-tema ou item, como mostra o modelo abaixo:

\begin{tabular}{|l|l|}
\hline SUB-TEMA (indice correspondente) & Item \\
\hline Entrevistados: $(\mathbf{s}+\mathbf{n})$ & $\operatorname{Sim}(\mathbf{s}) \times$ Não (n) \\
\hline
\end{tabular}

\footnotetext{
${ }^{1}$ Extraídas de Histórico dos plantios e de Núcleos temáticos das entrevistas, apresentadas no Anexo A.
} 


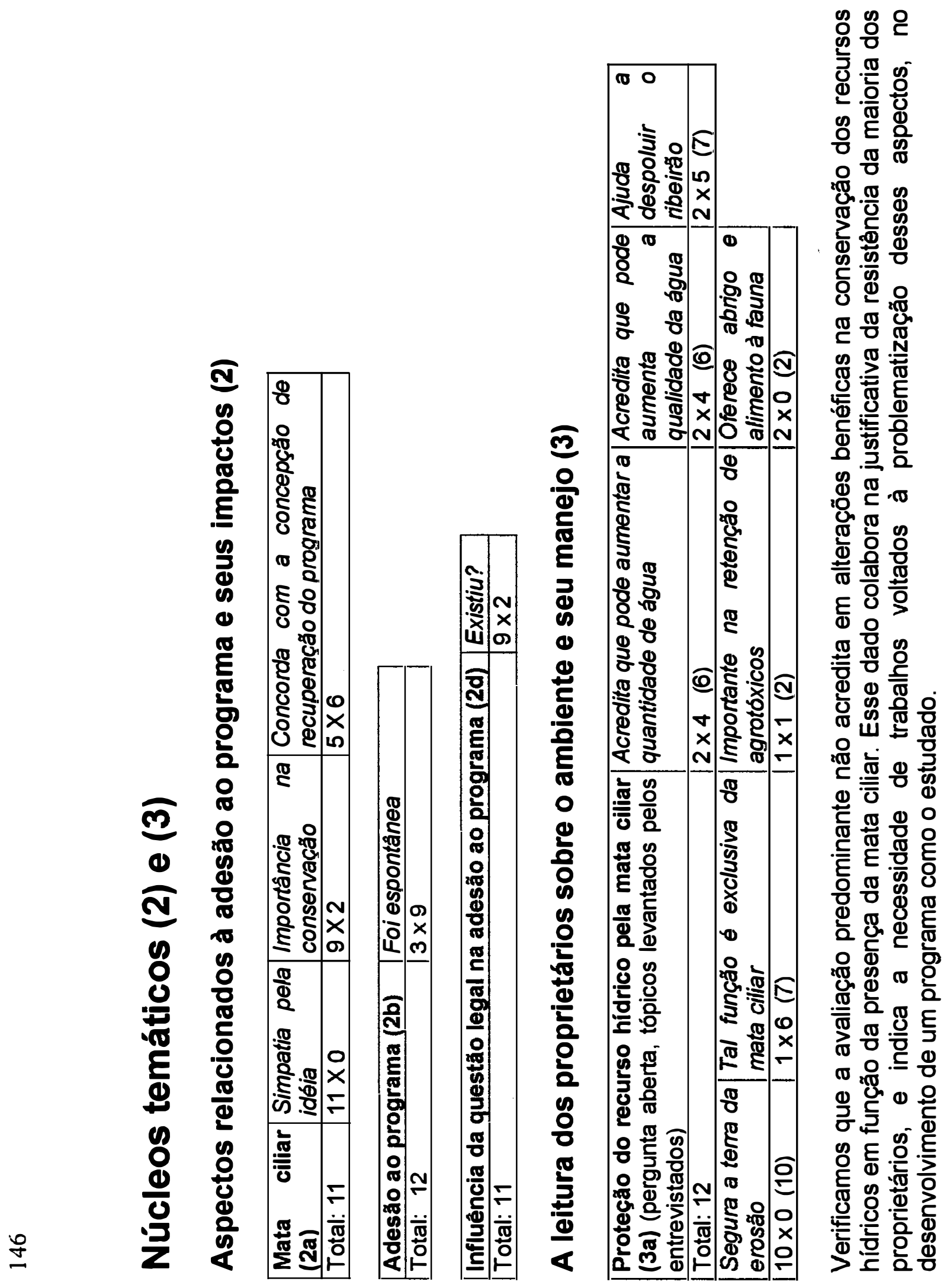




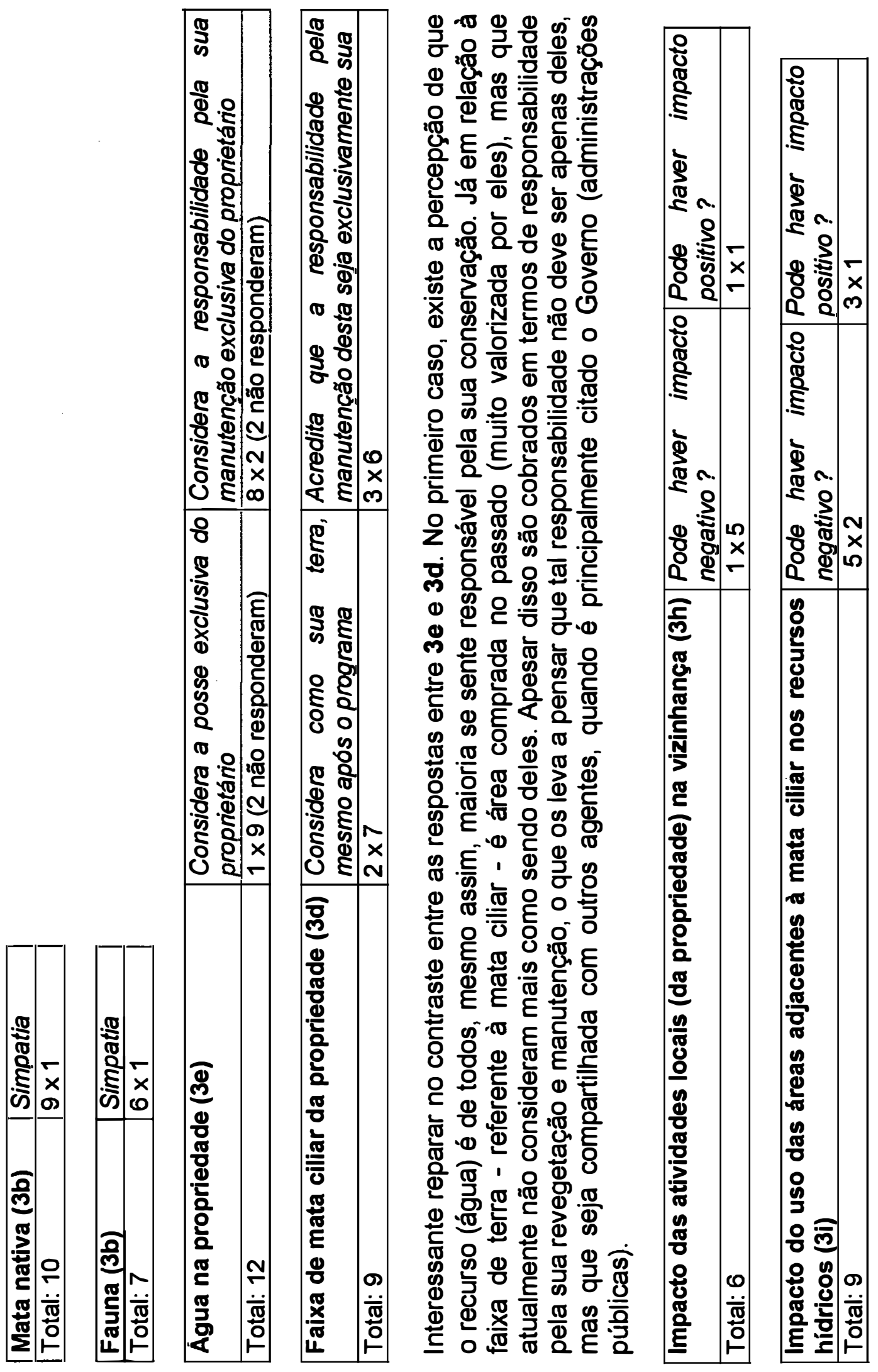




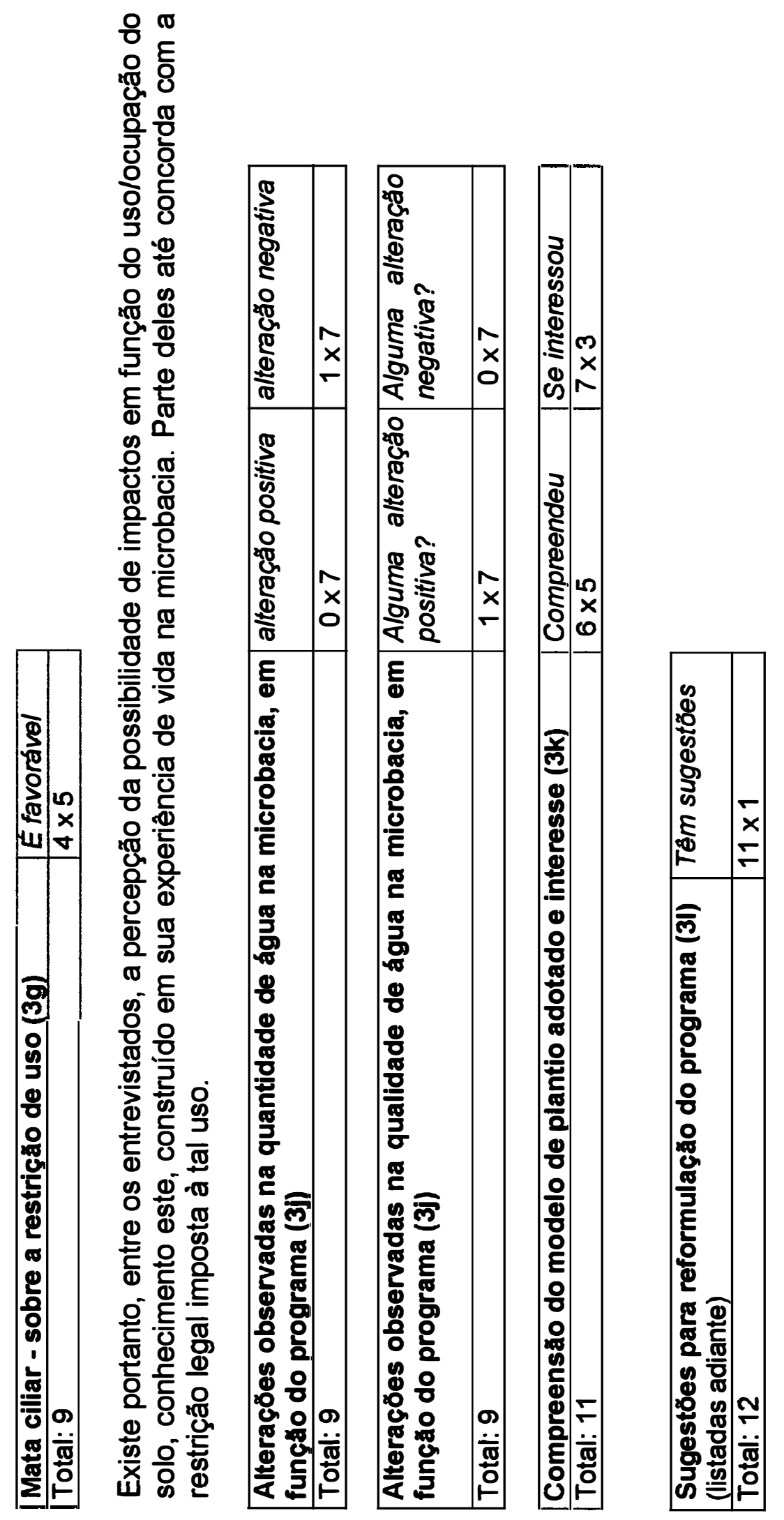




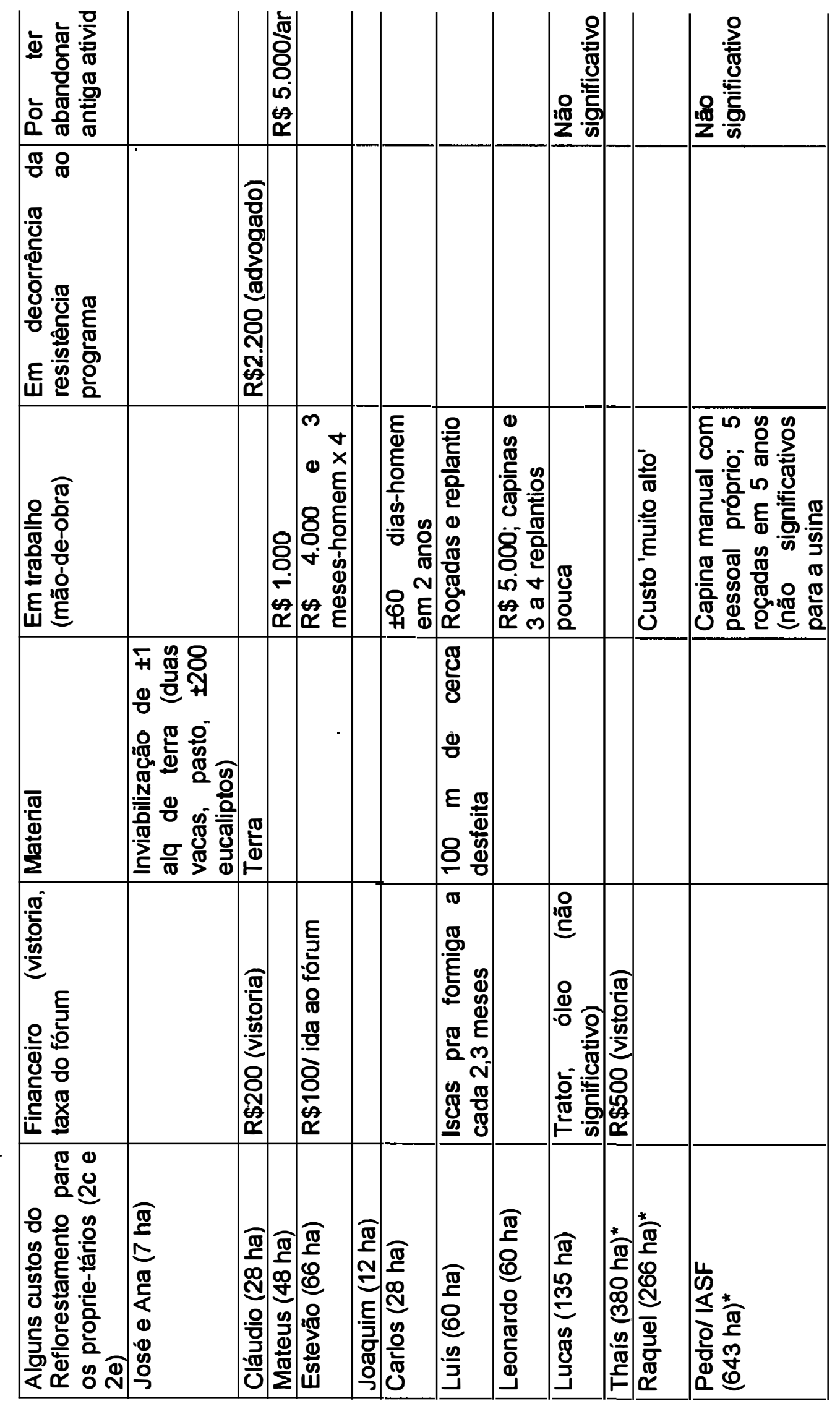




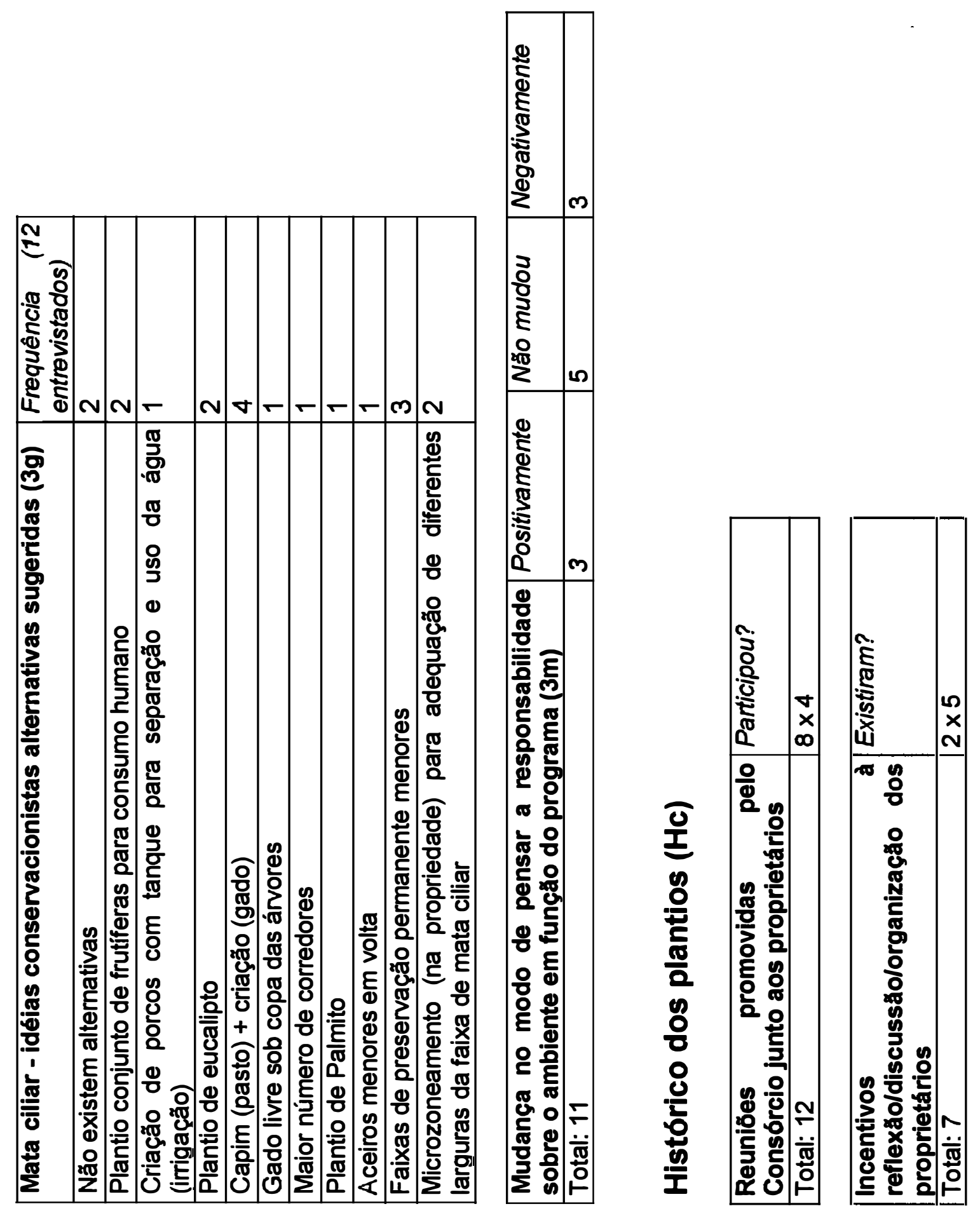



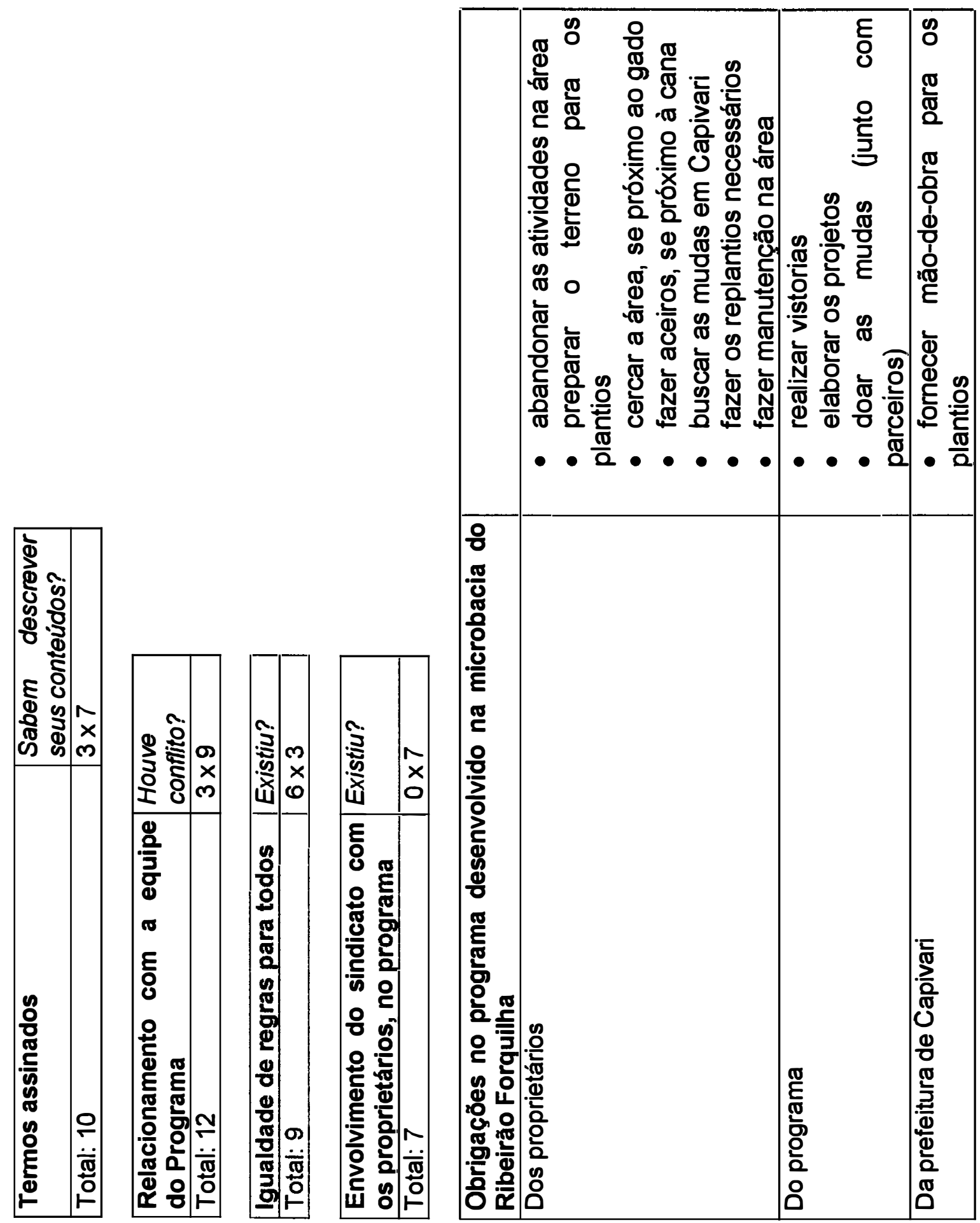


\subsection{Reflorestamentos Ciliares: onde se quer chegar?}

Que resultados são desejados em uma ação de reflorestamento ciliar? Quais são os objetivos de tal ação? Ávores plantadas? Aumento da responsabilidade do proprietário para com a sociedade (habitantes urbanos, instituições públicas, governos municipal, estadual, federal)? Ampliação do compromisso e responsabilidade da sociedade para com o proprietário?

Uma linha de análise que foi sendo construída ao longo deste trabalho e ganhando corpo ao ponto de tornar-se um argumento central nesta dissertação, é a responsabilidade e compromisso entre proprietário rural e as instituições que atuam em seu contexto regional, procurando promover ao mesmo tempo desenvolvimento e conservação de seus recursos naturais.

\subsubsection{Responsabilidades}

O que constatamos foi um quadro de pouca responsabilidade das instituições sociais com a maioria da população, evidenciada nas políticas públicas que privilegiam setores privados, omissões, corrupção, gerando também comportamentos irresponsáveis dessa população para com suas instituições, que por sua vez alimentam uma cultura de contratos de irresponsabilidades, de um lado e de outro, num "equilíbrio" perverso (fig. 9). A lógica capitalista já é, por si, socialmente irresponsável, uma vez que prioriza a boa 'reprodução' e salvaguarda da 'existência' do capital, e não de populações humanas. 
Figura 11. Equilíbrio dinâmico e histórico do grau de responsabilidade entre sociedade e individuos

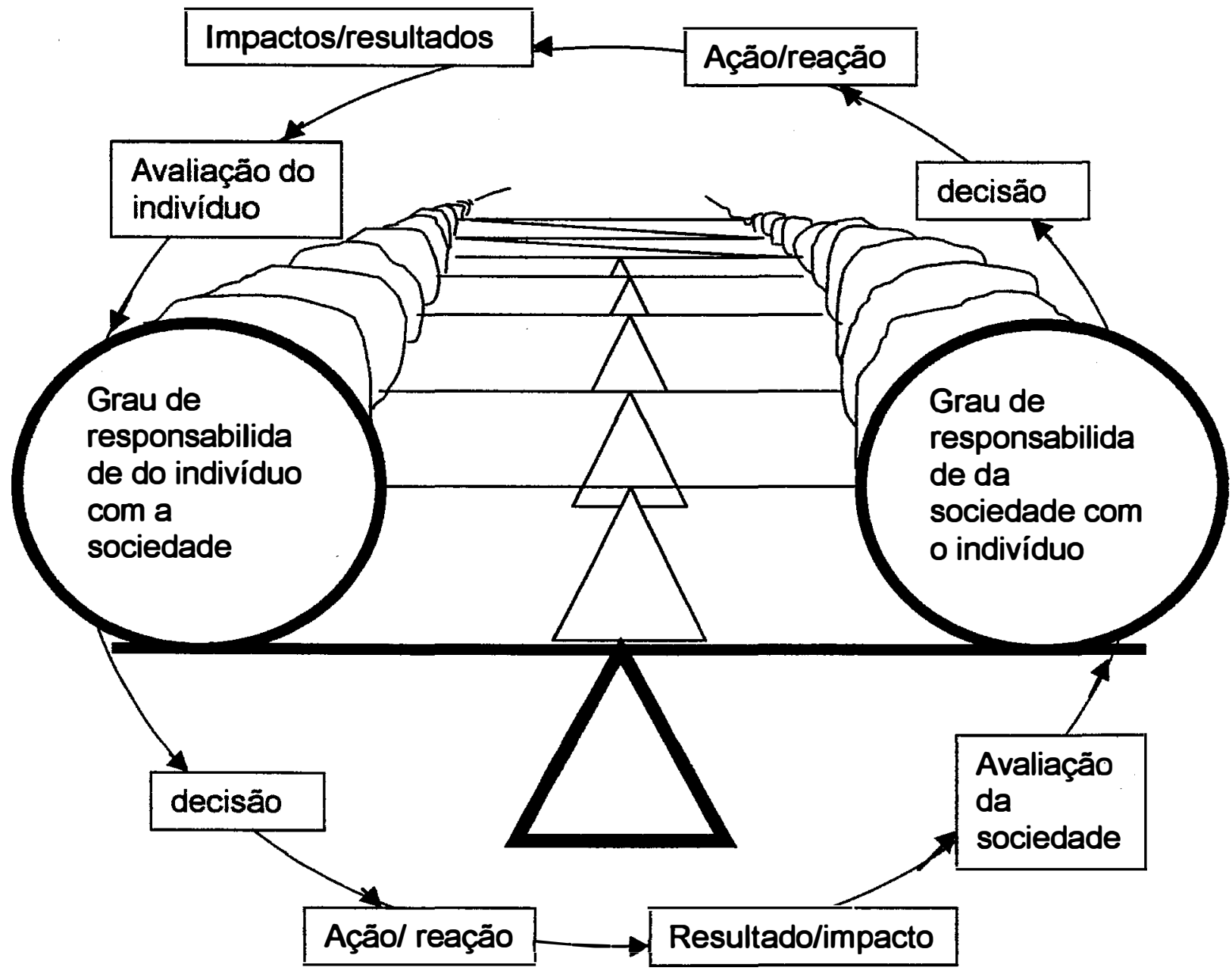


Acreditamos que o rompimento de tal "equilíbrio" seja fundamental para que possamos sonhar com uma sociedade mais justa e que saiba conservar seus recursos naturais. O rompimento poderia se dar por dois caminhos (não excludentes): por iniciativa do(s) indivíduo(s), ou por iniciativa das instituições.

No primeiro caso o indivíduo assume uma postura mais responsável, apesar da cultura de irresponsabilidade onde vive, e busca formas de ampliar/valorizar esse comportamento, buscando parceiros (pessoas ou instituições). Criado tal desequilíbrio ele sente que é necessária, porém, a continuidade e ampliação de sua intervenção - agora no meio institucional (instituições representativas e a serviço da sociedade) cobrando novo nivel de responsabilidade equivalente para que tal movimento não se acabe no equilíbrio anterior (a energia para se romper um equilíbrio é sempre maior que a energia que o mantém, criando assim, um "poder tampão", uma resistência à mudança). Para tanto, ele precisa conhecer bem tais instituições; envolver-se politicamente. E essa iniciativa - inicialmente individual - terá tanto maiores chances de se estabelecer e de transformar o meio, quanto maior for o compartilhamento desses ideais por outros indivíduos ou grupos. Espera-se que o ciclo anterior vá se rompendo, e gerando um novo padrão, agora sobre acordos de responsabilidade mútua.

O outro caminho (que é o que nos interessa analisar), surge da iniciativa de uma instituição a serviço da sociedade (pública, privada, governamental, não-governamental), que superando a atuação fragmentada na realidade, acredita não mais poder alcançar seus objetivos pontuais sem questionar seu grau de responsabilidade com a maioria dos indivíduos. Percebe que seu tema de ação (pontual) não dá conta da complexidade de fatores e de suas interações na vida real, comprometendo seu poder transformador sobre tal realidade. Frente ao desafio de romper com esse ciclo de irresponsabilidades, ela assume o papel de iniciadora da ação necessária. Estabelece parcerias com outras instituições que também desejam um novo 
equilibrio (novo contrato com a sociedade e com a natureza), enxergando no indivíduo (e no fortalecimento dos grupos da qual faz parte), o agente efetivo da transformação e conservação da natureza, que por sua vez, o fará de modo tanto mais responsável, quanto mais responsabilidade ele sentir que a sociedade e suas instituições têm também com ele. Esta instituição propõe um programa, como modo operacional de realizar sua ação de restauração da responsabilidade da sociedade (ela e seus parceiros) com os indivíduos. Ela se preocupa em promover assim, efetivamente, o aumento da responsabilidade do indivíduo com a sociedade, para alcançar novo nivel de equilíbrio. Para tanto, ela precisa conhecer tal indivíduo, e exigir deste um novo padrão de responsabilidade, correspondente.

Quando falo da busca do aumento da responsabilidade do indivíduo para com o seu meio por iniciativa de instituições encontramos diferentes modos de agir, observando a realidade de algumas ações (ditas) ambientais (fig. 10):

a) Numa visão sistêmica (em ciclos que se retroalimentam), espera-se que o comportamento do indivíduo se transforme em resposta à transformação do comportamento da sociedade e suas instituições para com ele (equilibrio dinâmico, ao longo do tempo);

b) Numa visão linear (aceitando a idéia do equilíbrio mas não a estrutura sistêmica de retroalimentação), espera-se que o comportamento do indivíduo se transforme (mais responsável) em resposta ao aumento do poder de repreensão, controle, persuasão e até repressão pelas instituições sociais. 
Fig. 12. Dois caminhos (não excludentes) para se aumentar a responsabilidade do individuo para com a sociedade.
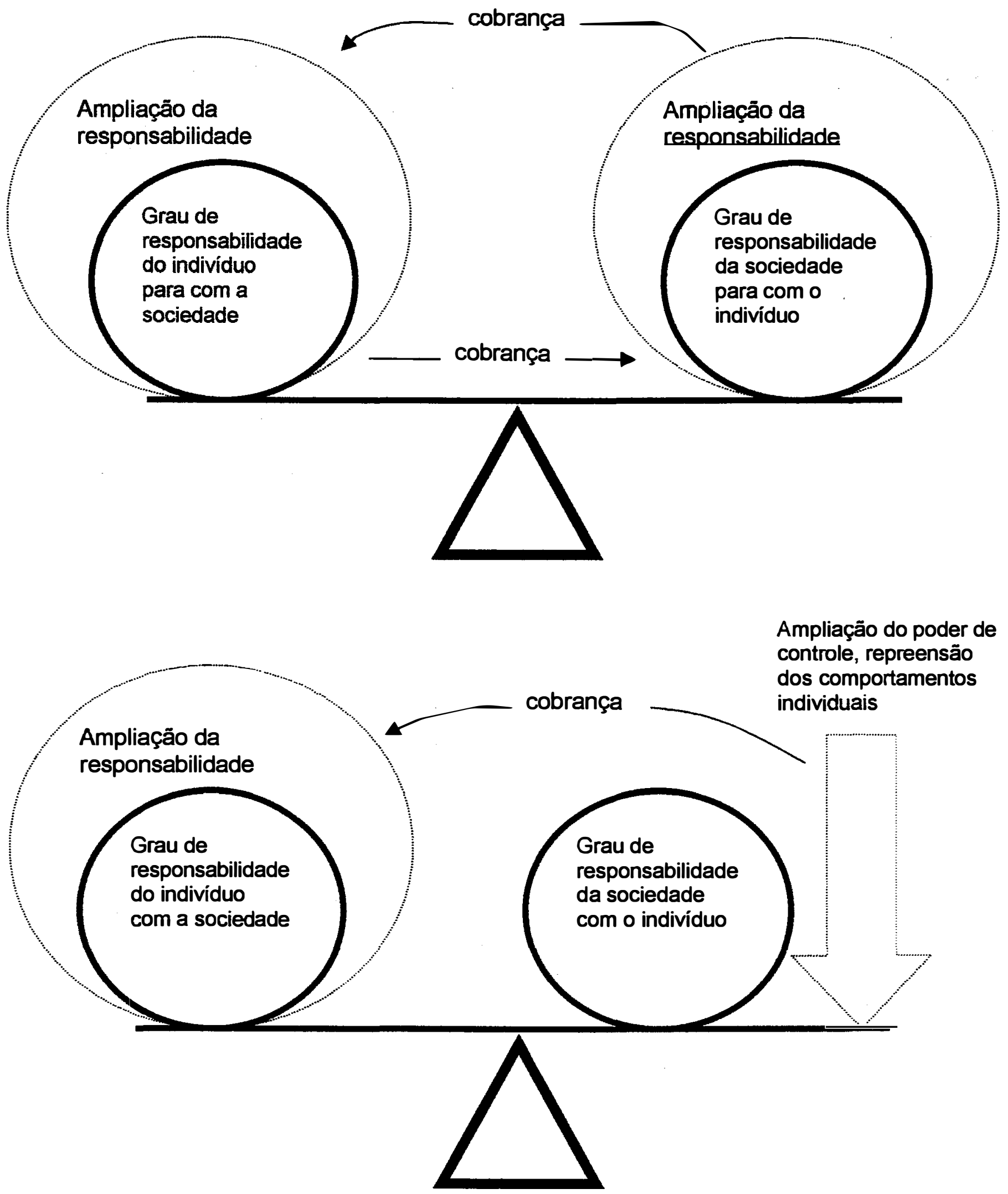
Mas como se traduz o "aumento da responsabilidade das instituições da sociedade para com o indivíduo", na compreensão do processo conforme "a", no contexto de um programa de reflorestamento ciliar?

Pode significar, por exemplo, que as instituições:

- não o esperem chegar até elas, mas procurem-no;

- queiram conhecê-lo (tenha mais interesse por seu modo de viver e de agir);

- passem a não mais desprezar/combater seu saber (popular);

- avaliem-se criticamente e combatam suas omissões (por exemplo, as instituiçōes de pesquisa, de assistência técnica, financeiras, de previdência social, de saúde);

- disponibilizem informação (compartilhando assim, seu poder) com qualidade técnica e política

- viabilizem estruturas para implantação de projetos

- criem/expandam espaços de comunicação, decisão e avaliação (participação)

Esse modo de trabalho implica necessariamente numa relação dialógica, em espaços pensados/criados para incrementar a participação das pessoas.

Obviamente, quanto melhor representados estão os interesses da sociedade em suas instituições (legitimidade dos governos municipal, estadual, federal, fiscais, juizes, serviços públicos como Fundação Florestal, CATI, DEPRN, IBAMA, Universidade, etc) tornam-se mais prováveis a melhoria da comunicação e os trabalhos conjuntos com ela. Maior o nivel de responsabilidade compartilhada. Isso não garante, porém, que as ações sobre o ambiente serão igualmente responsáveis.

O processo pensado pela óptica "b", enxerga o indivíduo como infrator ou não-infrator, segundo a ordem social estabelecida legalmente. Se este indivíduo possuir um comportamento julgado indesejado/inadequado, este deve então ser combatido pelas "autoridades competentes". No contexto de um programa, isso pode significar que a qualidade das informações 
disponibilizadas e das estruturas que viabilizarão a restauraçāo da infração cometida serão julgadas apenas pelos coordenadores da ação, e terão função de diminuir os impactos negativos da ação do programa, se não forem apenas ornamentais.

No programa desenvolvido pelo Consórcio na microbacia do ribeirão Forquilha (em Capivari, SP), a partir de 1991, trabalhou-se com o medo, pelo poder da lei, e posteriormente sinalizou-se com recursos que o programa poderia arrumar junto aos parceiros, de modo que tais recursos fossem encarados como "benefícios" (projetos, mudas e mão-de-obra dos plantios gratuitos). Tal percepção, porém, foi manifestada apenas por uma minoria.

\subsubsection{Opção do programa do Consórcio na microbacia do Forquilha}

Já na leitura dos documentos do Consórcio, pôde-se depreender o que depois foi confirmado no depoimento dos técnicos, que o objetivo específico do programa era a implantação de árvores ("os projetos") na área da faixa ciliar preconizada na lei.

A estrutura do trabalho lá desenvolvido poderia ser entendida dentro do seguinte esquema:

O "querer" dos proprietários: deve ser transformado pela coerção, justificada pela simples existência da lei; isso traz agilidade, economia de recursos e boa imagem ambiental para as instituições envolvidas;

O "poder" dos proprietários, para implementar as ações é variado, mas em termos gerais é baixo. Não viabilizar alguns dos principais recursos seria uma atitude de pouco bom senso, quando se deseja agilidade nas ações; isso seria o motivo central das parcerias, que posteriormente se utilizam de tais ações na autopromoção "em favor do ambiente", sem contudo avaliar criticamente os resultados; 
O "saber" dos proprietários (não todos), é pensado como nulo ou baixo, e seu incremento é pensado via disponibilização mínima de informações (tipo "comunicados"), de qualidade questionável, sobre a legislação e sobre a importância de se revegetar as matas ciliares. Não há via de retorno, do saber dos proprietários para os técnicos, tanto em termos de:

- diagnóstico da crise ambiental;

- método mais adequado de ação, no programa;

- diagnóstico da qualidade dos recursos naturais na microbacia;

- modelos de revegetação e das

- espécies de ocorrência local/locais mais apropriados

Na sequência inversa da estrutura proposta no artigo de Benno Galjart (Galjart,1972) - que sugere uma análise sequencial saber $\rightarrow$ poder $\rightarrow$ querer - , a estrutura de ação do programa quis um comportamento de aceitação obrigatória dos proprietários quanto aos plantios, planejou para tanto parcerias que forneceriam os insumos mais restritivos (segundo sua avaliação, projeto, mudas e mão-de-obra para o plantio), e disponibilizou informações na forma de comunicados, seja de forma coletiva (inicialmente, para comunicar do que se tratava a ação) ou individual - dentro da estratégia de coerção, tipo "saiba o quanto você pode vir a perder se não aderir" (figs. 13 e 14). 
Fig. 13. Análise da estrutura de açăo no programa do Consórcio, na microbacia do Ribeiråo Forquilha em Capivari (SP), na leitura do tempo dos acontecimentos.

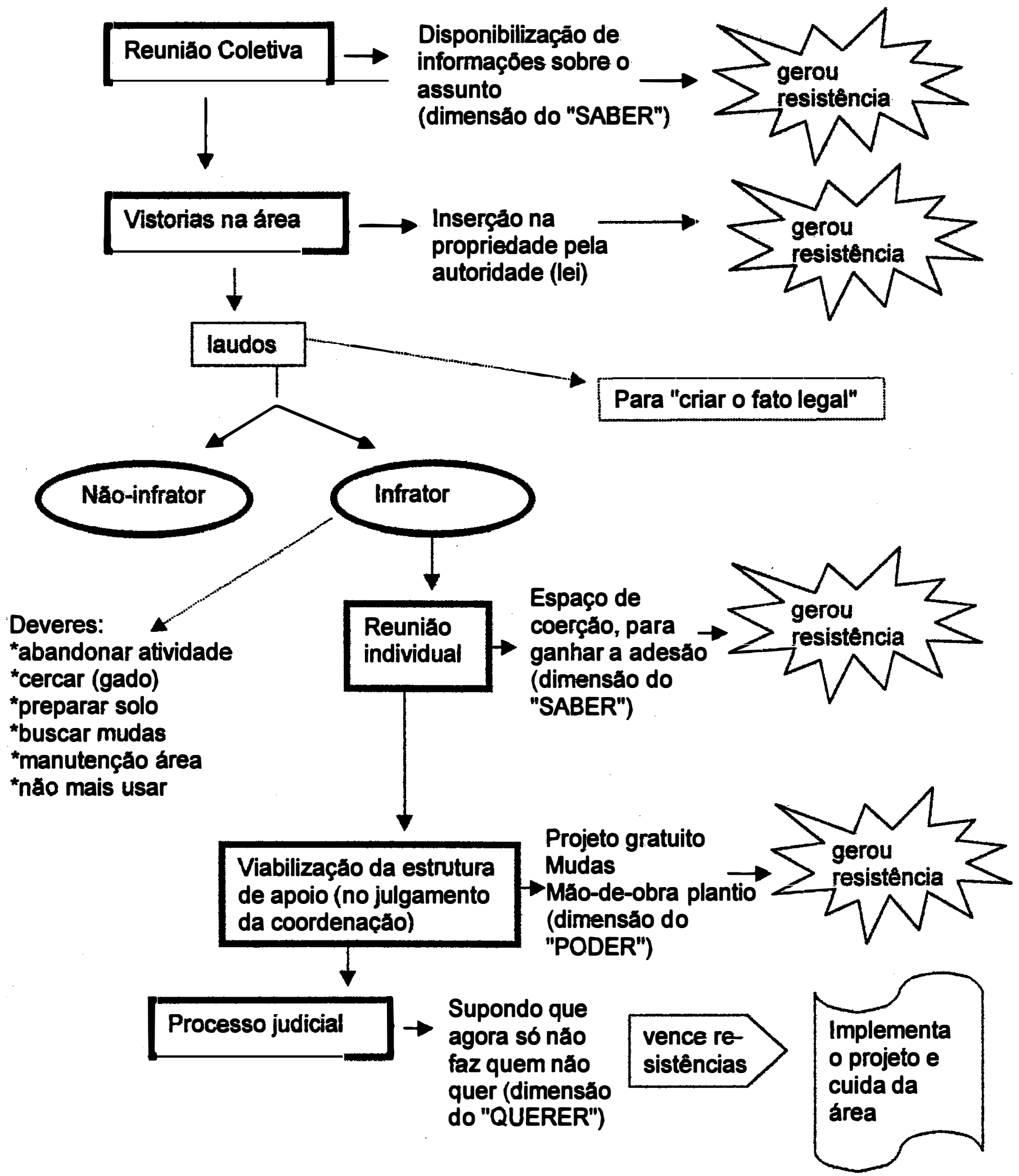


Fig. 14. Análise da estrutura de ação no programa do Consórcio, na microbacia do Ribeirão Forquilha em Capivari (SP), na leitura do tempo do planejamento.

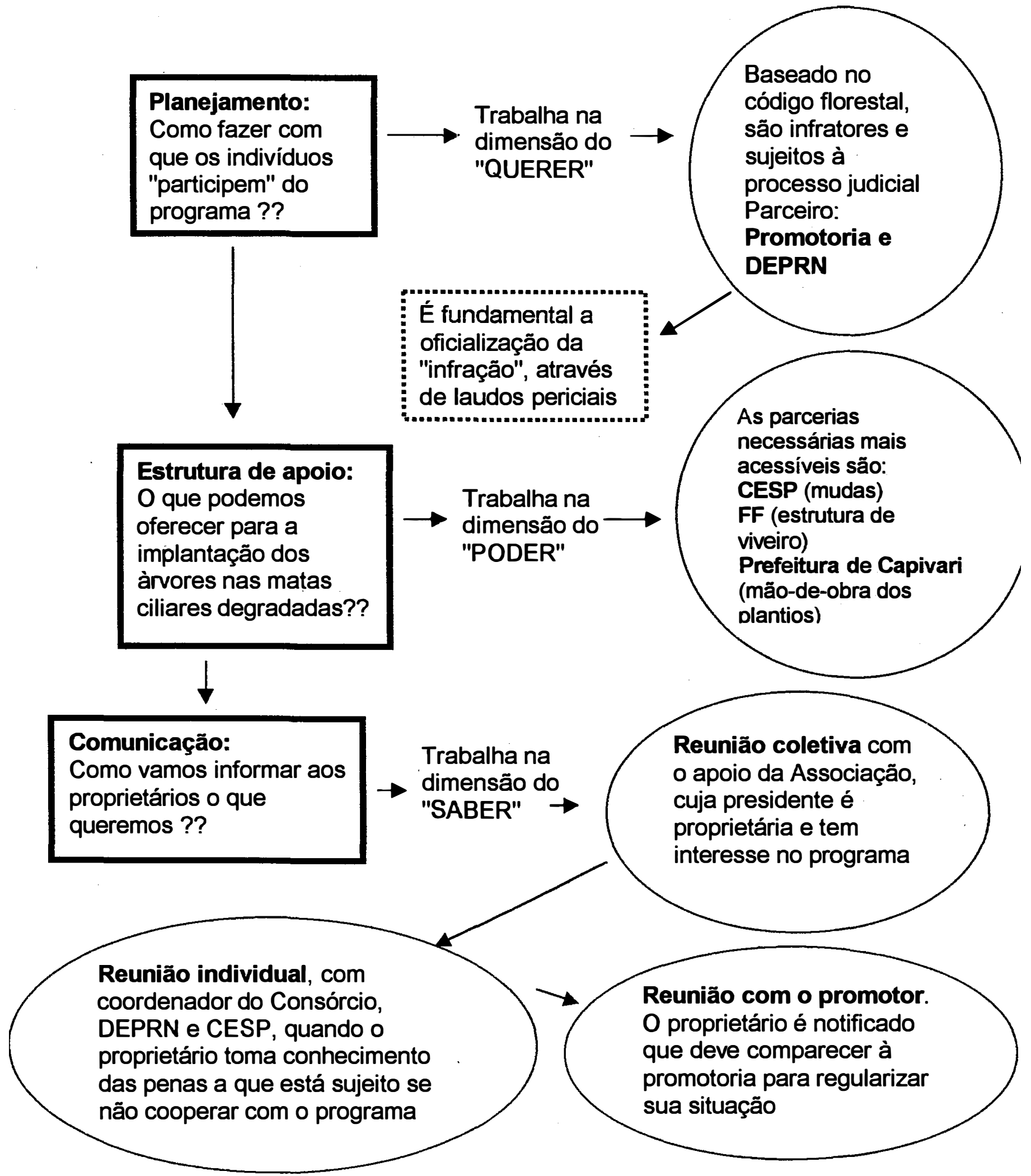


A dimensão do querer, inspirada em Galjart (1972), trouxe desdobramentos na leitura das entrevistas e na confrontação com a obra de Freire (1983).

Para Galjart, a ignorância a respeito de inovações tecnológicas pode ser uma das barreiras à adoção destas tecnologias, cujo enfrentamento se traduziria na disseminação de informações. Se já bem informado, e o comportamento do indivíduo ainda não se modificou no sentido da adoção, então na questão das possibilidades (o como viabilizar a estrutura de apoio necessária) pode estar a solução. Se bem trabalhadas as duas anteriores, resta o campo da vontade para a compreensão da não-adoção, onde caberia uma doutrinação cultural (para mudar os valores julgados inadequados).

Não concordando plenamente com tal pensamento, mas aproveitando a estrutura das três dimensões proposta pelo autor, desenvolvo a seguir algumas consideraçōes:

- A dimensão do "saber" é muito maior que a simples disseminação de informações, entrando no campo da construção de conhecimento, indissociável da dimensão do "querer";

- A dimensão do "querer" não deve ser a etapa final, como proposta, numa estrutura seqüencial lógica linear, mas permear todo o processo, principalmente quando envolve o "saber";

- O lugar da educação (ambiental ou não) não pode ser o da doutrinação cultural de modo a alterar os "quereres", colocada sequencialmente após disseminação de informações e viabilização de estrutura, mas sim o de permear o processo como um todo;

- A estrutura simplificada proposta pelo autor, embora não capte corretamente, ao meu ver, o processo de adoção de novas propostas tecnológicas (pois não leva em conta o processo de construção de conhecimento), colabora para a compreensão da estratégia escolhida pelo Programa. 
No programa desenvolvido em Capivari o julgamento sobre o "querer" (dentro da estrutura linear proposta por Galjart) acabaria ficando a critério dos técnicos (este é ou não adequado), frente aos objetivos que interessaram ao programa. Entrevistas revelaram que os coordenadores, acreditam que tais valores até que poderiam ser trabalhados por frentes educacionais (seguindo a mesma linha de Galjart, de "doutrinação cultural", numa terceira etapa analítica), mas por falta de parceiros e recursos nesse sentido, o Consórcio teria se valido da força da lei, de tal modo a usá-la pontualmente para a coerção dos proprietários no sentido dos seus objetivos.

Porém, é um grande equívoco pensar que uma ação educativa dentro dessa estrutura de trabalho possa obter resultados educativos a favor da realização dos objetivos pontuais de um programa como o realizado no Forquilha. Quais sejam: mudar o comportamento dos proprietários (o "querer"), sensibilizando-os para a importância do saber (dito) científico expresso no código florestal, e para que valorizem os recursos considerados pela coordenação do programa como os limitantes à implantação das matas ciliares.

A própria estrutura proposta e desenvolvida pelo Consórcio no Forquilha dificulta a compreensão das falhas desse esquema de ação. Porém, é necessário ressaltar que os objetivos do Consórcio (árvores no chão) foram alcançados (por volta de 120.000 mudas plantadas, em 7 anos). Teve, portanto sucesso. Assim, o objetivo "árvores plantadas" combinou-se bem com o caminho da coerção, mais adequado à filosofia do Programa e à seu nível de responsabilidade com o proprietário rural, que foi pequeno (senão nulo).

Assim, ressalto que só é possível a compreensão da importância do espaço dialógico nas ações de revegetação ou de adoção do elemento arbóreo na propriedade rural, pela crença no pensamento sistêmico, na construção do conhecimento através da prática cotidiana e no contexto das coresponsabilidades. Portanto, a força da minha argumentação está fragilmente apoiada na aceitação desse pressuposto inicial. Outros caminhos não necessitam de tal abordagem, que provavelmente será fator de "perda de 
tempo" e de "desperdício de recursos", atrapalhando o alcance dos objetivos finais. Esse tema é central na análise que Freire (1983) desenvolve sobre a qualidade da comunicação na extensão rural, esclarecendo o lugar da educação no encontro do técnico com o proprietário rural. É por esse motivo que adotei sua estrutura de análise como uma das referências para esta reflexão, no sentido de contribuir para que os recursos naturais sejam melhor conservados, no contexto do resgate das mútuas responsabilidades entre instituiçōes representativas da sociedade e os indivíduos.

As entrevistas desenvolvidas nesse trabalho de dissertação caracterizaram-se como espaço de manifestação das crenças e avaliaçōes por parte dos proprietários, espaço este, desestimulado e até combatido no desenvolvimento do programa do Consórcio. O conteúdo das entrevistas reforça a adequação da estrutura de análise sugerida na fig.9, onde, mantido o equilíbrio num nível de baixas responsabilidades entre instituições e indivíduo, o meio natural se degrada, e põe em risco a própria existência das pessoas, sejam como indivíduos, seja como sociedade. É por aí que leio a degradação dos recursos naturais: o ser humano construindo sua cultura a partir da transformação irresponsável da natureza, mas também a partir de relações irresponsáveis entre os próprios humanos, onde os interesses de poucos com poder (seja científico, legal, institucional, econômico) se sobressaem aos interesses de muitos sem poder. Essa cultura da irresponsabilidade (como um "poder tampão", num "equilíbrio dinâmico") gera comportamentos individuais irresponsáveis também na maioria das pessoas, justificando seu descomprometimento com 0 bem-geral da sociedade, numa estranha coerência, mas numa grande incoerência com a base de recursos naturais que os sustentam.

Um programa como o desenvolvido na Forquilha, enfrentou o difícil desafio de obter respostas homogêneas (aceitação aos plantios e cooperação para sua sustentação) partindo de uma proposta dita homogênea 
(igual para todos), num ambiente de grande diversidade de histórias de vida, condições e interesses.

Listo a seguir alguns desses aspectos a partir da contribuição dos entrevistados - a área da propriedade refere-se apenas às terras dentro dos limites da microbacia, indicada com asterisco $\left(^{*}\right)$ quando na realidade é maior, e os extrapola; \% de mc é a \% da área da propriedade que foi ocupada com os plantios do programa, e \% de fragm é a \% da área da propriedade que já estava ocupada por pastos sujos, capoeiras ou florestas.

\section{Usina}

\section{IASF (643 ha)*}

$$
\text { ( } \sim 3 \% \mathrm{mc}, \sim 20 \% \text { fragm })
$$

Têm Interesse na "imagem verde" (fins comerciais).

Conhecem a lei e as consequências financeiras de um processo judicial

Teria custos menores com o apoio do programa (do que se fizesse sozinha) Grande parte das MCs estão nas "barrocas" onde a mecanização não chega, sendo áreas menos nobres. Alto uso de mecanização.

\section{Presidente da Associação}

Raquel (266 ha) ${ }^{\star}$

( $2 \% \mathrm{mc},>10 \%$ fragm)

Tem interesse na "imagem verde", tanto para a Associação como para si própria, como sinalizou em 1992, na reportagem do Suplemento Agrícola do jornal "O Estado de S. Paulo" (de 30/09/92).

É proprietária de área onde está a represa, pensando em desenvolver futuramente um projeto de paisagismo.

O programa oferece um custo menor para um trabalho que já lhe interessava. Ela usa a água da represa para irrigação, e assim interessa-lhe a minimização das taxas de assoreamento. Alto uso de mecanização.

\section{Grandes proprietários}

Thaís (380 ha)*

( $2 \% \mathrm{mc},>10 \%$ fragm $)$ 
Lucas (135 ha) $)^{*}$

$(\sim 1 \% \mathrm{mc},<10 \%$ fragm $)$

A área que foi tomada é pouca (só "barroca").

MC não é prioridade (não vêem vantagens, ao contrário dos dois primeiros).

Conhecem a lei e sabem que poderia ser pior. Alto uso de mecanização.

Médios que vivem na propriedade

Estevão (66 ha) - muito crítico ao programa ( $\quad$ ( $5 \% \mathrm{mc},<5 \%$ fragm)

Luís (60 ha) - aposentado

( $1 \% \mathrm{mc}, \sim 20 \%$ fragm)

Mateus (48 ha)- conservacionista

( $<5 \% \mathrm{mc}, \sim 10 \%$ fragm)

Conflito por área. Vivem da renda da propriedade ou ela é principal fonte de renda. Críticas ao abandono do governo e reclamaçōes pela falta de área (terras) e de alternativas econômicas. Algum conhecimento da lei.

Médio que não vive na propriedade

Leonardo (60 ha) (5\% mc, $\sim 2 \%$ fragm)

Muito crítico ao programa. Comerciante (dono de supermercado), irritado com o programa, considera incoerente a ação. Algum conhecimento da lei.

Pequenos que vivem na propriedade

Cláudio (28 ha) - grande revolta $\quad$ (>10\% $\mathrm{mc},<10 \%$ fragm)

José (7 ha) - aposentado (>20\% mc, 0\% fragm)

Pouco conhecimento da lei. Área é sinônimo de renda. Parte da área de MC sendo utilizada para lazer e/ou cultivo/criação de subsistência. Dizem viver no "aperto". São críticos ao programa. Sentem que perderam qualidade de vida com o programa, que avaliam negativamente.

Pequenos que não vivem na propriedade

Carlos

( $2 \% \mathrm{mc},<5 \%$ fragm)

Joaquim

(<5\% mc, >10\% fragm) 
Estão aposentados. Moram na cidade, mas gostam do campo. Pouco conhecimento da lei. Têm algumas críticas ao programa, mas não foram contra seu desenvolvimento.

Perfis tão diferentes responderam diferentemente à proposta do Consórcio, conforme o interesse próprio e suas condições de vida e produção. Mais que isso, as entrevistas revelaram diferentes crenças quanto à importância da árvore, que justificassem sua implantação/uso na propriedade, além de revelar a diversidade disso que estamos chamando de "importância" das árvores na propriedade. Apresento a seguir, com base na percepção dos entrevistados e na literatura consultada, uma categorização da diversidade de leituras sobre a importância das árvores.

\section{Importância das árvores associadas à mata ciliar}

(Conservação)

Hidrológica

Proteção à flora e fauna e sua conservação genética

Melhoria da qualidade do ar

(Produção)

Produtos não-madeireiros como mel, frutos, plantas medicinais

(Tarifas)

Redução de impostos (ITR)

(Marketing)

Melhoria da imagem do proprietário e/ou da propriedade, valorizado socialmente (benefícios não individuais), culturalmente (apoio à conservação da natureza) e economicamente (mecanismos de certificação em perspectiva) 
(Estética)

embelezamento da propriedade/região

Importância das árvores associadas à reserva florestal legal

(Hidrológica)

Dependendo da localização, melhor infiltração e alimentação dos lençóis freáticos

(Produção madeireira comercial)

Lenha, carvão, mourão, shitake, móveis, caixotaria, etc

(Produção madeireira para consumo)

Lenha, mourão, shitake

(Produção não-madeireira comercial)

óleos essenciais, resinas

(Tarifas)

Redução de impostos (ITR)

(Produção não-madeireira para consumo)

Inicialmente, junto ao crescimento das árvores, pode ser aproveitada alguma produção agropecuária em sistemas agroflorestais ou agrosilvopastoris, com vantagens para o desenvolvimento das arbóreas.

Importância das árvores isoladas ou em grupos, fora do contexto das MCs ou da RL

(Produção)

Em pomar, frutas 
(Melhoria da qualidade do microambiente)

Produção de sombra, temperaturas mais amenas, melhoria da qualidade do ar

(Interesse paisagístico)

Embelezamento da propriedade

(Diversos)

Usos medicinais, artesanatos, para confecção de ferramentas, mourão, construções rurais

\section{Importância geral das árvores}

(Ecológica)

Maior estabilidade ecológica, com incremento da diversidade e de seu equilíbrio, contribuindo para a otimização dos sistemas produtivos da propriedade

Obs: a perspectiva do uso de essências florestais nativas nas reservas florestais (visando o uso econômico) e de sistemas agroflorestais (SAFs) em quaisquer destas modalidades de importância (seja para reduzir os custos e favorecer as condições ecológicas da implantação das árvores, seja pela adequação destes sistemas para o contexto produtivo da propriedade como um todo), ampliam e tornam pouco precisos os limites entre as categorias de importância listadas anteriormente.

Procedeu-se uma análise das entrevistas, buscando colecionar as crenças daqueles proprietários (seu "saber") quanto a "importância na conservação dos recursos hídricos", de modo a compreender a influência desse fator na construção de suas avaliações do programa (tabulações de outros temas são apresentadas mais adiante).

O resultado é mostrado a seguir, juntamente com a tabela resumida que o gerou (tabela 4): 
(Legenda: "A" significa que acredita e "nA" significa que não acredita. Nas avaliações: "+" é positiva, "0" é indiferente e "-" é negativa, com seu graus de intensidade avaliados a partir das entrevistas)

Público Categorias Avaliação do programa Projeto Fragm.

Funcionário da Usina

IASF

A

0

$\sim 3 \% \mathrm{mc} \quad \sim 20 \%$ fragm

Presidente da Associação

Raquel A

$++\quad \sim 2 \% \mathrm{mc} \quad>10 \%$ fragm

Grandes proprietários

Thaís

A

0

Lucas

A

0

$\sim 2 \% \mathrm{mc} \quad>10 \%$ fragm

$\sim 1 \% \mathrm{mc} \quad<10 \%$ fragm

Médios que vivem na propriedade

$\begin{array}{llllr}\text { Estevão } & \mathrm{A} & - & <5 \% \mathrm{mc} & <5 \% \text { fragm } \\ \text { Luís } & \mathrm{A} & - & \sim 1 \% \mathrm{mc} & \sim 20 \% \text { fragm } \\ \text { Mateus } & \mathrm{A} & 0 & <5 \% \mathrm{mc} & \sim 10 \% \text { fragm }\end{array}$

Médio que não vive na propriedade

Leonardo nA

$5 \% \mathrm{mc}$

$\sim 2 \%$ fragm

Pequenos que vivem na propriedade

Cláudio A

José

nA
- $\quad>10 \% \mathrm{mc}$

$>20 \% \mathrm{mc}$
$<10 \%$ fragm

$0 \%$ fragm

Pequenos que não vivem na propriedade

Carlos

Joaquim
A

A

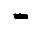

0 $\sim 2 \% \mathrm{mc} \quad<5 \%$ fragm

$<5 \% \mathrm{mc} \quad>10 \%$ fragm 


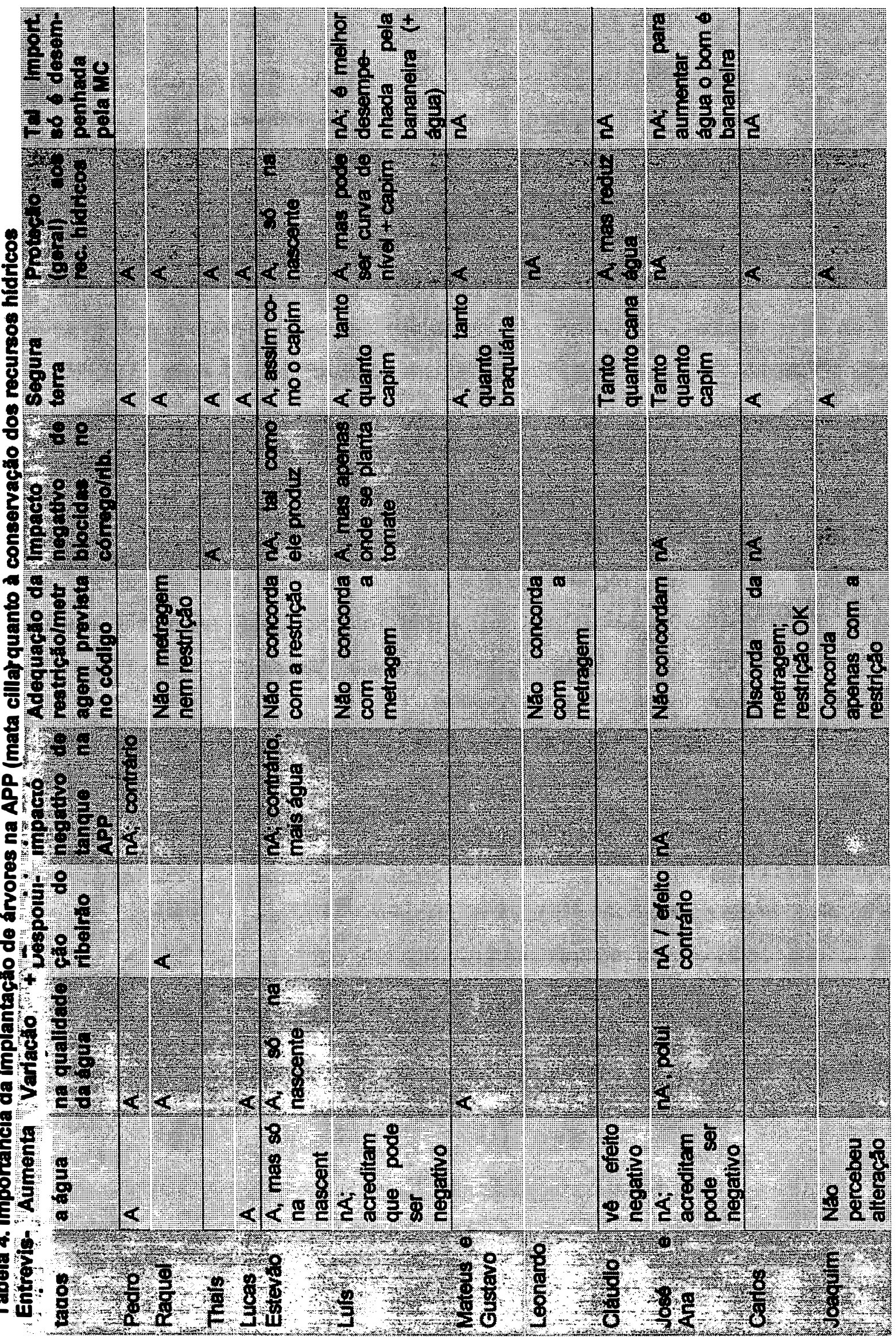


Não foi possivel avaliar sua disposição/vontade em conhecer mais sobre o assunto (seu "querer"), pela grande influência do programa desenvolvido entre eles. Suas possibilidades em priorizar um envolvimento maior na busca de tais informações (avaliação mais subjetiva, do "poder"), também não puderam ser avaliadas.

Acredito que tais aspectos existam de modo simultâneo na mente dos proprietários, conhecimento, vontade de conhecer e avaliação de suas possibilidades para trabalhar melhor esse conhecimento. Nenhum deles é rígido, embora venha sendo construído e reavaliado ao longo de toda uma experiência de vida. A esse conjunto (saber atual, querer saber mais, querer poder saber mais) estabeleço uma ligação com a dimensão que Galjart chama de "saber". Entendo ser uma fase inicial, onde a qualidade do 'confronto das verdades' científicas, legais, políticas com as populares, não-formais, experienciais, determinará o grau de transformação deste pela intervenção daquele, mas também o grau de transformação daquele pela intervenção deste, que não será mais ignorado nem reprimido.

De volta à Galjart, arrisco uma adaptação das dimensões por ele sugeridas, ao contexto da construção de conhecimento, e sua importância no processo de formulação de uma proposta responsável e viável, junto aos proprietários rurais (figs. 15 e 16). Tal processo se daria dentro de um processo sistêmico, onde há retroalimentação, e portanto resultados transformadores e sinérgicos (pelos efeitos multiplicadores, junto aos vizinhos, instituições, mídia). 


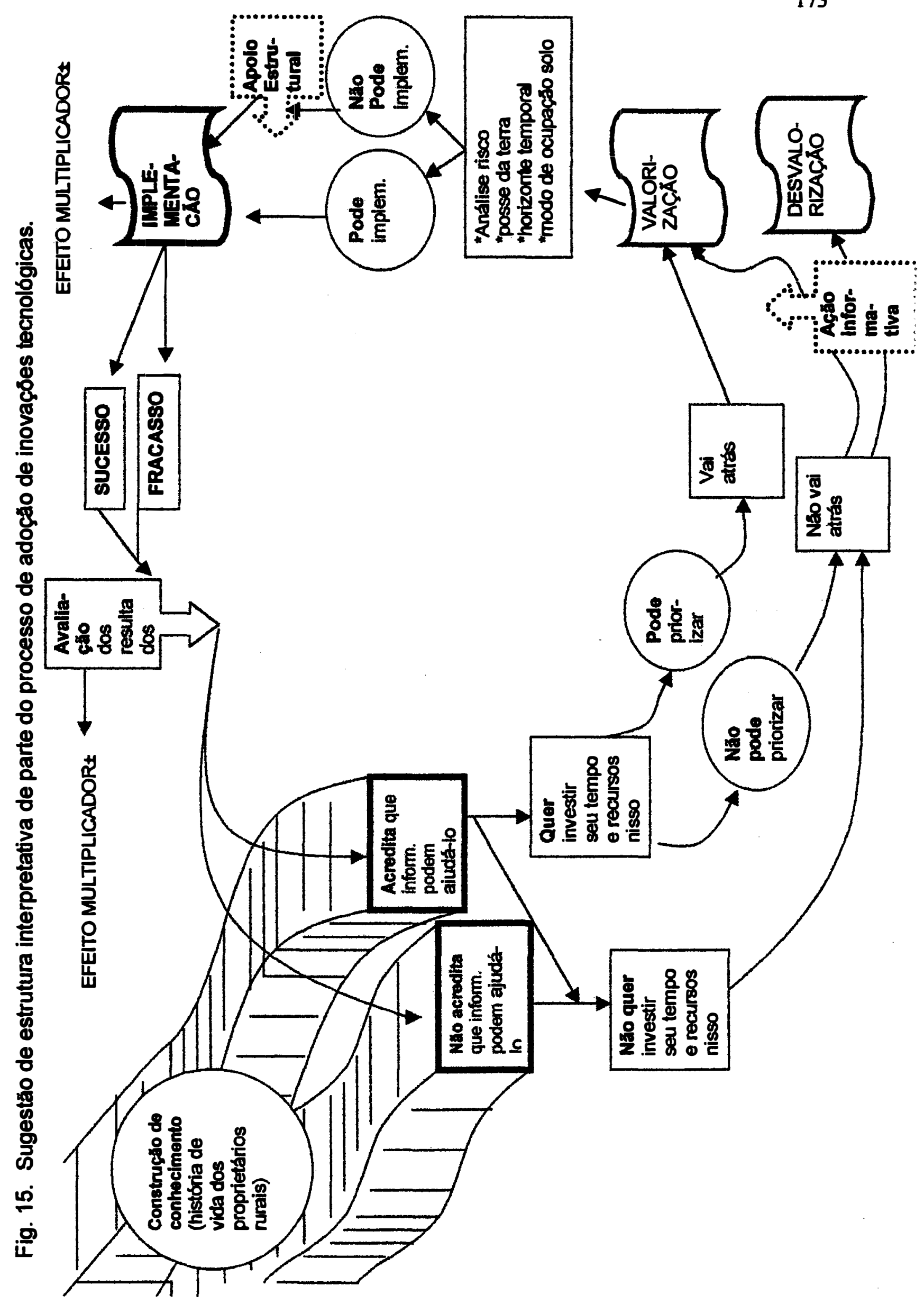




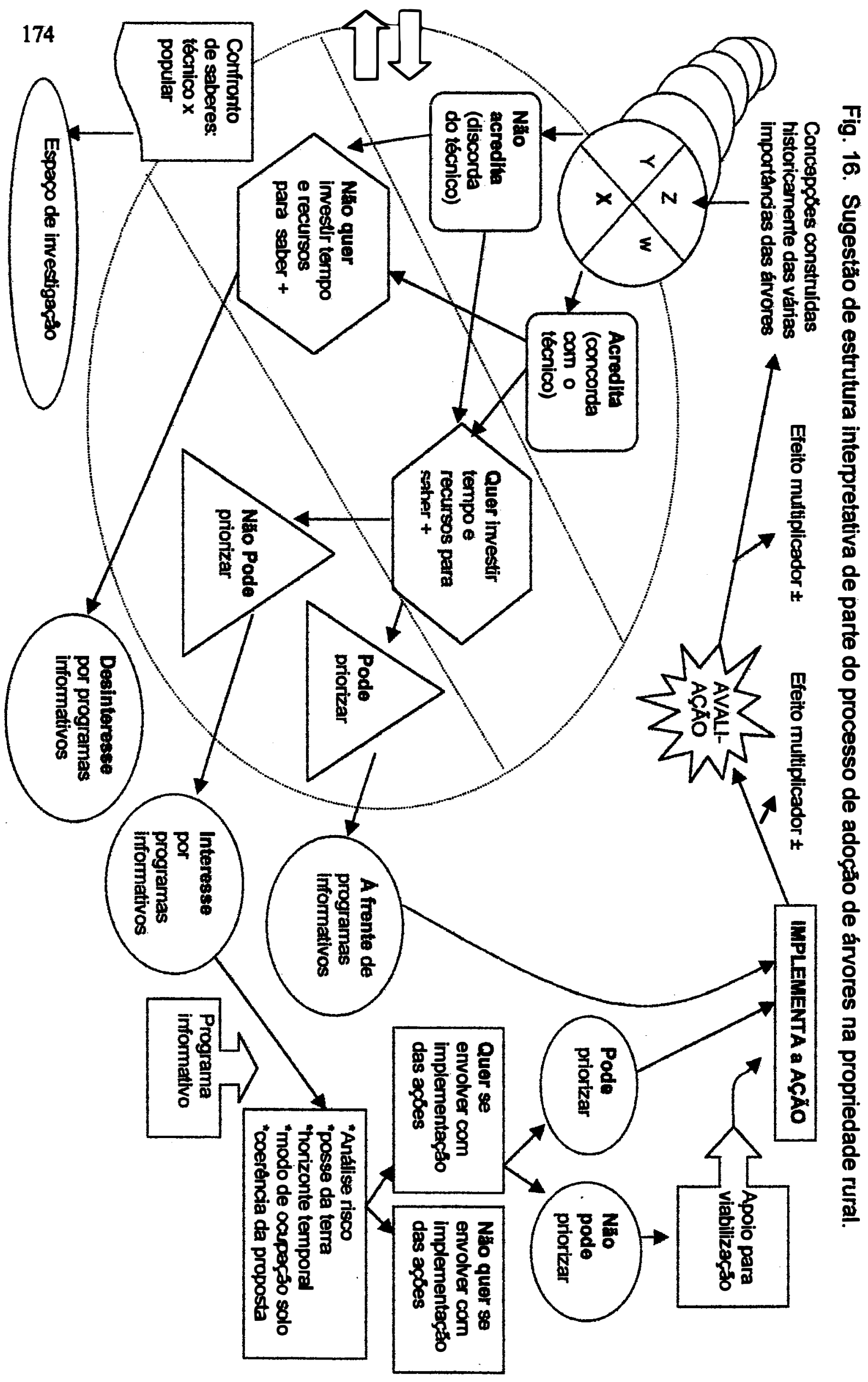


Perceba como o uso da força da lei (DEPRN avalia através dos laudos de campo que o Código Florestal está sendo desrespeitado e cobra da Curadoria Ambiental providências, que podem culminar em Ação Civil Pública, caso o infrator não se sujeite aos acordos oferecidos - leia-se, projetos de plantio do Consórcio) de modo a tornar prioridade o que não era até então, enterra a leitura de todo um campo que acreditamos ser muito rico para a busca de soluções efetivas para o problema da escassa cobertura florestal no Estado, enterrando junto, as chances de um trabalho construtivo e responsável, pois compromete o espaço de liberdade (sem o qual não sobrevive uma proposta pedagógica transformadora). A figura a seguir ilustra um processo nãodialógico, similar ao programa aqui estudado.

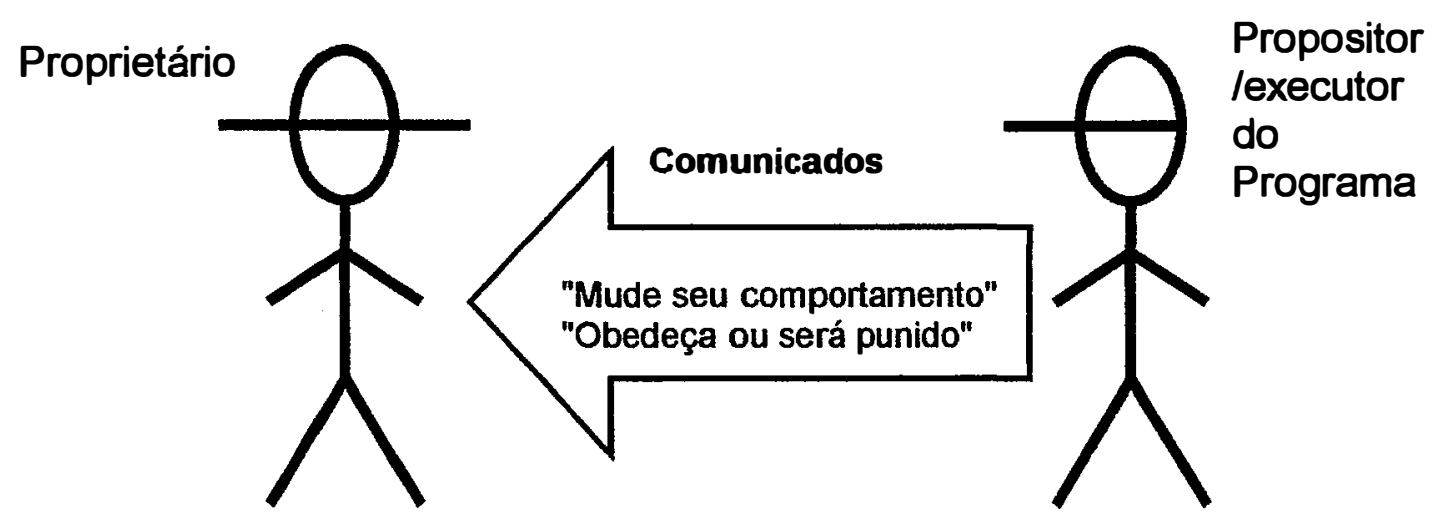

Visto como:

"degradador"; "ignorante"

Visto como:

Poder (com a lei e a ciência)

Figura 17. Relação de mão-única entre proprietário e agente do Programa. 
Fundamental portanto, a valorização da comunicação entre técnicos e proprietários, que permite a participação dos proprietários (coresponsáveis pela sustentabilidade dos projetos) na canstruçāo e nas avaliaçōes de todo o processo, e garantem, assim, melhores chances de sucesso. Isso significa diálogo entre o conhecimento destes dois atores, construindo uma nova qualidade de conhecimento, diferente da inicial, e superior a ela, em termos de compreensão da realidade. Daí o destaque para as questões: 'quem é o público-alvo?' e 'o que estamos entendendo por sucesso do programa?!. Um processo de implantação de mudanças envolvendo substancialmente o proprietário rural - que não é precedido por (ou desenvolvido simultaneamente a) um processo investigativo, inclusive sobre esse mesmo proprietário rural, compromete até a concretização de parâmetros técnicos. No nosso caso, levantamos apenas quatro áreas de conhecimento, presentes no desenvolvimento do programa, que poderiam ser trabalhadas em diálogo com os proprietários (fig. 18). Estão descritas em Construção de conhecimento (1.1.3.), Capitulo 1.

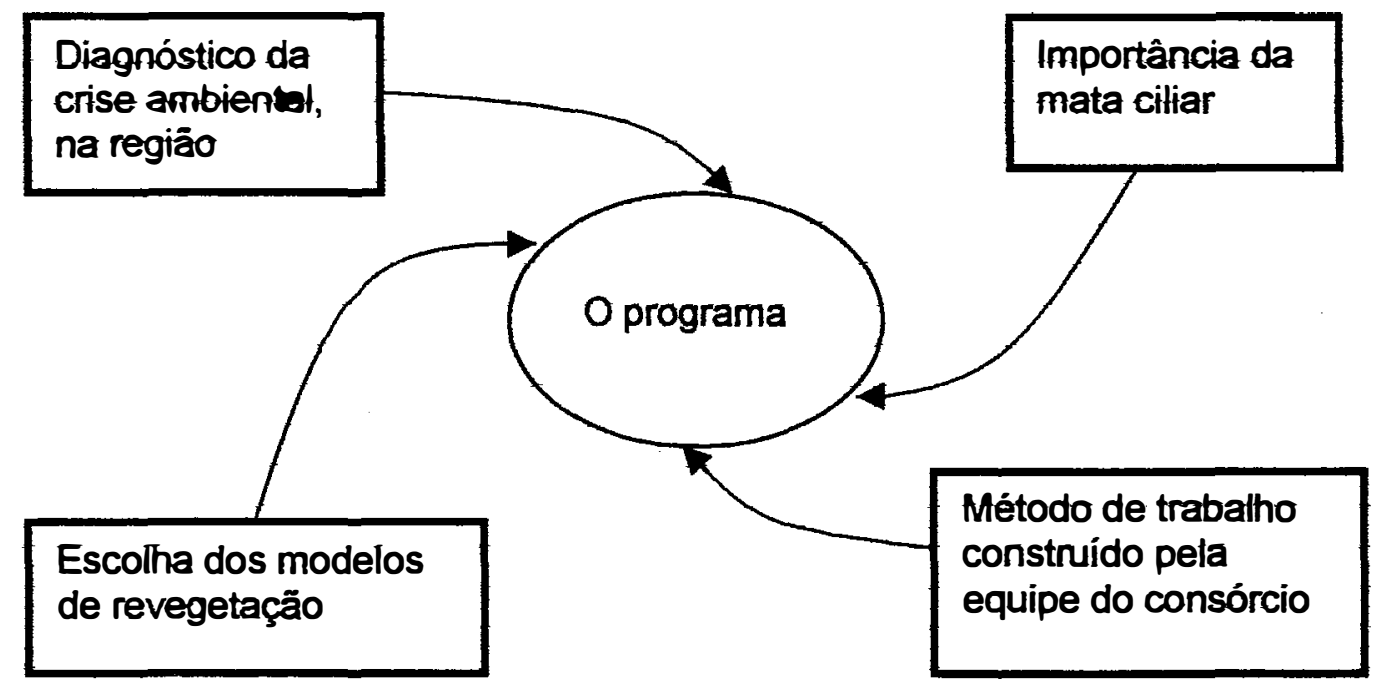

Figura 18. Algumas das áreas de conhecimento envolvidas no Programa. 
O envolvimento dos proprietários na investigação/pesquisa de tais assuntos é uma forma privilegiada de fortalecer sua participação. Encontramos, assim, muitas justificativas para a existência do componente participativo ${ }^{1} \mathrm{em}$ um programa de reflorestamento ciliar. Entre elas:

\section{Para ajudar a equipe técnica...}

a) ... na compreensão do ambiente local/ regional:

- solos (encharcamento, fertilidade,...);

- clima (época mais adequada ao plantio, geadas, ...);

- ocorrência de espécies locais/regionais (melhor adaptação,...);

- intensidade e qualidade da regeneração natural;

- fauna (dispersão, herbivoria, ...);

- impactos atuais sobre a qualidade da água (poluição, assoreamento,...);

b) ... na execução do plantio:

- local e preparo do solo (calagem, adubação,...);

- mão-de-obra;

- para compreender o calendário agrícola da propriedade;

- escolha do espaçamento mais adequado ao contexto (capinas,...);

- coleta de sementes para o viveiro;

c) ... na compreensão do contexto social, cultural e econômico em que a propriedade se encontra, que influenciam/determinam 0 modo de administração, a racionalidade, e assim, as decisões do proprietário.

\section{Para que o(a) proprietário(a)...}

\footnotetext{
${ }^{1}$ Sobre pesquisa participante, veja Freire (1982), Thiollent (1984), Chambers et al. (1989), Edwards (1993), Machado \& Rodrigues (1995).
} 
a) ... seja co-responsável pela decisão de plantar árvores em sua propriedade (RL e/ou em APP);

b) ... goste da idéia de ser o responsável pela manutenção da qualidade ambiental em sua propriedade, sensibilizando-o a preocupar-se e envolverse cada vez mais em niveis de análise crescentes (microbacia, região, estado...);

c) ... tenha benefícios evidentes nesse trabalho de conservação:

- $\quad$ isenção de impostos sobre a área (ITR);

- retorno econômico ou "só pra uso" (mel, palmito, banana, jaboticaba, goiaba, madeira...);

- $\quad$ escolha do modelo mais adequado à sua situação;

d) ... tenha voz e poder de decisão nos acordos firmados, juntamente com outros proprietários, que fortalecidos terão maior poder de pressão para a cobrança do cumprimento das responsabilidades das instituições públicas relacionadas ao desenvolvimento rural regional;

e) ... tenha condições de fazer a manutenção dessa área, sem precisar ser pressionado:

- pensando a adequação do gado entre os plantios;

- prezando pela prevenção de acidentes com o fogo usado na cana;

- controlando a braquiária;

- controlando formigas cortadeiras;

- atento às doenças que possam vir a se desenvolver entre o plantio.

Para que o conhecimento sobre revegetação... 
a) ... possa ser continuamente desenvolvido e melhorado, incluindo-se agora aspectos sociais, culturais, e econômicos, no nível da propriedade agrícola (metragem, espécies, abordagem, conservação genética, efeitos hidrológicos,...);

b) ... seja apreendido pelo agricultor, assim como o conhecimento relativo ao diagnóstico de sua situação ambiental, relativo aos plantios e sua importância; ele precisa se sentir estimulado a desenvolver o hábito cotidiano da pesquisa sobre sua mata;

c) ... não seja usado como mais um pacote tecnológico, em nome da salvação urgente do ambiente (assim como foram os pacotes da revolução verde na década de 70 , em nome da produtividade e do aumento da qualidade de vida) mas contribua para a formação crítica e criativa de técnicos, agricultores e universidade;

d) ... consiga sensibilizar os legisladores e ambientalistas da necessidade de mudança na forma de se encarar o produtor rural (de degradador pra agente de resgate da qualidade ambiental no meio rural), e assim rever as estratégias legais que vem sendo usadas de modo coercitivo (sob ameaça de processo judicial), injusto ('dois pesos, duas medidas') e excludente (prestígio e recursos direcionados à alguns grupos de interesse).

Apresentamos a seguir uma estrutura de análise que procura amarrar todos esses aspectos de forma orgânica, representada na figura 19. Mapeando a teia de relações, a partir dos elementos levantados nas entrevistas e na pesquisa documental, procuro mostrar a inserção das entrevistas (indexadas a seguir, e apresentadas em Anexos $A$ e $B$ ), atribuindo a cada item, uma posição onde foi mais esclarecedora, na direção dos argumentos aqui levantados. 


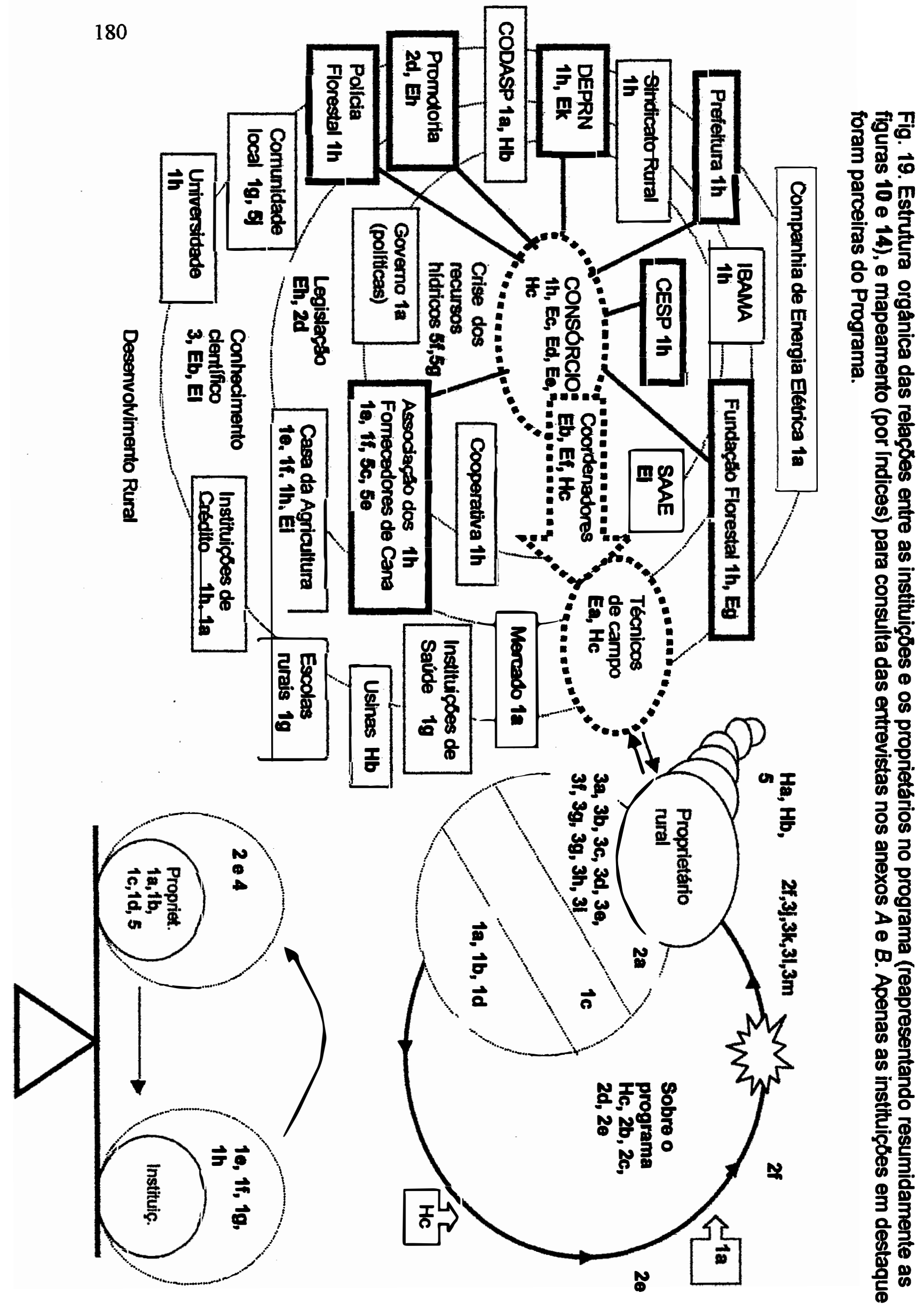


$\mathrm{Na}$ figura 19, destaco em negrito as instituições que fizeram parte da experiência desenvolvida na microbacia do Forquilha, em Capivari. Documentos oficiais sobre o programa (geral) incluem também a Casa da Agricultura e a Polícia Florestal; mas estes não tiveram participação efetiva na microbacia estudada. As demais instituições (sem negrito) caracterizam-se pela pouca expressividade na cooperação junto aos produtores rurais daquela microbacia (em diferentes níveis): Casa da Agricultura, Sindicato Rural, Cooperativa dos Fornecedores de Cana, Universidade, Instituições de Crédito, Instituições de Saúde, CODASP, CESP, SAAE, CPFL. Além destes, não foram trabalhadas relações com a comunidade local, o mercado ou políticas públicas. No entanto, em termos de desenvolvimento rural, seriam esses os ambientes estratégicos na representação e facilitação das açōes pró-interesses dos proprietários. Não por acaso, os que mais poderiam ser beneficiados por tal cooperação são os proprietários que se encontram mais descapitalizados, desinformados e com poucas perspectivas de continuidade na terra.

A figura 19, ressalta assim, as opções do Consórcio em termos de parcerias para a operacionalização do programa:

- Poder de organização e persuasão (mudança no querer)

DEPRN, Promotoria e Associação dos Fornecedores de Cana.

- Estrutura básica para efetivar os plantios (mudança no poder) Fundação Florestal, CESP e Prefeitura.

- Comunicação (mudança no saber)

O próprio Consórcio, além do apoio do DEPRN, CESP, e Promotoria. 


\section{Conclusões}

Não se trata, aqui, de idealizar a participaçăo daquelas instituiçóes que năo fizeram parte do programa, mas de colocar em debate (já tardiamente) o esvaziamento, a omissão, e a dificuldade de trabalho integrado de instituiçбes públicas que năo estảo atuando efetivamente pelo interesse público (por não querer, saber, poder?), abrindo a possibilidade de açoes oportunistas, superticiais e simplistas, amparadas por lei, que se revestem de poder de autoridade para enfrentar um problema complexo, da qual elas nem sequer compreendem bem. Isso explica perfeitamente as poucas pretensరes (na época) do programa do Consórcio, que canaliza esforços para plantar árvores, sem levantar qualquer discussão sobre o campo da responsabilidade, mais complexo e potencialmente desmascarador de um sistema autoritário apoiado em conhecimentos científicos de baixa qualidade.

Embora tenha adotado o termo "proprietários rurais" durante todo o trabalho, isto não deve ser entendido como crença do autor em uma possível homogeneidade categórica. Pelo contrário, tentei demonstrar a grande heterogeneidade de condiçóes de vida, conhecimentos e interesses nessa unidade de trabalho cada vez mais valorizada que é a microbacia hidrográfica.

Por trás do termo se escondem grandes diferenças sociais, de renda, de oportunidades, de poderes... não permitindo, também em termos de reflorestamentos ciliares, uma única leitura da natureza da ação que deva ser desenvolvida, em cada contexto.

Em uma realidade histórica rural tão claramente excludente como a nossa, este estudo teve, sim, a pretensão de questionar um programa que a amplifica (gerando prestígio e privilégios para os executores do Programa e alguns poucos proprietários rurais, e ônus para a grande maioria), fornecendo subsídios para que os idealizadores e executores de tais programas refitam sobre a adequação de uma estrutura dialógica de ação, frente à natureza complexa da questão ambiental. Esta exige muito mais empenho do que 
simplesmente plantar árvores ou colocar programas como este em debate. Em qualquer área de conhecimento ou classe social, nossa ação deve fortalecer a criticidade das pessoas, sua capacidade de leitura dos contextos, seu prazer na conservação de sua cultura (em construção), sua participação política local e regional. Há que se levar em conta, porém, que esta é uma opção política, entre outras, como enfatiza Carvalho (1992: p. 1085): "A escolha pela concepção de educação que deve orientar a prática educativa é sobretudo, uma decisão política".

Diante das análises aqui desenvolvidas, que colocam frente a frente o planejamento de uma instituição que representa os interesses do governo de vários municípios consorciados e a avaliação e leituras dos proprietários rurais, pode-se concluir que:

- A estrutura de ação proposta pelo Consórcio na microbacia do ribeirão Forquilha adequou-se aos interesses do próprio Consórcio e de suas parcerias, em detrimento da maioria dos proprietários rurais. No limite, isto significou que os proprietários desta microbacia (que vem produzindo água de boa qualidade) foram punidos em função de uma potencial degradação do ribeirão Forquilha, ao invés de serem (por tal fato) premiados com um programa integrado, quando seriam parceiros fundamentais;

- A diversidade de interesses, condições de vida e leituras dos proprietários quanto ao seu meio demonstraram a inadequação de uma proposta padrão, de baixo custo e de curto prazo. Perdeu-se uma oportunidade de construção de uma ação sustentável, comprometida, responsável e de efeitos multiplicadores positivos entre os proprietários rurais da região, contribuindo para tanto a ausência das premissas básicas do diálogo, necessárias para todo e qualquer trabalho educacional; 
- programa não contribuiu para resgatar, junto aos agricultores, o papel das instituições potencialmente relacionados à conservação dos recursos hídricos no município de Capivari (como a Casa da Agricultura, SAAE, Prefeitura, Fundação Florestal, DEPRN, Sindicato Rural, CESP, usinas), perdendo a oportunidade de criar canais de comunicação entre eles (instituições e proprietários rurais);

- A estrutura de ação do programa (coerção para a adesão aos procedimentos planejados pelo Consórcio) desprezou e combateu as opiniões divergentes, deixando de abrir canal de contribuição importante ao avanço da pesquisa em reflorestamentos ciliares;

- Há indicações de que o medo (de novas intervenções da promotoria, a partir de denúncias de vizinhos ou órgãos fiscalizadores), gerado em tal programa, tenha aumentado a preocupação dos proprietários com a boa manutenção das espécies arbóreas das matas ciliares, sem contudo gerar responsabilidade sobre estas.

O conhecimento utilizado pela equipe do programa, nas comunicações com os proprietários (em busca do "convencimento") foi de qualidade questionável, ora em termos científicos, ora políticos, ora ideológicos, ora éticos, principalmente em relação:

- À leitura da realidade ambiental da microbacia, diferente da realidade geral das bacias dos rios Piracicaba e Capivari (degradados, principalmente, em função das altas taxas de urbanização e industrialização), motivo maior da existência do Consórcio;

- À estrutura coercitiva de um programa, pela qual se optou, voltado ao resgate/manutenção da qualidade ambiental;

- Ao significado das contribuições hidrológicas das matas ciliares no contexto maior do uso ocupação do solo, na microbacia; 
- À adaptação dos modelos de revegetação à realidade da microbacia.

A baixa qualidade do processo comunicativo que se estabeleceu no programa, obstruiu o afloramento de críticas e sugestöes (dentro dos quatro aspectos citados), que poderiam ser aproveitadas no aperfeiçoamento deste ou de outros programas de reflorestamento ciliar. Isso contribuiu para a apatia, antipatia e até revolta entre os proprietários.

A revegetação de matas ciliares não deve se constituir como política isolada, principalmente num contexto de resistência dos proprietários a essa ação. Enquanto as matas ciliares estiverem em propriedades de características variadas, sob a administração de proprietários com interesses também variados, programas integrados que os enxergue como potenciais zeladores da qualidade ambiental (ao invés de potenciais degradadores) devem ser priorizados.

São necessários maiores estudos quanto à qualidade dos plantios (viveiros, sanidade das mudas, qualidade genética para a sustentabilidade dos plantios, adequação das espécies à região, adequação das espécies aos diferentes tipos de solo onde foram plantadas, entre outros). As informações aqui apresentadas ainda são insuficientes para o julgamento do valor ambiental das ações desenvolvidas pelo Consórcio em seu programa de reflorestamento ciliar. 


\section{Anexo A}

\section{Histórico}

\section{Ha) das familias e propriedades dos entrevistados}

\section{Estevāo}

Está em Capivari desde 62. Comprou a terra e veio. É da região. Desde pequeno trabalha de terceiro na lavoura, com a familia.

Não há motivo especial pra escolha da propriedade: "deu certo de achar aqui. É o que tinha". Completa porém, dizendo que "tinha que ter água; valorizava mais a propriedade. Água pra trabalhar, pra criação." Compraram em conjunto com a família, Está em Capivari desde 62. Comprou a terra e veio. É da região. Desde pequeno senão não dava.

\section{Joaquim e Carlos}

Nasceram em Capivari. Estão na propriedade a 55 anos (terra comprada em 42). "Era tudo mata". A usina União São Paulo teria derrubado a maior parte dessa mata.

Herdaram a propriedade (hoje dividida entre 3 imãos). Faziam também trabalho de 'terceiro' em outras propriedades (1/3 da renda).

A água foi fator importante pra compra da terra, mas dizem que era muito comum a pequena propriedade ter água (é planejado pra ter água já na divisão da terra, senão é muito dificil de se vender).

Sobre o uso da área à beira dos córregos, eles dizem que sempre aproveitaram toda a área da propriedade: "aproveitava tudo, desde o tempo que não era ilegal. (Esse terreno correspondente à faixa ciliar) era bom pra pasto. $O$ pasto vai melhor (ai), pra gado. É bom pra arroz, mas ninguém planta".

\section{Cláudio}

Avós vieram da Suiça, compraram a terra há \pm 120 anos. Seu pai estaria hoje com 100 anos. A propriedade foi passando de pai pra filho. Atualmente a terra está dividida entre 4 proprietários, correspondendo às partes do pai e tios. $O$ tio já está no bairro a 65 anos. Avô era credor de um amigo, que era o antigo dono do sítio. A dívida então foi trocada pela terra. "(Na época da compra) era tudo mato, embaixo (a sede atual fica bem no vale), abandonado. Já tinha café.

Contam que não tinham dinheiro pra pagar o serviço de trator de esteira (que era de particular) pra tirar a vegetação, pra poder fazer os plantios; usavam então o trator comum.

Foi praticamente criado pelo tio. Conta que na juventude, pra namorar tinha que ir de bicicleta (e era longe); mas se trabalhasse na derrubada da capoeira com o trator, podia usá-lo depois.

Sua área, no vale, possui porção razoável de mata ciliar natural densa, e uma parte mais rala de regeneração natural, que vi pessoalmente.

\section{Mateus e Gustavo}


Terra comprada pelo avô da Alemanha, a mais de 100 anos, quando trabalhava com a cultura do café.

\section{José e Ana}

"Nasci aqui a 68 anos. Foi meu avô quem comprou a terra". Era uma divida que foi convertida em propriedade rural.

São 12 alq que foram divididos entre 4 proprietários (herança), 3 alq pra cada. A dele tem 2 águas.

Antes ele tinha bastante pasto e de 30 a $\mathbf{5 0 \%}$ de mata. No lugar de barroca ele não 'bulia', mas onde dava eles usavam, com lavoura ou criação. Semeou pasto.

\section{Leonardo}

O pai comprou em 37 , mudaram em 40 . Era tudo a lenha.

\section{Lucas}

Está na terra desde 63, quando pai ( que era corretor) comprou, sem nenhum motivo especial. Veio com 16, 17 anos pra cá.

\section{Thais}

Propriedade do avô, tem mais de 100 anos. Era uma propriedade muito grande: 2000 alq. Quando os avós morrem, a fazenda é vendida e ficam só com 500 alq., administrados por pai e tio, e posteriormente pelas irmãs: ela de um lado (sozinha) e outras duas no outro lado (do ribeirão). Antes era gado, café e cana. Tinha um engenho de açucar e alambique. Desativou-se o engenho e ficaram só com o café. Mais tarde o primo passou a tomar conta de tudo (pai de Cristina), por volta de 1946, quando começou a cana em Capivari. Era tudo gado. Hoje é um monopólio.

Passou a infância aqui, foi estudar em Piracicaba, voltou de lá casada.

\section{Luís}

Mudou pra propriedade em 43, quando o pai comprou a terra. Sem motivo especial pra escolha da área.

\section{Raquel}

Presidente da Associação dos fomecedores de cana de Capivari e produtora rural Em 02/03/1889 a propriedade é comprada pelo bisavô (dizem que já era de parente). 0 casarão tem 150 anos. Ele comprou área que pudesse ver, esse era o limite. Atividade na época era gado, produção de açúcar mascavo em pequeno engenho, tinha moinho de fazer fubá. Seu avô já era menos dinâmico. O pai foi agrônomo, formado em 46 na ESALQ. Conta que o pai se preocupava muito com aspectos sociais, por exemplo não queria construir uma piscina pra familia enquanto os funcionários não tivessem água encanada em suas casas, dentro da fazenda. Embora fizesse bem a conservação dos solos, calcareando, com curvas de nivel, conservando a mata, acha que ele não tinha muita visão de meio ambiente.

Bisavós falecem em 43. Ela foi morar em Capivari, onde cursou o primário. Estudou depois em Piracicaba, e voltou à propriedade em 85 para administrá-la. Aproveitou a infância na fazenda. Tem mata virgem de 13 alq na fazenda, conservada até hoje. Os caminhoneiros gostavam de entrar lá pra tirar pau pra 'fuero' (pau encaixado na carreta 
pra escorar a carga da cana). Ela proibiu e por alguns anos passou a usar eucalipto. Hoje tira uma ou outra árvore nativa pra muda.

\section{Pedro}

Encarregado de tratos culturais da Indústria Açucar São Francisco (IASF), nesse cargo desde 1982.

A usina se instalou em 1948. Na época só tinha cana própria. De lá pra cá veio aumentando o número de fornecedores e áreas arrendadas.

\section{Hb) Histórico da microbacia do ribeirão Forquilha}

\section{Estevão}

"A 30 anos atrás era fraca de lavoura. Era mais pasto. Não foi desmatado nada na região; só eucalipto, que planta e corta."

"Ribeirão era como hoje. Fizeram represa. Não tinha tanque nenhum." Hoje tem mais de 50 tanques na microbacia, "pra lavoura ou pro gado."

"Tinha mais bicho na época." Não gostavam de pescar nem caçar; ele não gosta muito de peixe. Diz que não pegavam nada na mata, e que na verdade era capoeira. Diz que o solo da região está mais ou menos tudo igual: ruim pra uns, igual pra outros. Existe muita diferença de solo. Ele considera que sua propriedade está em área não tão boa: "produzem até o dobro (que ele) na bacia".

As causa das mudanças que ele observa, estariam associadas ao "clima, produtos da cana, herbicidas. Tem produto... inseticida, que tem que ficar 5 anos sem plantar lavoura; resseca a terra."

Sobre a expansão das atividades até a beira do ribeirão, explica a facilidade do pasto na beira do rio pro gado beber água: "mais custo pra fazer bebedor longe. Lavoura é melhor na beira do ribeirão, é mais fresco, e terra na baixada é mais boa."

Observa que "hoje tem bastante garça, ave, por causa da represa. Muita pomba também. Não uso, não caço. Não como."

$\mathrm{Na}$ região (que ele conhece por ter nascido e sido criado nela, é também de andar por ai), diz que a história "é tudo igual" a deles ali.

Escolas: "A prefeitura pega de ônibus e leva pra usina São Francisco, pra aula. A prefeitura que paga. Era boa a escola perto. Agora piorou."

Seus filhos estudaram nessa antiga escola. Sua esposa é merendeira. Agora já faz um ano que fechou.

Postos de saúde e armazéns, só na cidade. Não há igrejas no bairro.

Histórico da qualidade do solo

"Piorou. Na época chovia mais. O que plantava dava. Menos pragas. Veio caindo a produtividade, mas erosão não aumentou." Acha que terra vem "cansando pelo clima". Eles fazem curva de nivel, procuram não deixar "correr água na área. Todos fazem no trator; ninguém faz no burro. Aluga máquina."

\section{Joaquim e Carlos}


Estão na propriedade a 55 anos (terra comprada em 42). "Era tudo mata". A usina União São Paulo teria derrubado a maior parte dessa mata.

O ribeirão Forquilha "sempre foi assim. Na seca diminui, na chuva volta. Nenhuma alteração".

A água foi fator importante pra compra da terra, mas dizem que era muito comum a pequena propriedade ter água (é planejado pra ter água já na divisão da terra, senão é muito difícil de se vender).

Costumavam pescar, mas gostavam de ir a outros lugares, onde tinha mais peixe. "Hoje tem muito tanque; tem mais peixe que antes".

"Na época já não tinha mata"; os 9 alqueires de mata que existiam já haviam sido demubados antes. Em uma das propriedades, existe uma área antiga de regeneração natural de 1 alq.

"Já não tinha mata quando a gente mudou (pra cá). Só a da fazenda (vizinha) que a usina União Sảo Paulo (USP) desmatou. Foram \pm 200 alq". Dizem que no começo era algodão, milho e batata.

Em 51, 52, chegou a cana e tomou conta de tudo, porque a cana dava mais retomo.

Pássaros foi o que mais desapareceu daquela época. Ele mesmo cria papa-capim que cai do ninho, pra depois soltar. Diz que os pais (do passarinho) vêm na gaiola, aberta, cuidar.

Os tanques que existem hoje ao longo do ribeirão foram feitos a uns 15, 17 anos.

"A 25 anos, a madeira vinha da matinha. Só pau seco. Depois que começaram a proibir, usa só gás. Antes era só (fogão) à lenha, a casa."

Histórico da qualidade do solo

Está pior hoje; veio cansando, são quase 50 anos de uso sem parar. O rendimento (produtividade) fica igual, por causa do calcário que ajuda o adubo a ter 'mais efeito'; mas a terra vai ficando mais fraca.

Erosão não tem, porque a qualidade da terra ajuda; é 'mais barrenta'.

"Todos fazem curva de nivel. É boa a conservação. USP é quem faz melhor."

Cláudio, complementado pela participação do tio, Roberto

A região foi ocupada por migrantes da Itália, Alemanha e Suiça.

O nome do ribeiräo vem de seu formato, em forquilha. "Dizem que (antigamente) chovia mais e tinha mais água: 'em janeiro, onde chove dorme, e onde almoça choverá', porque não dava pra voltar pro jantar. A água foi diminuindo (por causa do clima). Foi sujando, capim vai soterrando, fechando.

"(Na época da compra) era tudo mato, embaixo (a sede atual fica bem no vale), abandonado. Já tinha café.

"De 65 pra cá, era cerrado; já não era mata: 10\% era barbatimão (que era muito usado na época no cortume de couro); tinha pau-d'óleo, ingá, aroeira." De 35 anos pra cá, tiveram que tirar mata pra fazer lavoura, mas dizem que a maior parte dela já havia sido retirada anteriormente.

Os bichos sumiram e os peixes aumentaram, por causa dos tanques. "Hoje tem muita capivara que atrapalha. Tinha veado, paca, nhambú, oncinha, lobo guará, tamanduá, cachorro-do-mato. Tem até hoje cachorro-do-mato, gato-do-mato. Não é raro o gatodo-mato atacar suas galinhas. 
"Antes (o solo) era mais forte, nāo usava adubo (anos posteriores à retirada da vegetação natural). Hoje melhorou, com adubo, máquina. (Essa terra que veio enfraquecendo) chama 'terra de campo', não é boa pra planta, é acido. Se trabalhar ela, fica boa: calcário, aração..."

Mata ciliar, diz que só ficoụ em "luggar que não dava pra lavoura ou criaçăo", Como desce adubo da lavoura e é local mais úmido, segundo ele, ai vem um "capim bom". $\mathrm{Na}$ visão deles, o volume da represa vem diminuindo muito, "terra descendo e capim crescendo", fechando o espelho. As curvas sãa em desnivel, jogam a água no coletor e "vai carreando terra, soterrando as curvas e o açude". Dizem que a represa é da década de 60.

Entende que as causa dessas mudanças na microbacia estão diretamente associadas à lavoura e à criação (animais e pastos). "Bicho sumiu porque acabou as matas."

Diz que na "regiaăo de Capivari foi tudo assim", o mesmo processso das mudanças.

Disse que a análise de amostra de água da represa, feita a pouco tempo, acusou a presença de BHC.

Começou em 64, 65. Tinham 8 usinas na região que foram fechando de lá pra cá. Comentou sobre o problema do desemprego que virá com o corte mecânico da cana e questionou as justificativas ambientais dessa ação: "cana polui muito menos que fábrica. O fogo favorece $100 \%$ a lavoura", explicando que eles năo poderiam deixar de queimá-la.

Antigamente era por cotass e "a gente passava apertado": tinham cota de $\mathbf{5 0 0}$ ton, mas produziram 800; no outro ano ampliaram a cota pra 600 ton, mas produziram 1300. Tinham que se virar pra vender o que excedia a cota; às vezes até tinham que vender pra amigos que não completavam as próprias cotas, embora isso fosse proibido. Nessa época era mais açúcar que era produzido. Depois com o PROALCOOL, as usinas passaram a disputar a cana entre si.

Histórico da qualidade do solo

Quanto aos solos, eles trabalham sempre em nivel, e não exisțe processo erosivo.

\section{Mateus e Gustavo}

Quando o avô comprou a terra, a mais de 100 anos, trabalhava com a cultura do café. Dișseram que o ribeirão sempre foi asșim. "Desmatado, só na Cristina",

"Nos ribeirọes tinham peixes, mas nos tanques tem mais hoje".

Da mata só se usava lenha a muito tempo atrás. Eles mesmos nunca usaram. $\mathrm{Na}$ propriedade só usam "madeira serrada" (beneficiada). Da mata consumiam também jaboticaboba, pitanga (que tem até hoje) e ingá.

Muitos animais sumiram como o sagui. "Passarinhos sumiram bastante: jacú, azulāo, cựió, pintașșilgo.

Os solos deles "sempre foram \pm assim. Cana não estraga terreno: tudo em nível, (nossa) terra é vermelha". Falam da importância das raízes da cana pra conservação do solo.

Disseram que a vegetação nativa e matas ciliares não diminuíram desde que estão ali: "desmatamento é de 60 anos pra trás." Também não vêem nenhuma alteração nos córregos e repreșa: "não muda, não diminui," Apenas que o capim (imbiri) vem fechando pelas bordas, mas a cada 10 anos a represa (que dizem ser sido construida entre 70 e 72) é limpa. 
Atribuem as mudanças ecológicas ao desenvolvimento das lavouras, $1^{\circ}$ de café e banana, $2^{\circ}$ do algodẫo e $3^{\circ}$ da cana.

A ocupação até a beira dos ribeirões já tinha se dado a mais de 60 anos.

A conservação dos solos é feita pela usina, através dos terraços. Nas áreas dela (ușina) sạo em desnível e a água é "solta na mata"(fuṇção de coletoror). Agora querem fazer nas propriedades, mas "é dificuldade fazer nos sitios: soltar no vizinho nāo pode"; num sítio como o deles que é estreito e comprido (acompanhando o declive, até o vale) fica difícil ter coletores dentro da área.

A história da região "é tudo mais ou menos igual".

"Tinham escolas. Em 45 a professora ia de trole; a usina União São Paulo era de um francês." Quanto à infra-estrutura geral, "tudo em Capivari."

"Em 47 não podia queimar cana, até década de 60 (não tem certeza), quando era o tempo dos franceses (da usina Uniāo São Paulo)."

Não concordam com o que se coloca de demubadas de matạ: "Aqụi nạ̃o! Só quando tinha fogāo à lenhal"

Teve uma época, no passado, em que as máquinas que faziam o transporte de cana, ou eram de caldeira (a lenha, soltando fagulhas perigosas à cana, e não raro causando incêndios) ou à óleo. Conta caso em que um amigo nạo controlou o próprio fogo e quis enganar usina alegando que tinha sida a máquina. Pro azar dele, justo naquele dia do incêndio, a máquina que fazia a região era a movida à óleo...

Histónicico da qualidade do solo

Na propriedade o solo é bom, não tem erosão; segundo eles, ela ocorre mais em solo de areia.

\section{José e Ana}

No século passado (tempo do avô) era café, mas șó no (terreno) alto, por causa das geadas. Depois vieram algodão, batata e cebola. Então sai o algodạo pra entrar o milho, até que chega a cana, que está até hoje.

Tinha monjolo e moinho de fubá, muitos tanques já naquela época. Mas foram sendo soterrados (devido à erosão), porque aravam até perto da ágụa; na época não faziam curva de nivel, é coisa recente na microbacia; de 3 anos pra cá que se faz bem feita a conservação. Diz que a terra deles mesmo tem pouca erosão; era a usina quem tinha mais. Hoje existem muitos tanques de novo.

"Tinha muito bicho antes: veado, paca, macacọ, serelepe, sagụi, quati, cachorro-domato. Hoje tem outros: capivara, ratão do brejo, garça, passarinhos à beira do tanque (por causa dos peixes). "Com o reflorestamento, de 5 anos pra cá, vem aumentando os bichos".

"O solo veio enfraquecendo. Melhorou pelo trator e calcário. A produtividade vem caindo e capim (de ocorrência natural) vem mudando (conforme o solo vai mudando de acidez). O (capim) 'favorito' fica no mais ácido, e hoje não (tem) mais".

"Antes tinha muito olho d'água próximo às casas, que eram muitas. Hoje tudo secou, acho que entupiu."

De 68 pra cá não tem observado nada de diferente na represa (que abastece Capivari). Eles associam as mudanças em relação aos bichos à "cana, desmatação, veneno. Os passarinhos (de antes) sumiram tudo. Comiam cereais". 
"A história daqui é a mesma coișa da regiāo. A história do reflorestamento é só daqui". "O que segurou o pessọal... (foi que) em 85 chegou eletricidade. O gás chegou na década de 60".

Implantou o projetoto. Algumas morreram com geada e ele replantou pọ conta.

Histónico da qualidade do solo

"(A cultura da) cana traz muita acidez. Se for só a cana, vai diminuindo a fertilidade (do solo). Vai acabando". Adubar 2 vezes seria bom, mas o preço não compensa; então faz uma só e usa calcárió". O calcário custa hoje algo em tomo de R\$ 10/ton, na regiāo.

\section{Leonardo}

Tinha passarinho na época. Hoje tem mais. Quando se parou de usar veneno (na lavoura) veio vindo outros passarinhos: pomba do mato. Não tinha garça, pato d'água. O pai comprou em 37 , mudaram em 40 . Era tudo a lenha.

Mụdoụ com 7 anos, era mata virgem. Tinha pavạo, veado, cachorro-do-mato, coelho, gambá.

A pesca aumentou com o tanque; não tinha na propriedade deles, poị nạo tinham água.

A terra dele continua boa. Melhor que antigamente.

Antigamente, na época do pai, era tudo mata virgem. A avó de Cristina vendeu terreno e a mata, 'em pé'. No plano aravam, na barroca plantavam com cavadeira; não compensava. Dai transformaram tudo em pasto.

\section{Lucas}

Não existia ainda a represa em sua propriedade. No começo era pequena e depois ampliou pra irrigar a lavoura.

Tinha menos água (em termos gerais) no passado. "Com o represamento aumentontou mais ( a água); nascentes e poços não secam mais. Manteve a umidade".

Não tinha muito peixe, "só miudeza. Lá embaixo aumentou peixe com a represa (da Cristina)".

Hoje tem até mais bicho que antes, como a capivara. Veado tem ainda, ele afima, com base nos rastros que vê nas estradas. Acha que tem mais passarinho. Nhambụ sưmiụ, talvez por causa da queima da cana.

Os solos (ao menos em sua propriedade) melhoraram com a adubação, esterco, adubação verde (uso da crotalária, com sementes fornecidas pela cooperativa).

A conservação dos solos na região veio melhorando. Os terraços săo recentes, de 4 anos pra cá, graças ao trabalho da usina. Nesse trabalho estão por exemplo os incentivos da cooperativa: técnicos à disposição, 'tiram o nivel' de graça, medem a terra (na Cooperativa não pagam nada; a Associação desconta direto da usina);

Sobre a vegetação nativa, "essa que tem sempre teve. O eucalipto (talhão, que está dentro da faixa ciliar dos $30 \mathrm{~m}$ ), já tava ai e nunca foi cortado. A capoeira (dessa mesma área) jạ tinha. Mata ciliar "já praticamente não tinha". Não sabe dizer como ou quando se começou a usar a área de preservação permanente (APP) da mata ciliar, "o que usa hoje já usava".

"Aqui na região é tudo \pm a mesma história, muita mudança de lá (do passado) pra cá".

\section{Thaís}


Surgiram problemas de água em Capivari, o prefeito veio e negociou a construção da represa. Era ótima idéia, porque eles dali poderiam usar. O vale era era bem fundo (o chamado 'poçảo'). Era um rio de tamanho razoável. Hoje acha muito mais bonito, mais limpo. Eles não deixam pescar.

Antes da represa pescavam muito e caçavam. "Tinha muita codorna e perdiz; os tios vinham caçar aqui (na fazenda). Os cachorros iam no capim (onde elas 'criavam')". Com a queima da cana, esses ninhos foram sendo destruídos e a população diminuiu. Dizem que tem muita paca hoje estragando a roça. Ultimamente vem aparecendo papagaios, que ela nunca mais tinha visto desde 46 (a área da sede é muito bem arborizada).

Sobre as matas acha que nada mudou. "Na beira (da represa) continua igual, não mudou". Apesar disso, diz que não existia mata ciliar, era uma capoeira mais baixa.

Sobre os córregos e represa, não sabe dizer.

Segundo ela, o ponto de captação de água da represa é muito alto; como Cristina usa água da represa em seus pivôs, na seca existe o perigo de faltar água pra Capivari. Essa captação não pôde ser mais baixa por que senão não teria desnível suficiente pra mandá-la a Capivari (por gravidade). Por outro lado escuta falar de desperdício dessa água em Capivari por incapacidade de tratamento.

Acredita que entre as causas das mudanças estão a própria represa e a cana (principalmente devido à queima).

Sobre a conservação dos solos, conta que "não se faziam terraços, e hoje ninguém mais planta sem terraço". Acredita que os solos foram melhorando com o manejo: "erosão diminuiu muito com o manejo".

Propriedade do avô, tem mais de 100 anos. Era uma propriedade muito grande: 2000 alq. Quando os avós morrem, a fazenda é vendida e ficam só com 500 alq., administrados por pai e tio, e posteriormente pelas irmãs: ela de um lado (sozinha) e outras duas no outro lado (do ribeirão). Antes era gado, café e cana. Tinha um engenho de açúcar e alambique. Desativou-se o engenho e ficaram só com o café. Mais tarde o primo passou a tomar conta de tudo (pai de Cristina), por volta de 1946, quando começou a cana em Capivari. Era tudo gado. Hoje é um monopólio.

\section{Luís}

Está a mesma coisa, do passado pra hoje. Ouviu falar que o eucalipto diminuiu a água na bacia.

Antes se pescava e caçava mais que hoje. Ele mesmo é contra a caça e não gosta de pescar. Usavam plantas medicinais da mata antigamente.

Antes tinha veado, paca, capivara (poucas), pássaro preto, canário, azulão. Hoje tem muita capivara, por causa da proibição. Ouviu falar que tem tamanduá por aí; bugio ele próprio já viu.

Os solos melhoraram por causa do trator. Na propriedade dele reduziu erosão.

A luz (energia elétrica) chegou por aqui a uns 20 anos, e gás já faz tempo, quando revezavam entre ele e o fogão a lenha. De 5 anos pra cá, parou de vez com a lenha. "Essa lenha catava daqui". A uns 20 anos atrás tirou \pm 8 alq de mata pra fazer lavoura (cana e milho). Não vendeu; enleirou e queimou. Não conhecia lei alguma que proibisse cortar.

A água aumentou por causa dos tanques; as nascentes estão do mesmo jeito de sempre.

Em geral a história dessa região toda é igual à deles ali. 
Raquel e Maria; sua mãe

Q ribeirão Forquilha era um córrego pequeno, e onde hoje é a represa era um alargamento natural com um redemoinho, que tomava perigoso o banho. $\mathrm{Na}$ microbacia tinha muito mais volume de água do que hoje, por causa do grande número de tanques que foram construidos. As nascentes não mudaram em nada, quando chove muito nasce água de todo lado.

$\mathrm{Na}$ infância costumava caçar passarinho e rolinha. Os tios vinham em grupos pra caçar veado, paca, perdiz.

Alguns produtos da mata eram utilizados pelos 'raizeiros', os curandeiros da fazenda, cuja tradição continua até hoje através das benzedeiras (que já medicaram inclusive os filhos da proprietária). Por volta de 46 tiraram cerca de 4 a 5 alq de mata pra implantar pasto, no lote que até hoje chama 'matão'. Haviam áreas de 'quiçaça' (capoeira), uma delas tinha muito arranha-gato, lembra a mãe. Depois foi tirada e plantado cana.

Qs solos melhoraram muito, em suas qualidades. Quimicamente foi melhorando.

Tem muito mais peixes hoje que antes. A represa foi construída sem escada pros peixes, o que a proprietária tem brigado muito com a prefeitura. No tanque, que fica em parte em sua propriedade, é proibida a pesca à pessoas estranhas, sendo permitida aos funcionários: Sabe que tem lá traíra, saguirú, cascudo.

Sobre animais do mato e aves, hoje sabe que tem mais que antes: veadinho, codoma, seriema, nambú, perdiz, ratão e muita capivara. A capivara vem causando problemas nas cana e milho. "Destrói muito". Quriço tem muito. Raposinha, gambá, lagarto. Hoje tem muita garça e socó, que não tinha antes. Hoje tem muito quero-quero, muita pomba, muito gavião. A cobra sumiu muito; antes dos plantios nas matas ciliares queimavam todas as barrocas, pois era mais fácil que roçar, e assim não tinha muita cobra. Desde 91 começou a aumentar a cobra, muitas bravas, no meio da lavoura. Não registraram nenhum acidente.

As causas dessas mudanças no ambiente estariam associadas à expansão da cana (área anteriormente utilizada com pastagens), impulsionadas pelo PROALCOOL.

Com as pastagens, quando não havia ainda o maquinário, já se utilizava a beira dos córregos e ribeirões; grotas. Depois com a cana; entrou o maquinário pra ir arrumando o terreno, quando se faziam correçöes de erosōes, fechando-as.

Sobre a conservação de solos da região, antes só se faziam as curvas de nível. "Hoje tem mais terraço".

A história de ocupação de toda essa região é semelhante, desde 70 . Alguns se dedicando a hortifrutigranjeiros. Eles mesmos tinham café.

Em 02/03/1889 a propriedade é comprada pelo bisavô (dizem que já era de parente). O casarão tem 150 anos. Ele comprou área que pudesse ver, esse era o limite. Atividade na época era gado; produção de açúcar mascavo em pequeno engenho; tinha moinho de fazer fubá.

\section{Sobre a represa}

Foi inaugurada em 69. A área foi cedida, mas ainda é de propriedade dela. Prefeitura tem direito de uso, apenas. A dois anos atrás altos niveis de erosão com o cultivo do milho nas bordas da represa. Aí foi feito o acordo na beira da represa, com o Consórcio, de fazer linhas retas (pela dificuldade de acompanhar o contomo da represa), ora com mais, ora com menos de $30 \mathrm{~m}$. São 18 ha de espelho d'água em suas terras; e por volta de 20 ha de matas ciliares em seu entorno. 
Pedro, funcionário (encarregado de tratos culturais da Indústria Açúcar São Francisco (IASF, instalada em 1948), nesse cargo desde 1982.) (>30 anos)

A usina se instalou em 1948. Na época só tinha cana própria. De lá pra cá veio aumentando o número de fornecedores e áreas arrendadas.

Desde 1982, quando começou a trabalhar pela usina, não houve desmatamento na região. As áreas onde já existia mata natural na beira dos rios, em suas áreas, estão assim até hoje. Naturalmente já estavam lá.

Teve mudanças sim no solo, pra melhor. Em 90 mudou-se o sistema de conservação de solo usado pela usina: até 90 era tudo em nivel, e estourava. Daí começaram a fazer as curvas em desnivel, com coletores (onde plantaram capim ou a própria cana). $O$ que tem na região foi a usina quem fez.

Quanto aos bichos, nunca teve muito. Eram mais gato e cachorro do mato, além de cobras e lagartos, que tem até hoje. Também tem até hoje, embora não seja comum de ver: marrequinha, frango d'água, garça.

\section{Hc) Histórico dos plantios}

\section{Estevão \\ Início}

"Foi \pm em 94 quando (eu) soube que tavam plantando. O pessoal de Piracicaba nunca veio. Quem veio foi o [Antonio]. [Antonio] não era bem recebido, chegava com medo, se desculpando." Ele então não discutiu e aceitou. "(Antonio) disse que teria que plantar $30 \mathrm{~m}$. Acertou (a retirada das) mudas com prefeitura, e 2 funcionários pra plantar. Meu irmão, [omitido], trazia as mudas. Era obrigado a buscar as mudas lá." Como receberam esse programa? "Família não gostou. Estranharam. Todos revoltados no bairro". Não sabe sobre o envolvimento dos outros proprietários.

Papel do sindicato

"(Eles do Sindicato Rural e da Cooperativa) não (nos) procuraram, porque a gente é pequeno. Ficamo pra depois no projeto e por isso que tá atrasado. (A gente) fica sem saber; a informação é ruim. Não tem como se defender. Fórum só quer fudê nóis!"

Reuniões promovidas pelo programa

Não participou, de nenhuma. "Não fui chamado". Sabe como foi uma delas, na Cooperativa: "Osmar (Bresciani) disse que se era pra beneficiar a cidade, e se ( a água) é cobrada, a prefeitura deveria dar uma contribuição pra nós. A prefeitura deu mudas, que eu saiba".

Incentivos à reflexão/discussão/organização entre os proprietários

Não houve nenhum incentivo: "não. (Os proprietários) ficaram acuados esperando pra ver se ia chegar. $(\mathrm{Eu}) \mathrm{Nem}$ sabia que ia chegar até aqui. No início disseram que isso ia melhorar a água. Começaram na represa."

"Carlos disse que era bom pro ambiente. Era pro meio ambiente, pra melhorar a qualidade da água".

Sobre algum trabalho educativo, disse não ter havido. 
Termos assinados

Não lembra dos 'papéis', mas assinou. "Termo de comprometimento... não lembro. Era relativo à compromisso de plantar".

Relacionamento com a equipe do programa

"Nunca teve desavença nenhuma. Não conheço os de Piracicaba."

"Ficavam bravos quando o pessoal recusava (plantar)."

Atribuições da equipe e do proprietário

Equipe: "só a muda. Veio 2 funcionários pra plantar, pra separar a 'qualidade'."

"Mas o transporte das muda, cerca, manutenção, mão-de-obra, cova e preparo do solo, foi tudo nóis daqui".

Igualdade de regras para todos

Não sabe. Acredita que existam privilégios, "tem negociação, mas não posso afirmar. Acho que as parte dos mais pobre ficaram melhor que as dos mais ricos. 'Peixe grande' tem mais força, cuida menos. Tem advogado".

Não sabe porque está ainda com processo: "Mas tá tudo plantado!". Acha que é por causa da foto (os R\$1.200,00), "deve ser. Não tenho mais área". Ou talvez por causa de seus tanques, sem cobertura florestal em volta.

\section{Joaquim e Carlos}

Início

Joaquim ficou sabendo por vizinhos que o programa ('o plantio') ia chegar. Foi 'convocado' pra ir na Associação, sozinho, pra explicarem o que era o programa. Ele não foi contra. "Se não fosse preciso, o serviço era menor; a prefeitura veio e ajudou uma parte".

Recebeu o programa "sem problemas", apesar de que sua cana estava formada a apenas 1 ano. Mas foi dado um prazo pra que ele tirasse a cana.

Papel do sindicato

"Não participou."

Reuniōes promovidas pelo programa

Para seu irmão, Carlos, o início foi diferente: "No começo teve reunião na Cooperativa, todo mundo junto. Ninguém abriu a boca. Tudo que (o pessoal do programa) explicou, (a gente) saía e ficava 5\%. Foi falado (que o prazo pro plantio era de) 2 anos, senão era processado". Lembra que ocorreram 3 ou 4 reuniōes no total.

"(Eles do programa) disseram: 'é lei federal'; que podia melhorar a água. Que podia aumentar a quantidade de água". Ele diz que não percebeu aumento algum até agora.

Segundo um dos entrevistados, na reunião foi falado de uma "multa pesadíssima, a ponto até de ter que vender a terra".

Incentivos à reflexão/discussão/organização entre os proprietários

O que teve foi "a reunião; eram as explicações." Quando perguntei sobre o estímulo à discussão entre os proprietários, disse que não houve. Sobre a união entre os proprietários para discutir 0 assunto, na época, respondeu negativamente. 
Termos assinados

Não lembra bem dos nomes, mas assinou um documento se comprometendo, "e se não plantar, 'multa gravissima'. Assinei sozinho (quando do momento da assinatura, sem a presença de outros proprietários); já sabia que precisava concordar. "Eu procuro minha parte e cada um que se vire."

Relacionamento com a equipe do programa

"Nunca respondi e nunca vou responder", no sentido de brigar, discutir com o pessoal do programa. Acha que foi tudo "OK, bom. Aceitaram o pedido da cana."

\section{atribuições da equipe e do proprietário}

Equipe do programa: as mudas (para plantio e replantio), parte da mão-de-obra para o plantio, e o coveamento na primeira etapa de plantio.

Proprietário: o transporte das mudas, o preparo da terra, parte da mão-de-obra pro plantio (contratou duas moças a R\$ 10/dia, cada, ao longo de 4 dias, somando R\$ 80), manutenção e replantio.

Igualdade de regras para todos

"Foi igual pra todos."

\section{Cláudio}

Início

Sobre o início do programa, contam que foram visitados por 3 pessoas, que vieram pra uma vistoria em sua propriedade, logo no inicio do programa. As pessoas teriam observado irregularidades quanto às áreas de preservação permanente da propriedade. Pediram ao proprietário que 'assinasse a vistoria', ao que ele se recusou. Voltaram então outro dia com mais 2 pessoas que seriam testemunhas, e dispensariam sua assinatura, caso não mudasse de idéia; mas teriam que levá-lo algemado até Piracicaba, pra que assinasse lá, frente à autoridade policial. Aí então o proprietário pensou melhor e resolveu assinar. $O$ relacionamento nesse começo foi difícil, e frente à indignação do proprietário e à sua incapacidade de enfrentamento da lei ('federal'), um elemento da equipe do programa teria criado um clima irônico na comunicação com tal proprietário, o que seu sobrinho tentou contornar assumindo a representação do tio nesses assuntos, até hoje.

Contam ainda que em certa ocasião, num dos encontros entre a equipe e eles, na propriedade, a conversa foi gravada secretamente e depois apresentada numa audiência que eles (proprietários) tiveram com o promotor, comprometendo-os.

Esses dois episódios se divulgaram rapidamente entre os vizinhos e amigos, alguns dos quais lembraram de tais fatos durante as entrevistas.

A maioria dos proprietários foram colegas de escola, já se conhecem desde criança, a 60 anos. A informação correu e gerou medo.

Frente à não aceitação do programa, técnico disse: "não tem como conversar com você", e o ameaçou a ter que conversar com o promotor "caso não quisesse florestar". Houve uma promessa de campanha do prefeito, onde a prefeitura assumia alguns compromissos relativos aos plantios do programa; prefeitura acabou sendo processada pelo promotor. 
Reuniōes promovidas pelo programa

"Reunião com o promotor na Cooperativa, dizendo do código de 65,..."

Em certa ocasião soube que haveria uma reunião do programa na fazenda da proprietária onde está a represa. Não gostou da idéia, procurou a orientação do advogado, que não sabia de nada. Ficou indignado com o fato do próprio advogado da Cooperativa não saber de nada, e levantou algumas suspeitas de favorecimento da proprietária, em cuja propriedade tinham se iniciado os plantios. A reunião acabou sendo transferida para a Cooperativa.

"Por que não foi feita uma reunião de esclarecimento?" Questiona o papel do advogado que não cumpriu sua função, de estar a serviço dos cooperados.

Incentivos à reflexão/discussão/organização entre os proprietários

Não foi feito nenhum trabalho nesse sentido, mas afirma ter união suficiente entre eles pra que isso pudesse ter ocorrido.

Termos assinados

Assinou um 'contrato' onde tinham "as obrigaçōes, as combinações". Segundo ele, assinou apenas por que tinha a lei por trás. Trouxe o contrato pra me mostrar e leu o nome CESP: "será que a CESP não era o 'patrão'?"

relacionamento com a equipe do programa

Pediu à equipe se podia ser plantado banana, e a resposta foi negativa.

"Ronaldo (técnico da equipe) disse: 'Faz que fica bonito"; eu falei: "Faz você na sua terra que fica." O técnico disse ainda, segundo o proprietário: "Você sabe que essa terra não é sua?", ao que ele respondeu: "Engraçado... pra pagar imposto é minha." Fica muita irritado com essa questão da posse: "Vou plantar no que não é meu? Fazer manutenção no que não é meu?"

Desafiou Ronaldo a fazer uma reunião na Cooperativa, e com o advogado, para ver se tinha alguém que era a favor de fazer esse programa.

atribuições da equipe e do proprietário

Prefeitura deu mudas, ajudou com a mão-de-obra no plantio.

Eles (proprietários) prepararam o solo por conta própria.

Igualdade de regras para todos

Considera que o tratamento foi igual, mas os 'poderes' de cada um eram diferentes.

Quanto ao replantio explica as maiores dificuldades que teve: o plantio em área de brejo; o capim braquiária que "não deixa a muda vir"; e a saúva cortando as mudas. Reclama da burocracia pra comprar produto (isca inseticida) e pra usá-lo, porque "se o fiscal pega, processa".

Quanto ao plantio incompleto, isso se deveria ao rompimento de um acordo verbal por parte da equipe do programa, feito no inicio, garantindo que ele poderia deixar uma faixa de capim beirando seu tanque, pra caminho do gado. Depois mudou-se de idéia ao longo das vistorias, e hoje é exigido o plantio nessa faixa. Explica que primeiro tudo foi feito (os plantios), conforme o combinado. Dai sobrou muda e ele levou pra um outro sítio, pra ser plantada lá. Depois, o pessoal do programa voltou dizendo que tinha que plantar mais lá. 


\section{Mateus e Gustavo}

Inicio

"Começou com boatos. Reunião na Cooperativa. $1^{\circ}$ reunião: foi a [Ester] dizendo que era importante". Alguns foram contra, não teve entendimento e foram saindo. Ele mesmo diz que não era contra, "desde que voltasse um recurso. Quem só tinha gado ia perder tudo." Acham até que uma pessoa vendeu a propriedade por isso. "Eram até agressivos (os proprietários). Aqui (na propriedade) foi o primeiro (plantio) depois da [Raquel]. Na segunda reuniäo era obrigado (a aderir), com o promotor, dizendo que tinham multa pelo desmatamento que contava desde aquele tempo. Plantamos já no $1^{\circ}$ ano."

papel do sindicato

"O Sindicato Rural... hoje orientam em tudo; na época não tinham."

reuniőes promovidas pelo programa

"Foi falado (a respeito dos esclarecimentos sobre legislação e problemática ambiental). Os outros proprietários criticavam, rebatiam, comparando com outras regiöes. Dois pesos, duas medidas (pelo programa se restringir a eles apenas)." Comparou com a diferença da aposentadoria dos deputados e a questão do direito (justiça).

Incentivos à refiexåo/discussão/organização entre os proprietários

"Nas reuniōes foi explicado o processo de degradação, causa, efeito".

Termos assinados

"O papel foi assinado, mas nem foi lido. $O$ advogado (presente) era da cooperativa e falou: 'nem falem nada, peguem, assinem e pronto'. Explicou da multa retroativa."

relacionamento com a equipe do programa

"Sempre bom."

atribuiç̋̌es da equipe e do proprietário

equipe: mudas (dadas na cidade), prefeitura deu 4 ou 5 pessoas pro plantio, e um replantio foi feito com a ajuda da prefeitura e do Carlinhos;

Proprietários: alugaram caminhão (pra buscar as mudas), descarregaram; tiraram a cana, prepararam o terreno, ajudaram a plantar.

Igualdade de regras para todos

"Não foi. Alguns não obedeceram. Mas não dá pra dizer."

José e Ana

Inicio

"Vieram, tiraram fotografia, fizeram mapa. Chamou na cooperativa e lá, (deram) explicação que tinha que plantar. Disse (o palestrante) que o município já estava multado por desmatamento e que abateria a multa com esses plantios. (Disse que) tinha que tirar a cana (da faixa ciliar) mesmo que fosse $01^{\circ}$ ano (de idade da soqueira)".

reuniöes promovidas pelo programa 
Sim, participou. "Falaram que era pra não poluir a água, e pra aumentar a água. Mandaram fazer curva de nível. A água é toda levada pro ribeirão; em uma noite só, soterrou o tanque. Acontecia mesmo e foi bom terem falado: tem que fazer bem feito (os terraços, curvas de nível) senão é pior (do que se não tivesse)!"

"Pediram pra capinar. Sem ganhar nada! Tá estorvando e ainda tem que cuidar!"

"Deram 2 anos de prazo pra fazer. Em dois anos davam facilidades. Quem não fizesse era multado e faria por conta: viriam com máquina e o dono pagaria".

"Queriam que adubasse, por conta (do proprietário), ainda!".

Termos assinados

Assinou. "Era compromisso para plantar e cuidar. E eles (do programa) se comprometeram de dar as mudas. Prefeito prometeu (cuidar) mas não cumpriu".

relacionamento com a equipe do programa

"No começo vieram, depois não vieram mais".

O relacionamento "era bom, porque estava tudo certo".

atribuições da equipe e do proprietário

Equipe: mudas e 6 funcionários da prefeitura.

Proprietários: buscar a muda, ajuda no plantio, capina (coroamento) a cada 6 meses no 2 primeiros anos, até que as mudas tivessem uns $2 \mathrm{~m}$ de altura; replantio por conta própria (que foi feito com as sobras de mudas dos vizinhos).

Igualdade de regras para todos

Não sabe. Acha que trataram igual todo mundo.

Implantou o projeto. Algumas morreram com geada e ele replantou por conta.

Hoje só bezerro. Antes tinham cana, capim e gado. $O$ gado ajudava muito; todo ano vendiam bezerro, tinham leite, faziam queijo, vendiam gado. Trabalhavam na terra de um amigo, arrendando. Tinham um trato bom (representava uma boa receita pra ele). Aquele amigo perdeu terreno com as ánores; tinha um trator novo que não compensou, com o pouco terreno, e vendeu. Esse amigo preparava a cana dele também. Com a 'floresta' tudo mudou. Mudou o acordo (se desfez).

\section{Leonardo}

Inicio

Começou com uma reuniăo dizendo que todos tinham que plantar. Reunião na cooperativa, quando prefeitura disse que ia plantar. Começou do outro lado (Sustein, Cristina). Até chegar nele foram 2 anos. Então promotor processou. E eles mesmos tiveram que plantar. Deram as mudas e a família mesmo plantou.

Na vistoria inicial foi observado: "disposto a colaborar com o reflorestamento mas não possui mão-de-obra pra plantio. Devem ser usadas espécies adaptadas ao encharcamento do solo".

papel do sindicato

Não teve. 
reuniōes promovidas pelo programa

Ele mesmo não estava, mas sabe que teve, quando foi falado do compromisso da prefeitura.

Incentivos à reflexão/discussão/organização entre os proprietários

Não tomou conhecimento de nada do tipo.

Termos assinados

Assinou. "Era a responsabilidade de plantio. Demoraram tanto pra plantar que quando chegou não tinha... esgotou o prazo".

relacionamento com a equipe do programa

"[Antonio] levou ao conhecimento do promotor, que disse: 'isso ai não tem nada com a prefeitura. É você".

atribuições da equipe e do proprietário

prefeitura: deu muda e uma pessoa pra orientar o plantio.

Proprietário: plantou ele mesmo, teve que buscar a muda.

Igualdade de regras para todos

"Não foi. Prefeitura plantou do lado de lá e demorou. Os outros, do lado de lá, do começo, foram beneficiados".

\section{Lucas}

Inicio

"Houve convocação pra reunião". Esclareceram o que tinha que ser feito. Fizeram os contratos. "Durante a reunião avisaram que quem não fizesse o promotor iria processar. Era lei e era obrigatório".

Receberam o programa (a familia) normalmente; não acharam que ia prejudicar em nada.

papel do sindicato

Não atuou.

reuniōes promovidas pelo programa

"Disseram da bacia hidrográfica do Capivari e que aqui (Forquilha) afetava mais por ser (manancial de) abastecimento da cidade (de Capivari)".

Incentivos à reflexão/discussão/organização entre os proprietánios

Não teve. Só reunião esclarecendo. O estímulo às discussões teve na Associação, quando ouviram reclamações. Lembra que o pessoal não era do DEPRN.

Termos assinados

Assinou documento de compromisso, pra cuidar da área, das plantas.

relacionamento com a equipe do programa

"Sem problema nenhum. Falaram que ia dar peixe e não deram. Promessa de ser de graça, mas não veio". Ofereceram tilápia mas ele não quis. Queria tambaqui, pacu, 
carpa. Me disse que o custo está por volta de R\$ 0,30/peixe pequeno (diferente de alevino, que se compra por milheiro - grupos de 1000). Ele já colocou tucunaré nos tanques mas morreu. Tem "problemas de sistema de água pra tanque de peixe".

atribuições da equipe e do proprietánio

prefeitura: (fomeceu) as mudas e o pessoal pra plantar.

Proprietário: quem preparou a terra e buscou as mudas.

Igualdade de regras para todos

Sim, foi igual.

\section{Thaís}

Início

O pessoal do SAAE veio avisar que seria obrigatório. Assinaram o acordo (de abandono da exploração econômica) à medida em que fossem renovando os lotes (últimos cortes da cana antes da renovação).

papel do sindicato

Não teve.

reuniões promovidas pelo programa

Ela não participou. "Vieram aqui diversas vezes". Diz ter havido esclarecimento tanto sobre a legislação como sobre a problemática ambiental envolvida.

Incentivos à reflexão/discussão/organização entre os proprietários

Não existiram. "Na época houve muita resistência". Agora acha que todo mundo aceitou.

relacionamento com a equipe do programa

"Não teve mais. Só o Carlos vistoria".

atribuições da equipe e do proprietário

equipe: mudas

proprietária: plantio e o transporte das mudas.

Igualdade de regras para todos

"Foi igual. [Raquel] foi a que mais aderiu".

Segundo a proprietária, a largura da faixa de plantio adotada pelo programa na margem da represa, em sua propriedade foi de $30 \mathrm{~m}$.

\section{Luís}

Início

"Passou homem ai da Casa da Lavoura perguntando umas coisas ai, dizendo que ia mandar gente pra melhorar solo e água, que ia melhorar pra nóis. Depois, turma de Piracicaba, passaram em 4 e deixou carta, intimando pra ir no escritório em Piracicaba". Marcaram dia pra ver quando iam plantar árvore. O vizinho avisou da "turma da árvore" que ia passar em sua propriedade e convidou pra ir ver junto com ele: 'disse que é obrigado a plantar', avisou o vizinho. Este apresentou o proprietário, e 
deixaram com ele também uma intimação pra ir a Piracicaba também. Questionou: "por que tenho que ir, já que estou de acordo (com o plantio)?". Então não precisou ir. "Se é lei, e disse que tem que plantar, se a cooperativa disser que tem... por que ir lá?".

Ele foi sozinho na cooperativa, falou "com o advogado da cooperativa, que disse: 'vamos ver o que se pode fazer... De começo vamos concordar'. No outro dia chamou um por um, o chefão das árvore; se não tivesse de acordo tinha que ir atrás de advogado".

Na vistoria inicial, verificou-se que o proprietário queria mudas de eucalipto; uma das áreas fora prevista para enriquecimento.

reuniões promovidas pelo programa

"Na reunião, promotor tava lá, e pessoal perguntava bastante pra ele. O promotor disse que tava cumprindo a lei. Não lembra se o pessoal das árvores tavam. Teve uma reunião que eu não fui".

Termos assinados

"Assinei contrato que tava de acordo e deveria zelar, e que as mudas eles davam".

relacionamento com a equipe do programa

Foi bom. Disseram que seu nome até saiu no jomal, mas ele não viu.

atribuições da equipe e do proprietário

Equipe: mudas e mandaram pessoal da prefeitura que sabia plantar.

Ele: a terra, teve que buscar as mudas, preparar a terra, plantar junto com prefeitura e zelar. E se não cuidasse tinha que ir pro advogado; "o custo era menor topando".

Igualdade de regras para todos

"Igual pra todo mundo, mas os que não obedeceu, multaram. Eles não têm culpa, não são ruim. Eles avisaram várias vezes: se não der pra fazer, aí vai na cooperativa reclamar (eles queriam facilitar). Senão fizer, depois piora. As pessoas (que vinham) pra ver eram diferentes cada vez, de Piracicaba". E a favor de achar um acordo, sempre.

\section{Raquel, proprietária e presidente da Associação dos Fornecedores de Cana de Capivari \\ Início}

Ela assumiu que seria em sua propriedade o projeto pioneiro, quando aconteceu 0 lançamento do Consórcio em Capivari (acordo de cooperação com a Associação dos fornecedores de cana). Veio o presidente da CESP e estabeleceu convênio com a Associação. As mudas vieram de promissão. Depois, desenvolveram reuniões na associação. Por algum tempo só ela plantou, com o apoio da prefeitura, exigiu adubação (diz que é possível ver a diferença em campo). Encontrou alguma dificuldade devido ao entulho retirado da represa pela prefeitura, depositado às margens, onde deveriam ser feitos os plantios.

papel do sindicato

Não teve. 
reuniōes promovidas pelo programa

A primeira foi em março de 91; foram mais de uma. Ela participou de algumas. Inicialmente o trabalho foi direto com ela. Nessa época já haviam plantas grandes. Ela cedeu lugar na Associação; foi o modo do Consórcio se firmar, e queriam algo pra mostrar (como um ponto de encontro). Trouxeram o prefeito pra ver e ecologistas. Tiveram problema de tempo: áreas onde não deu tempo de eliminar corretamente o (capim) camerum; com mais tempo e planejamento teriam evitado, mas ninguém pode prever isso.

Incentivos à reflexão/discussão/organizaçăo entre os proprietários

"A crítica na época era: 'por que plantar essas porcarias? Se vai morrer?' ". Ela começou e disse aos proprietários que teriam chance de plantar depois.

Termos assinados

"Foram assinados em dia de campo com 250 agricultores; foi um ato grande aqui na fazenda." Não lembra bem dos termos.

relacionamento com a equipe do programa

Pessoal muito bom. As críticas ao pessoal da prefeitura uniram muito Sandra a ela: "o pessoal da prefeitura era muito bronco".

atribuiçőes da equipe e do proprietário

Evandro e Sandra sempre passavam, estavam bem envolvidos com o trabalho. Ela reconhece porém, que essa visita frequente se deva ao fato dela ser presidente da Associação.

Pedro

Inicio

Foram procurados por algum órgão (que ele não soube dizer qual) e foi pedido que se respeitasse aquela faixa, sendo proibido seu uso agrícola.

reuniões promovidas pelo programa

Ele mesmo não foi e não sabe se outro foi.

Incentivos à refiexão/discussão/organização entre os proprietánios

Acha que foram incentivados.

Termos assinados

Não assinou, não sabe.

relacionamento com a equipe do programa

"Bom, tranquilo".

atribuiçס̃es da equipe e do proprietário

Equipe: mudas, orientação para o plantio (diferentes variedades).

Eles: toda mão-de-obra (plantio, manutenção e replantio), buscaram as mudas. 
Responsabilidades da usina quanto aos plantios em áreas de fomecedores e arrendadas

Nas primeiras, a responsabilidade é toda do proprietário, embora a usina tenha muito cuidado nas queimadas. Nas segundas, a usina tem responsabilidade na conservação dos plantios. Em nenhuma delas se responsabiliza em plantar.

\section{Núcleos temáticos}

\section{Sobre as dificuldades enfrentadas e avaliaçōes sobre serviços/instituiçōes}

\section{1a) Maiores dificuldades}

José e Ana dizem que "O tempo não ajuda pra quem não tem irrigação. Depois do plano real não tem dado mais". Precisa de motores e bomba pra usar a própria água, mas o dinheiro vem diminuindo. Eles sentem muito a falta de telefone, por motivos de segurança como incêndios, inclusive), mas o telefone celular do plano da Cooperativa "não pega aqui pela altura (estão em lugar muito baixo, no vale)."

"O prefeito prometeu um telefone público, mas este não é muito útil, porque ninguém atende e não tem como as pessoas deixarem recado."

Banco do Brasil empresta pro pequeno agricultor a $12 \%$ ao ano. Pra ele o limite é de R\$5600,00. "Já caiu pra $9 \% "$ ". "O crédito é meio complicado; podia facilitar (todos os herdeiros precisam assinar, para a hipoteca exigida)."

Disse que pra cortar eucalipto, mesmo fora dos $30 \mathrm{~m}$, "tem que tirar ordem do IBAMA". Sobre os tanques, diz que: "Tanque em cima é mais difícil de parar água, daí gasta mais água, mais motor (a respeito da proibição de se fazer o tanque em seu próprio vale). Não causaria problema algum, sem poluição nenhuma (caso fosse feito no vale)".

"Não tem ajuda pra alevino; ninguém falou nada sobre ajuda". Na época tava $R \$ 100$ o milheiro, hoje tá $R \$ 120$.

"O cascudo faz buraco no tanque".

"Muito trabalho. Tem que trabalhar." Joaquim e Carlos moram na cidade hoje, e vem todo dia pra propriedade. Vivem da cana, apesar de ter preço baixo, segundo eles. "Outras como o tomate, pode dar dinheiro, mas pode dar barroca. (A cana) não endireita mas também não derruba". Contam que a pouco tempo atrás houve uma discussão a respeito dos postes que passam pelo bairro. A companhia de energia elétrica exigia que os proprietários mantivessem distância dos postes de madeira, com suas lavouras de cana, pois já ocorreram casos em que eles foram queimados (junto com a cana, acidentalmente) e a fiação caiu no chão, com risco de vida pra comunidade. Alguns proprietários levantaram então a questão de que no passado, havia sido sugerido o uso de postes de concreto, e a empresa havia recusado. Agora o ônus recairia sobre os proprietários (aceiros maiores, perda de faixa de lavoura), por culpa de uma decisão mais conveniente à empresa, naquela época. 
Carlos encontra dificuldade na fase atual de desenvolvimento de granja de frango, em que enfrenta problemas trabalhistas, reclama que é muita "dor de cabeça". Gostaria de ter boi (a limitação é pasto), algodão (ma essa lavoura exige muito trabalho e a mercadoria está com preço ruim), e "tudo o resto (lavouras) o limite é a irrigaçảo, que é cara, já de início (em relação ao investimento necessário)".

Pensou em construir tanque (porque na partilha da terra ele ficou sem), mas desistiu porque ia ter que plantar 50 ou $30 \mathrm{~m}$ de árvores.

Para Cláudio "Falta de terra pra plantar" é a maior dificuldade. Tinham granja de porco (antes do programa): "trabalhamo muito mas não aproveitamo. Hoje tá bom. A cana só ajudou. Hoje a cana tá abandonada pelo govemo.

"A estrada tá ruim. Precisa abrir sangra, cascalhar e fazer bem feito. Manutenção dela (tem sido) só uma vez por ano."

"O preço da cana não é mais fixo, é de mercado." Eles têm que negociar com a usina, e avaliam que as coisas pioraram com isso. Mas acreditam que isso poderia ser resolvido, revertido, em favor da conservação ambiental, valorizar mais a cana do pequeno produtor, pois ela "é uma solução preciosa.

"Se não chove, como esse ano, prejuizo na lavoura. Sem cana não dá." Antes produziam 1500 ton de cana pro sustento; hoje precisa produzir 6000 ton. Reclama que as coisas ficaram mais difíceis e que seu medo é que as usinas fechem.

Disse que gostaria de criar rã, ou ter tanque de peixe, mas lembrou do problema das pessoas querendo pescar.

Com a cana ele não tem tanto prazer como teria se fosse uma outra lavoura; ele não gosta muito.

"(Os produtores rurais) plantando lavoura junto prejudicam-se (devido à maior competição e tamanho reduzido do mercado em que têm acesso); mas se é cana, só ajuda (pelo maior volume de produção e preço maior, mais facilmente negociado).

Sobre a piscicultura na microbacia, ele acha bonito. Como tem pouca terra, pensa que pode ajudar na renda da família.

Já para Mateus e Gustavo a dificuldade está na "Política de preço da cana. Caro pra produzir e barato pra vender."

Trabalha com cana, porque permite previsão. "É pouco lucro e baixo risco; é muito segura. Com tomate não dá, é mais frágil."

Já não pode mais fazer tanque, porque não pode mais desmatar."

Quando pergunto sobre a vontade de desenvolver outra atividade econômica: "Não dá pra pensar. Com o frango, escala (de produçảo) é a dificuldade; (é atividade que na região) iniciou e já não é bom de começar agora. Piscicultura (já está acontecendo) a mais de 5 anos. Falam (frente às vantagens de mercado) em porco." Mas diz que pra construir uma granja, seja de porcos ou de frango, precisa de alto investimento em capital, entre 70 e 100 mil reais.

Sobre seus sonhos, diz que não sonha: "muita insegurança; futuro incerto". Cita as reuniōes que já estão acontecendo pra que não se queime mais a cana: "não queria mudar (da cana); queria que melhorasse." Reclamam da falta de incentivos, da falta de "máquinas à álcool". Acha que seria bom pra todos converter motores a gasolina/diesel em álcool. Mas se sentem de fora das discussões, "a Cooperativa não tem voz. Collor de Melo é que era usineiro, e melhorou muito."

"Na propriedade, tudo com orientação, tudo é aferido." Eles dizem ter cuidado com os produtos. Mas concordam que muitos realmente não fazem isso. Lembram, porém, que 
: "em lavoura, não existe perfeição; o tempo (climático) é muito difícil (no sentido de não poder prever algumas coisas, como chuvas intensas). Todos têm um pouco de árvore no sítio".

Estevão diz que "Falta chuva. Falta preço na mercadoria. Falta incentivo do govemo pra tocar lavoura."

Dificuldade de financiamento: "é mais fácil pra cana que pra berinjela. (Juros de) 9,5\% ao ano, empenhora tudo (pra poder conseguir o financiamento)".

Produz "Cana, berinjela - mais recente - , tomate, cereais: arroz, feijão, pra venda. A cana é fraca porque a terra é pouca." A berinjela começou pra ver se aumentava o ganho, porque a "cana não dava." Com a berinjela tira "até 2 safraslano, mas o preço não ajuda".

Sobre desenvolver outra atividade econômica, diz não ter opção nenhuma. Mas gostaria: "granja, boi em confinamento, ampliar a propriedade. Sempre trabalhei com gado; depois ficou ruim.

"Falta dinheiro. Tirei peixe (do tanque pra vender) e não posso por mais, por falta de dinheiro."

Não pensa em sair. "Se pudesse vender e comprar melhor até pensava, mas não dá. Familia toda aqui já a 30 anos", e o filho (já casado e com filho) pensando em ficar com ele, pra tocar junto.

Planta tomate em Tietê. Já plantaram tomate aqui, mas deu problemas de tiririca e pragas.

Ele foi um dos primeiros a ter peixe. "Hoje todo mundo tem e cai preço. Tem que comprar alevino. Tem financiamento, mas não peguei aqui. PRONAF (verba do programa de valorização da produção familiar) não chegou. Não deram. Tem financiamento mais barato pra alevino. Assistência técnica até tem, na Cooperativa dos cortadores de cana. Fazem reuniöes na Casa da Agricultura, mandam convite, tem técnicos." Ele diz que não tem participado muito por falta de tempo; muitas reuniões são visitas à propriedades ou locais fora da região. Seu tanque ele fez "da cabeça".

Sobre a queima da cana: "É raro escapar um fogo. Uma vez escapou fogo da usina e pegou na capoeira.

Leonardo diz não ter dificuldades.

Para Luis, "Depois do plano cruzado as coisas do sítio não têm valor; vâmo vivendo". Mesmo "se pudesse ter um boizinho, uma ovelha... não vende mais fácil como antes. 0 que segura é a usina, todo dia 5 paga. Com o tomate, ou se fica rico ou fica sem nada". "Primeiro era a inflação alta, mas o produto também tinha valor". Ele se diz não saber avaliar ainda o real, "tem que esperar um pouco mais".

Água do tanque, para higiene é limpa, mas quando ela chega suja muito a caixa. É a mesma que serve à criação. A água do poço é pra beber. "Tá precisando de um poço artesiano de $\pm 150 \mathrm{~m}$, que fica \pm em $R \$ 10.000$.

Gostaria de plantar tomate. Não faz por falta de capital e por considerar muito arriscado pegar o dinheiro dos bancos.

Sobre a piscicultura, ele diz não gostar: "não adianta. Tanque tem que ser perto da casa; se for longe roubam tudo com rede, como já aconteceu com ele.

Sobre um programa de saúde, conta que existia na usina um plano chamado CEPASA, voltado para acidentes de trabalho, quando os pacientes eram mandados pra Piracicaba, Campinas e tal plano cobria as despesas. O hospital também foi feito, 
descontando-se dos fomecedores. Ércio Bresciani e Cristina acabaram com o hospital. Hoje são 3 médicos que se revezam em tumos (atendimento gratuito) e se é caso grave tem que dar depósito de R\$2000 de garantia, pra depois eles devolverem o que não foi usado. Existe hoje o convênio com a UNIMED, mas para os casos de internação, paga-se 'por fora' (o convênio não cobre). Então ele decidiu pagar mensalmente. Conta que numa ocasião, quando precisou ir à Piracicaba, a UNIMED cobrou dele $R \$ 170,00$ pra uma viagem até Piracicaba $( \pm 30 \mathrm{~km})$, alegando que ele deveria ir deitado, acompanhado de enfermeira, e chegando lá, só podia se locomover em cadeira de rodas. Alegaram que era responsabilidade do grupo levá-lo até Piracicaba em segurança, mas ele se irritou porque dizia estar em ótimas condiçōes pra ir de carona com amigo, a um custo muito menor.

Lucas diz que antes tinham mais dificuldades, sem água de poço e sem luz elétrica. "Hoje é o preço (dos produtos)". Tem "problemas de sistema de água pra tanque de peixe". Já pensou em granja, mas (têm) muitos fazendo, resolveram desistir. O melhoramento que precisa fazer é barracão pras máquinas.

Thaís conta que fizeram uma primeira tentativa de produção de leite mas não foi bem. Num segundo momento tinham um rebanho bom e produziam leite $B$, que não precisava de CIF na época (o que simplificava a estrutura demandada pra produção e não encarecia o produto final). Lutaram pra conseguir a infraestrutura necessária pra ensacar (na própria fazenda) e vender em Capivari, mas houve muita reclamação por parte do pessoal que vende com carrocinha; então o promotor exigiu o CIF (segundo ela, o argumento utilizado foi o de que o leite de carrocinha o consumidor vê, pois é despejado na sua frente, e no saquinho isso não seria possivel). Então abandonou a atividade. Seu sobrinho vem desenvolvendo um secador de fnutas, sem dificuldades. Pra fazer um tanque acha complicado, tem medo. Tinha vontade de desenvolver a piscicultura na propriedade, mas precisaria de uma pessoa jovem. Gostaria de poder fazer isso.

Para Raquel, a dificuldade está em "Ganhar dinheiro, ter lucratividade". O desafio não é técnico, de produção. "É mais a condição climática. "Preço, comprador... receber é dificil". Muitos trambiqueiros.

Sobre a produção orgânica, vê algumas limitações: falta de mercado, tecnologia e por ainda não acreditar na viabilidade técnica desse modo de produção aqui nas nossas condições. "Não temos inverno aqui; nos EUA é mais sério e ambiente ajuda"(a respeito da neve que acaba com quase tudo, promovendo um tipo de 'limpeza' no sistema).

A respeito da piscicultura na microbacia: "Tem que dar um jeito nos pescadores. Pesque-pague não compensa. É complexo (trabalhar com aglomerações). Já cortaram pau, fazem fogueira, destruiram placa". Já tem vários pesque-pagues na região. Alguns já vendem. Seus empregados pescam muito, comem peixe. O uso de rede só é permitido com sua autorização.

Sua visão das dificuldades enquanto presidente da Associação: levantou alguns problemas de adaptação dos interesses e planejamento da usina, à realidade das propriedades: variedade (BRIX x longevidade da soqueira), cuidados com a soqueira. Cerquilho, por exemplo, já usa variedades diferentes que Capivari. Para o proprietário é interessante que a cana renda um maior número de cortes, mas a usina paga por BRIX e valoriza a produtividade, qualidades que se concentram nos primeiros 
anos/cortes. O pessoal tem que estar mais atento e cobrar qualidade no corte de sua cana (feito pela usina), devido à soqueira. Cobra deles, nesse sentido, maior participação e se imita com a situação. Porque existe sempre o risco de perda de ágio por maus tratos na soqueira. O modo de avaliação do volume produzido também dá margem pra confusão. A estimativa dos proprietários é pouco precisa. Existem então alguns problemas entre o planejamento da propriedade e o da usina.

Existe uma acomodação, porque a cana tem preço fixo, por lei, até hoje. Mas isso muda em maio agora (98), quando ele vai ser liberado; será o preço de mercado. A associação trabalha com 2 milhões de ton de cana e esse novo contexto vai exigir um trabalho maior em cima da produtividade, e de pensar as áreas não-mecanizáveis. "O risco é de quebradeira feia". Ela entende que o proprietário precisa:

usar mais a orientação dos técnicos da associação (orientação sem custo adicional e prontamente disponivel, basta procurar);

não negociar sozinho, por conta própria;

reduzir seus custos a aumentar produtividade.

Geralmente a orientação não vai até os proprietários. Exceção foi feita, por exemplo, para uma lavoura de tomate, onde o técnico foi enviado para traçar as quadras (dado o alto risco de perda de solo e contaminação de mananciais) e para alguns cultivos que apresentem produtividade baixa. Quanto à análise de terra, a associação possui uma norma: não vai até a propriedade pra tirar amostras. Ensina o proprietário, e este é que deve encaminhá-las à associação. Eles não teriam pessoal suficiente para tal, e pensa que seja realmente obrigação daqueles. Mas os técnicos sempre estão disponiveis pra tirar dúvidas, etc.

Nas reuniões com os proprietários, na Associação, "eles não entendem e trocam tudo". É difícil atraí-los para encontros desse tipo; "eles têm que aprender que o negócio é deles". A estratégia do churrasco já deu certo uma vez (pra atrair a moçada), mas ela é contra, esperando que os proprietários queiram ir às reuniōes por se tratar de assunto de seu interesse. "Não entendem e não perguntam, esse é o grande problema". "Pessoal é dificil de entender; a gente fala, fala na associação...é 'catequese' constante, mas enquanto não mexe nos bolsos dos caras eles não mudam - produtor de cana virou vagabundo. Não dá conta da responsabilidade com o vizinho, com o ambiente".

\section{1b) Principal fonte de renda dos proprietários}

Para José e Ana é a aposentadoria que os dois (casal) recebem e a cana (recebem sobre a produção de 600 t lano: $32 \%$ é da usina, $30 \%$ é pago ao produtor na entrega e o restante é pago em 4 vezes. Antigamente o pagamento era de uma vez só, e eles mesmos (o casal) cortavam e levavam pra usina, de carroça. Dai foi proibido por lei esse transporte. "Era duro queimar (a cana) na madrugada". Já apagaram incêndio de noite. Hoje a usina tem canhão d'água. Antes costumavam trocar serviço entre os vizinhos; hoje paga R\$ 150/alq pra turma plantar, porque eles sozinhos não dão conta mais, "mas comecei em 62 essa vida!".

Usina media com 'vara' (pra estimar a área da tarefa cumprida; contou que a vara diminuiu de 5 pra $4 \mathrm{~m}$ mas o pagamento continuou igual). Hoje é tonelagem. Antes tinha reajuste, que chegava constantemente pra eles: Hoje é por sacarose: "se dá mais doçura consegue os 30\% (nas duas parcelas). "Mas isso só (se consegue) se cortar de setembro pra frente". 
Joaquim diz viver da terra, mas além disso trabalha na cidade, ganhando 1 salário.

Para seu irmăo Carłos, era a granja, que atualmente está parada. Hoje é mais a cana. Quem administra tudo hoje é o filho, ajudando toda a família. Tem também a ajuda aposentadoria.

Cláudio diz que é a cana. Tem conseguido financiamento bom, com juros baixos; Mas só pra cana.

Para Mateus e Gustavo a principal renda também vem da cana, assim com para Luis, Raquel, e Leonardo (embora fora do contexto da propriedade a principal renda deste ultimo esteja no supermercado, em Capivari, o qual é dono)

Na propriedade do Estevão cana e berinjela se dividem, em importância.

Para Lucas são a cana e tomate.

Cana e pecuária (empresa de transferência de embriões) são as principais, para Thaís.

\section{1c) Tomadas de decisסes}

"Tudo junto (o casal)". (José e Ana)

Joaquim toma as decisões sozinho. Carlos conta com a ajuda do filho

Cláudio diz que são tomadas em família. Todos trabalham na roça, os filhos inclusive. Até o vizinho participa, dando conselhos, ou no caso dos plantios trocando mudas. Por causa até das várias variedades de cana, onde a experiência de um pode ser valiosa pros outros.

Sempre combina junto, em família. "A usina também ajuda, trazendo variedades novas, esclarece, ajuda." (Mateus)

É o Estevão mesmo quem as toma, consultando a familia, principalmente o filho. Antes decidia junto com os irmãos.

Na propriedade de Leonardo, é o filho quem as toma.

Luis toma as decisões sozinho, mas consulta a familia.

Lucas as toma junto com irmão e filhos.

Raquel diz que a responsabilidade é só dela, mas consulta várias pessoas pra tomar as decisỏes. 


\section{1d) Condiçōes do arrendamento}

José e Ana contam que a produção mínima (aceitável) é de 150 talq, em 4 ou 5 cortes. Alguns lotes novos chegam a 300 t/alq. Faziam antes, em média, 150 a 200 talq. A desvantagem do arrendamento é que a usina cobra de 30 a 40 t/alq (cerca de $25 \%$, só pelo arrendamento). Antes o ganho era maior; trocavam serviço entre eles e tinham carreta pro transporte.

Trabalhavam na terra de um amigo, arrendando. Tinham um trato bom (representava uma boa receita pra ele). Aquele amigo perdeu terreno com as árvores; tinha um trator novo que não compensou, com o pouco terreno, e vendeu. Esse amigo preparava a cana dele também. Com a 'floresta' tudo mudou. Mudou o acordo (se desfez).

Cláudio e Mateus não fazem. A usina só corta e transporta.

Estevão também não faz, porque: "muita pouca área; não compensa". Se tivesse área arrendada pra usina, acha que ela é que teria resolvido os 'problemas de mata'. Assim também Leonardo: não arrenda; usina corta e leva, cobrando $30 \%$.

Luís não está arrendando mais pra usina. Arrenda uma parte pra particular. Na outra ele mesmo faz o aceiro, a queima, o corte e o transporte. Enquanto dá pra trabalhar não vale a pena arrendar.

Lucas confirma: "Não vale a pena o preço (pago no arrendamento)".

Thais arrenda 120 alqueires, a 51 ton/alq (25\% de ágio). Recebe mensalmente.

Raquel não arrenda. E a usina corta apenas uma parte pequena, entre 15 e $20 \%$.

\section{1e) Avaliação da assistência técnica}

José e Ana compram (insumos agropecuários) na cooperativa e daí eles já orientam. Mesmo que não peça orientação já paga 3\% (ou R\$ 3,00; não sabe bem) do valor da compra, que é destinado pra manutenção desse serviço. Mas tem que ir lá. "De graça é (quando precisa) tirar o nivel, vai com aparelho. A qualidade (do serviço) é boa".

Joaquim e Carlos disseram que quando procuram, em Capivari, recebem a assistência técnica da 'Casa da Lavoura' (Casa da Agricultura de Capivari), pelo eng. agr. João Castelani. "Pra perguntar, analisar terra. Ela oferece serviço de análise de terra". Ele precisaria colocar de 7 a 8 ton de calcário/alq (disse que custa em tomo de R\$ 14,00 a tonelada, e um caminhão carrega 10 ton). Ele diz não usar muito esse serviço (de análise da terra), por não ter dinheiro pra fazer as correções necessárias.

"Na época do carvão da cana, veio um pessoal de Piracicaba. Pra cana tem orientação."

$\mathrm{Na}$ questão de 'conservação dos recursos naturais', disse que "só (recebeu assistência) quando saiu lei pra plantar árvore".

"Eles (da Casa da Agricultura) vêem que pouco podem fazer, porque o que tem mais é a cana mesmo." 
Cláudio recebe da Cooperativa/Associação, do agrônomo responsável. Avalia como bom; promovem reuniōes, analisam terra gratuitamente, orientam sobre o uso do calcário, além de facilitarem a compra.

Na avaliação de Mateus e Gustavo, "É boa a da Cooperativa. Fazem análise do solo, palestras; alguns engenheiros pra tirar dúvidas, pra conversar. É suficiente. Se o preço (da sua produção) fosse melhor, usava mais tecnologia (que lhe é oferecida)."

Segundo Estevão: "Nada até hoje. Nem Casa da Agricultura nem nada, pra lavoura. Tem que ir atrás".

$\mathrm{Na}$ condução das lavouras, controle de pragas, se for procurar na Cooperativa encontra. "Nunca vieram. Nunca teve programa pra incentivo."

Em relação ao uso e conservação de máquinas: "Nada. É do bolso. Nem incentivo, nem orientação. Só do fabricante, mas aí paga."

No caso de Leonardo, o filho mesmo faz; os alinhamentos (dos lotes) a cooperativa faz.

O que precisa, pede à cooperativa e ela faz: curva de nível, veneno pro mato, ajuda de um agrônomo, análise de solo, medir terra. "Só paga se for pra escritura. Considera a assistência boa. (Luis)

Lucas descreve assim a assistência técnica:

Da Associação: tirar o nivel, análise de terra, da cana.

Da Cooperativa: usam os produtos (insumos) agrícolas e recebem orientação de técnicos especializados.

"A Associação com máquinas, a Cooperativa com equipe; difícil é atender a todos (pra melhorar dependeria de outros fatores, por ex.: "todos precisam na mesma época').

Dentro da Associação tem CREDICAP, CANACAP (cuja contribuição é como a jóia em um clube), e a ASSOCAP (que pelo artigo 36, é descontada uma taxa - revertida em serviços -, e tem outra taxa ainda descontada para ser possivel o pagamento em sacarose - é o que mantém o laboratório de análises).

Thaís recebe assistência da Associação para amostras de solo e medição de lotes. $\dot{E}$ um serviço gratuito. Não trabalha com a Casa da Agricultura.

\section{1f) Sugestões para melhorar esse serviço}

José tem uma: ter um estoque melhor de produtos. "O estoque é ruim". Já teve que ir buscar produto em Elias Fausto, por que estava em falta no estoque da Cooperativa.

Para Joaquim e Carlos, "Qualquer ajuda já seria bom.(...) A semente da Casa da Agricultura não é boa."

Estevão sugere: "Que ele existisse"

"Que o govemo desse mais valor pro povo do sítio; as coisas valerem mais..." (Luís) 
Lucas, assim como Thaís, não tem nenhuma sugestão, já considera bom o atendimento. "Fazem bem, dentro do possível".

\section{1g) Avaliaçăo das escolas do bairro, infraestrutura de apoio à saúde, alimentaçăo, encontro social}

"Escolas só na usina; não tem muita criança (no bairro) e o que tem trabalha na lavoura."

Não têm postos de saúde ou igrejas. Armazém mais perto é o do Menegon, a $6 \mathrm{~km}$ dali.

Carlos e Joaquim dizem que têm direito ao hospital, através da cana que fornecem.

Cláudio diz que isso "Só em Capivari."

"Tinham escolas. Em 45 a professora ia de trole; a usina União São Paulo era de um francês." Quanto à infra-estrutura geral, "tudo em Capivari." (Mateus)

Sobre as escolas, diz Estevão: "A prefeitura pega de ônibus e leva pra usina São Francisco (IASF), pra aula. A prefeitura que paga. Era boa a escola perto. Agora piorou."

Seus filhos estudaram nessa antiga escola. Sua esposa é merendeira. Agora já faz um ano que fechou.

Postos de saúde e armazéns, só na cidade. Não há igrejas no bairro.

"O que piorou muito foi o governo tirar as escolas do sítio. É gente muito simples. Agora vão pra cidade ou usina e querem comprar o que as outras crianças compram (sorvete, lanche). Por que não traz uma professora em vez de levar todo mundo pra escola? Por que não fez uma pesquisa pra saber, pessoal era contra!". Luís diz que a chegada da luz já era pra valorizar mais o campo, "pro pessoal não ir muito pra cidade, e agora tira (o pessoal de lá) pra levar pra. escola?". O vizinho acha que como. está é bom porque ajuda a conservar mais a estrada, levando pessoal pra cidade (obrigando a prefeitura a zelar pelas vias rurais). Lembra que a escola não é só pra funcionário, mas pra todo mundo que mora ali.

Pra comprar mantimentos, só na cidade. Sementes e produtos agropecuários tem na cooperativa.

Segundo Lucas, a Prefeitura prometeu fazer escola (ali no bairro). Ele então doou a casa. Depois tiraram de vez a escola, dizendo que a casa era pequena. Era muito importante para os trabalhadores. Hoje passa ônibus pra levar pra Capivari.

O marido da Thaís montou escola em 46, que funcionou até pouco tempo atrás, quando a prefeitura tirou todas as escolas rurais e passou tudo pra usina, prometendo transporte. Hoje prefeitura vem dizer que não pode mais fazer tal transporte dos estudantes. Ela (proprietária) não tem condiçōes de levá-los até lá. No total foram 4 escolas 'desmontadas'. 
Saúde só na cidade. O hospital (da Associação, cujo marido é fundador) passou pra UNIMED e ficaram com pronto-socorro. Plano de saúde (para os funcionários) sai caro, por ser familiar, e atendimento é na Santa Casa. Os postos de saúde são fracos. Ela acha errado não ter assistência aos empregados só por ela ter passado a ser arrendatária (e não mais fomecedora), mas eles (da direção da Associação) não aceitam.

Lazer também só em Capivari.

Raquel diz que a "escola da [Thaís] é de 54".

\section{1h) Avaliaçőes institucionais}

\section{Universidade}

Carlos e Joaquim dizem que "Ajuda, é bom."

Estevão diz que "Não muda em nada. Não contribui. Nunca procuramos."

"Sem contribuição pro pessoal de cá. Precisa de faculdade em Capivari, pro pessoal não ter que ir pra fora. Dificil ter que ir pra Piracicaba". A filha do Luis, com magistério vem passando por dificuldades.

Lucas diz que conhece. Já precisaram da ESALQ: mudas de tomate; os professores atenderam bem.

O marido da Thaís era agrônomo, e as mangueiras da propriedade (muitas) foram plantadas e cuidadas sob orientação da ESALQ.

\section{Casa da Lavoura (Casa da Agricultura)}

"A gente quase não ocupa ela. Antes pegava semente. Não sei se tá funcionando." (José)

Cláudio diz que ela trabalha junto com a Cooperativa; é boa pra eles.

"É boa. Se precisar de orientação dá. Convidam pra projetos. Têm boa vontade." (Estevão)

"É cabide de emprego. Nunca resolveu nada. Tem que ir lá prestar conta 3 vezes por ano das vacinas, do número de cabeças, doenças". (Leonardo)

Segundo Luís, como a cooperativa já ajuda, não tem precisado dela. Já precisou no passado. A cooperativa foi melhorando de lá pra cá.

"Palestras; de vez em quando passa aqui.(...) Palestra em 96, instruindo. Era promovida pelo SENAR. (...) (Assessoria na) parte técnica a gente nem procura". (Lucas) 


\section{Cooperativa dos Plantadores de Cana de Capivari}

Carlos e Joaquim nunca foram procurar. Diz que os produtos que tem lá, têm o mesmo preço de outros lugares.

"Ajuda com informação e orientação, se for atrás. Tem reunião, tudo", tanto a Cooperativa (que Estevão não diferencia da Associação) como o Sindicato.

"Só não tenho dinheiro pra fazer as idéias deles, a tecnologia". Não tiveram nenhuma atuação durante o programa. "Não reclamaram".

No sindicato faz papelada do INCRA (com Toninho Godoi).

Luís pega financiamento com ela pra 30 dias. Pega também do Banco do Brasil.

Tem advogado à disposição. As reuniōes são sempre por iniciativa dela. (Mateus e Gustavo)

Lucas faz cadastro e paga taxa pequena. Tira produtos (insumos agropecuários).

Cláudio conta que em certa ocasião soube que haveria uma reunião do programa na fazenda da proprietária onde está a represa. Não gostou da idéia, procurou a orientação do advogado, que não sabia de nada. Ficou indignado com o fato do próprio advogado da Cooperativa não saber de nada, e levantou algumas suspeitas de favorecimento da proprietária, em cuja propriedade tinham se iniciado os plantios. A reunião acabou sendo transferida para a Cooperativa.

"Por que não foi feita uma reunião de esclarecimento?" Questiona o papel do advogado que não cumpriu sua função, de estar a serviço dos cooperados.

\section{Associação dos Fornecedores de Cana de Capivari}

Para Carlos e Joaquim, Associação e Cooperativa são uma coisa só.

O mesmo para Cláudio e Roberto. Eles participam, é como se fosse uma única instituição (a Cooperativa).

Luís não sabe se faz parte do sindicato, mas acha que tem algo na Associação (pra declaração de Imposto de Renda). Talvez pague uma 'taxinha por mês', não sabe.

\section{Consórcio Intermunicipal das Bacias dos Rios Piracicaba e Capivari}

José e Ana não conhecem.

Carlos não conhece, mas já viu na TV. Sabe que "eles têm dinheiro pra trabalhar pra isso (o programa)".

Mateus e Gustavo dizem que não conhecem. 
Quando perguntado se conhecia, Estevão respondeu: "Nada. Sei que vai plantar, mas não sei da finalidade que eles querem."

Leonardo diz que não conhece. Perguntei sobre o contrato, onde aparece o nome do Consórcio; disse que nem leu o contrato. Lembra da promessa que eles não cumpriram.

Não conhece. Ouviu falar, mas não sabe. (Luis)

Lucas não sabe se atuaram por aqui (Forquilha).

Thais e Raquel conhecem.

Pedro (IASF) sabe que existe, porque passa na TV, mas não conhece bem.

\section{DEPRN}

José e Ana, Joaquim e Carlos, Estevão, Luís, Thaís não o conhecem.

Lucas viu uma vez só eles por aqui. Informação a respeito da isenção de imposto sobre área com mata. "Só vieram pra vistoriar, com o levantamento da Casa da Agricultura em mãos". Ele acha que [Antonio] (engenheiro autônomo do Consórcio) trabalha pra eles.

Pedro já ouviu falar dele.

\section{CESP}

José e Ana não conhecem.

Joaquim e Carlos conhecem, mas dizem que ela não atuou no programa.

Cláudio não sabe ao certo, porque o nome aparece no contrato. Gostaria de esclarecimentos.

Mateus não sabe do envolvimento dela no programa.

Estevão diz que CESP "É da energia elétrica."

Leonardo conhece a instituição, mas diz que ela não estava envolvida, que ele saiba.

Luís diz que só pode falar mal. Quando foram passar a força, deixou, e assinaram permissão. "Atendimento é ruim e preferem cortar a força do que conversar. Deviam ter mais consideração, avisar melhor os atrasos, melhorar a comunicação (a respeito da mudança na cobrança da conta, que passou a outro banco, e criou alguma confusão, levando o proprietário a atrasar seu pagamento; a CESP teria mandado um 
funcionário cortar a força da propriedade, que por sorte era conhecido seu e ajudou a resolver o problema)".

Thais diz que conhece, mas não esteve envolvida.

Para Pedro, ela não teve atuação.

\section{Fundaçāo Florestal}

José e Ana, Joaquim e Carlos, Cláudio, Mateus, Estevão, Luís, Thaís, Pedro não a conhecem.

Lucas diz que ela não teve ação por aqui.

\section{Polícia Florestal}

José diz que "nunca teve por aqui."

Carlos conhece, mas não vieram. Brincou dizendo que costuma ver helicópteros sobrevoando o bairro, fazendo fotografias, que talvez fossem eles, vigiando as matas. Mas sabem que tem um pessoal do Paraná que faz sobrevôo de avião pra vender fotos das propriedades.

Cláudio já ouviu falar mas nunca tiveram (a Polícia Florestal e o IBAMA) nenhuma ação por lá.

Mateus diz que ela nunca veio.

Não aparece por lá, diz Estevão, assim como Lucas.

Leonardo sempre ouviu falar que ela estava em cima; diz que se fizer 'cagada' ela logo aparece em cima.

"Conhece, mas no programa não ajudou, nem estorvou". "IBAMA é gente que proibe a caça, sou a favor dessa gente". (Luis)

Thais conhece. Diz que a Policia Florestal apareceu na propriedade quando ela plantou alfafa na beira da represa, mas a questão foi resolvida sem autuação.

Pedro diz que ela já veio, mas não no Forquilha. Tem contato com eles devido às queimadas: toda vez que vai queimar envia fax, semanalmente.

\section{IBAMA}

"Tudo do meio ambiente é pelo IBAMA de Piracicaba." (José)

Carlos ouviu falar, mas não sabe dizer o que faz. "Comigo ninguém veio".

Mateus e Gustavo conhecem mas nunca passou por lá. 
"Nunca veio." (Estevão)

"Conhece, mas no programa não ajudou, nem estorvou". Luis fala da Polícia Florestal e também do IBAMA."IBAMA é gente que proibe a caça, sou a favor dessa gente".

Lucas diz ser o mesmo órgão que a Secretaria do Meio Ambiente, onde teve que ir, em Piracicaba, pra assinar o contrato (por exigência de Ester).

Segundo Thaís, não vieram por aqui.

"Não atua aqui." (Pedro)

\section{Prefeitura}

"O prefeito prometeu um telefone público, mas este não é muito útil, porque ninguém atende e não tem como as pessoas deixarem recado." (José e Ana)

"Deveria zelar mais pelas estradas, colocar mais pedra, abrir mais, passar mais máquina". (Luis)

\section{Instituiçỏes de crédito}

José diz que Banco do Brasil empresta pro pequeno agricultor a $12 \%$ ao ano. Pra ele o limite é de $\mathrm{R} \$ 5600,00$. "Já caiu pra $9 \% "$ ". "O crédito é meio complicado; podia facilitar (todos os herdeiros precisam assinar, para a hipoteca exigida)."

Já na Cooperativa (setor de crédito) "é uma beleza! Qualquer um assina, não tem limite, não hipoteca, não precisa dos herdeiros... não pede nada; é mais simples. Melhor que banco. Juros de $4 \%$ ao mês, $16 \%$ ao ano."

Carlos faz empréstimo no Banco do Brasil, mas quem sabe detalhes é o filho, atual administrador do sítio. Joaquim não faz.

Mateus e Gustavo pegam crédito, sem dificuldade, no Banco do Brasil, na Cooperativa.

"Pra cana é mais fácil. No banco do estado, Banco do Brasil, tem muita exigência. Prazo difícil. Cliente bom de cumiculo até consegue." (Esteväo)

Leonardo não usa, paga por conta.

Thaís negocia com o Banco do Brasil, mas recentemente não conseguiu financiamento pro milho; disseram que pro grande (proprietário) e pra pecuária não teria crédito.

\section{Sindicato}

"Não ocupa, não usa." (José e Ana) 
Joaquim e Carlos fazem parte. $O$ patronal eles não pagam.

"Ótimo, facilita bastante. Dão orientação sem cobrar nada. É mais trabalho de escritório: serviço de despachante, mais barato e sem burocracia." (Cláudio)

Segundo Mateus, tem advogado, despachante a preços melhores e é menos burocrático. "O Sindicato Rural... hoje orientam em tudo; na época não tinham."

Estevão diz que no sindicato faz papelada do INCRA (com Toninho Godoi).

Luís não sabe se faz parte. Acha que tem algo na Associaçăo (pra declaraçăo de Imposto de Renda). Talvez pague uma 'taxinha por mês', não sabe.

Lucas e Miguel participam e pagam taxa que está incluida no ITR.

\section{Sobre aspectos relacionados à adesão ao programa e seus impactos}

\section{2a) Mata ciliar}

José e Ana acham que a mata ciliar é boa: "cria a passarinhada e ficou bonito. Mas pra quem tem pouca (terra) prejudica. Lucro não dá pra ninguém, só prejuízo. Se fosse fruta, o passarinho comia, mas só (plantaram) essas árvore que não vale nada: sangrad’água e 'taxipingui', dá muila praga e cai cedo, logo que é arvinha".

Uma sugestão que dá é de que o capim é bom para os $30 \mathrm{~m}$, solia a criaçăo e ela mantém. Outra é a de não cortar o que tem. Conclui dizendo que pra eles ali a mata ciliar não serve pra nada.

Depois do plantio fizeram estufa (próxima aos plantios); hoje a sombra e a "raizama" (raizes das árvores invadindo a estufa) formados estảo prejudicando a estufa, principalmente a sangra-d'água, cuja raiz ele diz 'brotar' (diz isso por ver muitas plantas pequenas nascendo em volta da árvore).

A respeito da proibição de se fazer o tanque em seu próprio vale: "Não causaria problema algum, sem poluição nenhuma (caso fosse feito no vale)".

"Não tem ajuda pra alevino; ninguém falou nada sobre ajuda". Na época tava $\mathrm{R} \$ 100$ o milheiro, hoje tá $R \$ 120$.

"Se largasse pra trás, ia formar do mesmo jeito, (só que) mais demorado". (Joaquim)

"Fica mais bonito; mais sombra, (e por isso) consome menos água (criando uma área mais úmida)". (Carlos)

"É bom ter árvore na beira do rio; sombra pra ficar lá. Se fosse bem feitinho seria bonito. Se todos plantassem e zelassem. Pro ar é bom. Não sei. Gosto de árvore... no lugar certo... onde não se ocupa." Tem lugar onde Cláudio não quer plantar, e considera esse um lugar ruim pra se plantar.

Dá algumas sugestőes: limpar o rio (dragar), plantar bananeira, árvores frutiferas. Tirariam proveito e zelariam. Seria um benefício público. " Não seria mais sua 
propriedade e poderia doar as frutas pra creches, além do proprietário poder fazer uso, os pássaros. Além do que 'teria o verde'.

"O técnico disse: 'mas isso é mata ciliar, não é pra tirar proveito' ."

Mateus considera que é bom, mas "não tiro nem mais um centavo (pra ajudar em sua formação). Ou o govemo deveria desapropriar a área - e $80 \%$ do valor já estaria bom, perdemo o direito de mexer mesmo - ou pagar a renda da terra.

Não é contra. A única ressalva que faz é perder a terra: "se desse estímulo resolveria o plantio." Plantariam mais se pudessem.

"Mata pra água é bom", Diz Estevão. Já no assunto dos plantios: "É área que não vai servir pra nada. É área que vai ficar inútit. Só vai segurar a terra melhor. Pode melhorar pro futuro, na nascente apenas. Pode ser até que aumente a água no futuro."

Luis acha importante: "tem lugar que ela é importante, tem lugar que ela atrapalha, onde vai feijāo, arroz, cana, milho. Ele tem 'mato' na propriedade e "queria poder usar mais (a área, pra lavoura)". "Onde o chão é torto (barroca) tudo bem".

$\mathrm{Na}$ área onde hoje é o tanque, Lucas diz que quando chovia o terreno encharcava demais pra cultura, e na seca, secava muito o solo (solo ruim pro cultivo). Acha hoje que é "excelente coisa, assim como o terraço", porque depende da água, e não vai querer sujá-la.

A área que perde nảo faz diferença, diz ele. É "como um investimento".

Nảo tem outra idéia, "tem que ter esse mato que vem em volta (do recurso hídrico). Já um pomar teria que limpar (ele pensa em colocar frutiferas na beira da APP)".

Agora que está mais conscientizada (através das coisas que lê e vai escutando, vai mudando) Thais acha que é bom. Na época achou muito ruim, difícil (porque toda a terra estava ocupada com cana). Não tem sugestōes altemativas ao plantio das ánores na faixa ciliar.

Raquel acha que é importante. Proteções , embelezamento, refúgio de animais.

Pedro considera a mata ciliar "fundamental pra própria subsistência da própria água". Ele obsena que toda cabeceira é formada por ámores, que as protege. Tem observado lugares onde se retirou essa vegetaçảo, e que a nascente reduziu ou 'se mudou' para outro ponto.

\section{2b) Adesão espontânea}

José e Ana dizem que não foi espontânea, foram obrigados. "Se vai se queixar toma multa e daí é pior, né? Melhor passar de bobo e não tomar...". "Ninguém gostou, mas se é lei federal, fazer o qué..."

"Vieram, tiraram fotografia, fizeram mapa. Chamou na cooperativa e lá, (deram) explicação que tinha que plantar. Disse (o palestrante) que o município já estava multado por desmatamento e que abateria a multa com esses plantios. (Disse que) tinha que tirar a cana (da faixa ciliar) mesmo que fosse $01^{\circ}$ ano (de idade da soqueira)". 
"Deram 2 anos de prazo pra fazer. Em dois anos davam facilidades. Quem não fizesse era multado e faria por conta: viriam com máquina e o dono pagaria".

"Prefeito disse que ia cuidar. Se soubesse vendia essa faixa. Por direito era pra ter indenização". Diz que não pôde aproveitar nada: "pago imposto... terra perdida".

"Usina taca fogo, se pegar nas árvores a responsabilidade é do dono da terra".

Mandaram arrancar as bananeiras (que existiam)". O irmão dele (proprietário vizinho procurado pelo programa) "tinha fruta e näo buliram. Se (eu) tivesse plantado fruta tinha escapado. Tem muito tatu e raposa que aproveitariam o que cai. (...) Eucalipto tá nos $30 \mathrm{~m}$ e perdeu também; mais de 200 ánores. Disseram que não podia usar as rebrotas, senão machucava as árvores". Disse ainda que pra cortar eucalipto, mesmo fora dos $30 \mathrm{~m}$, "tem que tirar ordem do IBAMA".

"Cultura na beira (do ribeirão) é ruim, mas uma criação daria. E não cortar as nativas. (Teria) capim forte pra não ter erosão e ainda ajudava a gente (do campo)". Não concordam com essa restrição.

"Hoje a terra sem água tem maior valor, o contrário de antes".

Segundo Joaquim: "Não. (Foi) por vontade deles." Mesmo assim não foi contra.

No seu modo de ver, "os mais ricos são mais rígidos", em relação à resistência dos que tinham propriedades maiores, aos plantios.

Foi falado (que o prazo pro plantio era de) 2 anos, senão era processado".

"(Eles do programa) disseram: 'é lei federal' ".

Carlos disse que na reunião foi falado de uma "multa pesadíssima, a ponto até de ter que vender a terra".

Não lembra bem dos nomes, mas assinou um documento se comprometendo, "e se não plantar, 'multa gravissima'. Assinei sozinho (quando do momento da assinatura, sem a presença de outros proprietários); já sabia que precisava concordar. "Eu procuro minha parte e cada um que se vire."

Se fosse pra reflorestar os $800 \mathrm{~m}$ (que possui em comprimento de mata ciliar) e mais a cerca, ai ele acharia ruim.

Cláudio e Roberto dizem que agora concordam com o plantio das árvores; "agora já foi mesmo. Mas é um grande compromisso. Gado, porco, galinha, dizem que não pode. Fogo então nem pensar. É obrigado a replantar". São mais 500 mudas até março: 250 de replantio e 250 pra completar o plantio; este último, motivo da recente multa.

Quando ameaçado, assinou.

A informação correu e gerou medo.

Frente à não aceitação do programa, técnico disse: "não tem como conversar com você", e o ameaçou a ter que conversar com o promotor "caso não quisesse florestar".

Houve uma promessa de campanha do prefeito, onde a prefeitura assumia alguns compromissos relativos aos plantios do programa; prefeitura acabou sendo processada pelo promotor.

Assinou um 'contrato' onde tinham "as obrigações, as combinações". Segundo ele, assinou apenas por que tinha a lei por trás. Trouxe o contrato pra me mostrar e leu o nome CESP: "será que a CESP não era o 'patrão'?"

Pediu à equipe se podia ser plantado banana, e a resposta foi negativa.

"Ronaldo (técnico da equipe) disse: 'Faz que fica bonito"; eu falei: "Faz você na sua terra que fica." O técnico disse ainda, segundo o proprietário: "Você sabe que essa terra não é sua?", ao que ele respondeu: "Engraçado... pra pagar imposto é minha." 
Fica muita irritado com essa questăo da posse: "Vou plantar no que năo é meu? Fazer manutençăo no que năo é meu?"

Desafiou Ronaldo a fazer uma reunião na Cooperativa, e com o advogado, para ver se tinha alguém que era a favor de fazer esse programa.

Nos dois primeiros anos os técnicos passaram lá, depois abandonaram. "Falaram: 'vocé năo é dono da terra (faixa ciliar); é da Marinha." Em resposta a isso eles perguntam: "Quem é o dono desse projeto? Quem é dono dessas árvores? Então o dono (da propriedade) tem que receber dinheiro de quem é o dono (desse projeto). Quem é o patråo?" Dizem que esse patrăo deveria fazer tudo isso bem feito.

Mateus e Gustavo dizem que concordaram com o programa. "Năo gosto de ser contra a lei".

Ele mesmo, Mateus, diz que năo era contra, "desde que voltasse um recurso. Quem só tinha gado ia perder tudo." Acham até que uma pessoa vendeu a propriedade por isso. "Eram até agressivos (os proprietários). Aqui (na propriedade) foi o primeiro (plantio) depois da Cristina. Na segunda reuniăo era obrigado (a aderir), com o promotor, dizendo que tinham multa pelo desmatamento que contava desde aquele tempo. Plantamos já no $1^{\circ}$ ano."

"O papel foi assinado, mas nem foi lido. 0 advogado (presente) era da cooperativa e falou: 'nem falem nada, peguem, assinem e pronto'. Explicou da multa retroativa."

Estevăo também năo aderiu espontaneamente: "Não. Fui obrigado."

"Se é coisa que beneficia você, vocé toma iniciativa. Mas năo vai beneficiar em nada, né?"

Nảo sabe porque está ainda com processo: "Mas tá tudo plantado!". Acha que é por causa da foto (os R\$ 1.200,00), "deve ser. Năo tenho mais área". Ou talvez por causa de seus tanques, sem cobertura florestal em volta.

"Quando saiu o projeto muitos brigaram". Conta que acabou plantando: "Mata pra água é bom".

"(A) terra năo é mais nossa. É terra anulada. Ficou inútil. Não tem mais uso nenhum". Era pasto desde que ele chegou na propriedade. Só tirou o pasto pra colocar árvores. Diminuiu a criaçăo e teve que "colocar pra cima".

Ele năo está de acordo com essa restriçăo: "năo precisava de nada; sempre foi assim e conservou. Năo prejudica nada". Perguntei se era possivel um uso conservacionista: "Sim, com pasto, como estava!".

Entende que a proteção só faz sentido na área da nascente, das nascentes da cabeceira. Diz que essa área é respeitada a muito tempo, que sempre cuidaram muito pra năo descer terra lá. Mas ao longo do córrego, à jusante da cabeceira, até a represa, "năo precisaria ter mata. Se correr (água dessa área pro córrego), é onde a água corre mesmo, năo tem necessidade. É uma burrice!"

"Deviam ter pensado em plantar coisa melhor: abacate, manga e outras de qualidade (frutiferas). Al seria importante. Goiaba. Dal serve pra todos; passarinho come. Plantaram árvores sem qualidade. Tudo porcaria: pára-raia, embaúva. Seria melhor se tivessem plantado fruta. (As próprias pessoas do programa) Disseram que se tivesse plantado frutas, (eles do programa) näo tiravam! (Se soubesse disso antes) Eu mesmo teria plantado laranja!"

Como deveria ter sido feito esse programa? "Pra năo prejudicar, só năo fazendo! Deveria reunir e orientar: 'vamos fazer de tal e tal jeito. Explicar. Fazer uma reuniăo com todos e combinar. Se usou lei pra nós, use pros outros também!" 
Gostaria de ter: "granja, boi em confinamento, ampliar a propriedade. Sempre trabalhei com gado; depois ficou ruim".

"Falta dinheiro. Tirei peixe (do tanque pra vender) e năo posso por mais, por falta de dinheiro."

Leonardo também năo aderiu espontaneamente. Talvez tivesse sido se năo gastasse nada. Tinha que plantar. "Lutar contra a lei é dar murro em ponta de faca".

Năo teria entrado, foi forçado. Depois concordou. Achou boa coisa.

Começou com uma reuniăo dizendo que todos tinham que plantar. Reuniăo na cooperativa, quando prefeitura disse que ia plantar. Começou do outro lado (Roberto, Raquel). Até chegar nele foram 2 anos. Entåo promotor processou.

"[Antonio] levou ao conhecimento do promotor, que disse: 'isso al năo tem nada com a prefeitura. É vocé".

E eles mesmos tiveram que plantar. Deram as mudas e a familia mesmo plantou.

Quando fui procurar o proprietário, falei com seu filho, que mal ouviu as palavras "plantio das árvores" e "Forquilha" e já partiu pro ataque, me aconselhando a fazer pesquisa na cidade pra ver a qualidade do rio. A irritaçăo causada pelo programa, tanto no filho quanto no pai ficou evidente.

Luís disse que teve que entrar no programa porque era lei. Se fosse espontâneo ele é que deveria "escolher onde estava (o plantio) e onde pode (ter lavoura ou criaçăo)". "Se já tinha consultado advogado e gente estudada e disseram que é lei, daí năo tem jeito, năo adianta bater cabeça. $O$ culpado acho que foi o prefeito da cidade: é o que mais manda na cidade!"

"(...) turma de Piracicaba, passaram em 4 e deixou carta, intimando pra ir no escritório em Piracicaba". Marcaram dia pra ver quando iam plantar árvore. O vizinho avisou da "turma da árvore" que ia passar em sua propriedade e convidou pra ir ver junto com ele: 'disse que é obrigado a plantar', avisou o vizinho. Este apresentou o proprietário, e deixaram com ele também uma intimaçăo pra ir a Piracicaba também. Questionou: "por que tenho que ir, já que estou de acordo (com o plantio)?". Entảo năo precisou ir. "Se é lei, e disse que tem que plantar, se a cooperativa disser que tem... por que ir lá?".

Ele foi sozinho na cooperativa, falou "com o advogado da cooperativa, que disse: 'vamos ver o que se pode fazer... De começo vamos concordar. No outro dia chamou um por um, o chefăo das árvore; se năo tivesse de acordo tinha que ir atrás de advogado".

"Aquele terreno foi perdido; que o governo pagassel". Quando compraram "ninguém avisou que era do governo!". "Pagamos pela terra, mas daí eles chegam e obrigam a plantar".

Lucas diz que, praticamente năo foi. Năo atrapalhou mas năo houve programaçăo antecipada. Mas "tive prazos pra fazer, năo posso reclamar".

"Houve convocaçăo pra reuniåo". Esclareceram o que tinha que ser feito. Fizeram os contratos. "Durante a reuniăo avisaram que quem năo fizesse o promotor iria processar. Era lei e era obrigatório".

Receberam o programa (a familia) normalmente; năo acharam que ia prejudicar em nada.

Segundo ele, o pessoal do meio ambiente, DEPRN, disse que pode isentar essa (área), mas ele acha que năo compensa ir atrás dessa isençăo. 
"Deveria ter sido melhor programado, com mais orientaçăo pra fazer bem feito. Aqui foi feito às pressas".

"Foi falado de que ia ser feito trabalho maior de conservaçăo de solo e não veio".

"O promotor deveria orientar. (o plantio da mata ciliar) é como lavoura: precisa de cuidado. Dal que deveria ser programado e ser mais tolerante. Mexer com planta exige isso".

Thais diz que: "Não. Depois que explicaram aderi. Não foi por vontade minha, fiz por obrigaçăo".

O pessoal do SAAE veio avisar que seria obrigatório. Assinaram 0 acordo (de abandono da exploraçăo económica) à medida em que fossem renovando os lotes (últimos cortes da cana antes da renovaçăo).

Raquel diz que sua adesăo foi espontânea. Porque já plantava árvores, nessa linha (eucaliptos) e porque parte dessas áreas ciliares já estavam disponiveis para isso.

Considera difficil minimizar os problemas que surgiram com o programa, porque "no fundo, o agricultor tá perdendo área; perde terra e tá tendo que plantar 'arvrinha', como eles dizem. Perde receita no presente". Sugere a desapropriaçăo pelo Estado, porque "o produtor só ficou com os problemas". "Aqui não teve nunca conflito por água", acrescenta.

Segundo Pedro, foi de 'comum acordo'. Teve importância para a imagem da usina, e serviu de exemplo pra outros.

Responsabilidades da usina quanto aos plantios em áreas de fornecedores e arrendadas

Nas primeiras, a responsabilidade é toda do proprietário, embora a usina tenha muito cuidado nas queimadas. Nas segundas, a usina tem responsabilidade na conservaçăo dos plantios. Em nenhuma delas se responsabiliza em plantar.

\section{2c) Manutenção e replantio}

"Pediram pra capinar. Sem ganhar nada! Tá estorvando e ainda tem que cuidar!" "Deram 2 anos de prazo pra fazer. Em dois anos davam facilidades. Quem năo fizesse era multado e faria por conta: viriam com máquina e o dono pagaria".

"Queriam que adubasse, por conta (do proprietário), ainda!". (José e Ana)

Carlos fazia a capina, trabalho equivalente a 4 ou 5 dias/homem (um homem trabalhando de 4 a 5 dias). Fazia também a 'coroa' (coroamento das mudas), que ocupava 1 dia/homem. Fez o coroamento por 4 vezes. Somando todo o trabalho, estima em \pm 20 dias/homem de serviço por ano, mas precisou dessa carga de trabalho duas vezes no primeiro ano.

Cláudio diz que teve que pedir licença pra replantar. Acha que dos 28 proprietários, todos eståo precisando replantar.

Mateus disse que ele mesmo buscou as mudas; outras o Antonio (técnico do programa) trouxe. O replante foi dificil devido ao porco (do vizinho, criado solto). "Nåo tenho como segurar o chorume do porco, na enxurrada. O 'afoita-cavalo' ia bem na beira." 
Levantam a dificuldade de combater o fogo (potencial, nos plantios). "Conversamo com a Sandra e o Evandro, e fizemo um acordo oral (sobre a colaboração na manutenção dos plantios), agora vem outro..."

"Carpi 4 vezes, adubei, fiz coroa, 'aguei' com balde". Estevão fazia, ele mesmo com o filho e empregados. Estima que cada capina ocupe \pm 3 meses de serviço pra 1 pessoa, já incluindo tudo nisso, inclusive a construção de cercas.

Diz que fizeram o que puderam, mas não tratou como lavoura: "É como uma lavoura: tem que tratar todo dia, adubar, etc. (Mas) Se já com a lavoura tamo falindo, imagina... (com as árvores). (A gente) Planta, mas não consegue tratar direito."

Replantio ele fez, mas não muito. "Morria, pela qualidade da árvore. Planta em terra bruta, no brejo?".

Leonardo teve que carpir diversas vezes e replantar de 3 a 4 vezes. "Foram 5000 árvores. Na primeira vez morreram 2000. Fracas? Chuva? Não sei. Depois tive que replantar mais 2000, e depois ainda mais algumas. Agora tá bonito".

Tinha tudo em pasto (gado e búfalo). O filho carpe em volta até hoje (coroamento). "O capim vem direto".

"E se pegar fogo lá?" Ele que corre o risco e tem que dar cobertura.

Luís roçava com trator; passava com trator em $3 \mathrm{~m}$ de rua e $(3 \mathrm{~m})$ de pé. $\mathrm{O}$ trator entrava. O terreno dele era mais plano e dava. "No começo dava". Até hoje põe veneno pra formiga. Deu um exemplo: tinham os pés de amendoim, que eram muito fracos e ele cuidou (colocou tutores, roçou) e por isso saiu no jornal. Diz que o motivo desse cuidado todo é que "valia a pena zelar, mas fazer uma vez só". "Replantio, só uma ou outra".

Cuidou das ánores, pôs veneno pras formigas, roçou, tudo..."Quando viram que tava zelando, já largaram mão e não voltaram".

Diz que se nāo cuidasse dos plantios tinha que ir pro advogado; "o custo era menor topando".

Em uma área, Lucas não fez manutenção. Limpa de vez em quando uma outra que tem muito capim. Usa a mão-de-obra da propriedade, sem prejuízo em nada.

"No replantio foi o mesmo esquema do plantio".

Thaís "(vinha fazendo, mas) esse ano falhou (por estar passando por dificuldades econômicas)".

Raquel precisou de muita manutenção. Áreas com mais mato (colonião) precisavam de algumas soluçőes como herbicida. O custo foi absurdo. O capim cresce muito rápido e o serviço não rende (principalmente no verão). $O$ custo é alto. Alguns lugares permitiam a mecanização, mas a maioria não (nas primeiras áreas dava pra roçar com máquina).

Pedro diz que daria pra ter entrado o trator, pelo espaçamento, mas o acesso era muito ruim. Usaram capina manual, com mão-de-obra própria. Deslocavam o pessoal que no período estava mais ou menos ocioso devido à algum contratempo, como chuva.

As roçadas foram feitas anualmente (1 por ano) ao longo de 5 anos, mais ou menos, sem inconvenientes à usina devido ao uso de sua mão-de-obra. 


\section{2d) Legislação e sua influência na adesão ao programa}

José disse que pediu pra reflorestarem só uma vertente, só com $30 \mathrm{~m}$, mas não aceitaram. "Pediram pra (eu) fazer cerca, mas não aceitei por que não tinha criação. Eles queriam pra que não entrasse caminhão".

Segundo Joaquim, se não tivesse a lei "ninguém tinha feito. O sitiante faz como quer, da cabeça dele".

Carlos acha que "É até bom (ter essa lei)." Acha que não atrapalha, "desde que não use pasto, senão ia ficar caro."

"Em 92 a convivência era boa entre os vizinhos. Mas o vizinho ruim foi a lei que apareceu aqui. É muito bronca e näo teve quem mexesse com ela. A lei nos prejudicou. Concordo que precisa do verde." (Cláudio)

Cláudio disse que a multa que ele iria ter que pagar, no começo era de '400.000 fiesp, ufir' (não sabe ao certo), que valeriam hoje $\pm R \$ 50.000$. Uma vez convertidos em 'pés de planta' resultaram em 500 árvores. "O advogado da Associação, da Cooperativa é que deveria ter feito (alguma coisa). Fez nada! Disse que não podia ir contra lei federal."

"Um grande advogado da região, com interesse politico (eleitoral), bom, também desistiu (de questionar a obrigatoriedade dos plantios). Até ele!"

Mateus disse que teria participado do programa, mesmo se não tivesse a lei. "Poderiam ter deixado algumas alternativas", mas complementa dizendo que haveria o conflito com as diferentes atividades dos proprietários.

A respeito de esclarecimentos sobre a legislação, Estevão disse que não houve nenhum. "Carlos explicou que era a lei. Plantei por isso. Sabia mais ou menos pela TV." Mas ele diz que sabe que não tem necessidade (dos plantios).

Queria aproveitar a terra, como antes. "Não ajuda em nada". Acha que (essa lei) não é boa pra ele.

"Se tivesse desmatado, sabia que tava errado. Mas já não tinha! Se tivesse, e tira, aí vai desbarrancando. Aí não é certo!"

"No rio é lei". Mas no tanque que ele fez não acha justo ter $30 \mathrm{~m}$. As árvores contribuíram, "mas pode ir pra $10 \mathrm{~m}$ que é suficiente. (...) Quem deveria ter plantado é a prefeitura; o Consórcio não é de prefeituras?"

"Deveria existir acordo sobre o lugar do plantio: uns pra plantar mais e outros pra plantar menos; 30 m nuns e menos em outros. Deveria reunir e discutir, planejar junto, em cooperação. Os antigos falavam 'natureza traz saúde'. Tem que ter, mas no lugar certo". (Luís)

Thais agora acha boa. "Acho que tem que ter mesmo".

"Essa legislação irritava muito as pessoas: 'aqui tem que fazer, já na outra água (microbacia vizinha) não tem!'. Gerou muita revolta. (...) (A legislação) é feita por pessoas sem muita noção do dia-a-dia da agricultura. Sonham com uma realidade que 
não parte do contexto do pais, nessa etapa de desenvolvimento". Considera que vivemos um conflito de prioridades; fome e educação (dá como exemplo) são muito mais importantes: "não adianta ter água e não ter povo". (Raquel)

Pedro acha válida mas "teria que abranger todos, porque uns fazem e outros não". Acha que os pequenos não fizeram. "Ela (a legislação) tem que ter trabalho não só de multa mas também de conscientização, a pessoa tem que saber o porque das coisas e concordar. Não por obrigação".

Acha que foi bem aceito (o plantio) e bem explicado, ouviu dizer que ninguém foi contra.

\section{2e) Custo total do reflorestamento ao proprietário}

"Foi pouco: duas vacas, pasto, madeira do eucalipto, tanques; pegou terra da cana.(...) Pegou faixa de quase 1 alq. (...) Lote de $10 \times 25 \mathrm{~m}$ na cidade é um dinheirão, e nós perdemo um". (José e Ana)

Cláudio diz que o custo de advogado (da Cooperativa): $R \$ 700+R \$ 500+R \$ 500+$ $\mathrm{R} \$ 500$, segundo ele, em diferentes etapas em que esteve envolvido com processo, "só pro advogado pegar a causa. Se fosse particular ficava entre 5 e $20 \%$ do valor do caso (o que o levou a não procurar tal serviço, tendo em mente a cifra de $\mathrm{R} \$ 50.000$ citada anteriormente). Lembra também da burocracia em que esteve envolvido, "idas e voltas" à cooperativa (contabilizou 12 viagens de carro pra legalizar a situação), tomando seu tempo de serviço.

Custo do perito (o próprio Carlos, que além de autônomo contratado pelo Consórcio é perito do promotor de Capivari): R\$200

Em relação à faixa de terra agora destinada aos plantios: "o que perdi não tem preço, é herança".

"Perdemo ou o serviço (do dia-a-dia) ou o sossego", com o programa.

Mateus calcula algo em tomo de $\mathrm{R} \$ 1000$, só de trabalho (tiveram que plantar 3000 mudas). Deixaram de ganhar o equivalente a 200 ton de cana (que segundo o proprietário valeriam $\mathrm{R} \$ \mathbf{5 0 0 0 / \text { ano). }}$

Segundo Estevão, ele que teve que pagar: mourão, arame. "Quem tem cana não precisa".

Quando vão pro fórum, por causa desses processos, têm que pagar taxa. A última custou R\$ 100,00.

Teve o problema das fotografias, depois das árvores estarem plantadas. Disse que tal levantamento fotográfico custaria $\mathrm{R} \$ 1.200,00$ pra fazer sua área. Ele não tinha o dinheiro. Foi chamado no Fórum, e explicou a dificuldade ao promotor. $O$ promotor quis parcelar. A foto do começo não foi cobrada.

Estima um custo total de $\mathrm{R} \$ 4.000,00$, já com dia de trabalho. "Agora não tem mais custo".

Leonardo diz que teve que pegar muita gente pra capina e replantio. Plantava tomate e pegou o pessoal.

Avalia um custo total por volta de R\$5000. 
Luis teve que desmanchar cerca $( \pm 100 \mathrm{~m})$. Foram preciso 3 roçadas antes de plantar. Teve que buscar as mudas na cidade (uma vez só). Mais 3 roçadas de trator, e a cada 2, 3 meses põe mirex (não gasta muito, em dinheiro).

Lucas considera o custo pequeno: usou trator, óleo, mão-de-obra pouca. Nem o que deixou de ganhar é significativo.

Thaís não tem essa estimativa. Mas o perito do promotor (o mesmo Antonio, a serviço do programa) cobrou $R \$ 500,00$ a última visita.

Raquel não falou de seus custos, mas entende que perder terra, para o pequeno é complicado (a \% de área é alta).

Pedro, da IASF, não soube dizer, mas considera que não foi significativa a área perdida.

\section{2f) Imagem dos proprietários frente à comunidade}

"Tiram sarro, ou indignados: 'por que pagam imposto'?" (José)

"(As pessoas da cidade) acham que vão ser beneficiadas, que vai aumentar a água"; mas Cláudio não acredita; pensa que é exatamente o contrário.

"A turma da cidade acha bonito - a pessoa 'cidadã', sem vínculo com o campo- , e outros ficam do lado dos proprietários. Várias opiniöes. (Tem) gente que entende." (Mateus)

"O comentário era de que (o programa nos) prejudicava. A maioria fica de boca calada. Não tem pra quem reclamar." (Estevão)

Luís nos contou que alguns da própria região o chamaram de bobo, "mas eles que tá com processo, e nóis tá livre!". "Os da cidade elogiavam, (porque eram) os que não tinham que plantar. Diziam que iam voltar a pescar no quintal de casa, em Capivari (pensando na recuperação do rio Capivari, pelo programa desenvolvido no Forquilha)".

"Vêem como os culpados, até pela queima da cana". Lucas tem a visão de que "foi muito fácil fazer aqui (por não terem reagido contra); os 'burro manso' somos nós!

"Nós aqui somos os criminosos mas (a opinião pública) não vê o que os outros fazem na cidade. Se finalidade é proteger o rio o grande causador (da degradação) é a cidade".

Em reunião realizada recentemente com secretário da agricultura de SP (ele não está bem certo do cargo desempenhado pelo palestrante) na Associação, foram provocados a questionar a imagem de degradadores que a sociedade têm deles. "A cana (principal atividade agrícola da região) vem dando lucro para o país; as opçöes para diversificar são poucas: uva tá ruim, milho é ruim na região; pêssego vem caindo preço. Pouca opção". Ele arou a 20 anos atrás pra implantar pasto, depois quase que não mexe mais na terra.

"Como o agricultor pode saber se a cana degrada (o ambiente) ou não? Não tem acesso a esse tipo de coisa". 
Raquel diz que em 91 era uma realidade. Hoje é totalmente distinta. Se não tivessem feito esse programa, segundo ela, já estariam atrasados. Ele está ligado inclusive às importações, como um termômetro do manejo que se faz ali. Isso põe a região em posição de liderança; "contribuiu muito pra imagem da Associação". Não pôde, portanto, ser contrária a esse programa. Mas há muito o que fazer ainda, junto aos proprietários, diz ela. Conseguiram até prazo pra retirada da cana, aproveitando o número restante de cortes.

\section{A leitura dos proprietários sobre o ambiente e seu manejo}

\section{3a) Modo de proteção da mata ciliar e verificação prática}

"Disseram que era pra aumentar a água, diminuir a erosão. Despoluir o rio..."; mas José acha que "não despolui nada. Surgiu a braquiária tóxica; se tira a criação ela vem e fecha a água". Ele acredita que as folhas das árvores caindo no ribeirão poluem mais, e diz conhecer casos em que a água diminuiu, com o crescimento de mato e árvores em volta.

"Cana segura muito mais o solo que cereal, por causa das raizes; e mexe no solo uma vez só (se refere às várias brotações da soqueira, antes da reforma do canavial). Proprietário pequeno não tem força pra tratar fundo a terra. Precisa de máquina. Quanto mais fundo (profundidade da camada revolvida de solo), mais segura água. Com o burro (a profundidade trabalhada) era $\pm 20 \mathrm{~cm}$, qualquer chuva leva tudo; 0 chão é muito duro."

Sobre o programa dos plantios: "Falaram que era pra não poluir a água, e pra aumentar a água. Mandaram fazer curva de nivel. A água é toda levada pro ribeirão; em uma noite só, soterrou o tanque. Acontecia mesmo e foi bom terem falado: tem que fazer bem feito (os terraços, curvas de nivel) senão é pior (do que se não tivesse)!"

"Tanque em cima é mais dificil de parar água, dai gasta mais água, mais motor (a respeito da proibição de se fazer o tanque em seu próprio vale). Não causaria problema algum, sem poluição nenhuma (caso fosse feito no vale)".

"O cascudo faz buraco no tanque".

Lembra com saudades do BHC: "BHC era pra praga. Usava também na criação, pra carrapato, piolho...pulverizava".

"Parou porque era muito tóxico (pra quem manejava); não causava problema na água".

"(Eles do programa) disseram: 'é lei federal'; que podia melhorar a água. Que podia aumentar a quantidade de água". Joaquim diz que não percebeu aumento algum até agora.

"Serve pra passarinho criar, segura terra. Se vai terra, não atrapalha o ribeirão lá embaixo. Lá não vai terra." (Carlos). Quanto à colaboração da cana na conservação do solo: "É a lavoura que mais ajuda a terra. Pela raiz, até segura mais (a terra). Na cana, bem pouca água corre. Com cereal (citou o feijão) vai mais (terra, na erosão)."

Cláudio não sabe. "Árvores longe (do ribeirão), capim perto e fechando o ribeirão, e abaixa a água", diz desconfiado da eficácia dos plantios.

Cana é raiz muito resistente, conserva ainda mais (o solo, da erosão)". 
Comentou sobre o problema do desemprego que virá com o corte mecânico da cana e questionou as justificativas ambientais dessa ação: "cana polui muito menos que fábrica. O fogo favorece $100 \%$ a lavoura", explicando que eles não poderiam deixar de queimá-la.

"Evita carrear terra de cima, filtra a terra. Mas braquiária já é suficiente pra segurar (observavam isso acontecendo na propriedade). Arar isso (esta faixa onde está a mata ciliar) não está certo, nem pra plantar árvores." (Mateus)

"Raiz segura, não deixa descer erosão. Pro rio é bom, não é ruim". (Estevão)

"Cresceu o capim (na beira do córrego) depois (dos plantios). Capim já segurava antes.(...) Mata pra água é bom". Já no assunto dos plantios: "É área que não vai servir pra nada. É área que vai ficar inútil. Só vai segurar a terra melhor. Pode melhorar pro futuro, na nascente apenas. Pode ser até que aumente a água no futuro."

Leonardo não acredita que protege os cursos d'água. Quanto mais árvores tiver é melhor, mas não pra proteger. "No rio é lei". Mas no tanque que ele fez não acha justo ter $30 \mathrm{~m}$. As árvores contribuiram, "mas pode ir pra $10 \mathrm{~m}$ que é suficiente".

"O que pode atrapalhar a água é a erosão, e a mata ajuda nisso. Mas tendo pasto e curva de nivel já resolve; no pasto a água não corre e se correr ela é limpa". (Luis). Ele acha importante: "tem lugar que ela é importante, tem lugar que ela atrapalha, onde vai feijão, arroz, cana, milho". Ele tem 'mato' na propriedade e "queria poder usar mais (a área, pra lavoura)". "Onde o chão é torto (barroca) tudo bem".

"Melhora o teor e a capacidade (volume de água).(...) Ela segura a terra"; Lucas diz observar isso na propriedade.

$\mathrm{Na}$ área onde hoje é o tanque, quando chovia o terreno encharcava demais pra cultura, e na seca, secava muito o solo (solo ruim pro cultivo). Acha hoje que é "excelente coisa, assim como o terraço", porque depende da água, e não vai querer sujá-la.

A área que perde não faz diferença, diz ele. É "como um investimento".

Não tem outra idéia, "tem que ter esse mato que vem em volta (do recurso hídrico). Já um pomar teria que limpar (ele pensa em colocar frutiferas na beira da APP)".

Thais diz que a mata atua na erosão, "retém a água". Não sabe muito, não observa muito, por estar longe da represa.

"Ela funciona de várias maneiras: área em volta (dos corpos d'água) sem sólidos (desestruturados), menor volume de assoreamento, fauna..."; Raquel brigou por frutiferas...não tinha (deu o exemplo da amora). "Pessoal proibe de plantar mangueira, goiabeira, jabuticaba (sua mãe já se preocupa com invasões na propriedade para pegar as frutas), ou até outra coisa que pudesse ter uma receita...podia ter feito outra coisa". Sente que as coisas poderiam estar ligadas, "eles não têm visão do ser humano. Pessoal da roça caça pra comer". Se diz "lutadora do meio ambiente, mas em $1^{\circ}$ lugar, preservar o ser humano. Dei creche, dei condições para o ser humano." Se ele precisa de proteina, é favorável à liberação da caça (nesse contexto) da capivara, de pombas (ambas em desequilibrio populacional em algumas regiões do estado, prejudicando as lavouras). 
Raquel acha que a mata ciliar é importante. Proteções, embelezamento, refúgio de animais.

Para Pedro, o modo de proteção aos cursos d'água seria evitando o assoreamento, como uma espécie de barreira. Isso tem sido observado em sua prática profissional.

\section{3b) Mata nativa e a fauna}

"Capivara só estraga: o arroz, come tudo! Tem vários passarinhos que estraga. 0 quero-quero estraga a roça de milho (quando ela está no ponto que precisa) pra fazer o curau". (José e Ana). Acham que a mata ciliar é boa: "cria a passarinhada e ficou bonito. Mas pra quem tem pouca (terra) prejudica. Lucro não dá pra ninguém, só prejuizo. Se fosse fruta, o passarinho comia, mas só (plantaram) essas árvore que não vale nada: sangra-d'água e 'taxipingui', dá muita praga e cai cedo, logo que é arvinha". Uma sugestão que José dá é de que o capim é bom para os $30 \mathrm{~m}$, solta a criação e ela mantém. Outra é a de não cortar o que tem. Conclui dizendo que pra eles ali a mata ciliar não serve pra nada.

Depois do plantio fizeram estufa (próxima aos plantios); hoje a sombra e a "raizama" (raizes das árvores invadindo a estufa) formados estão prejudicando a estufa, principalmente a sangra-d'água, cuja raiz ele diz 'brotar' (diz isso por ver muitas plantas pequenas nascendo em volta da árvore).

Sobre a acusação de uso indiscriminado do fogo na região, Joaquim rebate: "Não é verdade"; ele e o irmão Carlos dizem que sempre tiveram cuidado. Discordam também da afirmação de que são feitas derrubadas de matas: "só no passado; mas da década de 50 pra cá, já não tinha."

Carlos fala sobre a mata ciliar: "Fica mais bonito; mais sombra, (e por isso) consome menos água (criando uma área mais úmida)".

Para Cláudio: "É bom ter árvore na beira do rio; sombra pra ficar lá. Se fosse bem feitinho seria bonito. Se todos plantassem e zelassem. Pro ar é bom. Não sei. Gosto de árvore... no lugar certo... onde não se ocupa." Tem lugar onde não ele não quer plantar, e considera esse um lugar ruim pra se plantar.

Dá algumas sugestões: limpar o rio (dragar), plantar bananeira, árvores frutíferas. Tirariam proveito e zelariam. Seria um benefício público. "Não seria mais sua propriedade e poderia doar as frutas pra creches, além do proprietário poder fazer uso, os pássaros. Além do que 'teria o verde'.

"O técnico disse: 'mas isso é mata ciliar, não é pra tirar proveito' ."

Contam uma história (real, segundo eles) de um último lobo guará que apareceu no bairro Boa Vista, a muitos anos atrás, que perseguido por caçadores foi se esconder dentro de uma casa, onde só estava um bebê em seu berço. Ele não foi morto, e por ser um bicho desconhecido do povo da região, todos queriam ir vê-lo no cercado que foi feito pra tal fim; foi dai que o entrevistado o viu. Ao final, acabou sendo vendido pra um circo que estava de passagem por Capivari.

Mateus e Gustavo gostam da mata, se dizem acostumados a ela; nasceram ali. Mas não vêem utilidade. "Na propriedade, tudo com orientação, tudo é aferido." Eles dizem ter cuidado com os produtos. Mas concordam que muitos realmente não fazem isso. 
Lembram, porém, que : "em lavoura, não existe perfeição; o tempo (climático) é muito difícil (no sentido de não poder prever algumas coisas, como chuvas intensas). Todos têm um pouco de árvore no sítio". Na propriedade o solo é bom, não tem erosão; segundo eles, ela ocorre mais em solo de areia.

Sobre o uso indiscriminado do fogo, se justificam lembrando do próprio manejo, onde o fogo é importante. "Em 47 não podia queimar cana, até década de 60 (não tem certeza), quando era o tempo dos franceses (da usina União São Paulo)."

Não concordam com o que se coloca de derrubadas de mata: "Aqui não! Só quando tinha fogão à lenha!"

Para Estevão, a mata: "Muda o ar, purifica." A fauna: "Pra gente não serve pra nada. Pro ambiente também não serve pra nada. Se é tamanduá, come formiga. É bom pra preservar. Pra quem comer, serve".

"O sítio tem bastante capoeira; não serve pra nada. Não é madeira de lei. Serve pra sombra, pra uma criação Se precisa de mourão tem que ser "calipto" ou comprar". Ele avalia que sua terra não é 'proprícia' pra eucalipto, então não planta. Lembrou que a nossa conversa ali, estava acontecendo à sombra de um abacateiro (embora fosse manhã ainda, o sol já estava bem forte).

Luis diz que: "A mata, a floresta, traz saúde, o ar é outro. Num dia de sol quente...tem que ter a sombra. Ela (a mata) é bonita. Em relação ao ribeirão, um amigo me disse que tinha uma carrasqueira (mata) e a água lá vivia sumindo. Dai arrancou tudo e fez tanque, e hoje tem muita água".

$\mathrm{Na}$ propriedade dele "é normal", não reparou. Sobre a mata ele não sabe, "mas eucalipto chupa a água (sua raiz vai muito no fundo), e bananeira aumenta a água! Bambu também diminui (a água)".

Com a cana crua, a palha vai estercar a terra; ele não é contra. Mas que paguem o que vai custar mais caro. Ex: "cobre mais o açúcar e consumidor que berre. Vai tirar do nosso bolso de novo !?". "Se for cortar sem queimar, usina vai cobrar mais ou não vai fazer".

Lucas diz que a mata serve pra segurar erosão também. Sua mata nativa (e a que ele conhece) coincide de ser em barroca também, tendo assim o mesmo efeito da ciliar. "Os passarinhos comem insetos". Quando se parou de caçá-los, o número (de pássaros) aumentou. Não sabia se tinha um inseto/praga específico que os pássaros comiam. Daí lembrou dos gafanhotos e do curuquerê (lagarta), que atacam principalmente sua cana.

Thais gosta da mata. Pelo seu gosto, "queria plantar mais. Gostaria de plantar madeiras nobres".

"Mata tem que ter o lugar dela. Não pode largar árvore no meio do lote de cana. Tem que tirar, mas dai tira uma e planta dez. Mas precisa ter união dessas áreas pra melhor função da fauna, mas deve ter uma lógica (sobre o planejamento dessa união)". (Raquel)

Pedro concorda com a conservação da mata nativa e da fauna: "só traz benefícios". São os últimos e são poucos, valendo mais a pena conservá-los do que pensar em explorar, "para a humanidade". "As que sobraram já estão por ai isoladas, e então é 
burrice mexer lá se não tem retomo financeiro. Considera que existe muita área mal utilizada por aí, não justificando a abertura de novas áreas de mata.

Segundo ele, as matas contribuem na temperatura, umidade, qualidade do ar, como refúgio de animais.

Considera a mata ciliar "fundamental pra própria subsistência da própria água". Ele observa que toda cabeceira é formada por árvores, que as protege. Tem observado lugares onde se retirou essa vegetação, e que a nascente reduziu ou 'se mudou' para outro ponto.

Sobre as queimadas, acha que não causa mal à saúde ou polui. Contribui apenas com pequena porção para a poluição do ar. "Não queimar a cana é mais transtomo (social), maior desemprego". Elas exigem um cuidado maior, como a presença de caminhōes bombeiros e aceiros, que vão de 5 a $10 \mathrm{~m}$.

\section{3c) Nascentes - histórico da conservação}

Na propriedade de Joaquim, a área das nascentes foi abandonada já a muitos anos, tendo hoje uma capoeira alta. Dizem que "o pai gostava de ver sempre a mata. O pessoal mais antigo foi criado com muita mata. Ele deixa ainda hoje porque acha bonito, "tem muito passarinho".

Na de Carlos, diz que "Foi onde foi feito o reflorestamento".

Cláudio conta que eles tinham pés de manga de quase 100 anos que ficavam em uma área de nascente. Essa nascente tinha água em janeiro, e depois, em maio secava. Depois que tiraram as mangueiras, a uns anos atrás, observam que vem mais água dessa mina. Ele e seu tio, Roberto, conhecem caso de uma propriedade onde o dono "reflorestou e depois diminuiu a água".

Mateus diz que tem uma principal, com bastante água. Todas elas estão conservadas, com caixa pra armazenamento; mas antes estavam todas no meio da cana.

Estevão diz ter mais de uma, e têm observado que a água delas 'diminuiu': "Falta de chuva. Já vem de muitos anos. Antigamente o córrego era forte. (Hoje) pra poder ter água tem que represar, todos fazem".

"Elas já tavam com árvores: goiaba, guaiuvira e mata". (Lucas)

Thaís disse que o local da nascente sempre esteve com capim e cana, como é até hoje. É área de brejo (nada vai lá; não tem árvores).

\section{3d) Água - posse e responsabilidade}

Para José e Ana, a água é deles, e a obrigação (de cuidar) também. Disseram que já faziam esses cuidados com a nascente; colocaram manilha de concreto (para acumular a água) e deixavam ela limpa pra quando chovesse. De lá pra cá eles vêm aumentando o reservatório, encaixando mais manilhas. Entendeu por cuidados o trabalho que faz na captação e armazenamento. 
Carlos e Joaquim acham que é de todo mundo. Joaquim, que possui uma área de capoeira diz não ter o que cuidar, "é natural da barroca, de muitos anos".

"De quem usar; é da sociedade. Não tem nem como usar só pra si. Deveria (a sociedade) ajudar a proteger." (Mateus)

"(A água é) de todo mundo". Estevão diz trabalhar com o vizinho (que compartilha com ele essa água) de modo 'cooperado', no uso da água. A responsabilidade seria "de todos que usam".

Ele entende que os tanques, no bairro, não diminuem a água, pelo contrário: "Eles aumentam a água". Diz que encharcariam mais o solo e com isso aumentaria a probabilidade de "brotar água".

"Água passa pela propriedade e é de todo mundo", diz Luís; na propriedade, ele mesmo tem que cuidar.

"Não é totalmente minha"; agora Lucas não acha mais que é dele; considera o direito de usar. Acha que seria do povo da região. "E tem que deixar correr, é beneficio (pra todos)". Mas a água do poço considera dele, pois 'não corre'.

"Cada um (deve) cuidar de sua parte; até o rio Capivari, todos deveriam cuidar. Não adianta campanha em cima do agricultor de onde nasce a água se pra baixo ninguém cuida. Eles que não cuidam pra baixo!"

Thais pensava que era dela, hoje pensa que é do governo. Acha que a responsabilidade é deles, proprietários (que têm água nas suas terras).

Raquel não considera sua a água: "é bem público. A comunidade não colabora, só sacaneia: lava moto, (joga) inseticida, etc". Diz que nunca houve problema (quanto à qualidade da água que chega á Capivari), se orgulha de seu zelo (tem responsabilidade sobre a represa).

Para Pedro, a água é de todos, e a responsabilidade de cuidar é do proprietário em cuja área ela se encontra.

\section{3e) Faixa de mata ciliar - posse e responsabilidade}

"É propriedade (nossa), e a responsabilidade caiu (sobre nós). Prefeito disse que ia cuidar. Se soubesse vendia essa faixa. Por direito era pra ter indenização". Diz que não pôde aproveitar nada: "pago imposto... terra perdida.(...) Usina taca fogo, se pegar nas árvores a responsabilidade é do dono da terra". (José e Ana)

Cláudio nos contou que nos dois primeiros anos os técnicos passaram lá, depois abandonaram. "Falaram: 'você não é dono da terra (faixa ciliar); é da Marinha." Em resposta a isso eles perguntam: "Quem é o dono desse projeto? Quem é dono dessas árvores? Então o dono (da propriedade) tem que receber dinheiro de quem é o dono (desse projeto). Quem é o patrão?" Dizem que esse patrão deveria fazer tudo isso bem feito. 
"Deveria ser do estado; (poderia gerar) mais emprego pra conservá-la, e o indenizado não perderia. (Hoje) a prefeitura é quem cobra (dele, proprietário, os impostos)." (Mateus e Gustavo)

"Faço isso (os plantios) pra melhorar. É pra melhorar água da cidade"; sugere uma indenização: "um valor justo, por que não? Não acha que o governo poderia fazer isso?", afinal, "tô fazendo melhoria na cidade também!"

Mostram-se muito preocupados com o fogo; gostariam de maiores esclarecimentos e segurança. Perguntam sobre o caso de vir fogo de fora, ou de escapar um fogo deles próprios, ou no caso de roubo de madeira e plantas. Acham que essa responsabilidade tem que ser compartilhada, e não deva ser só deles.

"Quando saiu o projeto muitos brigaram". Estevão conta que acabou plantando: "Mata pra água é bom".

"(A) terra não é mais nossa. É terra anulada. Ficou inútil. Não tem mais uso nenhum". Acha que se desapropriasse, eles "punham gente deles, fazem como querem. Lá embaixo (nas áreas próximas à represa), vinham com turma no começo. Como (a minha terra) ficou pro fim, não tive muita ajuda."

Luis não sabe se é dele ou do governo, mas ele zela por ela. "Se o fogo pegar, vou no mesmo dia avisar a 'ecologia' lá". Diz que faz bons aceiros.

"Aquele terreno foi perdido; que o governo pagasse!". Quando compraram "ninguém avisou que era do govemo!". "Pagamos pela terra, mas dai eles chegam e obrigam a plantar".

Hoje, Lucas não considera mais como dele. Pessoal do meio ambiente, DEPRN, disse que pode isentar essa (área), mas ele acha que não compensa ir atrás dessa isenção. "Mas se pegar fogo a responsabilidade é minha!". Pensa que o replantio deva ser responsabilidade dele também.

Para Thaís, os proprietários têm obrigação de cuidar, para a comunidade. Inundaram 5 alq (na represa). Ouviu boatos de indenização. A área foi cedida, não é mais deles, não têm direito sobre ela.

Raquel entende que a posse é dela, "e sempre será. Já que vai ser pro bem comum, seria responsabilidade do municipio".

Para Pedro, essa faixa é do proprietário e o próprio proprietário deve cuidar. Se passasse para o Estado seria pior. Sendo do proprietário e se "fazendo algo que o obrigue a cuidar, é mais interessante" do que ser do Estado.

\section{3f) Utilização de árvores em geral}

"Acho bonito; cerca vento, faz sombra, uma fruta... tem variedade que tem". (José)

"Árvore vai bem na roça: na barroca pra (segurar a) terra, sombra, frutas - laranja. Beleza em volta da casa, pela sombra. Com cana não tem condição de ter árvore.

"A 25 anos, a madeira vinha da matinha. Só pau seco. Depois que começaram a proibir, usa só gás. Antes era só (fogão) à lenha, a casa." (Joaquim e Carlos) 
Cláudio diz que antigamente usava cipó, madeira, lascas pra mourão, pra casa (era chamada 'barrote', feita de barro e madeira), pro chiqueiro dos porcos. Hoje usa eucalipto.

Se pudesse incluir nos $20 \%$ de reserva legal a área arborizada (natural e plantada) referente à preservação permanente, eles já teriam esse valor, hoje. Portanto, pelo menos $20 \%$ de sua propriedade está arborizada.

"Depende do lugar: na reserva é bonita, protege. Uma, isolada no talhão de cana, estorvando, é ruim; enrosca ferramenta. (Deve-se) colocar em lugar certo." (Mateus)

Leonardo diz gostar na beira da casa, fazendo sombra. Tem mangueira, pinheirinho, eucalipto. Os dois últimos pra enfeitar.

Segundo Luis, esse ano (97) descontou mata (no pagamento do ITR), mas até outro ano pagava (por essas áreas também).

"Pra fruta. Reflorestamento com eucalipto pra madeira pra uso, sempre tem uso na propriedade. Pode até comercializar madeira". (Lucas)

"Se árvore estiver em local adequado, só traz benefícios". Eles têm mangueiras e goiabeiras.

Thaís tem problemas com a fiação elétrica (quedas de força devido aos galhos de árvores, nos ventos e chuvas) e seus trabalhadores vivem querendo cortá-las. Mas não permite; tenta encontrar soluçōes (como rede subterrânea) e mostrar a eles que a prioridade seria da árvore, nesse caso.

Considera a região muito produtiva e próxima de São Paulo, defendendo que as terras daqui são pra produção. Observa em suas viagens (como pela Europa) muita arborização nas estradas de rodagem, "mas de forma organizada, não como nós". Defende um melhor planejamento pra questão do plantio de árvores, zoneando regiōes mais convenientes, e nestas, locais mais adequados. Ficou sabendo dos $20 \%$ (referentes à área de reserva legal) e acha ruim, porque toma muita área.

Pedro (IASF) não tem nada contra, pensa que "elas tem que estar situadas em lugar estratégico: beira de estrada, perto de sedes, beira de pátios (deu o exemplo do pátio de carretas, ao lado do local).

\section{3g) Uso da mata ciliar - sobre a restrição de uso e idéias conservacionistas alternativas}

Segundo José e Ana, eles do programa do plantio "Dizem pra fazer o aceiro na beira das árvores, a ainda tombar a cana mais próxima (passando por cima dela); o que prejudica o corte e a rebrota (prejudica a produção do lote). Se não fizer, vizinho pode denunciar e ai vem multa".

Segundo ele, falou na época desse negócio de fazer uso e preservar ao mesmo tempo, mas o pessoal do plantio disse que não podia, porque polui a água. "Bananeira ao invés de chupar, ela solta água. Aumenta (a quantidade de água). Mandaram arrancar as bananeiras (que existiam)". $O$ irmão dele (proprietário vizinho procurado pelo 
programa) "tinha fruta e não buliram. Se (eu) tivesse plantado fruta tinha escapado. Tem muito tatu e raposa que aproveitariam o que cai".

"Porco só se fosse cimentado, cercado e a água (que sai), pra não poluir represava e regava a plantaçäo".

"Eucalipto tá nos $30 \mathrm{~m}$ e perdeu também; mais de 200 árvores. Disseram que não podia usar as rebrotas, senão machucava as árvores". Disse ainda que pra cortar eucalipto, mesmo fora dos $30 \mathrm{~m}$, "tem que tirar ordem do IBAMA".

"Cultura na beira (do ribeirão) é ruim, mas uma criação daria. E não cortar as nativas. (Teria) capim forte pra não ter erosão e ainda ajudava a gente (do campo)". Não concordam com essa restrição.

Segundo Joaquim, a mata da capoeira, "se for pra usar tem que derrubar, sem derrubar não dá".

Tanto Joaquim quanto Carlos estão de acordo com a restrição de uso dessa faixa destinada à mata ciliar.

Sobre a mata que foi plantada, diz Carlos: "a minha já é pra passarinho usar; comem semente de capim, fruta". Tanto o filho quanto o pai (o entrevistado) não gostam e não permitem que se cace na propriedade.

No começo achou ruim, depois achou bom: "fica bonito".

Carlos acha que essa faixa pode ser menor, de $20 \mathrm{~m}$, onde é mais plano. "Se é mais pênsil pode ser mais." Sugere que ela se adapte ao terreno e ao contorno dos córregos, ribeirões.

Quando perguntei sobre um possivel uso dessa área, Mateus e Gustavo disseram: "criação não daria, fruta não daria; eles (do programa) que escolhem as espécies. A gente queria plantar frutífera, não quiseram. Por exemplo: sangra-d'água não é nativa daqui, uma das poucas (entre as plantadas) que não é."

Acha que "mesmo com criação e capim, ele (o capim) cumpriria a função. Com porco já não daria, ele fuça."

"Largando fica melhor que plantando." Diz ter exemplo prático. "Não precisava tirar criação. Acho que (o plantio) é pra garantir que o agricultor não vai dar corte (na mata)."

"O tanque do Madeira, enquanto era invernada de boi tava bem conservado. Quando usina entrou, soterrou tudo."

Sobre a restrição de uso, estão de acordo. Alterar a metragem, só se fosse pra aumentar.

Estevão conta que era pasto desde que ele chegou na propriedade. Só tirou o pasto pra colocar árvores. Diminuiu a criação e teve que "colocar pra cima". Diz que um corredor pro gado que ficou foi suficiente, por causa dos tanques dos peixes, que "dão conta, pra criação".

Ele não está de acordo com essa restrição: "não precisava de nada; sempre foi assim e conservou. Não prejudica nada". Perguntei se era possivel um uso conservacionista: "Sim, com pasto, como estava!".

Entende que a proteção só faz sentido na área da nascente, das nascentes da cabeceira. Diz que essa área é respeitada a muito tempo, que sempre cuidaram muito pra não descer terra lá. Mas ao longo do córrego, à jusante da cabeceira, até a 
represa, "năo precisaria ter mata. Se correr (água dessa área pro córrego), é onde a água corre mesmo, năo tem necessidade. É uma burrice!"

"30 m é muito. 30 só de um (lado) ou 15 m de cada lado já daria" (Luís). E no pasto, na sua opiniăo, os corredores tinham que ser em maior número.

Em relaçåo a um possível uso conservacionista da mata ciliar, ele descarta a lavoura: "năo dá, muita sombra". Sua idéia é permitir que o gado transite embaixo das árvores. Isso traria, segundo ele, duas vantagens: o gado pegando o capim embaixo das árvores ajudaria no seu crescimento ("forma mais"); evitaria o problema do gado de acumular todo num ponto pra beber água, quando os primeiros sujam a água rapidamente, para os demais.

"Beirando o rio, tem lugar que é bem, faz sombra... năo pode deixar o pals pelado! Ela (a mata ciliar) é boa. No tanque, beirando... tem que ter. Mas tem lugar que dá pra usar e fica seguro. Deveriam escolher lugares diferentes para plantar e estudar locais pra poder fazer lavoura, criaçăo".

Lucas acha que "Nesse sistema năo dá". Acha que poderia ser feito (em outro sistema) com criaçăo: "gramado (pasto) bem feito pra criaçăo. Năo seria prejudicial (aos corpos d'água): água e capim pra criaçăo".

Usar eucalipto: "mais fácil de formar e tira proveito mais rápido que nativa".

Raquel sugere plantar palmito (no caso como o dela, que já os possui em fragmentos na fazenda), năo só o nativo mas os mais rápidos também. Eles tém bastante palmito, que a măe plantou no passado, a partir de apenas 2 individuos. Sua măe teme que o pessoal roube.

Concorda com a restriçăo de uso na faixa ciliar, mas considera que seus objetivos podiam ser igualmente alcançados em $15 \mathrm{~m}$, e de outro modo (quanto à rigidez na proibiçăo de uso). "Ninguém diz se outra (metragem e modelo de plantio) resolve ou năo", criticando os valores que existem na legislaçăo, năo bem justificados. "30 m é empírico. Alguém cismou que é $30 \mathrm{~m}$. Năo tem que ter. Acha que $15 \mathrm{~m}$ é suficiente. "É uma carreira de árvores. Alguns já tinham mata natural".

Outro exemplo: a queima da cana é proibida num raio de $1 \mathrm{~km}$ do centro urbano, mas ela vê coisas diferentes acontecendo (em relaçăo ao carregamento da fuligem): tem que ter norma relacionada ao vento e năo à distância. Mas, segundo ela, o Deputado Fábio Feldman năo admitiria reduzir esse raio, para năo perder seu eleitorado.

Acha que a largura do aceiro pode ser menor; ela própria já utilizou aceiros mais estreitos com sucesso. Diz que variam muito as condiçðes na hora da queimada, valendo muito mais o 'feeling' do queimador do que a largura do aceiro. Levanta o perigo do sistema de cana crua: com a queima convencional da cana, esse procedimento leva de 10 a 30 minutos, enquanto que a palha da cana crua acumulada no solo, se vier a pegar fogo pode demorar até um dia até que se consiga apagar. Isso já aconteceu em Ribeirảo Preto. Acha que esse novo sistema vai elevar o número de incéndios, pois os carreadores săo vias de trânsito pra comunidade; pessoas andando em volta, cigarros, etc.

"Não tem jeito para a usina". (Pedro) 


\section{3h) Impacto das atividades locais na vizinhança}

José acha que nåo existe.

Mateus e Gustavo dizem năo perceber. "Só se for negativa (a influência). Aqui năo tem nada (que possa prejudicar a vizinhança) mas sei do risco que tem. Algumas coisas somos obrigados, como a queima, um herbicida, etc. A cana nåo traz nem só mal, nem só bem. Oxigénio, por exemplo, a cana tá sempre produzindo. Cana é que nem floresta, parece mata; é bem pouco tempo que fica a terra limpa"

"Năo (existe). Cada coisa no seu lugar". (Estevão)

Luis diz que năo faz nada que cause tal impacto, porque năo ia querer encrencar com o vizinho (algo que o prejudicasse). Năo tem interferência. "Com o vizinho tudo bem".

No sentido negativo, Lucas diz que năo tem. Nunca teve problemas com produtos químicos.

No positivo, sim. "Com o tanque solta mais água pra quem tá abaixo". Quando planta tomate em terras arrendadas (vizinhos), a cana deles que vem logo em seguida năo precisa de adubo na implantaçăo.

Para Pedro, esse impacto năo existe, porque tudo em volta é cana também.

\section{3i) Impacto do uso das áreas adjacentes à mata ciliar nos recursos hidricos}

José acha que năo tem. "Cana é até bom pra segurar a terra. E produto (químico que vai nela) é muito pouco, difícil prejudicar. Tomate é mais perigoso: muito veneno e se chove lava tudo".

"Tem cana em volta, mas năo prejudica nem melhora. Mesmo quando renova a cana năo prejudica o ribeirăo. Isso a mais de $\mathbf{5 0}$ anos; nunca cortou (secou) o ribeirăo." (Carlos). Sobre o possível impacto de fertilizantes e herbicidas: "na água năo desce nada. Penetra na terra em 20,30 dias e some. Muito pouco (o que vai pra água), porque fica na terra. Vai pro tanque e nunca ninguém morreu, e bebem a água (de lá)".

"No início chegava terra. Hoje năo (acontece mais). Mas na terra de areia, acontece (ainda)." (Mateus e Gustavo)

Segundo Estevăo: "Não interfere; năo atrapalha em nada." Sobre a possibilidade de carreamento de fertilizantes e corretivos em direção ao córrego, ele acha "até bom, como o esterco, porque favorece a mata. $O$ ribeirăo năo tem o que estragar.

O preparo do solo também năo interfere em nada, "porque tem curva de nível. Sempre desce terra na enxurrada. Vai descendo e entupindo (as curvas). Sempre desce. É por isso mesmo que (se) usa pasto, pra năo ir terra no córrego". Disse que năo ara até embaixo: "deixo pra năo dar erosåo". 
Quanto ao 'veneno': "năo chega de cima até embaixo. Nunca chega. Fica no ar, năo corre, já seca." Mas diz que até pode acontecer: "um pouco sempre desce. $O$ que năo pode é soltar no terreno". Lavradores bem instruídos, segundo ele, pensam: 'por que é que vou envenenar a minha própria água?'.

Para Luís, as atividades nessas áreas podem ter interferencia. "O pasto ajuda. Atrapalha quem planta tomate. A água suja (do manejo da lavoura) de tomate, mata peixe, al atrapalha".

"Tem (impacto). Pra melhor; auxilia mais a mata ciliar na funçăo dela; (evitando) assoreamento, erosåo". (Lucas)

Thaís diz que é tudo cana. Ela acha que pode prejudicar; citou os herbicidas usados nas terras da usinas ou a ela arrendadas: "usina tem que cuidar disso".

Raquel conta que, numa ocasiăo, durante forte chuva, a terra já desceu $700 \mathrm{~m}$, passou a cana e caiu na represa. Isso está ligado à declividade, tipo de solo, etc. "Portanto uma lei maluca de $30 \mathrm{~m}$ năo diz nada". Diz já ter queimado talhăo de cana colado à mata e deu certo.

Pedro acha que o impacto é positivo, "pela conservaçăo do solo que tem, evitando assoreamento do solo". Năo vê nenhum negativo.

\section{3j) Alterações observadas na quantidade e qualidade de água na microbacia, em função do programa}

José acha que depois de 3 anos a partir do plantio, diminuiu a água (na propriedade). Dos seus anos de moleque pra cá, diz que reduziu mais de $50 \%$ das chuvas (em volume de água). "Antes era tanta chuva que tinha que estocar madeira e arroz. Dizem que (a causa dessa mudança) é de tirar mata e do crescimento das cidades".

Joaquim e Carlos năo têm observado nenhuma alteraçăo.

"(As pessoas da cidade) acham que văo ser beneficiadas, que vai aumentar a água"; mas Cláudio năo acredita; pensa que é exatamente o contrário.

"Se vai cuidar (da água aqui no Forquilha) por que jogam esgoto (no Capivari)? Por que pago imposto então?" Citou um lava-carros na beira do rio, na cidade.

"Cana respira, é uma mata; é o 'verde' também. O governo devia aproveitar isso em beneficio do ambiente."

"Cana é como matéria-prima, faz o álcool"; diminui o consumo de petróleo, diminui a poluiçăo do ar e "se reformar a frota de carros (passando pro álcool) aumenta a riqueza e aumenta o emprego!"

Para Mateus e Gustavo, năo teve alteraçăo, ficou como estava (nem quantidade, nem qualidade). 
Para Estevăo, na quantidade: "Mesma coisa. Năo interferiu em nada". Na qualidade: "Năo dá pra perceber nada. Pode ser que melhore daqui a uns tempos quando fechar tudo. (...) Repito: o essencial é na nascente. Depois năo tem nada a ver!" "Năo, é a mesma. Năo existia água na seca (só no tanque); chove, e ai corre (água)." (Leonardo). Quanto à melhoria da qualidade da água, Leonardo năo acredita: "Até agora (as ánores ainda eståo) muito pequenas; algumas de $2 \mathrm{~m}^{n}$.

"Năo dá pra saber. Cré que é a mesma coisa (săo 3 ribeirőes na sua propriedade e um já tinha mata)." (Luis)

"Nada." (Lucas)

"Nada. Existe movimentaçăo (no nível da represa) só quando chove nas cabeceiras." (Raquel)

Pedro năo percebeu nada, na quantidade. Acha que coloraçăo da água mudou, estando mais clara hoje. Antes descia mais terra.

\section{3k) Compreensāo do modelo de plantio adotado e interesse}

José diz que entendeu: espaçadas $2 \mathrm{~m}$ uma da outra, tem que "misturar a qualidade, sendo que uma (qualidade) năo vai e morre. Umas tăo secas".

"Tudo misturado", diz Carlos. Intercalando espécies e intercalando "as que duram mais e as que duram menos, pra ajudar mais as outras (que gostam de sombra)." Disse que - guarantå e a 'perova' gostam mais de sombra. "Jequitibá cresce rápido; paineira é mais rápida." Năo sabe explicar "por qué o ipé năo saiu", umas das que ele tém plantado muito na propriedade.

Cláudio năo entendeu. Năo sabe das 'qualidades' e disse que prefeitura năo tinha tempo pra explicar.

Mateus e Gustavo dizem que entenderam. "Tudo marcado: primária e secundária; umas com durabilidade pouca e outras que formam melhor com sombra:" Foi falado nas reunioes, nos contratos.

"Disseram que morria umas pra vir outras. Acho errado. Tem que plantar qualidade que năo morra. Plantaram intercalado; năo conheço por nome." Estevăo nunca tinha ouvido falar nisso. "Eles năo explicaram melhor; eram empregados (da prefeitura). A gente năo entendia, porque tem que conhecer a qualidade".

Estevăo diz que saberia repetir os plantios, "só que mudaria a qualidade. Essas que morrem, năo plantaria. Só as de qualidade boa". Sobre seu interesse em conhecer tal modelo: "năo interessa".

Leonardo diz que năo entrou em detalhes, năo tinha tempo pra perguntar. Sugeriu ao filho, logo no começo, que colocasse rapidamente leucena e eucalipto.

"Mandaram plantar madeira que năo presta (morre logo), sangra-d'água, mas solta semente". 
Luís entendeu assim: "Era uma que durava pouco e outra que durava mais. A que durava pouco formava mais - e vé isso mesmo, tá saindo mais depressa - e eles tinham pressa de formar", năo sabe dizer o por quê. "Plantaram as que eles quiseram. Perguntei se năo podia plantar fruta, disseram que năo porque 'o que a gente planta é pra passarinho, năo é pra gente andar lá' ".

Lucas diz que năo entendeu. "Eles que deram as mudas e plantaram". Sugeriu frutiferas e năo deixaram.

Thaís diz que entendeu, citando a intercalaçăo de diferentes grupos de espécies.

Raquel disse que sim, entendeu o modelo. No replantio ela mesma desenvolveu os plantios, com mudas da prefeitura.

Sim, Pedro diz que entendeu 'mais ou menos'. ("primárias/secundárias, umas saindo mais rápido e morrendo mais rápido, ajudando as mais lentas").

\section{1) Sugestões para reformulação do programa}

José sugere: "1ْ: năo cortar as nativas; $2^{\circ}$ : plantar capim forte, que feche, pra năo poluir, e permitir alguma criaçăo, só pro gasto - senăo, se for muito, também polui".

"Cedro e erva-de-lagarto eram o que dava por aqui. A sangra-d'água formou rápido, na terra barrenta. Mas ipê, angico, guarantă... é vagaroso e năo vai". Disse que se tivessem deixado pra eles (proprietários) escolherem as espécies teria dado mais certo.

Sobre o interesse em ter madeira na propriedade: "Mas se năo tem mais atividade (agrícola) nem criaçăo (suas 'atividade' e criaçăo estavam concentradas no vale, e foram abandonadas devido ao programa), mata e madeira (de eucalipto) pra quê?"

Diz que implantou o projeto. Algumas morreram com geada e ele replantou por conta.

Joaquim diz como deveria ter sido feito esse programa: "Abandonava (a faixa) e deixava vir regeneraçăo. É só năo ter pressa. Em 20 anos forma. A qualidade do que vem é diferente em cada lugar. Nas (áreas) de areia, já vem as mais adaptadas. $O$ pior é pra quem tem pasto. E se năo cercar, o gado destrói, năo tem jeito."

"No lado de cá, a terra é de qualidade boa." Carlos acha que "lá na terra (dos plantios), muita planta năo vai"; observa que quando a terra é de "qualidade alta" o que vem bem é a embira-de-sapo, a lixa, o pau-d'alho. Quando é de "qualidade baixa, mais arenosa", o 'caxipingui' e o cambará gostam.

"Se fosse arboredo (bosqueado) ficava bonito."

"Talvez a umidade ajude (no crescimento das árvores), com o capim", diz o entrevistado, questionando o combate ao capim, motivado pela alta carga de trabalho que experimentou na manutençảo dos plantios e pela conhecimento da regeneraçăo natural da propriedade vizinha, de seu irmåo.

Sugestőes do Cláudio: "Pőe gado com árvore. E alta vigilância (cuidados, precauçőes) sobre o porco, porque se chover desce terra". 
Segundo ele "deve-se preparar a terra pra ter condição de plantio; não é só pelar a terra e por planta". Frente ao impasse de quem cuidaria desse preparo prévio da terra, a técnica teria dito pra ele "plantar à foice" mesmo, roçar apenas e abrir as covas.

Pensam que se a prefeitura é interessada e vai se beneficiar de algum modo, deve contribuir com os proprietários. Por fim, diz irritado o tio, Roberto: "Quem é o patråo desse programa?!".

Sugerem remuneração pra quem assumisse responsabilidades: "indenizar a terra que perdeu; plantava ganhando; quem cuidasse, na vigilância, ganhava. Responsabilidade, ganhando!"

Dizem que não há clareza de quem seja o 'patrảo' e não tem beneficios, a participação num programa como esse: 'Vai pegar um compromisso; vai ter que cuidar e não sabe pra quem vai beneficiar". Diz que um financiamento do govemo pra lavoura já seria um beneficio.

"Igual (foi), mas com incentivos. Mas eles vão falar da 'culpa' pelo desmatamento de 50 anos atrás." (Mateus e Gustavo)

Para Estevão: "O pessoal do programa deveria dar incentivo. Ajudar mais. Ninguém tem condição de fazer sozinho. Govemo deveria até pagar pra (gente) poder tratar bem dessa coisa. Deviam dar incentivo."

"Deviam ter pensado em plantar coisa melhor: abacate, manga e outras de qualidade (frutfferas). Aí seria importante. Goiaba. Daí serve pra todos; passarinho come. Plantaram árvores sem qualidade. Tudo porcaria: pára-raia, embaúva. Seria melhor se tivessem plantado fruta. (As próprias pessoas do programa) Disseram que se tivesse plantado frutas, (eles do programa) não tiravam! (Se soubesse disso antes) Eu mesmo teria plantado laranja!"

Como deveria ter sido feito esse programa? "Pra não prejudicar, só não fazendo! Deveria reunir e orientar: 'vamos fazer de tal e tal jeito. Explicar. Fazer uma reuniåo com todos e combinar. Se usou lei pra nós, use pros outros também!"

Sobre a manutenção dos plantios: "É como uma lavoura: tem que tratar todo dia, adubar, etc. (Mas) Se já com a lavoura tamo falindo, imagina... (com as árvores). (A gente) Planta, mas não consegue tratar direito."

Replantio ele fez, mas não muito. "Morria, pela qualidade da árvore. Planta em terra bruta, no brejo?".

A sugestão de Leonardo é poder soltar o gado por baixo das árvores, e o gado na beira do tanque. "O pessoal do programa pensa só neles, e o pessoal que vive na roça, com dificuldade, tem que fazer (os plantios)". "O cara da roça gosta de aproveitar tudo, planta árvores perto da casa, pra sombra, uma fruta, uma cervejinha...".

Luís gostaria que - agora que formou - pudesse soltar a criação, onde tem luz ainda: "no brejo não vai, não adianta". Ele diz que avisou a equipe: cava $20 \mathrm{~cm}$ já é água. "E não tem nada mesmo hoje lá. Mas o capim forma!"

"Deveria ter sido melhor programado, com mais orientação pra fazer bem feito. Aqui foi feito às pressas.(...) Foi falado de que ia ser feito trabalho maior de conservação de solo e nåo veio.(...) 0 promotor deveria orientar. (o plantio da mata ciliar) é como lavoura: precisa de cuidado. Dal que deveria ser programado e ser mais tolerante. Mexer com planta exige isso". (Lucas) 
Thals gostaria de plantar em espaçamento mais largo pra facilitar a entrada de máquina (pras roçadas) e năo deixaram. "Dal só na capina manual".

Raquel considera difficil minimizar os problemas que surgiram com o programa, porque "no fundo, o agricultor tá perdendo área; perde terra e tá tendo que plantar 'arvrinha', como eles dizem. Perde receita no presente". Sugere a desapropriaçăo pelo Estado, porque "o produtor só ficou com os problemas". "Aqui năo teve nunca conflito por água", acrescenta.

Pedro (IASF) năo tem sugestőes, "foi bom".

\section{3m) O modo de pensar e o comportamento após o programa}

"Passarinho tem mais, hoje. E raiz (das árvores plantadas) vem vindo cada vez mais, tem que ir cortando. As coisas mudaram pra pior.(...)Ajuda um e atrapalha outro". Atualmente ele diz que "năo pode deixar vir mata (na propriedade), senăo năo pode cortar (depois). (...) Estragou a terra até pra vender." (José)

Carlos disse ter aumentado o cuidado, devido à maior responsabilidade, por causa da queima da cana próxima aos plantios. Segundo ele, sempre teve cuidado, mas hoje é maior.

Perguntei a Cláudio se seu modo de pensar mudou após o programa: "Mudou: vi o ruim que é! (...) Em 92 a convivência era boa entre os vizinhos. Mas o vizinho ruim foi a lei que apareceu aqui. É muito bronca e năo teve quem mexesse com ela. A lei nos prejudicou. Concordo que precisa do verde."

Mateus já pensava sobre isso. Via o desmatamento pela TV e já năo achava certo. Pensa no uso do papel, da madeira. "O fogo destrói o mundo. Onde junta palha a terra fica melhor, aumenta a produçăo. Onde năo (junta), terra clara, fraca."

Estevăo entende que, já que plantou, é capaz de melhorar o ambiente daqui pra frente: "faz sombra, protege melhor. Foi ruim perder aquela área, mas acho que năo é ruim. No inicio năo tinha vontade. (...) O jeito de pensar năo mudou em nada. (...) [Antonio] explicou que era a lei. Plantei por isso. Sabia mais ou menos pela TV." Mas ele diz que sabe que năo tem necessidade (dos plantios).

Estevăo queria aproveitar a terra, como antes. "Năo ajuda em nada". Acha que (essa lei) năo é boa pra ele. "Se tivesse desmatado, sabia que tava errado. Mas já năo tinha! Se tivesse, e tira, al vai desbarrancando. Al năo é certo!"

Para Leonardo, nada mudou. Diz que ficou até pior. Perdeu $2 \mathrm{~km}$ de cerca nessa faixa de $30 \mathrm{~m}$, que separava o pasto das barrocas. Nas barrocas plantava milho, mas o que ia melhor era o capim.

"Quando surgiu parecia ruim, depois acostuma". (Luís) 
Lucas responde: "Sim, reforçou a conservaçăo. Acho que a conservaçăo em volta é muito mais importante do que a mata (ciliar) em si (em termos de conservaçăo do recurso hídrico). E isso năo depende só deles (do programa); mais do que a usina faz e mesmo assim estoura terraço, com tromba d'água".

"Foi feito tudo e o rio continua como está; Capivari em época de secas fede".

"Nós aqui somos os criminosos mas (a opiniăo pública) năo vé o que os outros fazem na cidade. Se finalidade é proteger o rio o grande causador (da degradaçăo) é a cidade".

Raquel diz que não mudou seu modo de pensar, este já existia. Veio pra ajudar a divulgar a idéia, que como associaçăo, ela já pensava. Hoje a associaçăo tem viveiro de apoio pra quem quiser plantar eucalipto.

Sobre a represa, diz que tem várias críticas à prefeitura. As reclamaçőes dela e da Sandra eram constantes (parece que passaram por al 3 prefeitos: Zé Carlos, Vadinho e 0 atual, Zico). A água que sai da represa é desperdiçada em Capivari: à meia-noite, as caixas (de armazenamento da prefeitura e residenciais) săo enchidas e o restante "joga fora". Existem ainda trincas na represa. "As taboas văo grudando no dique do tanque e prefeitura năo faz nada (săo naturais e descem na boca da represa)". Ameaçou a prefeitura de colocar fato na midia e al ela resolveu o problema: "a única coisa que brasileiro entende é ameaça, por isso avalia que trabalho do Consórcio foi fantástico". Diz que existem pessoas "sem espirito de luta, mas que adora tesourar.e falar mal".

Raquel contou que existe um projeto na prefeitura, do SAAE (Serviço Autónomo de Água e Esgoto) passar pra SABESP. Ela năo quer vender a terra concedida pra represa; pensa em proposta de comodato em serviços, por exemplo, uma delas seria o compromisso da prefeitura em tratar todo o esgoto de sua propriedade. Com a fiscalizaçăo da prefeitura, faria turismo e pesca na represa.

Ela aguarda resultado do trabalho do IPT sobre o nivel de assoreamento da represa, mas já adianta que é baixo. "IPT vai dizer; se houve assoreamento a culpa é do SAAE que năo usou o 'tira-lodo' (local próprio para tirar esse material, de responsabilidade da prefeitura).

Sobre a cana, diz que a cultura é o maior conservador do solo que existe. Se năo fosse ela năo tinha mais solo aqui, nem no nordeste: mexe o solo apenas a cada 5 anos, forma terraços naturais com suas raizes, e promove excelente cobertura (contra os impactos diretos da chuva). Com grăos, revolve solo de 3 em 3 meses. Acabaria com 0 solo se ela não fizesse o plantio direto. "O arado é o maior inimigo do solo".

Sobre a mecanização do corte da cana, diz que viriam de todo jeito para a usina, seja por questőes ambientais ou económicas, mas viria em velocidade menor, e daria tempo pra resolver o problema da măo-de-obra. Na Argentina já acabou a queima da cana, mas foi um processo mais bem planejado. Por exemplo, "por que năo se desenvolvem máquinas pequenas adaptadas ao relevo mais acidentado?", pergunta.

Sobre a poluiçăo vinda da queima da cana: se dissessem a ela que vai andar de carroça, al ela acredita na reduçăo da poluiçăo do ar. A queima da cana libera as fagulhas, que săo particulados grandes; argumenta que se analisarmos todo o ciclo da cana veremos que esse dano é mais que compensado (pelos benefícios de conservaçăo do solo, da água e fixaçăo de $\mathrm{CO} 2$ ). Não se pode analisar uma fase só.

Pedro diz que "A gente se sentiu útil em relação ao bem causado ao meio ambiente". A usina (IASF) já teve 3 donos; 0 anterior construiu na época 5 açudes ao longo das 
áreas da usina, para "aumentar a água, aumentar a vida" no local, "em quantidade, volume e área verde".

\section{Sobre as motivações e sonhos dos proprietários}

\section{4a) Gosto por outra atividade económica}

"Se năo fosse esse negócio de ecologia, gostaria de fazer tanques pra criar peixe". (José e Ana)

Para Carlos, o sonho é a própria granja de frango, que vem tentando implantar, a dificuldade está na fase atual, em que enfrenta problemas trabalhistas, reclama que é muita "dor de cabeça". Gostaria de ter boi (a limitaçăo é pasto), algodăo (ma essa lavoura exige muito trabalho e a mercadoria está com preço ruim), e "tudo o resto (lavouras) o limite é a irrigaçăo, que é cara, já de início (em relaçăo ao investimento necessário)".

Pensou em construir tanque (porque na partilha da terra ele ficou sem), mas desistiu porque ia ter que plantar 50 ou $30 \mathrm{~m}$ de árvores.

"Năo. Talvez ră, tanque de peixe (mas lembrou do problema das pessoas querendo pescar)." (Cláudio)

Com a cana ele năo tem tanto prazer como teria se fosse uma outra lavoura; ele năo gosta muito. "(Os produtores rurais) plantando lavoura junto prejudicam-se (devido à maior competiçáo e tamanho reduzido do mercado em que têm acesso); mas se é cana, só ajuda (pelo maior volume de produçáa e preço maior, mais facilmente negociado).

Para Mateus e Gustavo: "Năo dá pra pensar. Com o frango, escala (de produçăo) é a dificuldade; (é atividade que na regiăo) iniciou e já nảo é bom de começar agora. Piscicultura (já está acontecendo) a mais de 5 anos. Falam (frente às vantagens de mercado) em porco." Mas diz que pra construir uma granja, seja de porcos ou de frango, precisa de alto investimento em capital, entre 70 e 100 mil reais.

Estevăo diz năo ter opçăo nenhuma. Mas gostaria: "granja, boi em confinamento, ampliar a propriedade. Sempre trabalhei com gado; depois ficou ruim.

"Falta dinheiro. Tirei peixe (do tanque pra vender) e năo posso por mais, por falta de dinheiro."

Leonardo responde que năo. Planta tomate em outra terra, no Maschietto, fora, em Tieté. Já plantaram tomate aqui, mas deu problemas de tiririca e pragas.

Luís gostaria de plantar tomate. Năo faz por falta de capital e por considerar muito arriscado pegar o dinheiro dos bancos.

Lucas năo pensa em mudar de produçăo. Sobre o pessoal da equipe dos plantios, ele reclama: "Falaram que ia dar peixe e năo deram. Promessa de ser de graça, mas năo veio". Ofereceram tilápia mas ele năo quis. Queria tambaqui, pacu, carpa. Me disse 
que o custo está por volta de R\$ 0,30/peixe pequeno (diferente de alevino, que se compra por milheiro - grupos de 1000). Ele já colocou tucunaré nos tanques mas morreu. Diz que tem "problemas de sistema de água pra tanque de peixe".

O Sobrinho de Thaís vem desenvolvendo um secador de frutas, sem dificuldades. Pra fazer um tanque acha complicado, tem medo. Tinha vontade de desenvolver a piscicultura na propriedade, mas precisaria de uma pessoa jovem. Gostaria de poder fazer isso.

Raquel gostaria de produzir organicamente. Limitaçoes: falta de mercado, tecnologia e por ainda năo acreditar na viabilidade técnica desse modo de produçăo aqui nas nossas condiç̧̋es. "Năo temos inverno aqui; nos EUA é mais sério e ambiente ajuda"(a respeito da neve que acaba com quase tudo, promovendo um tipo de 'limpeza' no sistema).

\section{4b) Balanço geral sobre a motivação frente à localização da propriedade}

José e Ana se dizem acostumados, entâo estaria boa a vida ali. "O que segurou 0 pessoal... (foi que) em 85 chegou eletricidade. 0 gás chegou na década de 60".

"Hoje a terra sem água tem maior valor, o contrário de antes".

"É bom, venho sempre, até de domingo. Na cidade năo tem graça. Aqui o dia passa mais depressa". Joaquim, assim como Carlos, diz năo estar acostumado à bar, na cidade; prefere a roça.

Mateus acha bom, nasceu aqui. "Propriedade é boa, năo vendo. A terra é boa."

Estevăo gosta do lugar. Diz que a terra năo é muito boa, mas foi onde ele criou seus filhos. "Năo faz diferença".

"O que fudeu é por sé pequeno e ter que perdé essa área. Se năo tivesse tanta exigéncia até daria. Năo plantei no tempo certo e agora processo (junto ao promotor), chamando (a comparecer, no dia 04/02/98)".

Leonardo diz que nunca pensou em vender.

Luis gosta do lugar, "apesar de tudo".

Lucas tem avaliaçăo positiva, mesmo com o programa. "(Ele) năo interferiu na produçăo".

\section{4c) Sonho futuro para a propriedade e papel das árvores, animais e água nesse sonho}

José sonha com tanques ao longo de suas nascentes, mas "teria que tirar (as árvores) pra construir o tanque". Acha que as frutas (que calssem das ánores em volta do tanque) năo alimentariam os peixes, e até os prejudicaria. 
Joaquim e Carlos dizem que năo há o que mudar, querem que tudo continue do mesmo jeito.

Mateus diz que năo sonha: "muita insegurança; futuro incerto". Cita as reunióes que já estão acontecendo pra que năo se queime mais a cana: "năo queria mudar (da cana); queria que melhorasse." Reclamam da falta de incentivos, da falta de "máquinas à álcool". Acha que seria bom pra todos converter motores a gasolina/diesel em álcool. Mas se sentem de fora das discussōes, "a Cooperativa năo tem voz. Collor de Melo é que era usineiro, e melhorou muito."

Estevão espera melhorar. Nem pensa muito nisso; "só tocar o que tem". Mas espera pra um ano que seus tanques estejam funcionando, e que tenha "boi no cocho. $\mathrm{Na}$ base que tá e continuando." Năo pensa em sair. "Se pudesse vender e comprar melhor até pensava, mas năo dá. Família toda aqui já a 30 anos", e o filho (já casado e com filho) pensando em ficar com ele, pra tocar junto.

Luís diz que tá precisando de um poço artesiano de $\pm 150 \mathrm{~m}$, que fica \pm em $\mathbf{R} \$ 10.000$.

Lucas quer melhorar a produçăo. Já pensou em granja, mas (têm) muitos fazendo, resolveram desistir. O melhoramento que precisa fazer é barracăo pras máquinas.

Năo vé como ánores e animais possam contribuir.

Raquel quer desenvolver um projeto paisagistico em volta da represa, de eco-turismo, com objetivos educacionais voltados à água.

\section{4d) Relacionamento com vizinhos}

"É muito bom. Sempre se ajudando, participam das decisōes." (José)

"Cada um por si"; Carlos diz que năo se reúnem por outro motivo (como esse dos plantios, na Associaçăo). Sobre a assinatura do termo de compromisso: "Assinei sozinho (quando do momento da assinatura, sem a presença de outros proprietários); já sabia que precisava concordar. Eu procuro minha parte e cada um que se vire."

Roberto, tio de Cláudio, diz que a maioria dos proprietários foram colegas de escola, já se conhecem desde criança, a 60 anos.

"Tem um meio desligado (o vizinho, que năo toma atitude quanto aos seus porcos soltos). Outros săo unidos, trabalham juntos. É legal." (Mateus e Gustavo)

"(O pessoal) Trabalha junto. Sempre ajuda. Quando a usina começou a fazer o serviço (queima, corte, transporte), ficou menor (a cooperaçăo entre vizinhos). Mas sempre se ajudam. A uniăo (entre eles) năo mudou de lá pra cá. Se dăo bem". Estevăo disse que năo costumam se reunir.

Segundo Lucas, o relacionamento é bom.

Thaís acrescenta: "É bom, mas năo se ajudam muito". 


\section{Sobre outros aspectos (piscicultura, críticas e observações)}

\section{5a) Piscicultura na microbacia}

"Tanque em cima é mais difficil de parar água, daí gasta mais água, mais motor (a respeito da proibiçăo de se fazer o tanque em seu próprio vale). Năo causaria problema algum, sem poluiçăo nenhuma (caso fosse feito no vale)".

"Năo tem ajuda pra alevino; ninguém falou nada sobre ajuda". Na época tava R\$100 o milheiro, hoje tá R\$120. "O cascudo faz buraco no tanque". (José e Ana)

Năo interessa a ambos, Joaquim e Carlos. Pra consumo já năo gosta, e "pra venda năo interessa: "já trabalhei muito, năo preciso de mais serviço", diz Joaquim.

Cláudio acha bonito. Como tem pouca terra, pensa que pode ajudar na renda da familia.

Estevăo foi um dos primeiros a ter peixe. "Hoje todo mundo tem e cai preço. Tem que comprar alevino. Tem financiamento, mas năo peguei aqui. PRONAF (verba do programa de valorizaçăo da produçăo familiar) năo chegou. Năo deram. Tem financiamento mais barato pra alevino. Assisténcia técnica até tem, na Cooperativa dos cortadores de cana. Fazem reuniరes na Casa da Agricultura, mandam convite, tem técnicos." Ele diz que năo tem participado muito por falta de tempo; muitas reunióes săo visitas à propriedades ou locais fora da regiăo. Seu tanque ele fez "da cabeça".

Leonardo năo pensa nisso.

Luís năo gosta, "não adianta. Tanque tem que ser perto da casa; se for longe roubam tudo com rede, como já aconteceu com ele.

Segundo Lucas, em sua propriedade năo é uma opçăo muito boa pela dificuldade que têm de água (apesar da represa que possuem).

"Tem que dar um jeito nos pescadores. Pesque-pague năo compensa. É complexo (trabalhar com aglomeraçð̌es). Já cortaram pau, fazem fogueira, destruíram placa". Raquel diz que já existem vários pesque-pagues na regiăo. Alguns já vendem. Seus empregados pescam muito, comem peixe. $O$ uso de rede só é permitido com a autorizaçăo dela.

\section{5b) Causas das análises em 90 e 92 (anexo) e opiniões gerais}

Sobre a acusaçăo de uso indiscriminado do fogo na regiăo, Carlos diz que: "Năo é verdade"; Ele e Joaquim dizem que sempre tiveram cuidado. Discordam também da afirmaçăo de que săo feitas demubadas de matas: "só no passado; mas da década de 50 pra cá, já năo tinha." 
Mateus e Gustavo também năo concordam com a validade das análises apresentadas, para o contexto de sua propriedade: "na propriedade, tudo com orientaçăo, tudo é aferido." Eles dizem ter cuidado com os produtos. Mas concordam que muitos realmente năo fazem isso. Lembram, porém, que : "em lavoura, năo existe perfeiçăo; 0 tempo (climático) é muito difícil (no sentido de năo poder prever algumas coisas, como chuvas intensas). Todos têm um pouco de árvore no sítio". Na propriedade o solo é bom, năo tem erosăo; segundo eles, ela ocorre mais em solo de areia.

O que se fala de organizaçăo e participaçăo deles, está ligado à Cooperativa.

Sobre o uso indiscriminado do fogo, se justificam lembrando do próprio manejo, onde o fogo é importante. "Em 47 năo podia queimar cana, até década de 60 (năo tem certeza), quando era o tempo dos franceses (da usina Uniăo Săo Paulo)."

Năo concordam com o que se coloca de derrubadas de mata: "Aqui năo! Só quando tinha fogåo à lenha!"

Sobre o uso indiscriminado de fogo, diz Estevăo: "É raro escapar um fogo. Uma vez escapou fogo da usina e pegou na capoeira".

Sobre demubada de matas: "Năo ocorrem".

Sobre a colaboraçăo da cana na degradaçăo ambiental, ele năo concorda.

Sobre a imagem de culpados pela degradaçăo ambiental, frente à comunidade, diz que: "Ninguém aqui é culpado. Ninguém tem culpa. É do interesse do proprietário cuidar. $O$ que pode fazer pra năo estragar, faz."

\section{5c) Sobre educação de adultos}

Joaquim concorda com a afirmaçăo apresentada de que o produtor rural, 0 adulto em geral, é cabeça dura quando se fala em mudar alguma coisa pra melhorar a qualidade ambiental. "Tem uns que năo concordam".

Ele fez a comparaçăo com o cinto de segurança: "năo custa nada. A lei dura amansa qualquer um. Acaba com a raiva de quem năo (a) cumpre, (em cima) de quem propós."

Sobre trabalhar de modo educativo com adultos: Estevăo acha que funciona tanto pra crianças como pra adultos: "Se criança entende, porque é que adulto năo vai entender?"

Raquel acha que o modo de pensar do adulto (e do produtor rural) muda, mas tem que mexer em algumas coisas. Segundo ela, a ciéncia diz que até 5 anos de idade, a criança já desenvolveu todo seu potencial. E que as crianças de hoje seriam muito mais espertas, com cabeça muito mais aberta. Os adultos vieram de sistema educacional diferente e foram muito podados. Conta que ela mesma, desde pequena era muito atrevida, năo aceitava as coisas facilmente (sua măe concorda). É a idéia da autoridade e da possibilidade de contestar a autoridade. Hoje, a criança questiona mais. "O brasileiro (e o proprietário rural) năo foi educado para ler. Por exemplo, temos letras impressas (print) que lemos mais comumente, mas aprendemos a letra de măo (script).A pessoa que năo entra em contato com a-informaçăo, se fecha. Daí a vantagem das crianças de hoje, com muita informaçăo. Acredita ser possivel a mudança de comportamento do adulto: a melhor maneira de mudar rapidinho é mexer no bolso (que ameaça o status dele). Assim, diz que na época de vacas magras é mais fácil. Conta que já teve muita decepçăo de ver o quanto o pessoal năo pergunta e năo questiona, e o destino da vida dele tá sendo discutido ali. Acredita que o adulto só 
muda se quer, e ninguém quer mudar. A resistência à mudança do homem do campo é muito grande, diz ela.

Nos projetos que ela têm em mente, quer trabalhar com crianças. Ela năo investiria em adultos. Acha que ninguém muda ninguém. Apenas dá elementos.

\section{5d) 'Causos'}

Carlos lembrou dessa história, quando falava da indignaçăo de alguns proprietários frente à 'perda' de terras, com os plantios.

A pouco tempo atrás houve uma discussáo a respeito dos postes que passam pelo bairro. A companhia de energia elétrica exigia que os proprietários mantivessem distância dos postes de madeira, com suas lavouras de cana, pois já ocorreram casos em que eles foram queimados (junto com a cana, acidentalmente) e a fiaçăo caiu no chăo, com risco de vida pra comunidade. Alguns proprietários levantaram entăo a questăo de que no passado, havia sido sugerido o uso de postes de concreto, e a empresa havia recusado. Agora o ónus recairia sobre os proprietários (aceiros maiores, perda de faixa de lavoura), por culpa de uma decisăo mais conveniente à empresa, naquela época.

Cláudio e o tio Roberto contam uma história (real, segundo eles) de um último lobo guará que apareceu no bairro Boa Vista, a muitos anos atrás, que perseguido por caçadores foi se esconder dentro de uma casa, onde só estava um bebé em seu berço. Ele pulou a janela e ficou escondido em baixo do berço. A casa foi toda fechada e o bebe puxado pra fora. Para caçar o lobo tiveram que abrir um buraco no teto e laçá-lo por cima, até que o imobilizassem. Ele năo foi morto, e por ser um bicho desconhecido do povo da regiåo, todos queriam ir vé-lo no cercado que foi feito pra tal fim; foi dal que o entrevistado o viu. Ao final, acabou sendo vendido pra um circo que estava de passagem por Capivari.

Teve uma época no passado - conta Mateus - em que as máquinas que faziam o transporte de cana, ou eram de caldeira (a lenha, soltando fagulhas perigosas à cana, e năo raro causando incêndios) ou à óleo. Lembra caso em que um amigo năo controlou o próprio fogo e quis enganar usina alegando que tinha sida a máquina. Pro azar dele, justo naquele dia do incêndio, a máquina que fazia a regiăo era a movida à óleo...

\section{5e) Sobre a lavoura de cana}

Cláudio diz que começou em 64,65 . Tinham 8 usinas na regiăo que foram fechando de lá pra cá. Comentou sobre o problema do desemprego que virá com o corte mecånico da cana e questionou as justificativas ambientais dessa açăo: "cana polui muito menos que fábrica. O fogo favorece $100 \%$ a lavoura", explicando que eles năo poderiam deixar de queimá-la.

Antigamente era por cotas e "a gente passava apertado": tinham cota de 500 ton, mas produziram 800; no outro ano ampliaram a cota pra 600 ton, mas produziram 1300. Tinham que se virar pra vender o que excedia a cota; às vezes até tinham que vender pra amigos que năo completavam as próprias cotas, embora isso fosse proibido. Nessa 
época era mais açúcar que era produzido. Depois com o PROALCOOL, as usinas passaram a disputar a cana entre si.

"Se acabar a lavoura de cana o estado năo aguenta; (outra) lavoura năo aguenta..."

Sobre o corte da cana 'verde' (crua), Mateus acredita que vão precisar aumentar a mão-de-obra nas áreas não-mecanizáveis, e reduzi-la nas áreas mecanizáveis.

Discute, ele mais o filho Gustavo, sobre a necessidade de uma politica nacional para o setor sucroalcooleiro: "Quando veio o PROALCOOL, era só (produçăo de) açúcar. Nesse tempo (do PROALCOOL) o preço (da cana) era melhor." Criticam as montadoras, que só estâo fazendo carros à gasolina; percebem a influéncia das questőes macroeconómicas (como a variaçăo dos preços do petróleo e a pressåo criada pela sua futura escassez) e da política intema sobre os destinos da cana ali na região: "Agricultura é sempre quem segura os planos (económicos do govemo)."

Sobre a cana crua, Luís acredita que a palha vai estercar a terra; ele năo é contra. Mas, segundo ele, que paguem o que vai custar mais caro. Ex: "cobre mais o açúcar e consumidor que berre. Vai tirar do nosso bolso de novo !?. (...) Se for cortar sem queimar, usina vai cobrar mais ou năo vai fazer".

Raquel expós sua visăo enquanto presidente da Associaçăo. Levantou alguns problemas de adaptaçăo dos interesses e planejamento da usina, à realidade das propriedades: variedade (BRIX x longevidade da soqueira), cuidados com a soqueira. Cerquilho, por exemplo, já usa variedades diferentes que Capivari. Para o proprietário é interessante que a cana renda um maior número de cortes, mas a usina paga por BRIX e valoriza a produtividade, qualidades que se concentram nos primeiros anos/cortes. $O$ pessoal tem que estar mais atento e cobrar qualidade no corte de sua cana (feito pela usina), devido à soqueira. Cobra deles, nesse sentido, maior participação e se irrita com a situaçăo. Porque existe sempre o risco de perda de ágio por maus tratos na soqueira. O modo de avaliação do volume produzido também dá margem pra confusão. A estimativa dos proprietários é pouco precisa. Existem então alguns problemas entre o planejamento da propriedade e o da usina.

Existe uma acomodaçăo, porque a cana tem preço fixo, por lei, até hoje. Mas isso muda em maio agora (98), quando ele vai ser liberado; será o preço de mercado. A associaçăo trabalha com 2 milhőes de ton de cana e esse novo contexto vai exigir um trabalho maior em cima da produtividade, e de pensar as áreas năo-mecanizáveis. "O risco é de quebradeira feia". Ela entende que o proprietário precisa:

1. usar mais a orientaçăo dos técnicos da associaçăo (orientaçăo sem custo adicional e prontamente disponivel, basta procurar);

2. não negociar sozinho, por conta própria;

3. reduzir seus custos a aumentar produtividade.

Geralmente a orientação não vai até os proprietários. Exceção foi feita, por exemplo, para uma lavoura de tomate, onde o técnico foi enviado para traçar as quadras (dado o alto risco de perda de solo e contaminação de mananciais) e para alguns cultivos que apresentem produtividade baixa. Quanto à análise de terra, a associaçăo possui uma norma: não vai até a propriedade pra tirar amostras. Ensina o proprietário, e este é que deve encaminhá-las à associação. Eles não teriam pessoal suficiente para tal, e pensa que seja realmente obrigaçăo daqueles. Mas os técnicos sempre estão disponiveis pra tirar dúvidas, etc. 
Nas reunið̋es com os proprietários, na Associaçăo, "eles năo entendem e trocam tudo". É difícil atrai-los para encontros desse tipo; "eles tém que aprender que o negócio é deles". A estratégia do churrasco já deu certo uma vez (pra atrair a moçada), mas ela é contra, esperando que os proprietários queiram ir às reunióes por se tratar de assunto de seu interesse. "Năo entendem e năo perguntam, esse é o grande problema". "Pessoal é dificil de entender; a gente fala, fala na associaçăo...é 'catequese' constante, mas enquanto năo mexe nos bolsos dos caras eles năo mudam - produtor de cana virou vagabundo. Năo dá conta da responsabilidade com o vizinho, com 0 ambiente".

Sobre a mecanizaçăo do corte da cana: Raquel diz que viria de todo jeito para a usina, seja por questőes ambientais ou económicas, mas viria em velocidade menor, e daria tempo pra resolver o problema da măo-de-obra. Explica que na Argentina já acabou a queima da cana, mas foi um processo mais bem planejado. Por exemplo, "por que năo se desenvolvem máquinas pequenas adaptadas ao relevo mais acidentado?", pergunta.

Pedro fala sobre as queimadas. Acha que năo causa mal à saúde ou polui. Contribui apenas com pequena porçăo para a poluiçăo do ar. "Năo queimar a cana é mais transtomo (social), maior desemprego". Elas exigem um cuidado maior, como a presença de caminhőes bombeiros e aceiros, que văo de 5 a $10 \mathrm{~m}$.

A respeito da responsabilidades da usina quanto aos plantios em áreas de fornecedores e arrendadas, diz que nas primeiras, a responsabilidade é toda do proprietário, embora a usina tenha muito cuidado nas queimadas. Nas segundas, a usina tem responsabilidade na conservaçăo dos plantios. Em nenhuma delas se responsabiliza em plantar.

\section{5f) Sobre a melhoria das condições ambientais}

"Se vai cuidar (da água aqui no Forquilha) por que jogam esgoto (no Capivari)? Por que pago imposto entăo?" Citou um lava-carros na beira do rio, na cidade.

"Cana respira, é uma mata; é o 'verde' também. O govemo devia aproveitar isso em beneficio do ambiente."

"Cana é como matéria-prima, faz o álcool"; diminui o consumo de petróleo, diminui a poluiçăo do ar e "se reformar a frota de carros (passando pro álcool) aumenta a riqueza e aumenta o emprego!" (Cláudio)

\section{5g) Cobrança pelo uso da água}

Cláudio ouviu dizer que entre os anos 2000 e 2002, o pessoal vai instalar relógios pra cobrar a água deles.

Para Luís, é o mesmo problema que a cana crua: "năo ajudam em nada e văo cobrar".

\section{5h) Sobre o programa de saúde}

Luís conta que existia na usina um plano chamado CEPASA, voltado para acidentes de trabalho, quando os pacientes eram mandados pra Piracicaba, Campinas e tal plano cobria as despesas. O hospital também foi feito, descontando-se dos fomecedores. 
Ércio Bresciani e Cristina acabaram com o hospital. Hoje săo 3 médicos que se revezam em turnos (atendimento gratuito) e se é caso grave tem que dar depósito de R\$ 2000 de garantia, pra depois eles devolverem o que năo foi usado. Existe hoje 0 convénio com a UNIMED, mas para os casos de internaçăo, paga-se 'por fora' (o convênio năo cobre). Entảo ele decidiu pagar mensalmente. Conta que numa ocasiåo, quando precisou ir à Piracicaba, a UNIMED cobrou dele $\mathbf{R} \$ 170,00$ pra uma viagem até Piracicaba $( \pm 30 \mathrm{~km}$ ), alegando que ele deveria ir deitado, acompanhado de enfermeira, e chegando lá, só podia se locomover em cadeira de rodas. Alegaram que era responsabilidade do grupo levá-lo até Piracicaba em segurança, mas ele se irritou porque dizia estar em otimas condiçőes pra ir de carona com amigo, a um custo muito menor.

\section{5i) Avaliaçōes sobre os proprietários locais}

"Preguiçosos, colhem e ficam sossegados. A associaçăo tem lutado pra diversificar, tem interesse em melhorar. Existe entre eles um grupo com interesse e um grupo sem interesse." (Raquel) 


\section{Anexo B}

\section{Entrevistas com os técnicos}

\section{Consórcio}

\section{Ea) Técnicos de campo do Consórcio (Antonio e Flávio)}

\section{Antonio}

Antonio é engenheiro agrónomo que trabalhava com cana; gosta de trabalhar com o ambiente (os plantios das árvores), é da regiăo (tem inclusive parente na microbacia). Passa um sentimento de satisfaçăo de quem está contribuindo para a melhoria do meio, fazendo o que é certo e necessário. Năo questionou a metodologia do Consórcio, embora ele mesmo ficasse mais exposto ao conflito, como técnico de campo da microbacia e habitante em Capivari. Entende a imprescindibilidade da legislaçāo e do promotor para a efetivaçăo dos plantios, sem os quais, o programa năo aconteceria. Năo se mostra interessado nas dificuldades e indignaçơes dos proprietários, mas também năo os julga negativamente, a respeito da 'resisténcia' ao programa. Entende que os proprietários deveriam ter aproveitado a ocasião do apoio oferecido pelo programa para fazer os plantios, a um custo mais baixo. Comparado com a situaçăo em que eles teriam que fazé-los inteiramente por conta própria, ele vê tranquilamente que 0 erro foi dos proprietários (que resistiram e alguns, ainda hoje, com processo).

Levanta alguns aspecto relacionados a um certo improviso da experiencia pioneira, que podem ajudar a explicar alguns dos desempenhos insatisfatórios ou mesmo taxas de mortalidade verificadas em certas propriedades. Por exemplo: o despreparo inicial dos funcionários que năo conheciam as "variedades" das ávores e implantaram alguns projetos de forma "bagunçada". Outro aspecto diz respeito a operacionalizaçăo do viveiro de mudas da prefeitura, nem sempre em compasso com a chegada do recurso financeiro para as etapas de implantação, no campo, levando as mudas a "passarem" do tempo, prejudicando o desenvolvimento do sistema radicular. Quando aconteceu isso, a época mais adequada ao plantio também já havia passado, somando-se àquele fator. Essas informaçőes (embora apareçam como eventos pontuais na história do programa) agravam o contexto analisado anteriormente, onde o mau desempenho dos plantios ou a mortalidade é associada exclusivamente ao descuido dos proprietários, que assim ficam à mercé de serem processados e multados (no sentido de plantarem áreas adicionais). ${ }^{1}$ A năo-criaçăo de um espaço ao diálogo, mesmo que ingenuamente,

\footnotetext{
'Durante o seminário "Implantaçăo de florestas e sua interface social: o estado da arte", Jonas (técnico da Fundaçăo Florestal, responsável direto na parceria com o Consórcio em Capivari) descreve: "Em Capivari, num trabalho de três anos foram plantadas 109.906 mudas. Teoricamente faltariam 16.848 mudas a plantar, mas pela alta mortalidade faltam cerca de $50.000 "$. Dessa informaçăo, calculanos uma mortalidade em tomo de $30 \%$, o que está de acordo com os dados apresentados por Sérgio (atual coordenador do programa, do Consórcio) , em visita técnica à microbacia do Forquilha em 30/07/97. Na ocasiåo, Sérgio associava à falta
} 
acabou sendo, desse modo, muito conveniente à equipe do programa, e lamentável do ponto de vista técnico (citando apenas um aspecto mais prático).

No entanto, Antonio fala com muita segurança da flexibilidade nos acordos quanto à metragem e prazos para se iniciar os plantios. Esse aspecto da metragem foi confirmado em algumas entrevistas com os proprietários, e em uma visita à área de plantio de um deles. Em muitos casos, a faixa teve largura inferior aos $\mathbf{3 0}$ metros exigidos pelo código florestal, sendo aprovados pelo DEPRN. No entanto a equipe não se responsabiliza por futuras cobranças dos órgãos competentes, para o complemento daquilo que pede o código florestal (essa situação é referente tanto aos córregos como para os tanques da mirobacia).

O trabalho educativo, para Antonio, seria algo parecido com a abordagem da Semana da Água, também desenvolvida pelo Consórcio, onde săo realizadas visitas e espaços de comunicação com crianças, professores, técnicos e proprietários, visando passar conteúdos de valorização da preservação ambiental, de modo a mudar seus comportamentos. Essa visăo é desprovida de profundidade em questőes de desenvolvimento rural regional, e de sustentabilidade desse desenvolvimento, reflexăo esta que se faz necessária, em nossa avaliaçăo, no contexto atual da microbacia e da região.

\section{Flávio}

Flávio é engenheiro agrônomo, o atual autônomo contratado pelo Consórcio para realizar as vistorias e os primeiros contatos com os proprietários rurais. Acompanhando um dia de seu trabalho em Arthur Nogueira (SP), pude ter uma idéia do seu método de trabalho. Sua tarefa é cobrir uma área pré-determinada de APPs correspondentes às matas ciliares, de modo a cumprir um patamar de mudas a serem plantadas (prédefinidas) pelo atual programa, dentro de um perímetro a ser "fechado" (completado, contínuo). O modo operacional dessa açăo baseava-se na confecçăo de fotos e no angariamento de adesões ao programa através da assinatura de um documento (de valor legal), nos mesmos moldes daquele usado no Forquilha.

Num primeiro contato com o proprietário, ele apresenta o programa e seus objetivos, cita 0 aspecto legal, mas dá mais énfase à oportunidade que se está oferecendo dentro do programa de se obter gratuitamente um projeto de revegetaçăo e mudas de essências florestais nativas. É realizado o levantamento fotográfico para a elaboração dos laudos (em uma das propriedades este foi realizado mesmo sem a presença do proprietário). Alguns resistiram à idéia, outros năo. Um casal, mostrou-se favorável ao programa desde que pudesse escolher as espécies, e usar área como bosque, área de lazer (à beira de açude). Flávio explicou as limitaçőes, mas só era entendido quando

de manutençăo dos proprietários a maior causa dessa elevada mortalidade. Porém Jonas (tanto no seminário citado quanto na ocasiảo da visita técnica) acrescenta outros fatores: o atraso da prefeitura de Capivari no fomecimento de insumos como terra e esterco, a morosidade do Consórcio, a pouca participaçąo dos proprietários, e o atraso da própria Fundaçảo Florestal na liberaçåo de sementes ao viveiro municipal de Capivari. Em termos gerais, Jonas avalia o processo como "grande desencontro": mudas prontas no período da seca, desperdício de recursos e falta de planejamento. 
falava no rigor da legislaçăo. Existiram algumas barganhas quanto à área de plantio, de modo que pelo menos uma parte da mata ciliar fosse revegetada, sob o argumento de que assim "a florestal năo pegaria no pé". Na propriedade de um político da cidade, a recusa da metragem mínima de $15 \mathrm{~m}$ em favor de apenas $5 \mathrm{~m}$ (na barganha) criou um impasse, que năo se resolveu naquele dia. Outro proprietário exigiu uma cópia do código florestal (pois năo conhecia a lei 4.771 de 1965, citada no documento que ele deveria assinar, aderindo ao programa).

Concluo que o método (reflexo da estrutura da açăo) năo se alterou significativamente de 92 até hoje.

\section{Eb) Coordenadores da Seção de Proteção aos Mananciais, da Secretaria Executiva do Consórcio: Ronaldo e Ester (de 91 a 95/96) e Vito (de 1996 até o momento)}

\section{Ronaldo e Ester}

Ronaldo e Ester foram os primeiros técnicos de campo, que coordenaram os trabalhos da frente de proteçăo aos mananciais, a partir de 1991. Quando procurados para a entrevista, pediram que fosse respeitado o fato de năo mais estarem ligados à instituiçăo, e por isso năo gostariam de dar declaraçర̋es a respeito da instituiçăo, no período em que eram coordenadores (91 a 95).

Fizemos entăo uma conversa, com Ronaldo, mais voltada à compreensăo de suas motivaçoes e princípios profissionais, de modo a entender como se formaram os conflitos verificados no campo.

Ronaldo é geógrafo, que já tinha vivido uma experiencia (positiva, segundo ele) de organização comunitária, a partir do tema "saúde", que teria sido uma demanda da própria comunidade. Ele entende que o sucesso daquela açăo esteve muito associado à atençăo que se deu, inicialmente, às prioridades locais. Ele entende que uma forma altemativa de se trabalhar esse programa poderia ter sido o fortalecimento comunitário, ali no bairro, reforçando as possiveis identidades / necessidades comuns, para a partir disso puxar todo um programa mais amplo.

Ronaldo mostrou valorizar o trabalho com lideranças locais, que realmente representem as dificuldades e anseios da comunidade. Desse modo, ele entende que a questão ambiental seria contemplada também, mas na seqüencia de prioridades da comunidade, e por isso, mais adequada dentro da metodologia da ação. Explica que, na posiçăo em que eles ocupavam na época, eram empregados, sob diretrizes e decisōes da instituição, tinham tarefas a cumprir e prazos. Por isso indica o "caminho da espada" (poder da lei) como o mais fácil, embora conheça e tenha tido experiencias com o processo de organização comunitária.

Levanta a dificuldade (que năo seria só da região, mas de todo o Estado) quanto à escassez de recursos humanos e financeiros, e de uma estrutura de trabalho adequada, para que pudessem desenvolver uma abordagem individualizada junto aos proprietários rurais, de modo a interpretar a legislaçăo de modo mais coerente para cada situaçăo encontrada no campo. 
Acredita que a questão da degradaçăo ambiental na bacia é essencialmente política. Por isso, lembrou-nos que um mérito que é preciso reconhecer (nesse programa) é a possibilidade que o Consórcio criou de sentarem numa mesma mesa estas instituiçסes de poder legal (DEPRN e promotoria) e atuarem em determinadas regiōes.

A visăo que ele tem dos proprietários: não têm dinheiro, estão apertados. Pra consertar um trator, arrumar uma måo de obra pra cuidar de sua lavoura...o que dirá de contratar um ajudante pra fazer plantio e manutençăo em uma floresta. Além disso, ele entende que a questzo da perda de área, que é significativa para todas as propriedades e fundamental para algumas, significa deixar de ganhar uma renda (mesmo que estiver arrendado). Diz que os produtores falam: já arrendei tudo pra usina, ela que cuide desse negócio de reflorestar. A usina fala: a propriedade é dele.

Segundo Ronaldo, existem necessidades básicas pra eles, assim como pra nós: alimentaçăo, saúde, moradia, etc. Por isso, falando em plantios de matas, todos seriam resistentes. Diz que muito poucos, quase nenhum era năo-resistente; um ou outro que quis foi por interesse, pra promoçăo própria ou alguma forma de ganhar algo com isso, que seria a Iógica, explicou Ronaldo.

Para Ronaldo, "uma coisa é vocé ir falar com o proprietário, ficar 3 meses lá, pescando com ele, falando: olha lá aquela plantinha, vê como é importante essa questão..." esperando ele aceitar ou se sensibilizar. Outra coisa é você chegar com a 'espada': "vocé vai fazer, porque é a legislaçăo, se já comprou assim sem mata, comprou com um ónus, e vai ter que recompor". Pergunta: o que nós escolheriamos então, no contexto de prazos, financiamentos e restriçăo de recursos?

Com essas palavras, Ronaldo nos passa uma visăo coerente com os fatos descritos pelos proprietórios, porém contraditória com suas crenças inicialmente colocadas sobre o sucesso e o porqué de um trabalho de organização comunitária. Talvez porque tenha vivido justamente essa contradiçăo, enquanto coordenou o programa.

Sobre a problemática na microbacia, colocou: um programa de proteçăo dos mananciais resolveria o problema de uma microbacia? Claro que năo, diz ele. Acredita ser necessário um enfoque mais amplo, englobando entre outras coisas: planejamento de ocupaçăo e uso do solo, conservaçăo de estradas, conservaçăo de florestas, modos de agricultura. Confirmou que a escolha das bacias se deu por proteçăo aos mananciais de interesse público, estratégicos frente à degradaçăo dos grandes cursos d'àgua como o rio Piracicaba. Disse que a proteçăo dos mananciais era apenas uma entre outras prioridades.

\section{Sérgio}

Sérgio já tinha experiéncia em plantio de exóticas, e com produçăo de nativas, produzidas para a proteçăo de margens de reservatórios da CPFL, tendo implantado o vivero de nativas de Souzas, SP.

Ele avalia que a revolta maior dos proprietários ocorreu numa segunda etapa, quando aqueles que estavam sendo processados eram chamados pelo promotor. A primeira etapa ele entende ter sido tranquila, com as adesőes ao programa, já que a microbacia 
foi beneficiada com o compromisso político assumido pela prefeitura de efetuar os plantios.

"É... o pessoal revoltou...eu acho que revoltaram com isso dal (os processos, na Promotoria). Mas... eu acho que... a primeira fase, que seria, vocé reunir, convencer o produtor, ele aceitar e falar: 'năo...pode plantar', ele aderiu, assinou um termo de adesăo, vocé... eles tiveram um grande beneficio. Porque em outros municípios eles tinham que plantar. Em Capivari o prefeito assumiu o compromisso de plantar. E plantou."

Sérgio mostrou algumas contas sobre os custos:

Considerando aproximadamente 1600 mudas /ha (espaçamento $3 \mathrm{~m} \times 2 \mathrm{~m}$ ), o custo da muda em tomo de $R \$ 0,50$ cada (R\$ 800), mais uns $R \$ 700$ de măo-de-obra para o plantio, e mais R\$ 1000 de măo-de-obra para a manutençăo ao longo de 2 anos, fecharia o cálculo aproximado de $\mathrm{R} \$ 2500 / \mathrm{ha}$.

Ele valoriza muito a atuaçăo do promotor (que seria um exemplo a ser seguido em todos os municípios, e também uma necessidade atual), e também a parceria da prefeitura, além de ficar, de certa forma, indignado com o proprietário que năo aproveitou o beneficio oferecido pelo programa, que disponibilizou recursos para efetivar os plantios.

"Isso daI, eu acho que produtor năo deu muito valor... năo saiu nada do bolso dele. E agora que tá doendo... que o promotor tá chamando, vamo se dizer, tá sendo... chamado pra cumprir a legislaçăo, que ele... a área de preservaçăo permanente vocé năo pode fazer nada. Vocé tem que cuidar dela. Vocé é responsável, por aquilo alf. E ele recebeu plantado, recebeu tudo e num cuidou, acho que agora o promotor th exigindo...Tem uma grande vantagem, o promotor lá: ele abre o processo, ele faz o laudo, pede a perícia, ele multa. Só que ele propøe um acordo: ele converte a multa em reflorestamentos, pra pessoa regularizar a situação. Regularizando, acabou. Daí fica tudo em ordem."

De outro modo, os proprietários poderiam ter que assumir custos maiores, e a obrigaçăo deles seria cobrada do mesmo modo. Obrigaçăo que, no modo de pensar de Sérgio, é muito clara: na área de preservaçăo permanente (APP) năo é permitida qualquer atividade, e o proprietário que desobedece a tal legislaçăo, está irregular e deve reverter sua situaçăo, sob pena de ser processado e multado. Lembra porém, que a multa (no modo de agir do promotor de justiça de Capivari) é conversåo em mudas, em plantio.

Foi provavelmente Sérgio quem teria dito aos proprietários (como encontramos nas entrevistas), mais recentemente, que a faixa de mata ciliar (essa modalidade de APP) pertence à Marinha, e năo à eles. Frente à resposta de que "se é da Marinha, ela que plante e cuide", Sérgio responde: "mas năo foi a Marinha quem desmatou".

"Teve produtor que argumentou que ele, na escritura dele diz que tem direito ao acesso à água. 'Tem, lógico. O senhor têm direito de acesso da água, mas năo necessariamente o senhor tem que devastar tudo'. Falei: 'o gado pode chegar na água'. Nós negociamos, sempre. Deixamos um corredor... Outra: 'o acesso da água 
que o senhor tem, o senhor pode chegar lá, colocar um cano de captação e uma bomba, e tirar a água. Năo é negada a água'. Falei: 'E outra. A faixa, às margens dos rios năo é de ninguém. É da marinha, pela constituiçăo.(...) Năo é de ninguém.(...) Mas quem devastou năo foi a Marinha! E pelo código florestal, a responsabilidade recai diretamente sobre o proprietário, arrendatário... seja lá quem for".

Entende que houve um processo histórico de desmatamento, em que toda a sociedade tem culpa (ele usa o termo "nós"). Mas que pelo menos as faixas de mata ciliar poderiam ter sido preservadas. Coloca que, a questăo é: alguém tem que começar a revegetá-las.

"É... eu acredito que... o que a gente sempre sente do produtor é isso: ele vai perder uma área produtiva. Ele acha que ele tá perdendo área. Ele nåo olha pelo lado social. Ele 'comprou a terra assim', 'já tava assim', 'foi do pai dele', 'já era assim'...'por que que ele tem que plantar'. O argumento que eu uso sempre...'alguém tem que começar'. Falei: 'isso năo era assim. Se o senhor procurar, lá pro bisavó, tataravó do senhor... aqui devia ter mato. Ou, bem antes ainda, aqui devia ter mato. Era uma mata só isso aqui. Fomos nós que demubamos tudo pra agricultura. Só que nós exageramos. Entåo, eu acho que a gente pode fazer um minimo de devolver essa faixa'.

Sobre a situação nas bacias dos rios Piracicaba e Capivari, Sérgio se apoia nos levantamentos do Consórcio:

"Bom. Na minha visão, como é que está a situaçăo atual da bacia. Nós tamo ainda a caminho do caos, né. Mais do que sabido isso dal. O Consórcio tinha um estudo feito, que em 2010, ia ter um colapso total por falta d'água. Mas nós estamos achando que isso vai ocorrer bem antes, pelo desenvolvimento que tava, como se diz, mais... mais acelerado que ... no que foi estimado, e os problemas também cresceram, agravaramse, né. Hoje, noventa e... acho que $98 \%$ do esgoto năo é tratado..."

O pouco que é tratado (ele acredita ser industrial, em sua maior parte) ainda assim conteriam residuos poluentes que certas brechas na legislação deixavam passar ${ }^{4}$.

Sérgio diz ainda que as prefeituras, tradicionalmente năo tratariam seus esgotos devido à escassez de recursos, problema esse que, segundo ele, começa a ser resolvido com a perspectiva dos recursos disponibilizados pelo FEHIDRO ${ }^{2}$, voltado ao investimento dessas estruturas. As estaçöes de tratamento já estariam sendo construidas, ampliadas ou reativadas, e os compromissos políticos dos prefeitos sinalizariam um próximo incremento dessas operaç̋̋es, no âmbito dos municípios.

Nesse ponto, gostariamos provocar uma maior reflexăo.

A questão da omissão das prefeituras quanto ao tratamento de esgoto é um ponto que aumenta nossa indignaçăo, partindo de uma leitura mais ampla e crítica da realidade

\footnotetext{
${ }^{1}$ Refere-se, provavelmente à obrigatoriedade de reduçảo de (no mínimo) $80 \%$ da carga poluidora industrial, prevista pela legislaçäo estadual (Såo Paulo, 1994).

${ }^{2}$ Fundo Estadual de Recursos Hídricos.
} 
regional e do contexto no qual se desenvolveu o programa aqui estudado. Os centros urbanos se desenvolvem às custas de recursos naturais como a água; a população rural aos poucos busca nas cidades melhores condiçðes de vida, melhores oportunidades (já que seu modo de vida no campo foi sendo pouco a pouco desestruturado principalmente por políticas de desenvolvimento económico que concentraram a posse da terra, a renda e a esses dirigiram seus serviços institucionais) e constituíram-se măo-de-obra da industrializaçăo. Uma das consequências foi a poluiçăo dos principais recursos hídricos (esgoto doméstico e industrial). Ao longo dos anos resolvem estrategicamente represar alguns ribeiröes, geralmente na zona rural próxima às cidades, para garantir tal abastecimento. Hoje, os municípios se reunem em um Consórcio, de modo a melhor resolver seus problemas comuns (inclusive o do abastecimento de água, já que degradaram e năo tem muita pressa em parar de degradar seus rios), e decidem proteger aqueles pequenos reservatórios da potencial açăo poluidora daqueles que lá moram antes mesmo destes pequenos reservatórios serem construidos. Para tal, usam de forma pontual (fruto de uma visåo reducionista), de uma legislaçăo ambiental que é desrespeitada em todo o Estado e de forma democrática: por produtores familiares, pelas universidades (como a ESALQ), pelas áreas das prefeituras, pelos grandes fazendeiros, pelos loteamentos nas periferias urbanas, etc. Aplicam tal lei, e contribuem na desestruturaçăo do modo de vida rural, sem mostrar qualquer preocupaçăo na avaliaçăo dos variados impactos que podem estar ocorrendo ou que o próprio programa pode ter criado. Isso tudo é feito em nome da conservação do recurso hídrico, que no caso da represa da microbacia do ribeirăo Forquilha, nem o Consórcio, nem o SAAE de Capivari, tem sequer uma análise da qualidade da água que está abastecendo a cidade (fevereiro de 98).

Sérgio fala em uma segunda fase dos trabalhos do Consórcio nas microbacias em que desenvolveram o programa; esta estaria mais atenta à conservaçăo e relocaçăo das estradas, o que Sérgio explica que provavelmente pode trazer novas perdas de área aos proprietários

O trabalho educativo com proprietários rurais, Sérgio assume năo existir. Algumas integraçð̌es entre o programa Semana da Água e a frente de Proteçăo aos Mananciais começam a ser estabelecidas, principalmente pelo entrosamento entre os seus coordenadores. O espaço que Sérgio diz existir, que mais se aproximaria de um trabalho educativo, seriam as reuniōes e divulgaçăo e lançamento do programa nos municipios. Mas, diz que geralmente se caracterizam pelo clima de desconfiança e deboche dos proprietários, que sentem que estăo sendo enganados para que o Consórcio consiga suas terras para plantar as árvores. Sérgio entende um possível processo educativo como a conscientização do proprietário rural, e diz ser muito difícil pra equipe do Consórcio desenvolver isso, devido às limitaçőes de tempo. Faz uma crítica às secretarias de educaçăo (que seriam as parceiras mais indicadas, por serem do próprio município), que năo aceitariam trabalhar nessa perspectiva, dentro do programa.

Uma questăo fundamental que veio à tona na conversa com Sérgio foi a comparaçăo do programa do Consórcio com o Programa Estadual de Manejo e Conservaçăo do 
Solo em Microbacias do Paraná (o 'Paraná Rural')" e com o Programa Microbacias, da $\mathrm{CATI}^{4}$, e com o trabalho da CODASP, na conservaçăo do solo e estradas rurais. 0 programa do Paraná poderia ser caracterizado como um programa integrado de desenvolvimento nural, onde vários aspectos săo abordados nesta açăo (produtividade agrícola, conservação dos solos, reflorestamento ciliar, quebra-ventos, etc), e a avaliaçåo nos faz entender que o programa teve sucesso, com uma lista de 11 tipos de beneficios propiciados aos proprietários (entre eles, aumento da renda), e que a adesăo a um programa desses foi massiva e realmente espontânea. Sérgio, que me apresentou o artigo sobre esse programa, diz querer conhecê-lo melhor, para trazer à nossa realidade. Um pouco mais próximo de nós está o trabalho da CODASP de conservaçåo do solo e vias, que Sérgio entende como uma atividade onde o Consórcio já atua e pretende atuar cada vez mais, sugerindo um parceria. Quanto ao Microbacias, da CATI, a oportunidade de parceria fica mais evidente ainda: é um programa também de abordagem integrada, como o "Paraná Rural", que elege certas microbacias do Estado para esta ação. Sérgio critica a disputa que existe entre esses potenciais parceiros, pelos ganhos politicos, e acha dificil o estabelecimento das parcerias, deixando entender que falta vontade.

Entendemos que 0 aspecto negativo do programa nåo está em selecionar microbacias que hoje são fundamentais para o abastecimento urbano, mas sim o modo disciplinar e reducionista como esse programa está estuturado. Esse enfoque poderia ser transformado através, por exemplo, de uma parceria com a CATI, que pela própria razão de existir estaria resguardando os interesses dos proprietários rurais (renda agrícola, infra-estrutura, informaçőes técnicas, assistência técnica, conservaçăo dos solos e estradas, melhoria da eficiência dos sistemas de produção, orientaçőes mercadológicas, fomento à organizaçăo). Para que isso acontecesse, CATI, prefeitura - Consórcio estariam elegendo microbacias de abastecimento público no meio rural, além das outras microbacias em que a CATI continuaria trabalhando em seu programa. Há que se romper com vaidades e interesses corporativistas para a realizaçăo de um trabalho sinceramente integrado e responsável diante do atual quadro de degradação ambiental.

Sérgio coloca como limitaçăo à esse trabalho mais integrado, a própria experiência, conhecimento da equipe do Consórcio, e a escassez de recursos.

Para ele, avaliaçőes do programa são muito bem-vindas, pois significam a possibilidade de conhecer e atacar os pontos fracos.

"(...) Porque eu acho que vai trazer subsidios pra gente atacar o ponto negativo da coisa. Tentar reverter a situaçăo. À medida que vocé conseguir convencer o produtor que é um bom negócio pra ele isso dal, eu acho que vai ficar sempre... sempre mais fácil. E a melhor propaganda é aquela que é...fala boca à boca. Se vocé... se tiver produtores satisfeitos com o reflorestamento, você vai ter novas adesões espontâneas. E isso daí... a gente pretende chegar nisso dai. Seria o ideal chegar nisso daí. Entăo vocé produzir muda e ir lá plantar... porque năo plantar pra ele, sabendo que ele vai cuidar? Vocé tem certeza. Hoje... a gente acha que ir lá e plantar é você jogar muda fora, em alguns lugares."

\footnotetext{
${ }^{3}$ Apresentamos de forma resumida tal progrma descrito por Resende (1996) no item 1.4.

${ }^{4}$ Bertolini et al. (1993).
} 


\section{Ec) Coordenador geral da Secretaria Executiva do Consórcio}

Almir é geb́logo (USP,71), Mestre em Geotecnia (USP,84) Especialista técnico da CESP, Co-Autor de "A luta pela água nas bacias dos rios Piracicaba e Capivari".

Como coordenador geral, que coordena as aç̋es do programa desde o início, além e ser um de seus idealizadores, seu depoimento é fundamental para a compreensăo do porque das açס̋es terem se desenvolvido como se desenvolveram.

Recuperar e proteger os mananciais de abastecimento seria o objetivo do Consórcio: "(...) é a principal prioridade: recuperar e proteger os mananciais de abastecimento. É isso que é a existéncia do Consórcio.(...) Só que em vez de começar com grandes rios regionais - Atibaia, Corumbatal - a gente resolveu começar com um projeto piloto, pequenos projetos, que era Capivari - que é pequena regiăo -, que é a cidade que eu conheço, que eu conheci os produtores rurais, conheci o promotor (...) eu sou de Capivari. Al foi escolhido Nova Odessa e Sumaré, por ser próximo aqui também, e por serem cidades que dependem de pequenos rios, pra voce começar por al. Em Capivari já havia um clima do promotor se preocupar com essas questoes também."

Como já descrito anteriormente ${ }^{1}$, Almir buscou em uma experiência do Paraná, a configuraçăo do programa do Consórcio:

"...e a ADEAM, ela negocia o seguinte, um princípio que a gente sempre adota aqui: 'da cenoura e do porrete'; isso na Europa, os franceses usam isso. (...) Funciona o seguinte: vocé dá alguma coisa mas também mostra a força da lei atrás. Vocé acena com alguma coisa em beneficio, mas também acena com o porrete."

Segundo Almir, a estratégia desenvolvida visava principalmente um meio de possibilitar a manutençăo dos plantios, pelos proprietários rurais, vinculado a um 'fato legal'.

"A hora que vocé faz o laudo, faz o projeto, e acusa que aquela área de preservaçăo năo tá protegida, vocé cria um fato legal, que o promotor é obrigado a tomar uma providéncia. E al o que nós fizemos: criou aquela puta expectativa dos produtores. Al nós acenamos com a cenoura (...) que era o seguinte: "tem a força da lei, mas nós năo vamos querer que precisa cumprir. Nós queremos dar a muda pra vocés, vamos fazer o projeto, queremos discutir o cronograma...". Assim que começou o projeto. Porque vocé năo tem condiçőes de fazer um projeto que o produtor năo assuma aquilo lá. Ele deixa queimar mesmo assumindo com a lei, promotor, ele deixa queimar, ele perde muda..."

Segundo ele, foi projeto pioneiro no ESP, "porque até entăo, no Paraná, a ADEAM tava fazendo isso; nós trouxemos pra cá".

Então se expandiu, graças ao panorama favorável conseguido com o auxillio financeiro batalhado:

\footnotetext{
${ }^{1}$ No item 1.5, "O Programa de Reflorestamento Ciliar do Consórcio".
} 
"Mas veja bem, depois disso, nós fizemos esse pedido de financiamento ao Ministério do Meio Ambiente... que isso fosse um reforço a esse programa. Chamamos as cidades que queriam participar, e onze municipios aderiram, entre os quais os 3 (Capivari, Sumaré e Nova Odessa) que já estavam com a gente. (...) Chamamos técnicos, prefeitos... daí nós pleiteamos o recurso ao Ministério do Meio Ambiente, e esse recurso veio, e ele na realidade agora, ele deu uma alavancagem: ele permite contratar măo-de-obra, contratar o projeto... veio recurso pra fazer isso. Agora, fica de novo o problema da sustentaçăo, das mudas, etc."

Durante a entrevista, insistimos na questăo de um diagnóstico inicial sobre os problemas de conservação da água e do solo na microbacia, para conhecermos sua leitura das relaçóes de causa e efeito que estariam concretamente ocorrendo no Forquilha:

"(No começo) não precisava fazer diagnóstico técnico (...) Precisava fazer... nós escolhemos o Forquilha pra fazer a proteçăo dos mananciais, e ao mesmo tempo pra fazer esse diagnóstico al, de uso/ocupaçăo do solo. E tinha indicaçăo dos grandes problemas que pudessem contribuir pra esse reservatório. E começamos a atuar."

Cita entre essas indicaçǒes um lavador de batatas e um abatedouro clandestino. ${ }^{2}$

Outra provocaçăo constante que fazemos a Almir, envolve nossa leitura do caráter pontual das açőes do programa, sugerindo uma visăo reducionista do problema, e que assim, comprometeria a qualidade dos resultados esperados nessa açăo. Almir explica:

"Ou seja, a idéia nossa era começar com o reflorestamento, chamar a atençăo do serviço de água para a poteçăo dos mananciais, pra ver se o próprio serviço de água começa a assumir essa proteçăo... O que acontece hoje: o serviço de água (SAEE Serviço Autônomo de Água e Esgoto) tem uma tradiçăo aqui que pra ele, só interessa da estaçăo de tratamento de água pra dentro. No manancial, ele coloca a bomba lá... é uma casa de bomba. Ele năo tem mentalidade de proteger o manancial. Se preocupa 'da estaçăo de tratamento de água pra dentro. Então nós queriamos chamar a atençăo pra ele analisar agrotóxico, pra analisar erosăo, as estradas. O IPT começou fazendo isso e năo terminou (...)."

Frente às impressões negativas que tivemos dos proprietários entrevistados em janeiro de 1998 (pela năo-participaçăo nos modelos, comunicaçăo de măo-única, impacto

\footnotetext{
${ }^{2}$ Embora não tenha sido citado em nenhuma ocasião, pensamos que o 'Plano de Manejo da Bacia Hidrográfica do Forquilha' desenvolvido pela CATI (Såo Paulo, 1990) tenha influenciado as leituras que tomam todos os proprietários da bacia, indistintamente, como degradadores, e até embasado "tecnicarnente" as açōes desenvolvidas no programa. Ocorre que o plano de manejo em questảo, de 1990, embora apresente um diagnóstico genérico para toda a bacia, tem um enfoque mais amplo sobre a conservaçáo do solo e da água. Até o momento, nảo conseguimos localizar a equipe de campo da CATI, responsável por tal Plano, a fím de conhecer o método e os dados que deram origem as conclusőes nele apresentadas. A avaliaçáo do Instituto de Pesquisas Tecnológicas de Sảo Paulo (IPT) sobre os impactos do uso/ocupação do solo no Forquilha sobre o resenvatório, ainda nảo está disponivel (informou Sérgio).
} 
negativo da faixa ciliar na economia da propriedade, com abandono de algumas atividades), Almir se mostra surpreso:

"Eu acho que vocé tá totalmente equivocado... levaram voce no bico! Levaram vocé no bico. Procure o [Ronaldo]. Vocé vai ter outra imagem, completamente diferente... ele vai ficar surpreso! (....)

Explica que ninguém foi obrigado a parar nehuma atividade, e se irrita com essa afirmaçăo:

'Veja bem, veja qual que é a orientaçăo: jamais nós vamos (fazer) cumprir a lei. Nós năo precisamos cumprir a lei. O Consórcio é uma associaçăo de poluidores. Nós năo somos cumpridores de lei. A orientaçăo que tem é: 'năo pode plantar $\mathbf{3 0}$ metros, planta 5 , planta 2 . O cronograma quem discute, quem forma é o produtor."

Entende que os proprietários aproveitaram a ocasiăo do espaço criado nas entevistas, para nos enganar ou aumentar os fatos, uma vez que teriam nos reconhecido como aliados $^{3}$.

Almir, embora năo tenha participado deste trabalho no campo, com os proprietários, acredita fortemente que o esquema funcionou, e assim, que os acordos foram legitimos:

"Quando o pessoal visita, tinha autorizaçăo, o pessoal avisava que tinha alguma perda significativa, tinha que renegociar: renegociar a largura de faixa, o cronograma que ia fazer isso, entende? Ver se isso afetava... ninguém foi obrigado a fazer as coisas assim năo! Porque năo tinha essa obrigaçăo toda pra fazer as coisas... nunca teve! (...) Que nada! Ele chegava a ter processo, agora se o cara joga um papelzinho lá... (...) Nunca fez nada! Nunca aconteceu (a liquidaçăo, execuçăo do processo)! Nunca! E năo vai acontecer nunca!"

Defende esse procedimento como uma forma de favorecer os plantios, apenas

"Entăo veja bem: só tem um jeito de você procurar o equilíbrio entre a puniçăo e a benfeitoria que voce̊ faz; eu pergunto: alguém foi punido por năo ter preservado, ou feito alguma coisa, deixado queimar? Foram pressionados, foram chamados pelo promotor, foram conversar. Se ele quisesse continuar com o que ele quisesse... nenhuma... năo houve nenhuma interrupçăo de atividade económica por nenhum! Isso é tudo conversa! Se o cara ficou inviável, é por causa da tecnologia que ele tá usando, vocé tá entendendo? É logico que é isso! Ele faliu... ele tá indo à faléncia, o agricultor, por outros motivos, da conjuntura nacional, isso é questăo da tecnologia... imagina que

\footnotetext{
${ }^{3}$ A esse respeito, é muito oportuna a análise que Becker (1994) faz da acusação dos desvios (bias) no método de pesquisa:

"(...) uma característica da estrutura de qualquer organizaçảo estratificada é que os representantes comuns da sociedade rotineiramente atribuem maior credibilidade à história contada por aqueles por aqueles que a administram do que às histórias daqueles que estão nos niveis inferiores na hierarquia. O sociólogo provoca a acusaçảo de tendencioso sempre que diz alguma coisa que nega a legitimidade da hierarquia de credibilidade." (Becker,1994: p. 32)
} 
é isso! Isso é ridículo! Que foi pelo próprio esgotamento do solo, e foi por uma série de programas dele, de projetos em que ele não consegue mais competir (...)."

Como não nos apronfundamos na avaliaçăo (quantitativa e qualitativa) dos impactos económicos causados pelos plantios, nessa estrutura fundiária heterogénea, demos menos importảncia à esse possivel impacto (provável ou improvável, dependendo da posiçăo que ocupa o entrevistado nesse canário), sem deixar de considerar que o conflito existiu, e se perpetua até o presente, ainda que se questione a veracidade do conteúdo dos depoimentos.

Quando questionado sobre a possibilidade de modificação desses procedimentos, no sentido de uma abordagem diferente com os proprietários, Almir argumenta sobre os custos e explica as limitaçóes a que estiveram sujeitos, durante o programa no Forquilha. Nesse momento, ele deixa claro suas convicçoes, que justificariam o método de trabalho adotado:

'Vocé fala 'comunicaçăo'. Sabe quanto custa fazer isso? Vocé já fez as contas, o que é manter um engenheiro no campo, trabalhando nisso? Fazendo panfleto, fazendo divulgaçăo, fazendo reuniăo, tudo isso...? Custa uma fortuna, amigo! Custa isso! E depois outra coisa: nós tamo numa bacia hidrográfica de $14 \mathrm{mil} \mathrm{km}^{2}$. Temos 5 pessoas trabalhando. Tem um encarregado ou dois - que foi Sandra e Evandro - que saiu depois do projeto, o que deu uma descontinuidade grande, que eles tinha uma dinámica que veio com a CESP - a Sandra veio da CESP, como eu - e foi tratado com a ADEAM que a metodologia, que é o que eu tó dizendo, de negociaçăo, onde se vocé não tiver o poder de negociaçăo você tá fracassado. Se năo tiver lei vocế năo faz nada! Nego te leva no bico em tudol Tá entendendo? E essa lei é ténue ainda de ser aplicada, é super ténue. E outra coisa: nós năo tamos protegendo um rio qualquer. Que se Capivari tivesse isso na cabeça, seria um grande atrativo pra cidade: uma das poucas cidades que tem um manancial que pode tratar por métodos convencionais que pode năo ser poluído nunca! Ela durar até $2100,2200 \ldots$ um manancial sem ser poluído! Isto tem um valor tremendo!"

Almir se mostra muito flexivel quanto aos elementos que comporiam o modelo de revegetaçăo a ser utilizado, que poderiam ser mais facilmente aceitos pelos proprietários. Isso seria totalmente contraditório com o que realmente aconteceu, na atuaçăo de Ronaldo e Ester, rígidos em evitar qualquer perspectiva de uso dessas áreas pelos proprietários, mesmo que apenas coleta de frutos. Mas Almir explica:

"Por exemplo: (...) enfiar a muda lá de goiaba, de fruta... enfia, meu! Nós năo tamo nem al. Agora veja bem: isso sou eu. Agora, o engenheiro que tá mexendo com ele, pode fazer isso e assinar? Năo podel Quem tem que fazer é o cara lá, ir fazer. Ele năo pode assinar isso! Que profissional que faz isso? Cassa sua carta, de CREA! Ce tá entendendo? Agora, nós năo. Nós tamo com preocupaçăo é com a água, nós năo tamo... (...)"

Nesse sentido, indica que os problemas estão na negociaçăo com o DEPRN, sem tal flexibilidade, e sob risco de serem responsabilizados por acordos informais com os proprietários que náo encontram na legislaçăo, respaldo. 
Para Almir, a regeneraçăo natural năo seria uma boa estratégia:

'Vai demorar (...). Mas acontece que essa regeneraçăo é problemática... nego bota fogo depois... Al mexe, bota fogo..."

Sobre o trabalho integrado com as Casas da Agricultura (CATI), que consideramos muito interessante, comenta:

"(...) Inclusive eu tive visitando a secretaria várias vezes. A secretaria năo conseguiu priorizar as nossas bacias. Eles elegeram as bacias, tendo como ponto de vista produtividade rural, que năo săo as mesmas que nós elegemos.(...) Eles tăo lá com outras bacias do estado. Nós chegamos a pegar, e ver se as casas da agricultura, por exemplo, pudessem ceder funcionário pra trabalhar com a gente no programa. Năo se consegue fazer esse povo trabalhar. Os agrónomos só trabalham se receberem um adicional, se pagarem, năo tăo a fim de trabalhar (...) Qual que é a dificuldade do pessoal das Casas da Agricultura: săo pessoal de iniciativa? Săo pessoal realmente interessado em alguma coisa? Entăo se vocé năo tiver valores humanos, treinados, capacitados, você năo consegue nada no pals...năo é só nessa dal. Vocé vai conversar com o cara o cara năo tem tesăo. Olha pra vocé: ' $O$ que que esse cara quer? Que eu trabalhe de graça?' Entåo veja bem, nós tentamos... acabamo agora fazendo uma outra carta... Vito tá conversando de novo na Secretaria da Agricultura, pedindo apoio, pra sessão de um agronomo pro Consórcio. Vamo ve o que é que vai acontecer. Como (...) a Casa da Agricultura cede pra prefeitura, a prefeitura (...) empresta pro Consórcio, pra colocar no campo pra ficar trabalhando. Eu já fui conversar pessoalmente... al o pessoal começa a colocar dificuldade. Então năo é isso. Se a gente tivesse achado um agrónomo com tesăo ele ia atrás, năo achamos um! Se ainda tivesse um funcionário trabalhando no lugar, que conhecesse o Consórcio...: 'Vocé năo quer (...) acertar pra que eu venha pra cá?' Vocé năo consegue...pô, o cara năo procura serviço. Ele năo cresce, năo procura serviço, năo cresce profissionalmente. Aḷ năo faz trabalho, năo se projeta profissionalmente. Ali vocế năo abre um campo pro pessoal trabalhar dentro do serviço de água, como um cara que trabalha na área de proteçăo de mananciais"

É forte o destaque de Almir dá à necessidade do envolvimento pessoal (individual) dos técnicos, tanto quanto de suas instituições, que desejam trabalhar em parceria, para que os trabalhos se efetivem.

"Săo as pessoas. Formaçăo individual. Năo encontra as pessoas capazes de ter alguma forma de interesse, formaçăo. Eu năo acredito que seja... năo adianta dizer, é instituiçăo, năo... Săo pessoas. As pessoas que estăo ficando nesses empregos públicos, săo as menos qualificadas. Pessoas desmotivadas, sem tesăo... Em Capivari vocé năo tem técnico pra vocé ter diálogo. Năo tem. Năo ficam na prefeitura, năo săo atraídas pelo salário da prefeitura. Pessoas pra conversar sobre isso. É um desastre. Entăo vocé vai conversar, veja bem, vamos supor que vocé...todo mundo tá vendo que, precisava introduzir espécies que possam ser aproveitadas economicamente. Isso é tăo claro pra mim...mas é claro pras pessoas que tăo trabalhando nessa área e que têm o poder de fiscalização? Um desastre! Um desastrel $E$ por que isso? É educaçáo. Já vem de educaçăo da escola, vem da formaçăo, é uma coisa intrínseca. Năo 
depende da estrutura, da chefia dele. É da pessoa. Nós temos mania de achar que um problema desse é a prefeitura...é nada. É da pessoa."

Dá como exemplo a própria ESALQ, que năo teria demonstrado interesse em se envolver no programa, segundo ele:

"Por exemplo, a gente queria fazer uma análise (...) pra visitar... Chegamos a falar com a ESALQ, pra ver se a ESALQ fazia também... 'năo tem tempo'. Fazer um diagnóstico da parte de plantio, das espécies mais adequadas, será que funcionou essas espécies, será que năo era hora de mudar, de invés da gente ficar coletando semente de um monte de coisa, concentrar pra 20,10,15... essa variaçăo nós precisamos ter. Isso aí pra nós, se tivesse algum trabalho feito nisso..."

Exprime uma preocupaçăo em avaliar o desenvolvimento dos plantios, realizados pelo programa, quando cita os trabalhos desevolvidos pelo Prof. Paulo Kageyama: ${ }^{4}$

"Gosto muito dele... da metodologia, se é pioneira, secundária, as várias espécies...puta, adoro ele. Mas entáo...mas agora nós queríamos que, no caso especifico nosso, os erros, os acertos, que espécies... medir lá - que os nego medem o diâmetro, ver idade...sabe? - ter um refinamento dessas coisas, assim."

Demonsta também muito otimismo na continuidade e nos resultados esperados da açăo que vêm desenvolvendo pelo Consórcio:

"Já que nós távamos pensando em chamar o IPT pra ver o restante da bacia, pra uso/ocupaçăo de solo, e a legislaçăo? Nós queríamos fazer uma legislaçăo... queria fazer tipo assim...as idéias: pensar um condomínio naquela bacia. Já pensou se pudesse ter um símbolo de condomínio, porque... pó...naquela bacia, eles se sentirem responsáveis por aquilo tudo. Por exemplo, tivemo a grata satisfaçăo de ver que a bacia do Forquilha, em imagem do satélite, já aparece o reflorestamento. O Pessoal já conseguiu identificar: olha essa bacia tá diferente da região, percebe? Então, criar esse vinculo, de identidade, de condominio."

Sobre a importância da cana no contexto do programa, parece-nos esquecida a heterogeneidade de caracteristicas (área, escolaridade, idade) e condiçōes (poder de barganha, situaçăo financeira) entre os proprietários:

"Pois é, a cana. Agora, o que que vocé faz na cana? Vocé se afastou, teve uma postura...'olha, vou deixar 5 metros, tá bom. Vou fazer tanto...pó, de fato, valoriza minha propriedade aqui, ter um negócio desses. Quanto que eu vou perder aqui, vou fazer as contas... vou aumentar a produtividade pra lá...Vocés tem alguém que pode dar uma dica de como aumentar a produtividade? Tem alguma coisa? Cooperativa? Tudo é negociável, tudo é pra fazer! $O$ que é que você faz, se chega com as usinas, hoje, que tem técnicos mais capacitados, o cara... vocé tem um puta dum diálogo. A

\footnotetext{
${ }^{4}$ Prof. Dr. Paulo Y. Kageyama, que desenvolve trabalhos na área de revegetaçáo e conservaçảo genética de esséncias nativas, do Departamento de Ciéncias Florestais da ESALQ/USP, Piracicaba (SP).
} 
Cristina plantou quando ela quis, do jeito que ela quis, a hora que ela quis...entende? Exigiu da prefeitura tudo o que ela quis... porque ela negociou!"

Almir percebe 0 andamento das açőes no passado de modo diferente, sempre ressaltando o lado dos técnicos, que faziam muito, frente às dificuldades vividas:

"O que eu vejo, é que o [Ronaldo], a [Ester], eles corriam atrás. E o [Ronaldo] e a [Ester] sempre tiveram um bom relacionamento com esse pessoal. Carlinhos também. Sempre teve bem , esse relacionamento.(...) Veja o seguinte: uma vez o pessoal fez uma reuniăo com os produtores, organizadamente, protestando que tava muito caro pra eles. Mostramos que fica caro pro poder público arcar com o resto que tava arcando. Fica caro pros dois. Agora: tem que fazer ou năo tem? É um negócio supérfluo que nós tamo fazendo?"

Quando perguntei sobre o impacto da mata ciliar na conservaçăo, e o disperdício de água em Capivari, Almir explica:

"(...) É a microbacia, entăo...veja bem. (...) O reflorestamento, a proteçăo... tem alguns estudos, o Vito inclusive tem alguns estudos al, já confirmados de segurar assoreamento. Năo precisa ser só a mata. Quer dizer, sendo uma vegetaçăo, dá resultado. Năo somos contra ter a vegetaçăo. $O$ problema é da legislaçăo ... é outra inståncia. Entăo, basta pra nós ter $5 \mathrm{~m}$, recuou, nós já ficamos contente. (...)Você entăo teria uma medida de recuar a cultura - por que a cultura, ela năo vem só com o problema do assoreamento. Ela vem com agrotóxico, ela vem com os adubos. Por exemplo, eu ando lá em Capivari. Tem regiờes que năo tá poluído, mas năo tem mais vida na água. Por causa de nitrogénio e $m$ excesso. De adubo em excesso, que chega aos córregos. Entăo os fundos de córregos estăo com alga, estăo tăo carregados hoje de nutrientes que náo tem mais vida, năo tem mais peixe. Năo consegue mais proliferar mais peixe. $\mathrm{O}$ que que vocé vai poder fazer com isso: vocé vai ter que tentar um cordăo de proteçăo. Qual vai ser o cordáo? É uma vegetaçăo: grama, mata, aquilo que vocé pode ter. Vai reduzir? Entáo tem alguns estudos que mostra que reduz, agora, só isso vai reduzir? Năo. Precisa ver as estradas, precisa ver erosăo, precisa ver os córregos influentes, tudo isso... a legislaçăo. Eu năo tenho dúvida que vai chegar num ponto que... vai ser chegar num ponto, falado: 'năo vai poder usar tais agrotóxicos aqui nessa regiăo, por causa que é uma bacia de alimentaçăo da cidade. Agora, năo é preciso que o produtor pague isso, pague esse preço. A cidade tem que pagar esse preço. Entende? A cidade tem que pagar. E ai, que o problema nosso é que năo conseguimos sensibilizar o serviço de água."

Sobre a possibilidade de introduçăo de uma abordagem educativa em programas de reflorestamento, Almir explica as limitaçōes (embora tenha entendido o trabalho educativo como atividade pontual de sensibilizaçăo dos proprietários, e năo como estrutura participativa de açăo para e com os proprietários, dentro de uma abordagem integrada e interdisciplinar):

"Isso é uma outra coisa, veja bem. Tudo o que vocé vai fazer, tem alguém que tem que pagar. Uma das dificuldades nossas é nunca fazer as contas assim: isso eu quero fazer, isso custa... cadé a fonte de financiamento? Năo propỏe coisa que năo tem 
financiamento. Năo propõe coisa que vocé năo vai conseguir ser viável. Quem que vai pagar?"

Mais uma vez critica o năo envolvimento do SAAE:

"Quem pode pagar isso é o serviço de água. Que jeito? Ele pode pagar com a tarifa ou ele repassar essa tarifa pra populaçăo da cidade pagar. (...)

Por exemplo: cobrar pra ter uma pessoa fazendo educaçăo ambiental lá. Vocé acha que o serviço de água năo pode contratar uma pessoa pra deixar no manancial, fazendo o que vocé achar que vocé vai propor? Agora, eu vou, eu sou do serviço de água, eu Marco, pra mim eu vou gastar $\mathbf{R} \$ 1.000$ por més, tendo um técnico que vai ficar no manancial trabalhando pro Consórcio, na proteçăo, orientando, vendo, sendo fiscal, sendo amigo dos caras lá, ajudando plantar, ajudando na manutençăo do manancial, porque o manancial faz parte do meu sistema produtivo de água. Entăo. Nós conversamos isso meses, dias, semanas, horas, a todo momento desse Consórcio, com o pessoal. E é difićlímo entrar na cabeça deles. Entăo depende da pessoa. (...)".

Ainda sobre o relatório do IPT, e as intenções de continuidade das ações no Forquilha, diz Almir:

"Se o IPT năo entregar tinha a incumbéncia da gente fazer isso. Olha, tá aqui o Forquilha. $90 \%$ reflorestado, aqui tem uma foto de uma criaçáo de porco, esse material do porco tá chegando aqui em baixo no reservatório. Tá sendo tratado, mas tá sendo um foco aqui. Aqui tem essa estrada, que tem uma erosăo vindo pra cá. No diagnóstico que fizemos, os principais problemas săo esses, tem aqui os tomateiros aqui, que mudam de figura mas esses agrotóxicos - tamo analisando, tamo analisando sedimentos - tăo chegando lá. Isso aqui hoje năo tem problema, porque tá tratando, mas se for acumulativo tem uma projeçăo... como é que nós podemos resolver? Entăo, pra isso nós lamos chamar a comunidade, chamar os produtores, mostrar isso pra poder ter uma legislaçăo, um condomínio, das pessoas assumirem aquilo alí, da cidade levar, por exemplo, as crianças pra ver aquilo lá e se orgulharem da cidade estar preservando aquele manancial. Os proprietários (vistos como os que) cuidam.(...) Agora , é o que eu to dizendo: ta feliz com tudo isso, mas só no bonzinho năo vai ser solucionado. Só no bonzinho năo sai. A tendéncia da pessoa é năo sair. A năo ser que a pessoa seja aqueles pontos fora da curva, que săo pessoas que tem um impeto, entende, aquele que mostra pro filho o que quer, aquele que vai fazer, que tem uma propriedade de certa maneira grande, que já abriga aquele bosque. É como sáo aqueles que tăo procurando ecoturismo, fazendas que tăo recebendo turismo, diversificando".

\section{Ed) Mário}

Atual Prefeito de Valinhos, e presidente do Consórcio, é político prestigiado na regiăo e já se envolveu no passado com a administraçăo da cidade, trazendo idéias inovadoras em tratamento de esgoto, cujas obras sofreram interrupçőes na gestăo seguinte. De volta à prefeitura, é um entusiasta na nova estrutura de planejamento preconizada pelos Comité e Consórcio. Defende abertamente a necessidade de se criar um 
Agéncia de Bacias, que administraria os recursos arrecadados pela cobrança pelo uso da água.

\section{Ee) Edison}

Ex-coordenador do programa de educaçăo ambiental Semana da Agua, Edison inspirou-se no modelo pedagógico francés (maieltica), que provoca a reflexăo e busca nos alunos e professores agentes multiplicadores na preocupaçăo com os recursos hídricos. O programa envolve Secretarias de Ensino, prefeituras, empresas, universidades, através da promoçăo de um calendário de atividades anuais que envolvem desde a preparaçăo dos professores (monitores), foruns de avaliaçăo das atividades do ano anterior, até o realizaçăo da semana propriamente dita (eventos escolares integrando os participantes). Também defende, dentro do programa, a importância da criação da Agéncia, e deixa transparecer a crença na necessidade de que os professores propaguem essa idéia junto aos alunos e pais. É um programa que provoca as crianças e jovens numa linguagem atual e de fácil compreensão. Preza pela continuidade das atividades anualmente, para que se possam esperar resultados futuros concretos em termos de mudança de mentalidades, frente ao ambiente, como ampliaçăo da responsabilidade dos cidadăos. Sua leitura da problemática ambiental na bacia do Piracicaba e Capivari é integrada, e tem densidade crítica. Năo aborda a realidade rural nem critica o sistema económico (e sua lógica) como possível contribuinte da crise, embora já tenha levado turmas de alunos até o Forquilha (propriedade de Mateus), e pressione empresas a colaborar com o programa. Tém insistido pela pela maior participaçăo de Sérgio em palestras sobre reflorestamento ciliar junto à Semana. Sua criticidade e dedicaçăo à área educacional (comunicativa, provocativa) contrasta com a auséncia destas dimensठ̌es no programa-irmăo, de proteçăo aos mananciais. Este último é encarado como punitivo, enquanto que a Semana da Água tem caráter educativo-preventivo.

\section{CESP}

\section{Ef) Ester}

Năo quis se pronunciar a respeito.

\section{Fundação Florestal}

\section{Eg) Jonas}

Jonas năo se envolveu com a comunicaçăo com os proprietários do Forquilha. Seu nível de atuaçăo era voltado ao apoio à estruturaçăo do viveiro de mudas da Prefeitura de Capivari, e numa segunda etapa, no fomecimento de sementes (quando a CESP năo mais fomecia mudas prontas para o plantio).

Durante o seminário "Implantaçăo de florestas e sua interface social: o estado da arte", Jonas (técnico da Fundaçăo Florestal, responsável direto na parceria com o Consórcio em Capivari) descreve: "Em Capivari, num trabalho de três anos foram plantadas 
109.906 mudas. Teoricamente faltariam 16.848 mudas a plantar, mas pela alta mortalidade faltam cerca de 50.000". Dessa informaçăo, calculamos uma mortalidade em tomo de $30 \%$, o que está de acordo com os dados apresentados por Sérgio (atual coordenador do programa, do Consórcio) , em visita técnica à microbacia do Forquilha em 30/07/97. Na ocasiăo, Sérgio associava à falta de manutençăo dos proprietários a maior causa dessa elevada mortalidade. Porém Jonas (tanto no seminário citado quanto na ocasiāo da visita técnica) acrescenta outros fatores: 0 atraso da prefeitura de Capivari no fornecimento de insumos como terra e esterco, a morosidade do Consórcio, a pouca participaçăo dos proprietários, e o atraso da própria Fundação Florestal na liberaçăo de sementes ao viveiro municipal de Capivari. Em termos gerais, Jonas avalia o processo como "grande desencontro": mudas prontas no periodo da seca, desperdício de recursos e falta de planejamento. Mais recentemente, a FF vêm buscando respostas às dificuldades relativas à adoçăo (espontânea) de esséncias florestais nativas pelos proprietários rurais, o que na época dos trabalhos no Forquilha, ainda năo era considerado importante.

\section{Promotoria de Justiça do Município de Capivari}

\section{Eh) Promotor de Justiçal Curador do Meio Ambiente de Capivari}

Dr. Marcelo é promotor de justiça de Capivari. Conta-nos a história da criaçåo da curadoria do meio ambiente, onde já começamos a compreender a herança em geral os promotores trazem no seu modo de agir, da área penal. A partir de 85, o Ministério Público passou a atuar em várias frentes, entre elas a ambiental.

Ele se mostra grande defensor da qualidade ambiental, e já fazia levantamentos no Forquilha antes da presença do Consórcio. Considera que a regiăo "está exposta à degradaçăo ambiental em decorréncia da sua atividade principal que é a exploraçăo da cana-de-açúcar". Cita duas fontes de degradação associadas à cana: a ambição dos proprietários de abocanhar cada vez mais terras para a cana, retirando as matas, e o próprio sistema de produçăo da cana, no que diz respeito ao fogo (que escapa do controle e queima as matas).

Quando chegou a proposta do Consórcio, ele a recebeu como uma parceria que viria a contribuir com seu próprio trabalho de levantamento e recuperaçăo.

Diz que tem procurado năo agir com excessivo rigor, quando verifica que os danos ambientais săo ou foram causados por pessoas "de pouca escolaridade", "pouca leitura", "gente simples", "ignorante", "principalmente os mais antigos".

Descreve assim o processo:

"Pois bem, voltando a falar a respeito do Consórcio e no trabalho desenvolvido lá no ribeirăo Forquilha, na microbacia, o pessoal do Consórcio - pelo que o senhor sabe, imagino eu - fez um trabalho de linha de frente, conversando com cada rurícola, com cada agricuttor, procurando a aceitaçăo espontânea por parte deles, do trabalho que o Consórcio estava disposto a implantar, ou desenvolver na regiăo...Enfim, todos os rurículas da microbacia foram contactados e - salvo engano -, todos aceitaram 
espontaneamente o trabalho desenvolvid o pelo Consorcio, ou aceitaram o trabalho que - Consórcio iria desenvolver. E a cada aceitaçăo o Consórcio firmava um documento a respeito. Entăo o Consórcio já se muniu de antemăo de documentos, năo é, e depois do contato inicial com os rurícolas, o pessoal do Consórcio colhia a assinatura de cada um..."

Dr. Marcelo parece năo se dar conta da estratégia de coerçăo necessária para que os proprietários assinassem os termos (da qual ele próprio faz parte), considerando as adesర̄es "espontâneas":

"Pois bem, no caso lá da microbacia - lembre-se que eu the disse que todos aderiram e se prontificaram a aceitar ou a acompanhar ou dar colaboraçăo ao trabalho do Consórcio."

Continua:

"Com esse material eu pude fazer um acompanhamento do trabalho desenvolvido pelo Consórcio, tá. Entăo eu fiquei como que um soldado de reserva, ou... fiquei...um tanto quanto afastado, năo é, do trabalho do Consórcio, mas fazendo essa fiscalizaçăo, tá, principalmente no que respeita ao cumprimento das obrigaçðes assumidas pelos proprietários, tá certo? A maioria dos proprietários das áreas do Forquilha cumpriram o prometido. Em síntese: eles concordaram em deixar de explorar determinadas áreas que haveriam de ser reflorestadas - como foram - concordaram e cumpriram depois a promessa de cuidar das mudas lá plantadas, repor aquelas que pereceram...enfim, a maioria dos proprietários da área lá da regiáo, cumpriram o prometido; colaboraram espontaneamente. (...) Agora com relaçăo à aqueles que deixaram de cumprir o prometido perante o Consórcio, eu instaurei um inquérito civil em relaçăo a cada um."

O inquérito civil existe para que "sejam concatenadas ou concentradas todas as informaçס̋es sobre determinado assunto, né, e no caso nosso seria o dano ambiental, pra que depois eu possa com base no inquérito e com base nas informaçठ̌es nele contidas, né, ajuizar uma açăo perante o poder judiciário, né, contra a pessoa que causou dano ambiental".

Entăo... "Aqueles que năo cumpriram, entăo com relaçăo a cada um eu instaurei um inquérito policial pra ver caso por caso. E fui convocando aqui à promotoria, esse pessoal pra tentar uma soluçăo aqui na promotoria, do caso, de maneira a evitar uma demanda, de evitar uma açăo com base nesse inquérito, ou nesses inquéritos instaurados."

Nesse encontro, individualmente, utilizou-se novamente a estratégia de coerçăo:

"(...) e o ajuizamento de um processo, de uma açăo, é extremamente desgastante, por motivos óbvios, né, para a pessoa. Primeiro porque vai ficar com o nome já manchado aí... vai ter o nome num distribuidor, e isso pode ter implicaçăo em financiamentos, por exemplo, né. Se um banco exigir uma certidão do distribuidor e tiver o registro de uma distribuiçắo, de uma açăo, isso já vai causar um transtomo à pessoa. Mas enfim, além disso, tem que contratar advogado, tem que vir aqui diversas vezes ao Fórum, com o risco de ser condenado, com um ónus muito grande, né. Além de multa, de indenizaçóes e de pagamento das custas, né, entăo ele, teria, vamos dizer, todos esses inconvenientes ante 0 ajuizamento de uma açăo. E mostrando esses inconvenientes, eu consegui - em muitos casos - que a pessoa, através da promotoria 
cumprisse o que havia prometido ao Consórcio. Agora entăo com mais firmeza, né, porque ela tem a possibilidade de ser processada, a pessoa já năo ficava tăo à vontade pra deixar de cumprir o prometido".

Dr. Marcelo entende que a utilizaçăo da faixa de mata ciliar (o ato ilícito) é muito antiga, e que reflete a pouca informaçăo dos proprietários sobre a proibiçăo do uso de tal área.

"Por isso que eu digo entăo que o ilicito é precedente... ele antecedeu a minha chegada em Capivari e a atuaçảo do Consórcio, tá. Como sanar esse ilícito, ou como resolver... ou como afastar esse ilicito? Entăo, eu bem poderia, logo de imediato, sem esperar que o Zé da Silva cumprisse o prometido ao Consórcio, eu poderia de imediato já processé-lo, entendeu? A lei viabiliza, ou me viabilizaria essa atitude de já... teria em măos o nome do proprietário, teria em mãos o dano ambiental havido... que mais me restaria - tecnicamente falando - pra ajuizar uma ação? Nada. Entăo eu poderia processar de imediato o sujeito, ou o nosso 'Zé da Silva', năo é. Mas, levandose em conta, justamente, a falta de dolo, a pouca leitura do rurícola, eu tive essa postura de esperar que tudo se resolvesse espontaneamente. Porque, também, a 'ferro e fogo' os efeitos nåo sáo satisfatórios, quase sempre, né. Bom, eu aguardei que o pessoal lá cumprisse o prometido, e em relaçăo à aqueles que năo cumpriram eu passei entăo a atuar na linha de frente..."

"(...) eu passei a trabalhar com os inadimplentes: com aqueles que deixaram de cumprir o que prometeram. Dentro desse grupo, um número grande de agricultores de submeteram aos acordos que eu lhes propus aqui na promotoria. $E$ por conta desses acordos firmados aqui na promotoria, eu arquivei os inquéritos correspondentes, tá. $E$ restou uma minoria que, enfim, năo cumpriu o prometido, perante o Consórcio, năo se submeteu a um acordo aqui, e pra que o caso năo ficasse sem soluçăo eu acabei ajuizando uma açăo em relaçăo a cada um, uma açăo civil pública. E os objetivos dessas açס̋es? Os objetivos de todas elas foram: primeiro, obrigar 0 agricultor a reparar o dano ambiental havido - e a reparaçăo se fez ou está se fazendo através do plantio de mudas."

Nesse contexto, percebemos que năo cabiam mais reflexర̋es sobre as possiveis falhas técnicas por parte da equipe do programa, ou o impacto dos plantios frente ao modo como os proprietários viviam, ou sobre o rompimento de acordos inicialmente estabelecidos e depois revistos ela equipe (erro de projeto na propriedade de Cláudio), ou preocupaçåo quanto à revolta que se fomentava no proprietário diante dessa situaçăo. Existia apenas o fato de ilegalidade (o uso da faixa ciliar), ratificado pela vistoria de Antonio, que coagiu à assinatura de um termo de compromisso de revegetaçăo, que năo tinha sido cumprido nos termos assinados (área, prazos, manutençăo ou completamente), que no Fórum năo aceitou o 'acordo' proposto, e que agora estava sob uma açăo civil pública, que os obrigava a fazer tal o plantio, e a cada atraso no prazo estabelecido deveria ainda pagar multa através de um plantio adicional.

Confirmando as impressర̃es de um dos proprietários entrevistados, quando falava que os plantios serviam para garantir que eles năo voltariam a usar as áreas, vemos de forma mais clara o objetivo triplice do programa: 
"E... entăo săo esses os objetivos: reparar o dano, se abster de explorar a área, e cuidar pra que as mudas plantadas se desenvolvessem, ou se desenvolvam, até se tomarem auto-suficientes."

A seguinte informaçăo apresentada pelo Dr. Marcelo, no contexto ainda do dano ambiental causado pelos proprietários rurais, nos faz pensar de novo nos $98 \%$ de esgoto de toda a bacia do Piracicaba e Capivari que é despejado nos rios sem qualquer tratamento:

"Eu tenho aqui em măos a lei 6.938 de 81. Ela dispõe sobre a Politica Nacional do Meio Ambiente, seus fins e mecanismos, e formulaçăo e aplicaçăo e dá outras providências. Dentre os dispositivos, dentre os artigos dessa lei, tem um que diz o seguinte: 'o poluidor que expuser a perigo a incolumidade humana, animal ou vegetal, ou estiver tomando mais grave, situaçăo de perigo existente, fica sujeito à pena de reclusăo - quer dizer, cadeia - de um a três anos, e multa. A pena aumentada até o dobro se resultar, dano irreversível à fauna, flora e ao meio ambiente (...)"

"Agora, mais especificamente na área ambiental, lá da microbacia... Lá, em inúmeros casos ficou caracterizada a contravençăo prevista na lei 7.803 de... ou melhor...4.771 de 65 que é justamente o código florestal. Contravençăo é, assim como o crime, uma infraçăo, o senhor entendeu? Só que uma infraçăo de menor potencialidade ofensiva".

"E o código florestal ele traz também um rol de contravençőes, que, enfim, estăo afetas à área penal. E lá na microbacia, inúmeras contravençőes se caracterizaram. O senhor sabe que o código florestal, com a alteraçăo dessa lei...feita pela lei 7.803 , ele... o código florestal ele prevé as áreas de preservaçăo permanente. Isso é do conhecimento do senhor. Entăo toda vez que a área de preservação permanente - ou essas faixas que devem ser preservadas - năo săo respeitadas, o fato caracteriza uma contravençăo, a dar ensejo à atuaçăo da polícia civil, certo? De maneira que, lá no caso da microbacia, eu alertava as pessoas que vinham aqui para esse fato também, que apesar do fato de muitas terem agido sem dolo, sem consciência de que estavam praticando uma infraçăo penal, vamos dizer assim, eu fazia esse alerta, que tinha essa conotaçăo também, e que poderia sujeitá-la - a pessoa, né - a um inquérito policial pra apurar o ocorrido, com os desgastes também que 0 inquérito policial proporciona. Diante dessa perspectiva de também ter que responder a um inquérito policial (...), diante dessa possibilidade de responder aum inquérito policial, entăo essa pessoa também... ou as pessoas... mais facilmente - entre aspas, né - se sujeitavam a um acordo aqui na promotoria, pra evitar maiores dissabores. Quer dizer, indiretamente, eu reconheço que exerci uma certa pressăo pra que as pessoas colaborassem, pra que o trabalho lá do Consórcio se ultimasse, né; fosse concluído. Mas vejo que foi um tipo de pressăo salutar. Primeiro porque poupou muitos de açóes civeis e criminais, poupou o trabalho do judiciário, poupou despesas, e nada mais fiz também do que passar às pessoas, ou àqueles que vieram aqui, a realidade jurídica. Quer dizer, mostrando que, năo teriam como se esquivar, de uma açăo na área cível, e teriam o risco de também, sofrerem uma açăo na área criminal, na área penal. De maneira que, enfim, o trabalho lá foi se desenvolvendo, e existem al algumas açōes em pendéncia ainda... em tramitaçăo... mas no geral, me parece que tudo transcorreu satisfatoriamente de forma a cumprir os objetivos do Consórcio, né. Faz algum tempo que eu năo tenho contato com o pessoal, pra saber se ainda existe algum agricultor, algum proprietário lá, 
renitente ou que năo esteja cumprindo o que prometera. Mas pelo tempo decorrido, me parece que, bem dizer, o trabalho já esteja concluído, as árvores já estejam autosuficientes, sem precisar de reposiçăo. Mas ainda eu vou entrar em contato com o Consórcio, pra ver se permanece ainda ałgum agricultor lá que precise ser acionado, que precise ser contactado."

Assim, fica claro o esquema de pressảo desenvolvido pelo promotor e pela equipe do Consorrcio.

E năo acabou ainda (fevereiro de 98), pois agora, se năo for até o fim, pode se configurar prevaricaçăo do Ministério Público:

"Então periodicamente, eu tenho expedido ofício ao Consórcio pra saber como é que está sendo cumprido o acordo referente a cada agricultor, né. E dependendo das respostas, é que... al eu tomo uma providéncia pra cada caso."

Segundo os levantamentos do Antonio, existem 14 proprietários (dos 27 da microbacia) ainda sob processo.

Papel do DEPRN:

"Agora, em outros casos, que năo lá, do Consórcio: entăo toda vez que eu verifico o dano ambiental, principalmente relacionado à invasăo ou exploração de área de preservaçăo permanente, eu tenho feito o seguinte: primeiro eu aciono o DEPRN - que tem se mostrado também muito eficaz nessa área. Eu aciono o DEPRN e quando assim eu faço eu mando um questionário, pra que o DEPRN responda. $E$ as respostas me servem pra eu embasar depois, de for necessário o processo, uma açăo civil pública. Entåo, eu sempre vou precisar de um trabalho técnico, pra eu trabalhar, pra eu atuar. Porque eu preciso depois de ajuizada a açăo, sustentar em juizo que ocorreu o dano, o dano ambiental. Porque somente uma pessoa ligada à área ambiental é que pode asseverar ou afirmar que aconteceu esse dano."

Danos associados à exploraçăo da faixa de mata ciliar

"(...) Houve um dano relativo à flora - o que me parece até óbvio, né - explorando a área de preservaçăo permanente, a vegetaçăo deixou de se desenvolver e consequentemente, a flora ficou prejudicada. Eu argumentei - e argumento também que houve também dano à fauna, por que? Porque a supressăo de árvores, principalmente, impossibilita ou inviabiliza a procriaçăo de espécies. Tenho argumentado também, risco à saúde pública. Por que? Porque a área de preservaçăo permanente - insisto em dizer, falando lá da microbacia, né - a área de preservaçăo permanente (APP) năo respeitada, isso possibilita, ou vinha possibilitando, năo é, que defensivos agrícolas, agrotóxicos acabassem indo ao curso d'água, e dali à represa Milhă... e consequentemente a populaçăo capivariana... quer dizer, mais um argumento. Mais um dano ambiental. E teve caso lá também de... existência de pocilga na APP, quer dizer... já o risco à saúde pública bem maior. Porque a pocilga, em contato ali com o curso d'água e consequentemente com a represa, colocava em risco - inegavelmente, năo é - a saúde da populaçăo. Pode ser um risco remoto, até por causa da dimensăo do... da represa, também em face do tratamento que a água sofre, antes de ser distribuida à populaçăo. Mas năo deixa de haver - ou năo deixava de haver - um risco. Quer dizer, entăo quando eu falo em dano ambiental, eu procuro averiguar - e pra isso também se presta também o inquérito civil, né - a extensăo desse 
dano. E pra eu obter uma sentença favorável - pra que o dano seja reparado pela pessoa acionada, eu preciso demostrar esse dano. E as vezes - bem dizer, de regra - a demonstraçắo desse dano só pode ser feita através de técnicos, que possam fazer uma avaliaçăo mais aprofundada dos reflexos daquela atividade, em determinada regiăo, determinada área, os reflexos ambientais nefastos."

Portanto, análises da água săo importantes, o conhecimento científico sobre os impactos das atividades nos recursos hldricos săo importantes, e a avaliaçăo dos riscos das atividades são importantes. Dois aspectos: um, comparativo às áreas urbanas degradadas (mesmo Capivari, que trata $0 \%$ de seu esgoto), onde já se conhece a qualidade da água (através de análises), já se tem avaliaçăo do impacto das atividades do entomo (como as indústrias de tintas em Americana) e já se conhecem os riscos pelos parámetros anteriores, e a carga poluidora continua sendo lançada todos os dias, impunemente. O segundo aspecto, refere-se ao fato de năo existir análises da qualidade da água da represa do Forquilha que abastece a cidade, năo se conhece os impactos das diferente atividades agropecuárias que vinham sendo desenvolvidas nas faixas de mata ciliar, nem tampouco seus riscos à saude da populaçăo capivariana. Estamos cada vez mais convencidos do que nos disse Ronaldo: a questăo é essencialmente política; e como 'sopa quente se toma pelas beiradas', o resgate da qualidade ambiental parece estar sempre dando seus primeiros passos sobre as cabeças dos cidadăos menos informados, menos organizados, menos capitalizados.

Também nesse contexto da legislaçăo fala-se a língua do capital: indenizaçőes em dinheiro (apenas como ameaça, a serem convertidas em plantios), multas para o caso do cronograma năo ser obedecido (idem), taxas pagas para cada audiéncia no Fórum, revistorias (para informar o promotor) cobradas dos proprietários.

Sobre a conciliaçăo entre o uso ou exploraçăo económica da faixa ciliar e sua conservaçăo, Dr. Marcelo acredita no turismo (associado à educaçăo ambiental) como uma boa opçåo.

Conclui dizendo que ele mesmo ajuizou açőes contra as prefeituras de Rafard e de Capivari por lançarem o esgoto in natura no rio Capivari. Estăo em andamento.

\section{Casa da Agricultura - CATI}

\section{Ei) Márcio (Capivari) e Otávio (Piracicaba)}

Agrónomo da Casa da Agricultura de Capivari, Márcio lamenta que os contatos com o Consórcio năo tenham se perpetuado. Forneceram ao Consórcio alguns mapas e de um levantamento da microbacia (Plano de Manejo, de 1991), e essa foi a única cooperaçăo entre as instituições. Tal levantamento năo revela o método nem disponibiliza os dados, mas afirma sérios impactos que estariam ocorrendo na microbacia em termos de queimadas, erosăo, contaminaçăo de mananciais e assoreamento da represa. 
Otávio, engenheiro agrônomo da Casa da Agricultura de Piracicaba, que esteve envolvido na elaboraçăo daquele levantamento em 91 , năo soube esclarecer esses dois pontos (método e fonte de dados).

A importância desse levantamento está em alguns preconceitos em relaçăo aos proprietários que năo se encontram justificados, mas que influenciaram a visăo da equipe do Consórcio no desenvolvimento das açठes (por exemplo, a imagem de degradadores, sem sensibilidade para as questōes ligadas ao ambiente).

\section{Serviço Autônomo de Água e Esgoto de Capivari (SAAE)}

\section{Ej) equipe administrativa e técnico de laboratório na ETA}

Tomei conhecimento de que a represa da fazenda milhă (da microbacia do ribeiråo Forquilha) abastece $30 \%$ da populaçăo de Capivari, que a água do rio Capivari năo é utilizada devido à sua alta carga de poluentes. A água vem por gravidade até a estaçăo de tratamento. Năo se tem análises da qualidade da água desta represa, embora 0 quimico da ETA I avalie como aparentemente ótima.

Fator de contradiçăo está no fato da ETA I năo funcionar das 24 hà 5 h da manhă, e despejar toda a água (sem armazená-la) direto no rio Capivari. Digo contraditória pelos argumentos colocados pela equipe do programa: uma de suas justificativas para a persuasão dos proprietários foi a de aumentar a quantidade de água na microbacia, sendo que alguns destes já sabiam daquela incapacidade de armazenamento, na cidade. Além do que a bibliografia relacionada nos diz que, em certas circunstancias, a vegetaçăo na faixa ciliar pode até reduzir a quantidade de água (pelo maior consumo), fato este levantado superficialmente por um ou outro proprietário, em suas observações ao longo dos anos.

E também a informaçăo de que $0 \%$ do esgoto de Capivari é tratado, ou seja, $100 \%$ jogado in natura no rio Capivari, à semelhança do que ocorre com muitos dos municípios que compóe as microbacias dos rios Capivari e Piracicaba.

\section{DEPRN}

\section{Ek) Valdir (Piracicaba) e Sônia (Coordenadora Geral da regional de Campinas)}

Os laudos oficiais do trabalho de Antonio (que incluia levantamento fotográfico das áreas) deveria, oficialmente, estar com o DEPRN, mas desapareceu.

Valdir foi o contato da instituiçăo na parceria com o Consórcio. Desconhece a realidade sócio-económica e ambiental da microbacia. Apenas cumpriu sua obrigaçåo, de oficializar os laudos (para encaminhá-los ao promotor, Marcelo), os termos assinados pelos proprietários e colaborar no cálculo das multas adicionais aos que năo cumpriam 
os prazos "acordados", convertendo-as em áreas adicionais de plantios (como informou Antonio).

Sônia, que acompanhou o programa à distância, adverte que, desde o inicio, năo houve qualquer pretensảo de que as açőes no Forquilha fossem educativas, embora considere importante tal preocupaçăo/ avaliaçåo. 


\section{Anexo C}

\section{Roteiros de entrevistas}

Com os Proprietários Lindeiros, na Microbacia do Ribeiråo Forquilha, Municipio de Capivari (SP)

(Obs: as perguntas serviram de guia para a entrevista semiestruturada. Năo săo portanto 'fechadas')

Apresentaçåo

a. Agendar, corvite (inclusive espose e filhos) e deixar documento

b. quem sou, meu tema, por que aqui

c. minha metodologia (alguns dos $28 / 31$, em duas semanas, sem nomes, gravar ou anotar, importantíssima a sinceridade das respostas para uma boa avaliacăo)

d. minha contribuiçăo (valorizar/documentar a viş̊o que nâo foi considerada até entăo)

\section{A. Historico}

1. da familia na propriedade

De onde săo e porque vieram? Como era o contato com a natureza? O que o fez vir pra cál permanecer na microbacia? Como se deu a aquisiçăo da propriedade (herança, compra, etc)? Ražres da escolha da propriedade (beira do ribeiråo)?

2. microbacia (bairros Borba, Telê Bresciani, Milhã, Samambaia e Săo Femando)

a) Qual a história do ribeirăo forquilha? Como era e como é hoje?

b) Costumavam pescar, caçar, coletar produtos da mata?

c) Têm percebido alguma mudança (transformaçōes no ambiente):

i. Nos solos?

ii. com os peixes, pássaros, outros animais, matas?

iii. Na vegetaçăo nativa e mata ciliar?

iv. Nos córregos que abastecem o ribeirăo, e na represa de abastecimento de Capivari?

d) Quais săo, na sua opiniăo, as causas dessas mudanças?

e) Como é que as beiras dos córregos e do ribeirăo foram ficando sem vegetaçăo? (Quando isso se deu?)

f) Como tem sido feita a conservaçăo dos solos na regiăo (terraços, preparo do solo, cultivo em nível, excesso de água nos carreadores, bacias de contençăo)?

g) Conhece outra regiăo que tem história muito parecida com a daqui?

\section{B. Propriedade}

1. Nos últimos tempos, quais têm sido as maiores dificuldades que sua família enfrenta na propriedade?

2. Qual a principal fonte de renda?

3. Como såo tomadas as decisỏes, na família, sobre a propriedade?

4. Quais culturas/criaçరes vem sendo desenvolvidas e razoes na escolha destas (incentivos?)

5. Como vê a qualidade do solo de lá pra cá (erosăo? Fertilidade?). Histórico da produtividade e causas. 
6. Qual a importância da cultura da cana na sua propriedade?

7. Faz arrendamento pra usina? Quais as vantagens e desvantagens?

8. Gostaria de desenvolver outra atividade económica na propriedade? 0 que o limita?

9. que pensa do desenvolvimento da piscicultura aqui na microbacia?

10. De que modo vocẻs usam a água que tem na propriedade (pra beber ou higiene na residência, pra irrigaçăo, criaçăo, etc)?

11. que pensa da mata ciliar? Serve pra que? Tem outras idéias, sugestőes ou soluçőes? (imagine-se falando com ambientalistas e legisladores)

12. De que modo a mata ciliar protege os cursos d'água? Vocé vê isso realmente ocorrendo, na sua propriedade? Plantio na beira do rio resolve, como dizem?

13. Pra que serve a mata nativa e a fauna? Por que conservá-los?

14. Usam água de poços? Por que?

15. Tem nascentes na propriedade? Como elas estăo hoje (quantidade/qualidade)? 0 que ora e é feito nessa área de nascente?

16. Na sua opiniăo, de quem deveria ser essa água que está dentro de sua propriedade (direito)? E de quem deveria ser a responsabilidade sobre ela (dever)?

17. que pensa dessa faixa na beira do ribeirăo (mata ciliar)? De quem deveria ser a responsabilidade de preservá-la/plantá-la? (Se arrenda pra usina, como fica a questăo?)

18. que pensa da utilizaçăo de árvores na propriedade (fins múltiplos como sombra, frutos, atraçăo fauna, mourăo pra cerca, construçōes, lenha pra queimar, cabo de ferramenta, lazer pras crianças, quebra-vento, cerca viva, etc)

19. Já pensou em utilizar essa mata ciliar de algum modo (na propriedade mesmo ou para o mercado)? Vocès estăo de acordo com essa restriçăo? Tem alguma idéia que tornasse possivel conservar e usar ao mesmo tempo?

20. que vocés fazem aqui na propriedade, qual o impacto/interferência que pode ter nas propriedades ao redor?

21. Que se pode fazer na área mais acima da mata ciliar pra melhorar qualidade e quantidade de água do ribeirăo? Qual a importância disso pra você? (como usar os fertilizantes e corretivos sem que ocorra o carreamento destes para os córregos e ribeirőes? como preparar o solo para o cultivo sem que cause o assoreamento dos riachos, ribeirăo e represa? como usar defensivos sem polui-los?)

22. É bom estar/ter propriedade na principal microbacia de abastecimento de água de Capivari? Porque?

23. que sonha para a propriedade no futuro (próximos 2, 10 e 30 anos)? Como pensa em viabilizar tal sonho? De que modo árvores, animais e água podem contribuir pra realizaçăo desse sonho?

24. Recebe ou já recebeu alguma assisténcia técnica? De que tipo? (Como é a qualidade desse serviço?)

25. Que sugestőes teria para melhorar essa assistência técnica que vocé tem recebido?

C. Programa de plantio

1. Como foi que tudo começou? (Os proprietários apoiaram o programa? Como os proprietários se envolveram com o programa? Como a família recebeu esse "convite"?)

2. Qual foi o papel do sindicato? 
3. Participaram de alguma reuniăo promovida pelo programa? Como foi?(Houve esclarecimento sobre a legislaçăo (justificativas)?Houve esclarecimento sobre o problema ambiental na região?

4. Foi feito algum trabalho educativo com os proprietários? Os proprietários foram estimulados a discutirem entre si a questão? Havia uniåo suficiente pra isso? (organizaçoses locais)

5. que era o "Termo de Adesăo" e "de Cooperação"?

6. Como têm sido o relacionamento com o pessoal do programa, de 92 pra cá?

7. Vocé aderiu espontaneamente ao programa?

8. Fale sobre a manutençåo e replantio (se ocorreram) em sua propriedade? 0 que aconteceu/observou?

9. Com o que o Consórcio contribuiu e com o que voces tiveramtêm que arcar, nesse programa?

10. Desde que começaram os plantios, têm reparado alguma alteraçăo na quantidade de água na microbacia (ou na represa)? Têm melhorado sua qualidade? $O$ que você acredita que vai mudar com os plantios?

11. que pensa da legislaçăo, que proibiu o plantio na beira do rio ( $30 \mathrm{~m}$ no seu caso)? Sem a força/pressăo dela você teria participado do programa? Quem deveria ter resolvido essa questão dos plantio na faixa ciliar?

12. Quanto te custou o reflorestamento, no total (custo direto, måo-de-obra, cerca, abandono ao plantio)?

13. tratamento foi igual pra todos no desenvolvimento do programa? Houveram privilégios?

14. Vocé entendeu o modelo de plantio escolhido no programa? Saberia repetir esse plantio das árvores (o jeito de plantar e as espécies, mais adequados), se fosse fazer sozinho? Como é? Gostaria de saber?

15. Como deveria ter sido feito esse programa na sua opiniåo? (Que mecanismos/ facilidades deveriam existir pra que muitos outros proprietários da regiåo fizessem esses plantios de matas ciliares, sem precisar ser pressionados pela legislaçăo?)

16. que mudou depois do programa? Que conclusăo você tira dessa atuaçăo, com os plantios? Mudou alguma coisa no seu modo de pensar? O que?

A. Participaçăo na vida social/política local

1. Como o pessoal da cidade e regiăo vêem vocês aqui do Forquilha? (Comentários, mudança nos relacionamentos, etc). Algo mudou, com o programa?

2. Como é o relacionamento com os vizinhos? Tem alguma atividade que poderia sair melhor se fosse feita junto com eles? Discutem juntos os problemas individuais, tentam solucionar juntos?

3. Frequentam as escolas do bairro? E postos de saúde? Igreja? Armazéns?

B. Poderia me ajudar a entender as causas por trás dessas análises, feitas para a microbacia do Forquilha em 90 ? Estão corretas?

1. Os agricultores dessa região, dăo pouca atenção a preservaçăo dos recursos naturais renováveis, deixam de adotar práticas mecânicas e vegetativas de conservaçăo do solo, e usam inadequadamente os defensivos agricolas, conduzindo suas lavouras muitas vezes sem as técnicas requeridas

2. A populaçăo local năo teve a preocupaçăo de fazer a reposiçăo da vegetaçăo natural 
3. Aponta-se como causa da degradação na microbacia o manejo inadequado, o mau uso do solo (que pela sua natureza é de fácil degradaçăo)

4. A populaçăo local é de bom nível participativo e organizacional

5. Existe 0 uso indiscriminado do fogo e são feitas dernubadas de matas.

Em 92 (Ricardo e Romani,1992):

1. O programa gerou inúmeras resisténcias porque:
a. proprietários desconhecem legislaçăo
b. năo eståo conscientizados para a queståo ambiental
c. colocam o interesse económico acima da melhoria da qualidade de vida
d. estão descapitalizados

O que acha do termo "resistentes" usado pelo pessoal para aqueles que năo aderiram ao programa de plantio? Vocé foi um deles? Como é um proprietário "resistente"?

Outras mais gerais:

1. que acha do cultivo da cana aqui na região em relaçăo à degradaçăo dos recursos naturais locais que vem ocorrendo?

2. que acham de serem considerados os culpados pela degradaçăo de solos, água e matas da microbacia? Como tem se sentido/reagido diante disso?

3. proprietário, e os adultos de maneira geral, é muito cabeça dura quando se fala em mudar alguma coisa pra melhorar a qualidade ambiental, năo adiantando trabalhar de forma educativa. Tem que ser na base da pressăo da lei, se năo punir a gente năo sai do lugar. $\mathrm{O}$ que $0 \mathrm{Sr}(\mathrm{a})$ acha?

C. Como vocés vêem essas instituições (atuaçăo local):

Quais dessas iniciativas/instituiçőes contribuem mais com vocés, pra melhoria da sua qualidade de vida (ou saúde de sua empresa-usina), aqui na propriedade? Que colaboração tém dado? Tem ligaçăo com alguma delas? Que benefício isso traz? Ela teve alguma atuaçăo relacionada com o programa?

a) Universidade, pesquisadores em geral

b) Casa da Agricultura?

c) Consórcio Intermunicipal das bacias dos rios Piracicaba e Capivari?

d) Instituiçőes financiadoras (agéncias bancárias, Cooperativa de Crédito dos Plantadores de Cana da Regiâo de Capivari). Dão crédito para outras atividades que năo a lavoura da cana?

e) DEPRN, CESP, Policia Florestal, Fundaçăo Florestal, IBAMA, Secretaria do Meio Ambiente?

f) Cooperativa dos plantadores de cana de Capivari

g) Cooperativa de crédito dos plantadores de Cana de Capivari

h) Associação dos fomecedores de cana de Capivari

i) Sindicato dos trabalhadores rurais de Capivari - Fetaesp

j) Sindicato Rural de Capivari - Faesp

k) Sindicato dos Trabalhadores de Indústria do Açucar

l) Outros

D. Entăo, quais as causas de sua situação frente ao programa (hoje e no passado)?

1. Sob processo (faltou manutençăo) ou

a. faltou plantio 
b. faltou replantio

2. Totalmente implantado, e/ou

a. causas do sucesso

b. dificuldades/facilidades

3. Houve regeneraçāo natural da mata

a. observaçøes (crescimento, fauna, água, etc)

b. qual o significado/importância dessa regeneraçăo pra vocé (beleza, utilidade, estorvo, insignificante, etc)

E. Possível visita à propriedade para complementaçăo das informaçð̄es?

F. Perguntas a mim, e agradecimentos.

Roteiro básico (parcialmente seguido) da entrevista com Sérgio (Coordenador da Seção de Proteção aos Mananciais da Secretaria Executiva do Consórcio), dia 18/03/98, na sede do PED/SEMA, Piracicaba (SP)

1. Quando vocé assumiu o cargo? Quais suas experiências anteriores nesse campo?

2. Como vocé caracterizaria o problema ambiental nas Bacias do Piracicaba e Capivari (\%, nos degradadores)? E as possíveis soluçőes? Qual a urgéncia dessas soluçőes; refletindo prioridades? Nessas possiveis soluçø̆es, qual o papel das massas populares? Cidadăo comum, agricultor, ...

3. Qual o papel (participação, \% aproximada) da mata ciliar na reversăo da problemática ambiental na bacia dos Rios Piracicaba e Capivari?

4. Como compatibilizar uma regiăo canavieira e altamente urbanizada como a dessas bacias, com a conservação de matas ciliares e a boa qualidade e quantidade dos recursos hidricos?

5. Qual o papel do poder público em tudo isso? Como avalia seu desempenho na luta pela qualidade ambiental da regiăo? 0 que tem feito o Consórcio em termos de cobrança do poder público daquelas que seriam suas atribuiçőes? Como foi e tem sido a cooperaçāo do Consórcio com ele, em Capivari?

6. Quais os objetivos do Consórcio?

7. Como foram decididas as frentes de trabalho do Consórcio? Prioridades? Quero entender como foi pensada a estratégia para enfrentar os problemas na bacia, conhecendo sua leitura da realidade (causas e medidas a serem tomadas)

8. Qual o orçamento do consórcio hoje e como é aplicado esse dinheiro (de 91 pra cá)? A. Consórcio, B. proteçăo mananciais e. C. Forquilha (\%) Histórico e luta pros recursos. Juntando o orçamento e prioridades que vem sendo tomadas. Como se encaixam?

9. Quais as fontes de recursos e as estratégias adotadas até então para ampliá-los?

10. Sobre os custos de vistorias e revistorias

11. Como surgiu essa separaçăo entre EA no trabalho do Chico, com crianças e adolescentes, e a auséncia desta no trabalho com os proprietários, usando entăo a legislaçăo? Por que năo a EA nos trabalhos de revegetaçăo ciliar? Faria alguma diferença? $O$ que pensa sobre educaçăo nesse trabalhos? Mais especificamente, educação de adultos? 
12. Como se estrutura sua frente de trabalho de proteçăo aos mananciais? Quais săo as atribuiçőes do Consórcio no programa de reflorestamento ciliar? O que compete a ele fazer?

13. Quais instituiç̧̋es estavam e estăo ainda envolvidas no programa de reflorestamento ciliar? (parcerias e atribuiçð̋es no programa) Quais as atribuiç̧̋es delas frente à sociedade, fora do programa?

14. Conhece o trabalho desenvolvido na microbacia do Ribeirăo Forquilha, desde 91 ? Como o avalia? Qual a importancia da avaliaçăo dos moradores/proprietários e de suas sugestóes? 0 consórcio está aberto a reformular as suas estratégias de açăo?

15. Como avalia os trabalhos e a metodologia no Forquilha?

16. Ainda existe o prazo pra recomposiçăo das matas (dois anos)? Por que năo a regeneraçăo natural? Da atual metodologia do programa, o que sai da sua cabeça e o que é determinaçăo da equipe ou necessidade política?

17. Quais as maiores dificuldades enfrentadas pela sua frente de trabalho?

18. O que mudou no seu trabalho desde o começo até agora, no modo de se pensar e fazer as coisas (avaliaçóes, valores, métodos, objetivos)?

19. No geral, quais seus próximos passos/desafios?

20. Qual o seu contato/como é sua comunicaçăo com os proprietários?

21. Como se dá a comunicaçăo do programa com os proprietários?

22. Quais as formas de avaliaçăo adotadas pelo Consórcio, frente às parcerias, proprietários e recursos hídricos?

23. Por que năo se permite a participaçăo dos proprietários enquanto sugestơes ao modelo (frutiferas)? Como eles poderiam participar?

24. Que outras metodologias de trabalho com reflorestamento ciliar vocé conhece?

25. Conhece a biblioteca do Consorcio? Costuma usá-la como apoio as suas decisర̋es? Em que se baseia (bibliografias, consultores, cursos) para as decisర̋es do dia-a-dia?

26. Como é o relacionamento entre os autónomos que vistoriam e vocé? Quais as recomendaçסes, diretrizes e metodologias acordadas, e como é feito esse acordo, se ele existe?

27. O que seria necessário para um trabalho articulado com as casas da agriculturas, nos moldes do Paraná, de valorizaçăo da participaçăo dos proprietários, com benefícios efetivos a eles? (um 'bom negócio')

\section{Roteiro para entrevista com Ester e Ronaldo}

1. Período e organizaçăo da equipe

a) De quando a quando atuou

b) Cargo e funçøes (o que fazia/atribuiçøes/responsabilidades)

2. Estratégias e Pressupostos da equipe

a) Como foi planejada/desenvolvida a estratégia de açăo nas bacias, tendo em vista a problemática geral (sistema Cantareira, tratamento de esgotos, industrias, monocultura)

b) Que critérios foram utilizados no processo de escolha de prioridades (como elegeram a proteçăo aos mananciais, matas ciliares)? Por que? Justificativas técnicas, 
políticas, operacionais? Porque revegetar a mata ciliar (aspectos técnicos), frente aos outros problemas?

c) Como avaliavam as causas da degradação na bacia Piracicaba e Capivari (cobertura florestal e água)? Quais critérios para escolha de Capivari, Sumaré, Nova Odessa, Cosmópolis?

d) Qual o caminho pra reverter a degradação na bacia?

e) Como era a comunicaçăo/relacionamento da equipe? (leituras, diagnósticos, decisőes, planejamento)

f) Porque năo começar pelas áreas institucionais das prefeituras p. ex., para ir puxando a açåo pelo exemplo, dando gancho para o trabalho de informaçăo/sensilibilizaçăo dos vizinhos, através de ação menos repressiva?

g) O que pensava sobre possíveis enfoques educativos? Cabiam na sua atuaçăo? Por que?

Quais as principais influências da Associaçăo de Defesa e Educaçăo de Maringá ADEAM que se verificam no programa: pressupostos, referenciais, publicaçðes, pessoas. Por que "foi a de metodologia mais adequada"? A açăo do ITCF nas vistorias (inspiração do modelo atual) teve melhores resultados? Lá, os proprietários eram apenas os "atingidos por barragem"? Como era o "apoio" dos produtores rurais?

3. Estratégias de envolvimento/comunicação com os proprietários

a) Qual sua postura (pressupostos e objetivos) I comportamento frente aos resistentes?

b) Como eram as reuniőes para "conscientizar os proprietários rurais da importáncia de se proteger e reflorestar as margens dos cursos d'água que são utilizados para o abastecimento público"? Assunto, metodologia... Havia pressão (muitas entidades como policia florestal ameaçando?) Tem registro ou documentaçăo?

c) Considera que as adesర̌es espontâneas existiram, mesmo com a evidente pressão (autoridades e leis) presente nas duas reunióes (tanto coletiva como individual)?

d) Os que năo aderiram espontaneamente, por que não o fizeram? Por que não se pensou em outras vias (trabalho educativo, p. ex.)? Nåo é um esquema de chantagem (o proprietário assina por que é a lei e se voce năo assinar não tem muda, projeto e nada de graça, vai ter ainda que pagar)?

e) $O$ que pensam os agricultores? Por que eles não fazem sem a força da lei?

f) Existem associaçóes de moradores/ proprietários (sindicatos). Como era a organização?

g) Quais objetivos/ funçðెes primordiais da mata ciliar? Como trabalhou cada uma delas na comunicaçăo com o proprietários (problematizando e ouvindo a construçăo lógica deles)?

4. Questionamento das estratégias

a) educaçăo de adultos

b) por que apelou-se para o uso da lei (promotoria)?

c) 0 que pensa de iniciativas de fortalecimento da participaçăo/organização comunitária como estratégias de combate à degradação ambiental?

d) Porque todos na microbacia tinham que assumir o compromisso do plantio e năo só os que inicialmente já queriam (efeito demonstrativo, manutençăo espontânea, maior sobrevivência das mudas, sem a força da lei, economia de recursos)? Nenhum queria?

e) Caberia um processo educativo, englobando p. ex. organizaçăo e fortalecimento comunitário, diagnóstico conjunto/participativo, reflexăo/problematizaçăo da evoluçăo 
histórica da degradaçăo, responsabilidades e co-responsabilidades, contexto da exloração económica da cana, os usineiros?

5. Esclarecimentos baseados no artigo:

RICARDO, E. P. R. \& ROMANI, S.M. A. Programa de Proteção aos Mananciais de Abastecimento Público nas Bacias dos Rios Piracicaba e Capivari. In: SEMANA DE DEBATES SOBRE RECURSOS HIDRICOS E MEIO AMBIENTE. (Etapa Piracicaba). Ed. Atas, Piracicaba, 1992. 213 p.

a) Entre as causas que voce levanta para as inúmeras resistências que surgiram no Programa está a mais geral: "desconhecimento generalizado da legislaçăo ambiental". Como situa a responsabilidade do Estado contribuindo para esse quadro, nos incentivos do passado recente à modelos de desenvolvimento e de ocupaçăo do território na bacia, hoje aceitos como degradantes da qualidade ambiental?

b) O "programa é inédito", "o desconhecimento da legislaçăo é generalizado", e a culpa é da sociedade apenas? Por que năo voltar mais o enfoque para a avaliaçăo da metodologia de trabalho adotada?

c) Explicar: "ausencia de uma conscientizaçăo da sociedade COMO UM TODO para questőes ambientais" (entăo já sabiam disso previamente?) - "interesses económicos acima da preocupaçăo com a qualidade de vida" (?) - "falta de recursos humanos e financeiros por parte das administraçöes públicas, municipais, estadual e federal" (entåo o programa poderia ter assumido esse recorte, sendo mais eficiente e de efeito multiplicador e de mais longo prazo) - "ausencia da iniciativa privada no apoio ao Programa" (como ela teria otimizado o programa?)

d) Sobre o aprimoramento da metodologia de trabalho, o que foi feito de lá pra cá? Em nível profundo (estrutural, de processos/objetivos /pressupostos ou pequenos ajustes nas estratégias?)

e) O que considera METODOLOGIA EFICAZ PARA EXECUÇÃO DO PROGRAMA? No estado de Săo Paulo? Por que?

f) Sobre os "incentivo a núcleos de EA" - como se desenvolveram?

g) Viveiros e mudas foram limitantes na primeira etapa?

h) Como curso de reciclagem para assessores e professores ajuda às limitações encontradas na primeira etapa?

i) Como eram os folders? Qual o principal objetivo deles, e como se encaixavam na estratégia de açăo (pressupostos)? Tem algum pra mim?

j) Poderia mapear ou me ajudar a fazer isso, em uma ou duas bacias onde atuou (açőes completas nas quais eu possa entrevistar os proprietários), com "causos" mais interessantes (gradaçăo entre os exemplares e os conflituosos)?

Roteiro da entrevista com o Promotor de Justiça/Curador do Meio Ambiente de Capivari, Dr. Marcelo (seguido parcialmente)

1. Sua história como curador do meio ambiente, formaçăo ambiental

Sobre a leitura ambiental

2. Sua leitura dos problemas ambientais na bacia (poluiçăo da água, escassez, florestas...) 
3. Como o Sr. acredita que se conseguirá preservar e resgatar os recursos hídricos e matas na bacia do rio Capivari? Quem mais contribui, infringindo a lei, para essa degradaçăo? Qual a situaçăo dos esgotos domésticos e industriais e da agricultura? (96\% dos esgotos municipais não săo tratados na Bacia do Piracicaba).

4. Quais os fatores de degradaçăo no Forquilha? Como é o processo e como que os infratores contribuem? Erosăo, poluiçăo, contaminaçăo?

Sobre os processos (avaliaçăo da necessidade de agir e poder para pedir informaçőes)

5. Desde quando existem restrições ao uso da mata ciliar? (anterior ao código de 65)

6. Como tudo começou (Quais os instrumentos legais (caminhos legais). Como se chama? Porque aceitou? Existiam assessores técnicos para orientar a decisão? Critérios. Perícia foi restrita?

7. Que taxa é essa que os proprietários têm que pagar cada vez que vão ao fórum?

8. O que é a SOBRADIMA?

9. Teria sido possivel o resgate da qualidade ambiental sem a força da lei, no Forquilha?

10. Como se caracteriza a culpa dos infratores, o contexto de co-responsabilidade que gerou isso?

11. Existiu alguma possibilidade de defesa dos proprietários daquela microbacia?

Sobre o Fórum

12. Que taxa é essa que os proprietários têm que pagar cada vez que văo ao Fórum?

13. Por que săo cobradas dos proprietários as vistorias e revistorias, fotos? Năo é verba do Consórcio?

Sobre os proprietários

14. Como o Sr. caracterizaria os infratores nessa microbacia? Quem săo, quais seus motivos, por que năo plantam espontaneamente as matas ciliares? Como vivem, 0 que representa pra eles esses plantios em termos de modo de vida, economia da propriedade? Conhece-os?

15. Eles sabiam da lei ou de sua importancia? Eles podiam cumpri-la, sem pressăo?

Sobre os resultados

16. Sobre os resultados ambientais hoje, após 6,7 anos do inicio das açőes.

17. O que pensa do uso econo̊mico ou pra subsisténcia, da mata ciliar? E da reserva florestal?

18. Existe alguma ação voltada ao resgate da cidadania, dos diretos de cidadania daqueles proprietários (crédito, estradas, informaçăo, saúde, educaçăo)

19. Quando o senhor aplica com eficiéncia a lei, de forma setorizada, năo contribui para aumentar a injustiça?

20. A abertura de processo aos que nåo plantaram em 2 anos nåo é muito cómoda, frente à complexidade da organizaçăo social, tecnológica, histórica e económica do campo e a influência das instituiçőes públicas como prefeitura (estradas, saúde, educaçăo), casa da agricultura (informaçőes, assisténcia, crédito) SAEE (armazenamento de água, informaçăo), e comunicaçăo para elaboraçăo de programa integrado).

21. Nesse contexto, a lei colaborou para um papel educativo do programa? 
Sobre o programa (sugestőes para reformulaçăo)

22. Se esse caminho (da multa) deveria ser aplicado às administraçరes públicas e industriais. Resolveria?

23. Sobre a responsabilidade de manutençăo e zelo (fogo, furto, eventos naturais, erros técnicos). Como se baseia legalmente isso.

\section{Roteiro da entrevista com o pessoal do SAEE de Capivari}

1. Como vem sendo as chuvas nos últimos $\mathbf{5 0}$ anos?

2. Sobre o desperdício de água em Capivari. Por que?

3. Sobre 0 abastecimento com o rio Capivari

4. Sobre a possibilidade de manter um profissional em campo trabalhando e amarrando açőes que favoreçam a preservaçăo dos mananciais.

5. Sobre o envolvimento com o Consórcio

6. \% de água do abastecimento de Capivari que vem do Forquilha

7. Sobre o armazenamento de água (o sistema) e o desperdicio

Roteiro da entrevista com o coordenador geral da Secretaria Executiva do Consórcio (seguido parcialmente)

Almir

Geólogo (USP,71), mestre em Geotecnia (USP,84), especialista técnico da CESP, CoAutor de "A Luta pela Água nas Bacias dos Rios Piracicaba e Capivari" (Editora EME, Capivari, SP).

1. orçamento do consórcio desde sua criaçăo pra cá (anual). Como aplicou esse dinheiro? (\%)

2. Como está o orçamento hoje?

3. Quais as diretrizes dos trabalhos do Consórcio? Seus principios básicos que norteam as açőes?

4. Quais săo as atribuiçőes do Consórcio? O que compete a ele fazer?

5. Vocés năo assumem os custos das vistorias e revistorias?

6. Quais as fontes de recursos e as estratégias adotadas até entăo para ampliá-los?

7. Como foram decididas as frentes de trabalho do Consórcio? Prioridades? Quero entender como foi pensada a estratégia para enfrentar os problemas na bacia, conhecendo sua leitura da realidade (causas e medidas a serem tomadas)

8. Como resolver os problemas nas Bacias? Qual sua leitura da problemática geral e das possíveis soluçð̋es? Qual a urgéncia dessas soluçర̋es?

9. Qual a contribuiçåo do comité das bacias para essa problemática?

10. Nessas possíveis soluçరes, qual o papel das massas populares/ populaçåo rural e urbana?

11. Como compatibilizar uma regiáo canavieira e altamente urbanizada como essas bacias, com a conservaçăo de matas ciliares e a boa qualidade e quantidade dos recursos hídricos?

12. Quais as instâncias de decisăo? Secretaria executiva, presidente... 
13. Quais instituiçőes estavam e estão ainda envolvidas no programa de reflorestamento ciliar? (parcerias e atribuiçס̋es no programa) Quais as atribuiçס̃es delas frente à sociedade, fora do programa?

14. Como surgiram as áreas prioritárias? Como era o modo de decisăo

15. Onde se embasaram pras açőes de reflorestamento ciliar nas microbacias

16. Como se estrutura sua frente de trabalho de proteçăo aos mananciais

17. Porque năo se permitiu a participaçăo dos proprietários enquanto sugestões ao modelo (frutlferas)?

18. Qual o significado do prazo estabelecido pra recomposição das matas (dois anos)? Porque que năo a regeneraçăo natural?

19. Qual o papel (participaçăo, \% aproximada) da mata ciliar na reversăo da problemática ambiental na bacia dos Rios Piracicaba e Capivari? Na reduçăo da poluiçăo/erosăo, no aumento da quantidade de água, no aumento da qualidade da água?

20. que pensa sobre Educaçăo, nesses trabalhos? Mais especificamente, educaçăo de adultos?

21. Como surgiu essa separaçăo entre EA no trabalho do Chico, com crianças e adolescentes, e a ausencia desta no trabalho com os proprietários, usando a legislação? Por que năo a EA nos trabalhos de revegetaçăo ciliar? Faria alguma diferença?

22. Quais as maiores dificuldades enfrentadas por esta secretaria?

23. que vem mudando no modo de se fazer as coisas nessa Secretaria, da sua criaçăo até hoje?

24. Quais os próximos passos/desafios?

25. Quais os maiores contribuidores do quadro de degradação nessas bacias?

26. Em termos gerais ,qual a contribuição (\%) de cada um? (da atividade agropecuária, das residências nas cidades, das indústrias)

27. Juntando essa análise, ao orçamento e prioridades que vem sendo tomadas. Como se encaixam?

28. Conhece a biblioteca do Consorcio? Costuma usá-la como apoio às suas decisర̃es? Em que se baseia (bibliografias, consultores, cursos) para as decisర̃es do dia-a-dia?

29. Qual o papel do poder público em tudo isso? Como avalia seu desempenho na luta pela qualidade ambiental da regiăo? 0 que tem feito o Consórcio em termos de cobrança do poder público daquelas que seriam suas atribuiçס̋es? Qual o nível de cooperaçăo com ele? 


\title{
Anexo D
}

(Proposta apresentada ao Consórcio, em fevereiro de 1997)

\section{Universidade de São Paulo \\ Escola Superior de Agricultura "Luiz de Queiroz" (ESALQ) Departamento de Ciências Florestais}

\section{Plano de Dissertação de Mestrado em Ciências Florestais}

\section{Caracterização da Atuação Educativa de Açōes Institucionais Voltadas ao Reflorestamento Ciliar \\ (na bacia dos rios Piracicaba e Capivari)}

\author{
Mestrando: Eng. Agr. Marco A. S. Malagodi \\ Orientador: Prof. Dr. Marcos Sorrentino
}

\section{PIRACICABA}

fevereiro/97

\section{Justificativa}

Tendo em vista:

a) as dificuldades metodológicas educacionais que os técnicos, envolvidos com iniciativas de reflorestamento ciliar encontram no seu dia-a-dia;

b) o crescente número de projetos para a área ambiental que desejam trabalhar sob um enfoque educativo;

c) o apelo da comunidade científica, financiadores e público em geral para a necessidade de incorporação da educação ambiental aos projetos de conservação/recuperaçăo ambiental;

d) a pouca atençăo dada aos resultados educativos desses projetos e suas consequências à formaçăo e fortalecimento de cidadăos;

e) as polémicas presentes no encontro das áreas de Educaçăo, Conservação da Natureza, Extensão Rural e Direito Ambiental;

f) e a escassez de trabalhos de pesquisa na interface dessas áreas,

escolhi como tema de minha dissertaçăo de mestrado a questáo da atuaçăo educativa do profissional (executor, coordenador e/ou idealizador) que atua no contexto do reflorestamento ciliar.

\section{Breve histórico}


Durante o ano de 96, cursei disciplinas das áreas de economia, conservaçăo da natureza, e educaçăo ambiental, tendo oportunidade de me aprofundar nas discussర̌es com grupos e professores de cada disciplina, selecionando e recortando melhor o tema de interesse.

Inicialmente fiz um contato com a Casa da Agricultura de Assis, envolvida tanto com os Projetos de Execuçăo Descentralizada (PED), como com o Consórcio Intermunicipal do Escritório da Regiăo de Govemo de Assis (CIERGA) e com o Centro de Desenvolvimento do Vale do Paranapanema (CDV).

\section{Proposta para as instituiçōesfiniciativas relacionadas com o reflorestamento ciliar da bacia dos rios Piracicaba e Capivari}

Este trabalho de pesquisa se desenvolverá ao longo do ano de 97 (com previsăo de qualificaçăo para dezembro deste ano), e pretende conhecer melhor os objetivos, princípios, valores e metodologias por trás das açőes institucionais voltadas ao reflorestamento ciliar, de modo que em parceria com a instituiçăo, possamos caracterizá-la. Essa caracterizaçăo, sobre açóes passadas, atuais e futuras, permitirá uma análise mais profunda no campo educativo, oferecendo à instituição uma oportunidade de reflexão sobre suas eventuais limitações nessa área, para se desejar, melhor se preparar para transpô-las.

Também permitirá, juntamente com a caracterizaçăo das atividades de outras instituiçర̋es, que se entenda melhor: (i) o potencial educativo da legislaçăo ambiental vigente, (ii) a avaliaçăo desses programas pelo próprio público-alvo, (iii) a vontade/viabilidade de se atuar de forma educativa dentro desses programas.

Para tanto, essa pesquisa demandará apoio, cooperaçăo e eventual suporte para as diferentes etapas de seu desenvolvimento, esboçadas a seguir:

1. ETAPA - conhecimento geral do campo de atuação (da instituição) e seleção do campo de pesquisa

- visitas à coordenação do Consórcio e Comitê;

- mapeamento do campo de açăo da instituição;

- apresentação do plano de pesquisa

Uma vez aceito o plano de pesquisa, seguirá um co-planejamento, de pesquisador e coordenador(es) institucional(is), para maior sintonia e sincronia com o funcionamento da instituiçăo, divulgação do plano de pesquisa, e busca de parcerias com outros agentes.

2a ETAPA - envolvimento com a instituição, agentes, e programas

- consulta a documentos oficiais que descrevam ou indiquem açóes concretas no passado e presente, e acesso ao planejamento dos programas a serem implementados;

- entrevistas com os profissionais envolvidos;

- mapeamento das propriedades abrangidas na atividade;

- idas a campo para eventuais entrevistas com produtores/proprietários rurais;

$3^{2}$ ETAPA - trabalhos em grupos 
- reuniठ̋es para esclarecimento, aprofundamento e debate das informaçøes com os técnicos;

- grupo de trabalho sobre extensảo, legislação e educação ambiental;

- workshop final reunindo lideranças e representantes de vários setores envolvidos no contexto da pesquisa (técnicos, proprietários, pesquisadores, polícia florestal, DEPRN, coordenadores dos programas, educadores).

4. Referências e comunicação

Mestrando

Marco Antonio Sampaio Malagodi

Eng. Agronomo, CREA n5060343147, pela USPIESALQ, turma de 94.

Rua Pompeu Pompermayer 385, Vila Prezoto - Bloco 1, apto 114

13420-774 Piracicaba - SP

D (019) 426-3972

Orientador

Prof. Dr. Marcos Sorrentino - Educação Ambiental

Departamento de Ciéncias Florestais, USP/ESALQ

I (019) 429-4264 r.226

Co-orientadores

Prof. Dr. Oriowaldo Queda - Sociologia Rural

Prof. Ademir de Luca - Extensão Rural

Departamento de Sociologia e Economia Rural, USP/ESALQ

I (019) 429-4119

Prof. Dr. Paulo Y. Kageyama - Melhoramento e Plantio de Essências Nativas Departamento de Ciéncias Florestais, USP/ESALQ

8 (019) 429-4264 


\section{Anexo E}

Cadastro dos proprietários (1990) fornecido pelo técnico (Antonio) a serviço do Consórcio (projeto inicial de plantios e área a ser plantada)

Municipio: Capivari - Microbacia: Forquilha

$N^{\circ}$ ha: 81,37

$N^{\circ}$ mudas: 132.876

No proprietários: 27

\section{Emilio Angarten \\ Sitio Såo Martins \\ CIC \\ 716.765.038/020}

$\mathbf{N}^{\circ}$ de Mudas: 2000

Area: $1,8 \mathrm{ha}$

Natale Zumeinstein

Sítio Såo Fernando

CIC 129.727.038/04

$\mathbf{N}^{\circ}$ de Mudas: 2000

Area: 1,2 ha

Pedro Zumeinstein

Sítio Săo Fernando

CIC 129.727.388/53

$N^{\circ}$ de Mudas: 594

Area: 2,1 ha

Armando Bresciani Sítio São Pedro

CIC 127.261.928/00

$\mathrm{N}^{\circ}$ de Mudas: 5300

Area: 3,2 ha

Antonio Brunharo N. Sitio Såo Fernando

CIC 302.617.408/49

$\mathrm{N}^{\circ}$ de Mudas: 2500

Area: 1,5 ha

Silvio Brunharo

Sítio São José

CIC 129.744.478/72

$N^{\circ}$ de Mudas: 433

Area: 0,28 ha

Osvaldo Bertoldo

Sítio Santo Antonio

CIC 749.588.108/97

$\mathrm{N}^{\circ}$ de Mudas: 2540

Area: 1,47 ha
Antonio Pavan

Sítio Pinheirinho

CIC 619.726.068/91

$\mathbf{N}^{\circ}$ de Mudas: 1000

Area: 0,6 ha

Hamilton e Lorival Cibin

Sítio Santo Antonio

CIC 185.942.718/91

$\mathbf{N}^{\circ}$ de Mudas: 1666

Area: 1,0 ha

Ettore e Osmar Bresciani

Sítio Santo André

CIC 553.081.208/20

$\mathrm{N}^{\circ}$ de Mudas: 400

Area: 0,24 ha

Mário Domingos Pavan

Sítio Såo Fernando

CIC 129.733.948772

$N^{\circ}$ de Mudas: 700

Área: 0,42 ha

Joảo Batista Pavan

Sítio N. S. Aparecida

CIC 129.733.788/34

$\mathrm{N}^{\circ}$ de Mudas: 700

Area: 0,42 ha

José de Jesus Leite

Sitio Aranha

CIC 002.191.178/96

$N^{\circ}$ de Mudas: 4000

Area: 2,4 ha

Antonio Schincariol

Sítio Bela Vista

CIC 317.851.078/87

$N^{\circ}$ de Mudas: 9500

Área: 5,7 ha
Lázaro Madeira

Sítio Aranha

CIC 317.852.208/53

$\mathrm{N}^{\circ}$ de Mudas: 4000

Área: 2,4 ha

Alexandre Batagin

Sitio Progres. e Progressinho

CIC 127.417.018/49

$\mathrm{N}^{\circ}$ de Mudas: 6500

Area: 3,19 ha

Fernando e Romeu Batagim

Sitio Såo José e Progresso

CIC 164.064.788/00

$\mathrm{N}^{\circ}$ de Mudas: 11000

Area: 6,6 ha

Salvador de Jesus Bicudo

Sitio Aranha

CIC 164.020.938/04

$\mathrm{N}^{\circ}$ de Mudas: 9000

Area: 5,4 ha

Otávio e Joaquim da Costa

Sítio Retiro

CIC 129.732.548/68

$N^{\circ}$ de Mudas: 3000

Área: $1,8 \mathrm{ha}$

Hermes Maschietto

Sitio Forquilha

CIC 821.623.448/15

$N^{\circ}$ de Mudas: 1333

Area: 0,8 ha

Emani D. Gonzaga

Fazenda Santa Ana

CIC 014.581.758/04

$N^{\circ}$ de Mudas: 1100

Area: 0,66 ha 


Maria Aparecida
Pacheco Borba
Fazenda Santo
Antonio
CIC $966.686 .288 / 34$
$N^{\circ}$ de Mudas: 5830
Área: 3,5 ha
Indústria Açucareira
Såo Francisco SIA
CGC 9 Co
$47.756 .754 . / 0001-30$
$N^{\circ}$ de Mudas:
283000

Área: 17 ha

Uniáo Sáo Paulo S/A

Agricultura, Indústria e Comércio

CGC

$N^{\circ}$ de Mudas: 14750

Área: 8,85 ha

Matilde Dallara de Souza e

Alfredo Dallara

Sítio Novo

CIC 8.353.533

$\mathbf{N}^{\circ}$ de Mudas: 900
Área: 0,54 ha

José Aparecido Madeira

Sitio Sustein

CIC 821.641.348/34

$\mathbf{N}^{\circ}$ de Mudas: 5500

Área: 3,3 ha

Maria Aparecida C. Gonzaga

Pecheco

Faz. Milhă

CIC 244.790.631/63

$N^{\circ}$ de Mudas: 8330

Area:5,0ha 


\title{
Anexo F
}

Página entregue aos proprietários rurais e funcionário da usina, quando eram agendadas as entrevistas.

\section{Desenvolvimento rural, educação ambiental e matas ciliares}

\author{
Marco A. S. Malagodi
}

Eng. Agrónomo - CREA n` 50603431147 - pela Escola Superior de Agricultura "Luiz de Queiroz" (ESALQ), da USP, em 1994. Atualmente cursando Mestrado em Ciências Florestais na ESALQ/USP, Departamento de Ciências Florestais, sob orientaçăo do Prof. Dr. Marcos Sorrentino

Titulo (provisório) do trabalho

A dimensăo educacional de um programa voltado ao reflorestamento ciliar na bacia do rio Capivari

\section{Resumo}

O trabalho consiste em uma reflexăo sobre as possíveis contribuiçōes que um programa de reflorestamento ciliar trouxe, traz e pode vir a trazer para a construçăo de um novo modelo de abordagem da questăo ambiental na propriedade rural. Trata-se de um estudo de caso na microbacia do ribeirăo Forquilha, municipio de Capivari (SP), onde o Consórcio Intermunicipal das Bacias dos rios Piracicaba e Capivari vem desenvolvendo desde 92, em parceria com o DEPRN, Fundaçăo Florestal, Promotoria Pública de Capivari e CESP, o Programa de Proteçăo aos Mananciais de Abastecimento Público, através do reflorestamento ciliar. Tendo como pano de fundo os principios e orientaçōes para uma atuaçăo educativa que fortaleça a construçăo da cidadania como caminho para a recuperaçăo ambiental (Conferência de Tbilisi, Agenda 21, Paulo Freire, entre outros), a dissertaçăo analisa o encontro da legislaçăo ambiental, com a atuaçăo do técnico extensionista, as estratégias adotadas pelo Consórcio, os modelos de reflorestamento adotados, as limitaçőes institucionais, o histórico de desenvolvimento rural da regiăo, a importáncia da mata ciliar no atual contexto de degradação nas bacias.

\section{Contato}

R. Pompeu Pompermayer 385, Vila Prezzoto, Ap. 114

Cep: 13420-774. Piracicaba/ SP. 


\section{Referências Bibliográficas}

AMSTALDEN, L. F. F. Os Custos Sócio-Ambientais da Modernização Agrícola Brasileira. (Monografia). Campinas: IFCH/UNICAMP, 1991. 56 p. Ano I, n. 1.

ALMEIDA, J. A. Pesquisa em Extensão Rural: um manual de metodologia. Brasilia: MEC/ABEAS, 1989. 182 p.

BARBOSA, L. M.; BARBOSA, J. M.; BATISTA, E. A.; MANTOVANI, W.; VERONESE, S. A.; ANDREANI JR, R. Ensaios para estabelecimento de modelos para recuperação de áreas degradadas de matas ciliares, MojiGuaçu (SP) - nota prévia. In: SIMPÓSIO SOBRE MATA CILIAR, São Paulo, 1989. Anais. Campinas: Fundaçăo Cargill, 1989. p. 268-283.

BARBOSA, L. M. Estudos Interdisciplinares do Instituto de Botânica em MogiGuaçu, SP. In: SIMPÓSIO SOBRE MATA CILIAR, São Paulo, 1989. Anais. Campinas: Fundação Cargill, 1989. p. 171-191.

BARRANTES, M. T. (org.) Diálogo Ambiental em Comunidades Rurales: experiencias participativas de la OET. Ed. por Rodney Naranjo e José de la Guardia. San José (Costa Rica): 1a ed., Organización para Estudios Tropicales, 1997. $72 \mathrm{p}$.

BARROS, F. G.; MONTICELLI, J. J. Plano de Atuaçăo 95/96 e Balanço de Atuação e Orçamento 93/94. Americana: Consórcio Intermunicipal da Bacia dos Rios Piracicaba e Capivari, 1995. 26p. (Consórcio Intermunicipal da Bacia dos Rios Piracicaba e Capivari, ${ }^{\circ}{ }^{13}$ ) 
BARROS, G. P.P.; BOTELHO, N. M. A.; BRAGA, G. M. Açăo Pedagógica da Extensão rural: discurso e prática. Economia Rural, vol.3, $n^{\circ} 9$, p.26-28, julho/setembro, 1998.

BECKER, H. S. Métodos de Pesquisa em Ciências Sociais. $2^{a}$ edição. Săo Paulo: HUCITEC, 1994.

BERTOLINI, D.; LOMBARDI NETO, F.; DRUGOWICH, M. I. Programa Estadual de Microbacias Hidrográficas. Campinas: Secretaria do Agricultura e Abastecimento. Coordenadoria de Assistência Técnica Integral. 1993. 15p.

BORDENAVE, J. E. D. O que é Participação. $3^{a}$ edição. Săo paulo: Editora Brasiliense, 1985. 84 p. (Coleçăo Primeiros Passos)

BULL, D.; HATHAWAY, D. Pragas e Venenos: Agrotóxicos no Brasil e no Terceiro Mundo. Petrópolis: Vozes/OXFAM/FASE, 1986. 236 p.

CARVALHO, I. C. M. Educação, Meio Ambiente e Cidadania. In: CONGRESSO NACIONAL SOBRE ESSENCIAS NATIVAS, 2, 1992. Anais.

CATHARINO, E. L. M. Floristica de Matas Ciliares. In: SIMPÓSIO SOBRE MATA CILIAR, São Paulo, 1989. Anais. Campinas: Fundação Cargill, 1989. p. 61-70.

CAUBET, C. G.; FRANK, B. Manejo Ambiental em Bacia Hidrográfica: o caso do rio Benedito (projeto Itajaí I): Das reflexões teóricas às necessidades concretas. Florianópolis: Fundação Água Viva, 1993. 52p. 
CHAMBERS, R.; RICHARDS, P.; BOX, L. Agricultores Experimentadores e Pesquisa. Rio de Janeiro: AS-PTAFASE, 1989. 44 p. (AS-PTAFASE, Agricultores na Pesquisa, 1)

CONSORCIO INTERMUNICIPAL DAS BACIAS DOS RIOS PIRACICABA E CAPIVARI/ DAEE/ FUNDAP. Semana de Debates sobre Recursos Hidricos e Meio Ambiente. Piracicaba: Atas, 1992. 200 p. (Consórcio Intermunicipal $\left.n^{\circ} 8\right)$.

CONSORCIO INTERMUNICIPAL DAS BACIAS DOS RIOS PIRACICABA E CAPIVARI. Estatuto. Revisto e contendo: Participação de Empresas e Apoio aos Sistemas de Gerenciamento de Bacias. Americana: Consórcio Intermunicipal, 1996. 13p. (Consórcio Intermunicipal n¹4).

CONSÓRCIO INTERMUNICIPAL DAS BACIAS DOS RIOS PIRACICABA E CAPIVARI. Convênio CESPI Consórcio Piracicaba - Capivari: resumo das atividades 1989 - 1996; plano de atuação da gestão 1997 - 1998. Consórcio Intermunicipal das Bacias dos rios Piracicaba e Capivari. São Paulo: CESP, 1998. 33p.

CRESTANA, M. de S. M.; BOVI, J. E.; BOSQUILIA, S. V. Microbacia hidrográfica do Ribeirão Cachoeirinha - Iracemápolis/SP. In: Consórcio Intermunicipal das Bacias dos Rios Piracicaba e Capivari, DAEE, FUNDAP. Semana de Debates sobre Recursos Hidricos e Meio Ambiente. Piracicaba: Ed. Atas, 1992. 200 p. p.145-157.

DELITTI, W. B. C. Ciclagem de Nutrientes Minerais em Matas Ciliares. In: SIMPÓSIO SOBRE MATA CILIAR, São Paulo, 1989. Anais. Campinas: Fundação Cargill, 1989. p. 88-98. 
DEMO, P. Pesquisa e Construção de Conhecimento: metodologia cientifica no caminho de Habermas. Rio de Janeiro: Ed. Tempo Brasileiro, 1994. 125p.

EDWARDS, R. J. A. Monitoramento de sistemas agricolas como forma de experimentação com agricultores. Trad. de John Cunha Comerford. Rio de Janeiro: AS-PTAFASE, 1993. 25 p. (AS-PTAFASE, Agricultores na Pesquisa, 5)

FREIRE, P. Criando métodos de pesquisa alternativa: aprendendo a fazé-la melhor através da ação. In: BRANDĀO, C. R. (org.). Pesquisa Participante. São Paulo: Brasiliense, 1982. 211 p.

FREIRE, P. Extensão ou Comunicação? $7^{\circ}$ edição. Rio de Janeiro: Paz e Terra, 1983. $93 \mathrm{p}$.

GALJART, B. Difusão cultural, modernização e subdesenvolvimento. In: QUEDA, O.; SZMRECSÁNYI, T. (orgs). Vida Rural e Mudança Social: leituras básicas de sociologia rural. São Paulo: Ed. Nacional, 1972. Cap.5, p. 70-79.

GÖSCH, E. Homem e Natureza: cultura na agricultura. Recife: Centro de Desenvolvimento Agroecológico SABIÁ, 1995. 19 p.

GRAZIANO DA SILVA, J. A Nova Dinâmica da Agricultura Brasileira. Campinas: UNICAMP/IE, 1996. 217 p. 
IBAMA. Educação ambiental: as grandes orientaçōes da Conferência de Tbilisi / organizado pela UNESCO. Brasília: Instituto Brasileiro do Meio Ambiente e dos Recursos Naturais Renováveis, 1997. 154p. (Coleçăo meio ambiente. Série estudos educaçăo ambiental; edição especial)

KAGEYAMA, P. Y.; CASTRO, C. F. A.; CARPANEZZI, A. A. Implantação de Matas Ciliares: estratégias para auxiliar a sucessão secundária. In: SIMPÓSIO SOBRE MATA CILIAR, São Paulo, 1989. Anais. Campinas: Fundação Cargill, 1989. p.130-143.

KAGEYAMA, P. Y. Conservação "In Situ" de Recursos Genéticos de Plantas. In: Instituto de Pesquisas e Estudos Florestais/ ESALQ/ USP. Piracicaba: IPEF, (35), 1997. p.07-37.

LEIS, H. R. O Labirinto: ensaios sobre ambientalismo e globalizaçăo. São Paulo: Gaia / Blumenau: Fundação Universidade de Blumenau, 1996. 171 p.

LIMA, W. de P. Função Hidrológica da Mata Ciliar. In: SIMPÓSIO SOBRE MATA CILIAR, São Paulo, 1989. Anais. Campinas: Fundação Cargill, 1989. p. 25-42.

MACEDO, A. C. Revegetação: matas ciliares e de proteção ambiental (revisado e ampliado por Paulo Y. Kageyama, Luiz G. S. Costa. São Paulo: Fundação Florestal, 1993. 27p. 
MACHADO, M. L. da S.; RODRIGUES, A. dos S. A Geraçăo de Tecnologia e os Desafios para a Agricultura Familiar na Nova Conjuntura Econômica. In: XXXIII CONGRESSO BRASILEIRO DE ECONOMIA E SOCIOLOGIA RURAL "POLITICA AGRICOLA E ABERTURA DE MERCADO", Curitiba, 1995. Anais. Curitiba: SOBER, 1995. p. 1294-1307.

MANTOVANI, W. Dinåmica das Populaçōes. In: SIMPÓSIO SOBRE MATA CILIAR, São Paulo, 1989. Anais. Campinas: Fundação Cargill, 1989. p. 120-129.

MCCORMICK, J. Rumo ao paraíso: a história do movimento ambientalista. Trad. de Marco Antonio Esteves da Rocha e Renato Aguiar. Rio de Janeiro: Relume-Dumará, 1992. 224p.

MICHAELIS: moderno dicionário da língua portuguesa. São Paulo: Companhia Melhoramentos, 1998. (Dicionários Michaelis).

MILZ, J. Guía para el Estabelecimiento de Sistemas Agroforestales: en Alto Beni, Yucumo y Rurrenabaque. La Paz: Servicio Aleman de Cooperacion Social-Tecnica (DED), 1997. 92 p.

MINC, C. Como fazer movimento ecológico: e defender a natureza e as liberdades. Petrópolis: Vozes/IBASE, 1985. 100p. (Coleção fazer)

MONTICELLI, J. J.; BARROS, F. G. de. Plano de atuação e orçamento para 1991. MONTICELLI, J. J. (coord.). São Paulo: Édile - Serviços Gráficos e Editora Ltda, 1991. 32p. (Consórcio Intermunicipal das Bacias dos rios Piracicaba e Capivari, $n^{\circ} 4$ ) 
MONTICELLI, J. J.; BARROS, F. G. de. Plano de atuação e orçamento - 1992. MONTICELLI, J. J. (coord.). Americana: Consórcio Intermunicipal das Bacias dos rios Piracicaba e Capivari, 1992. 26p. (Consórcio Intermunicipal das Bacias dos rios Piracicaba e Capivari, $n^{\circ} 7$ )

MONTICELLI, J. J.; LAHÓZ, F. C. C; MUNIZ, M. I. S.; BRAGA, A. R. Semana da Água: um programa de educação ambiental para crianças e adultos. São Paulo: Consórcio Intermunicipal das Bacias dos Rios Piracicaba e Capivari. 1996. 36 p.

MORAIS, W. V.; DE PAIVA, M. D. Projeto de educação ambiental com os proprietários rurais confrontantes com o Parque Nacional do Caparaó. In: Congresso Nacional sobre Essências Nativas, $2^{\circ}$, Piracicaba, 1992. Anais. $1153-1156$.

MÜLLER, A. C.; ZELAZOWSKY, V. H.; CARBONAR, F. J. S. Programa de Reflorestamento da mata ciliar do reservatório da Itaipú Binacional. In: Congresso Florestal Brasileiro, $6^{\circ}$, Campos do Jordão, 1990. Anais. p. 243248.

NADOLNY, M. C.; CONTAR, A. Reposição de matas ciliares no norte do Paraná. In: CONGRESSO FLORESTAL BRASILEIRO, 6, Campos do Jordão, 1990. Anais. p.268-274.

NILSSON, T. T. Levantamento do Potencial Económico da Mata Ciliar e Sugestóes quanto ao seu Aproveitamento Racional. In: SIMPÓSIO SOBRE MATA CILIAR, São Paulo, 1989. Anais. Campinas: Fundação Cargill, 1989. p. 144-155. 
QUEDA, O. A Extensão Rural no Brasil: da Anunciação ao Milagre da Modernizaçăo Agrícola. Tese de Livre Docência, USP/ESALQ, 1987.

REICHARDT, K. Relações Agua-Solo-Planta em Mata Ciliar. In: SIMPÓSIO SOBRE MATA CILIAR, São Paulo, 1989. Anais. Campinas: Fundação Cargill, 1989. p. 20-24.

REIJNTJES, C.; HAVERKORT, B.; WATERS-BAYER, A. Agricultura para o Futuro: uma introdução à agricultura sustentável e de baixo uso de insumos externos. Trad.: John Cunha Comerford. Rio de Janeiro, ASPTAILEA-ETC, 1994. $324 \mathrm{p}$.

RESENDE, J. V. de. Paraná sabe conservar a terra. Suplemento Agrícola - 0 Estado de São Paulo, G12-G13, 28 de agosto de 1996.

RICARDO, E. do P.; ROMANI, S. M. A. Programa de Proteção aos Mananciais de Abastecimento Público nas Bacias dos Rios Piracicba e Capivari. In: Consórcio Intermunicipal das Bacias dos Rios Piracicaba e Capivari, DAEE, FUNDAP. Semana de Debates sobre Recursos Hídricos e Meio Ambiente. Piracicaba: Ed. Atas, 1992. 200 p. p. 135-143.

ROCHA, S. C.; SABINO, E. M. G.; FERRAZ, K. M. de A. et al. Normas para elaboração de dissertações e teses. 2.ed. Piracicaba: ESALQ, 1997. 94 p.

SÃO PAULO (Estado). Secretaria do Meio Ambiente. Coordenadoria de Planejamento Ambiental. Bacia do Rio Piracicaba: estabelecimento de metas ambientais e reenquadramento dos corpos d'água. São Paulo, 1994. $81 \mathrm{p}$. 
SÃO PAULO (Estado). Secretaria do Agricultura e Abastecimento. Coordenadoria de Assistência Técnica Integral. Plano de Manejo da Bacia Hidrografica do Forquilha. Capivari: 1990. 18p.

SCHĂFFER, W. B.; PROCHNOW, M; HOFFMANN, A. J. Revista 10 anos APREMAVI. Rio do Sul (SC): Ed. especial. Associaçăo de Preservaçăo do Meio Ambiente do Alto Vale do Itajal, 1997.

SEBASTIANES, J. A. M. Histórico das Campanhas e Lutas pela Despoluiçăo do Rio Piracicaba. In: Consórcio Intermunicipal das Bacias dos Rios Piracicaba e Capivari, DAEE, FUNDAP. Semana de Debates sobre Recursos Hídricos e Meio Ambiente. Piracicaba: Ed. Atas, 1992. 200 p. p. $1-2$.

SCHARF, R. Paulistas descumprem lei de reflorestamento. Gazeta Mercantil, Săo Paulo, 12/01/98. A4.

SILVA, W. C. L. A oposiçăo chamada vida: a PROESP - Campinas e o movimento ecológico no Brasil (1974-1989). In: NEPAN. Ambiente e Sociedade: possibilidades e perspectivas de pesquisas. Campinas: UNICAMP, 1992. 212p.

SIMPÓSIO SOBRE MATA CILIAR, Săo Paulo, 1989. Anais. Campinas: Fundaçăo Cargill, 1989. 335p.

TABANEZ, A. A. J. Ecologia e Manejo de Ecounidades em um Fragmento Florestal na Regiăo de Piracicaba, SP. Piracicaba, 1995. Dissertaçăo (mestrado) - Escola Superior de Agricultura "Luiz de Queiroz"/Universidade de São Paulo. 
THIOLLENT, M. Notas para o debate sobre pesquisa-açăo. In: BRANDÃO, C. R. (org.). Repensando a Pesquisa Participante. Săo Paulo: Brasiliense, 1984. 252p.

VIANA, V. M. Biologia e Manejo de Fragmentos de Florestas Naturais. In: Congresso Florestal Brasileiro, $6^{\circ}$, Campos do Jordăo, 1990. Anais. p.113118.

VITOR, M. A. M.; SERRA FILHO, E. R.; CAVALLI, A. C.; GUILLAUMON, A. C. A devastaçăo florestal. Săo Paulo: SBS, 1975. 


\section{Bibliografia Consultada}

AB'SABER, A. N. (Re)Conceituando Educação Ambiental. Rio de Janeiro: CNPq/ MAST, 1991. (pág. única)

ASSESSOARIASSOCIATIVISMO/SPEP. Estratégias de Conhecimento para o desenvolvimento sustentável na agricultura familiar: formação de monitores para associaçōes (sistematização). DAVID, A. de; DUARTE, V. (org). Rev. de Lidair Tochetto. ljuí: Ed. UNIJUI, 1995. 56p. (Coleção Cadernos UNIJUI)

BRANCO, S. M. Poluição: a morte de nossos rios. $2^{\text {a }}$ edição. São paulo: ASCETESB, 1983. $166 \mathrm{p}$.

BUNCH, R. Duas espigas de milho: uma proposta de desenvolvimento agrícola participativo. Trad. de John Cunha Comerford. Rio de Janeiro: AS-PTA, 1994. 221p.

CHAMBERS, R. Diagnóstico Rápido e Diagnóstico Participativo de Sistemas Rurais. Trad. de Joselita Wasniewski.

DIESEL, V. A educação e a degradação ambiental no meio rural - uma abordagem crítica sobre a eficácia de programas educacionais na preservação da qualidade ambiental. Santa Maria, $1988.281 p$. Dissertação (mestrado) - Universidade Federal de Santa Maria (RS).

D'INCAO, M. C.; ROY, G. Nós, cidadãos: aprendendo e ensinando a democracia. Rio de Janeiro: Paz e Terra, 1995. 279p. 
DUFUMIER, M. A pesquisa para o desenvolvimento - o papel dos diagnósticos nos projetos de desenvolvimento rural.

FREIRE, P. Pedagogia da Autonomia: saberes necessários à prática educativa. São Paulo: Paz e Terra, 1996. 165 p.

GADOTTI, M. Ecopedagogia: Pedagogia para o Desenvolvimento Sustentável. São Paulo: Instituto Paulo Freire, 1996. 13p.

GRAZIANO DA SILVA, J. O Novo Rural Brasileiro. In: SHIKI, S.; GRAZIANO DA SILVA, J.; ORTEGA, A. C. (orgs). Agricultura, Meio Ambiente e Sustentabilidade do Cerrado Brasileiro. Uberlândia: UNICAMP/EMBRAPAUFU, 1997. 372p.

GRÜN, M. Ética e Educação Ambiental: a conexão necessária. Campinas: Papirus, 1996. 120 p. (Coleção Magistério: Formação e Trabalho Pedagógico)

KURT, H. Diagnóstico rápido e participativo da pequena produção rural: como fazer. Recife: SACTES/Centro Sabiá, 1995. 72p. (Série Metodologias Participativas, $n^{\circ} 2$ )

NÚCLEO DE ESTUDOS E PESQUISAS AMBIENTAIS. A Questão Ambiental: cenários de pesquisa: A experiência do Ciclo de Seminários do NEPAN. Campinas: UNICAMP, 1995. 334 p. (Textos NEPAN. Série "Divulgação Acadêmica, 3)

PACHECO, M. E. L. Além da Questão da Terra. In: PROPOSTA: Experiências em Educação Popular. Lavradores em luta por sua sobrevivência: Projetos económicos de produção, comercialização e consumo. Rio de 
Janeiro: Federaçăo de Órgáos para Assistência Social e Educacional, 1986. p.47-56. $\left(n^{\circ} 31\right)$

TASSARA, E. T. de O. Educaçāo Ambiental: conhecimento e política no contexto da "crise ambiental". In: FÓRUM DE EDUCAÇÅO AMBIENTAL, 3․, Săo Paulo, 1994. Cademos do III Fórum de Educação Ambiental. Săo Paulo: GAIAECOAR, 1995. p.39-43.

VEIGA-NETO, A. J. Ciência, Ética e Educaçăo Ambiental em um Cenário PósModerno. In: Educaçăo e Realidade. Ética e Educação Ambiental. Porto Alegre: Faculdade de Educaçăo da Universidade Federal do Rio Grande do Sul, 1994. p.142-169. 